IMF Country Reports $\quad 99 / 15$

Chile: Selected Issues

INTERNATIONAL MONETARY FUND 
March 1999

IMF Staff Country Report No. 99/15

\section{Chile: Selected Issues}

This Selected Issues report on Chile was prepared by a staff team of the International Monetary Fund as background documentation for the periodic consultation with this member country. As such, the views expressed in this document are those of the staff team and do not necessarily reflect the views of the Government of Chile or the Executive Board of the IMF.

Copies of this report are available to the public from

International Monetary Fund • Publication Services

700 19th Street, N.W. • Washington, D.C. 20431

Telephone: (202) 623-7430 - Telefax: (202) 623-7201

Telex (RCA): 248331 IMF UR

E-mail: publications@imf.org

Internet: http://www.imf.org

Price: $\$ 15.00$ a copy

\section{International Monetary Fund Washington, D.C.}




\section{INTERNATIONAL MONETARY FUND}

\section{CHILE}

\section{Selected Issues}

Prepared by S. Lizondo (Head), M. Kaufman, F. Nadal-De Simone (both WHD), P. Sorsa (PDR) and A. Spilimbergo (RES).

Approved by the Western Hemisphere Department

January 13, 1999

Contents

Page

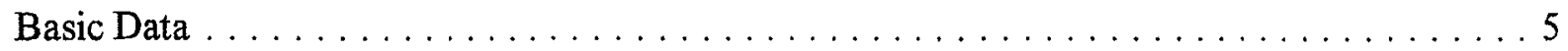

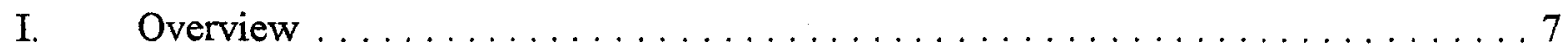

II. $\quad$ Copper and the Chilean Economy $\ldots \ldots \ldots \ldots \ldots \ldots \ldots \ldots$

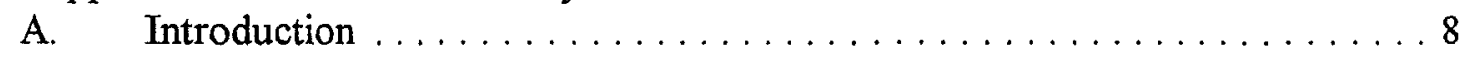

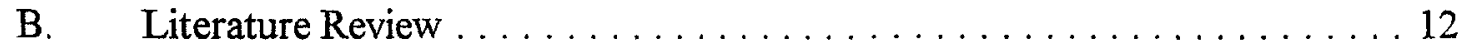

C. Short Run Perspective: Copper Cycle and the Chilean Business Cycle . . . . 13

D. Long Run Perspective: Copper Trends and the Chilean Economy ........ 18

E. Transmission Channels _.................................. 21

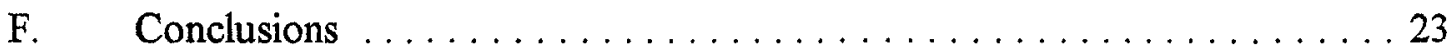

III. Nonrenewable Resources: A Case for Persistent Fiscal Surpluses ............ 40

A. Introduction ................................................... 40

B. A Stylized Model of Fiscal Policy with Nonrenewable Resources _...... 42

C. Conclusion and Policy Implications . . . . . . . . . . . . . . . . . . . . . 44

IV. Capital Account Restrictions in Chile in the 1990s _.............67

A. The Problem ...................................67

B. Evolution of Capital Account Restrictions in Chile in the 1990s _....... 70

C. A Survey of the Literature on the URR in Chile $\ldots \ldots \ldots \ldots \ldots \ldots . . \ldots 77$

D. Conclusions and Policy Implications _.......................... 92

Text Tables

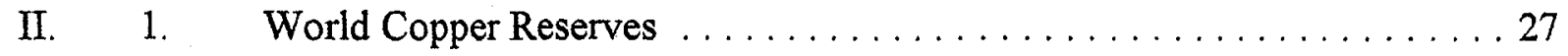

2. World Copper Production by Countries or Regions _.............. 28 
3. Copper Consumption by Countries or Regions _...............29 29

IV. $\quad 1 . \quad$ Evolution of Restrictions on Capital Hlows in the 1990s .............997

2. Summary of Selective Quantitative Studies on the Effects of the URR on Capital Inflows ...................... 99

3. Assessment of Selective Quantitative Studies on the Effects of the URR on Capital Inflows in Chile ................ 100

Figures

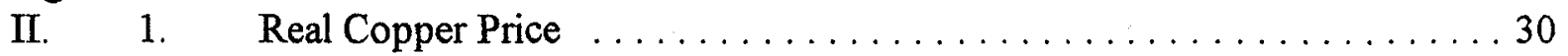

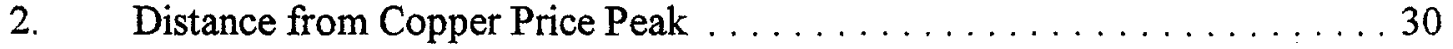

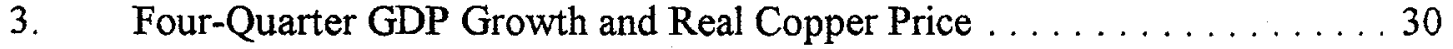

4a. GDP Four-Quarter Growth ___ 3]

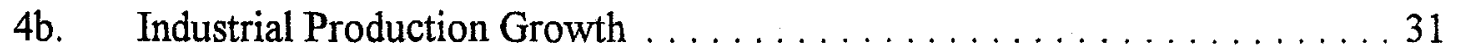

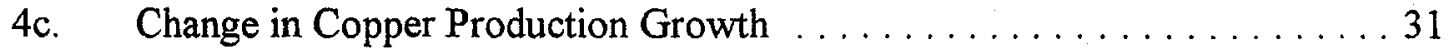

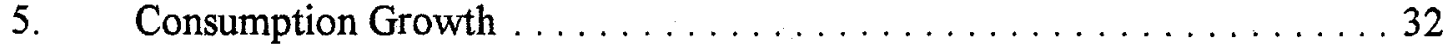

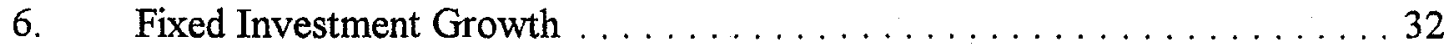

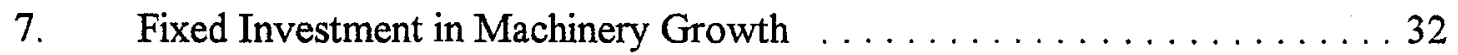

8 . Fixed Investment in Construction Growth _ 33

9. Import Growth _.____ 33

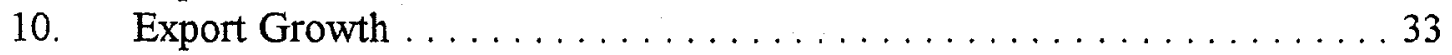

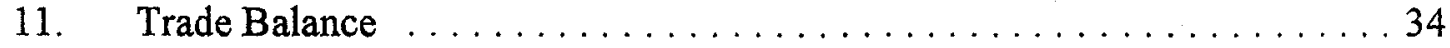

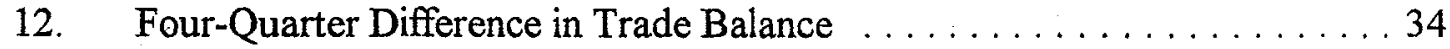

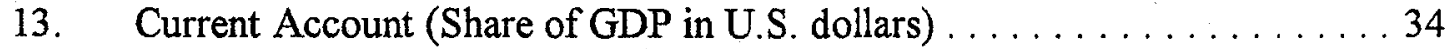

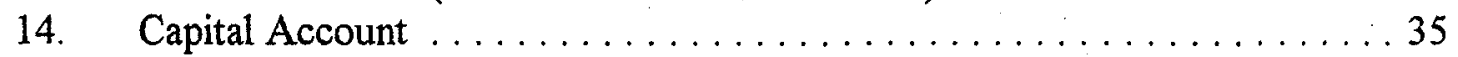

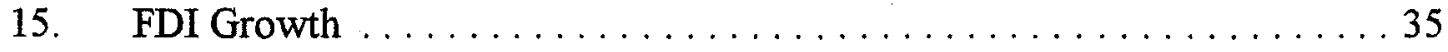

16. Percentage Change in Nominal Exchange Rate _._._._._____. 35

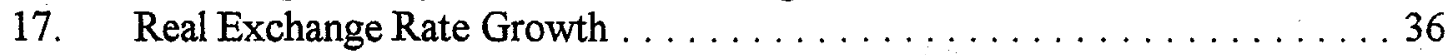

18. Inflation $\ldots \ldots \ldots \ldots, \ldots, \ldots, \ldots, \ldots, \ldots, \ldots, \ldots, \ldots, 36$

19. Real Lending Rate .............................. 36

20 Share Price Growth _..37

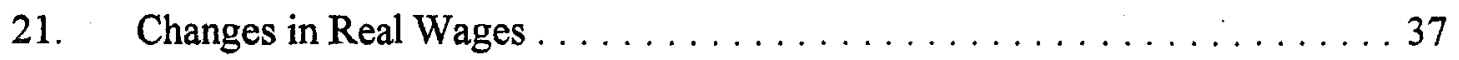

III. 1a. Paths of Primary Deficits (In per capita terms) $\ldots \ldots \ldots \ldots \ldots \ldots \ldots \ldots 49$

Constant Government Expenditure Case _..___________ 49

Increasing Government Expenditure Case _....._.________. 49

Decreasing Government Expenditure Case .............. 49

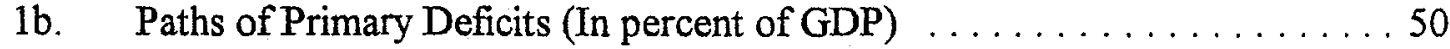

Per Capita-Constant Government Expenditure Case _..........50 50

Per Capita-Increasing Government Expenditure Case $\ldots \ldots \ldots . .50$

Per Capita-Decreasing Government Expenditure Case _ _ 50

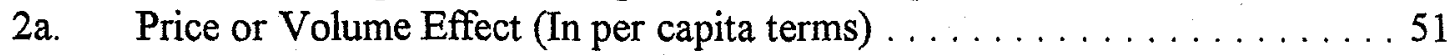

Constant Government Expenditure Case ................ 5]

Double Endowment Size Case $\ldots \ldots \ldots \ldots \ldots \ldots \ldots \ldots \ldots$. 
2h. Price or Volume Effect (In percent of GDP) _._._._._._._._... 52 Per Capita-Constant Government Expenditure Case .......... 52

Double Endowment Size Case ................... 52

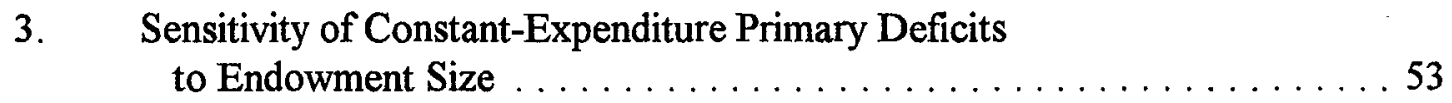

IV. 1. Components of Gross Capital Oufflows in Chile $\ldots \ldots \ldots . .102$

$2 . \quad$ Different Definitions of Capital Inflows . ...................., 102

B. Share of URR-covered Flows in Gross Capital Inflows ........... 103

4. URR Tightening (1991, 1996, 1996) and Behavior of Affected Gross Inflows ......................... 103

5a. Net Short-term Capital Flows (Total, Debt, and Nondebt Flows) . . . . . . 104

5b. Structure of Foreign Capital in Chile ...................... 104

6. Capital Account Ratio to GDP: Trend and Cyclical Components ...... 105

7. Capital Inflow and Outflow Ratios to GDP: Trend and Cyclical Components .............................. 106

8a. Domestic Minus Foreign Real Interest Rates and Changes in the Real Effective Exchange Rate Lagged One Year: Cyclical Components . . . . . . . . . . . . . . . . . . . . . . . . 107

8b. Domestic Minus Foreign Potential Output Growth and Changes in the Real Effective Exchange Rate: Trend Components . . . . 107

9a. Chile: Short-term Capital Flow Ratio to GDP, Trend and Cyclical Components .............................. 108

9b. Brazil: Short-term Capital Flow Ratio to GDP, Trend and Cyclical Components . . . . . . . . . . . . . . . . . . . . . . . . . 108

9c. Mexico: Short-term Capital Flow Ratio to GDP, Trend and Cyclical Components

Boxes

III. 1 . Copper .....................................10

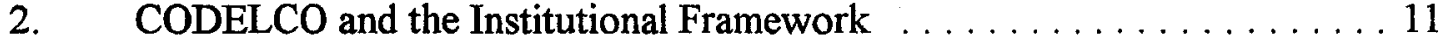

Appendices

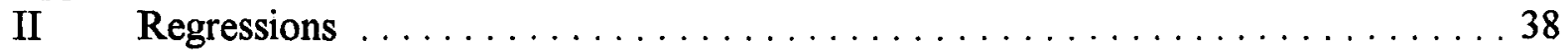

III $\quad 1 \quad$ A Stylized Model of Fiscal Policy with Nonrenewable Resources _._.

2. Initial Conditions for Initial Primary Surpluses $\ldots \ldots \ldots \ldots \ldots \ldots 65$

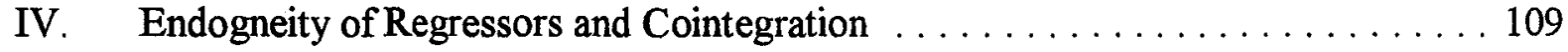


Statistical Appendix Tables

Dutput and Prices

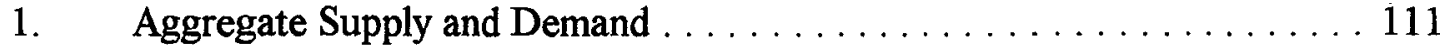

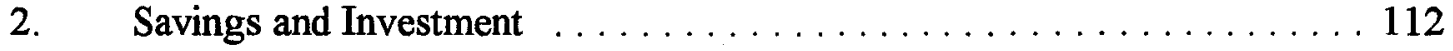

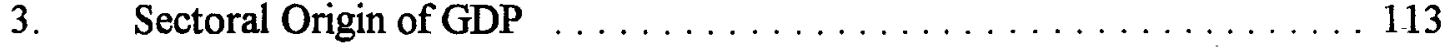

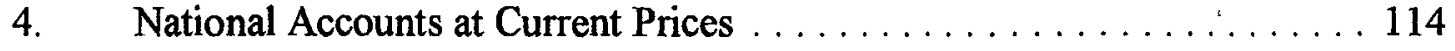

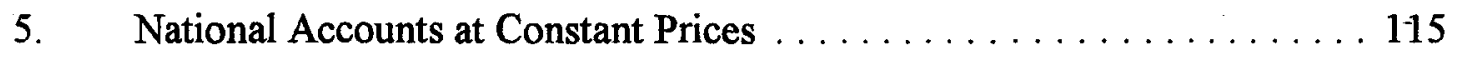

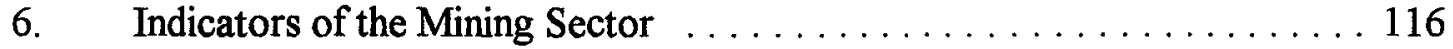

7. Indicators of the Manufacturing Sector $\ldots \ldots \ldots \ldots \ldots \ldots \ldots$

8 . Population, Labor Force, and Employment . . . . . . . . . . . . . 118

Q. Index of Nominal Wages _........................ II

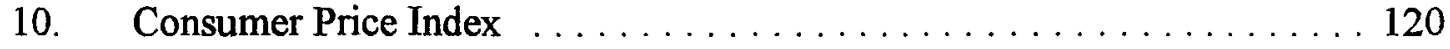

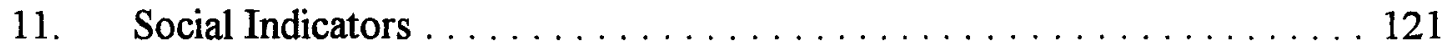

Nonfinancial Public Sector

12. Summary Operations of the Combined Public Sector $\ldots \ldots \ldots \ldots \ldots 122$

113. Summary Operations of the General Government _._._._._._._._. 123

144 General Government Revenue _._._._._._._._._._._._._. 124

15. General Government Expenditure $\ldots \ldots \ldots \ldots \ldots \ldots \ldots \ldots \ldots \ldots$

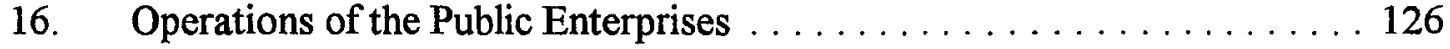

II. Summary Operations of COJELCO

118. Fiscal Impulse .......................... 128

Financial System

19. Real Interest Rates on Central Bank Notes and Operations of the Financial System ... . . . . . . . . . . . . . . . . . . . 129

20. Private Sector Holdings of Financial Assets $\ldots \ldots \ldots \ldots \ldots \ldots \ldots$

$21 . \quad$ Operations of the Financial System $\ldots \ldots \ldots \ldots \ldots \ldots \ldots \ldots$

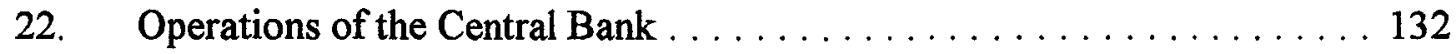

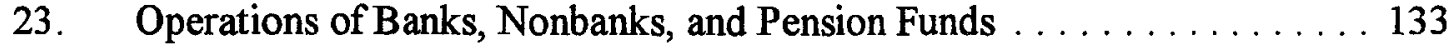

24. Summary Accounts of the Financial System _...................... 134

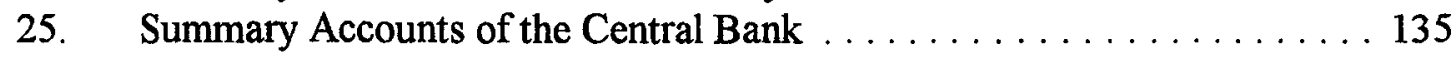

26. Summary Accounts of Banks and Nonbanks Financial Intermediaries _.... 136

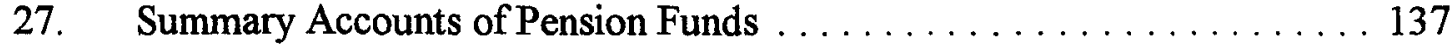

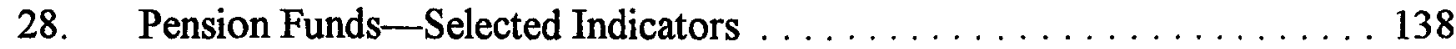

External Sector

29. Export and Import Values, Volumes and Prices, and Terms of Trade _... 139

B0. Exports (f.o.b.) by Main Categories _................... 140

BI. Imports (c.1.f.) by Type of Goods _...................... 14]

B2. Capital Goods Imports .......................... 142

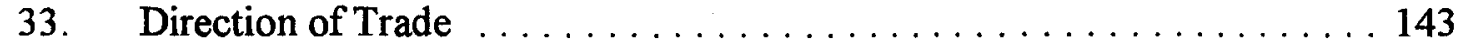

34. Net International Reserves of the Financial System $\ldots \ldots \ldots \ldots \ldots \ldots$ 


\section{Chile: Basic Data}

Area (thousand sq. km.)

Population (1997)

Total (million)

Rate of growth, 1993-97 (percent a year)

Density, 1997 (per sq. km. of agricultural land)

GDP per capita, 1997 (US\$)

Population characteristics

Life expectancy at birth, 1995 (years)

Infant mortality rate, 1995 (per thousand)
I. Social and Demographic Indicators

757

14.6
1.5
88.3
5,255

74.8
11.1

Nutrition (1988)
Calorie intake

(per capita a day)

2,544

Health

Population per physician (1992) 2,152

Population per hospital bed (1994) 325

Access to safe water

Percent of population (1992) 87

Education

Primary school enrollment rate (1996), $\quad 98.2$

Adult literacy rate (1995) $\quad 95.37$

II. Economic Indicators, 1993-98

\begin{tabular}{|c|c|c|c|c|c|c|}
\hline & 1993 & 1994 & 1995 & 1996 & 1997 & $\begin{array}{l}\text { Proj. } \\
1998 \\
\end{array}$ \\
\hline \multicolumn{7}{|c|}{ (In annual percent changes) } \\
\hline \multicolumn{7}{|l|}{ National accounts and prices } \\
\hline GDP (in constant prices) & 7.0 & 5.7 & 10.6 & 7.4 & 7.1 & 4.5 \\
\hline Agriculture, forestry, and fishing & 8.4 & 8.6 & 8.3 & 8.1 & 7.5 & $\ldots$ \\
\hline Mining and quarrying & 7.6 & 7.9 & 7.8 & 8.3 & 8.2 & $\ldots$ \\
\hline Manufacturing & 17.0 & 16.7 & 16.2 & 15.8 & 15.3 & $\ldots$ \\
\hline Construction & 5.6 & 5.3 & 5.2 & 5.4 & 5.3 & $\cdots$ \\
\hline Commerce & 16.2 & 16.1 & 16.7 & 17.2 & 17.2 & $\ldots$ \\
\hline Transport, storage, communications & 7.4 & 7.4 & 7.6 & 7.9 & 8.3 & $\cdots$ \\
\hline Other & 37.7 & 38.1 & 38.2 & 37.3 & 38.3 & $\cdots$ \\
\hline Consumer prices (end of period) & 12.2 & 8.9 & 8.2 & 6.6 & 6.0 & 4.5 \\
\hline \multicolumn{7}{|c|}{ (In percent of GDP) } \\
\hline Gross domestic investment & 26.5 & 24.1 & 25.8 & 26.6 & 26.9 & 27.1 \\
\hline Gross national savings & 20.8 & 21.0 & 23.6 & 21.2 & 21.6 & 20.3 \\
\hline \multicolumn{7}{|c|}{ (In billions of Chilean pesos) } \\
\hline \multicolumn{7}{|l|}{ General government finances } \\
\hline Revenues & $4,512.0$ & $7,313.8$ & $8,488.2$ & $9,287.0$ & $10,142.5$ & $10,516.3$ \\
\hline Expenditures & $4,202.4$ & $6,806.1$ & $7,540.0$ & $8,687.4$ & $9,813.7$ & $10,627.8$ \\
\hline Current expenditure & $3,364.0$ & $3,866.6$ & $4,472.8$ & $5,087.5$ & $5,696.8$ & $6,308.8$ \\
\hline Current account surplus or deficit $(-)$ & 822.4 & $1,101.7$ & $1,710.1$ & $1,724.7$ & $1,806.7$ & $1,437.6$ \\
\hline Overall surplus or deficit (-) & 309.6 & 507.7 & 948.2 & 599.6 & 328.7 & -111.5 \\
\hline \multicolumn{7}{|l|}{ Memorandum item: } \\
\hline $\begin{array}{l}\text { Combined public sector overall surplus } \\
\text { or deficit } 1 / \text { (percent of GDP) }\end{array}$ & 0.7 & 1.3 & 3.1 & 1.4 & 0.1 & -1.2 \\
\hline \multicolumn{7}{|c|}{ (In annual percent changes) } \\
\hline Money & 20.6 & 20.6 & 23.5 & 10.5 & 16.6 & -4.1 \\
\hline Quasi-money & 29.6 & 18.8 & 28.9 & 26.2 & 11.9 & 7.8 \\
\hline Net domestic assets of financial system $2 /$ & 30.8 & 15.1 & 16.7 & 11.5 & 7.9 & 8.5 \\
\hline Credit to nonfinancial public sector (net) & -0.3 & -1.9 & -1.9 & -0.2 & -2.0 & 1.6 \\
\hline Credit to private sector & 28.1 & 16.4 & 18.0 & 12.6 & 11.7 & 3.6 \\
\hline
\end{tabular}


$-6-$

Chile: Basic Data (concluded)

II. Economic Indicators, 1993-98

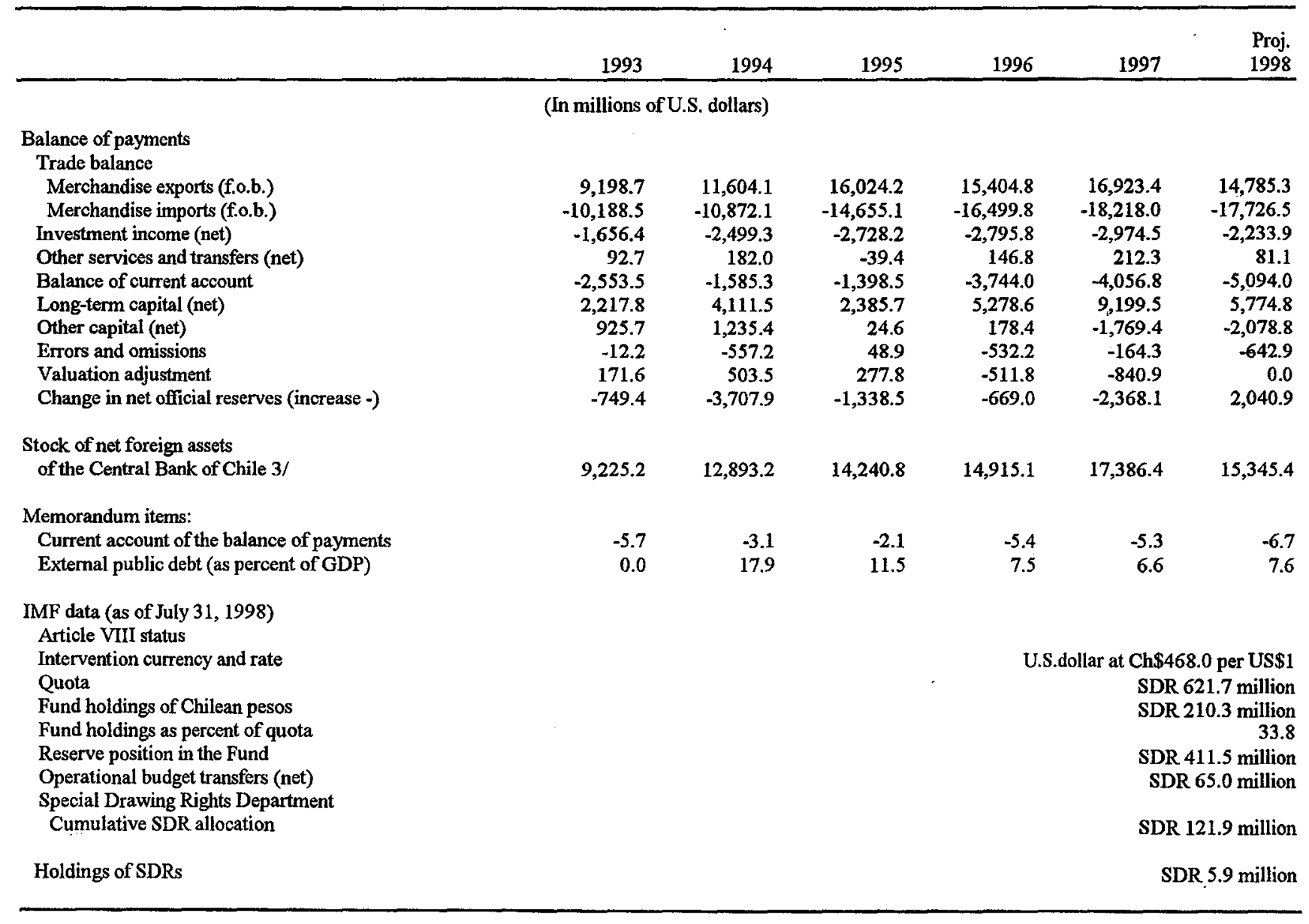

1/ Includes central bank losses.

$2 /$ Changes as percent of liabilities to the private sector at the beginning of the period. Flows based on end-of-period exchange rates.

$3 /$ Gold valued at US\$42.22 per ounce. 


\section{OVERVIEW}

1. This paper contains three chapters and a statistical appendix. The first two chapters discuss the role of copper, a nonrenewable natural resource, in the Chilean economy from the viewpoint of its impact on Chile's business cycle and the government's fiscal balance. The third chapter examines Chile's experience with capital account restrictions in the 1990s.

2. The chapter "Copper and the Chilean Economy, 1960-98" studies the links between world copper prices and the Chilean economy in the short run and the long run using both graphical illustration and statistical analysis. The main conclusion is that world copper prices play an important role in short-term fluctuations and probably influence long-term growth. While many mechanisms may be at work, investment seems to play a major role. In a copper price boom, the higher copper price and associated capital inflows create upward pressure on the real exchange rate, which partially offsets the positive effects of the higher copper price on the current account. The appreciation of the Chilean peso during the first part of the copper cycle also contributes to lower inflation which, in the presence of backward-looking wage indexation, could partly explain why real wages grow more rapidly in this part of the cycle.

3. The chapter "Nonrenewable Resources: A Case for Persistent Fiscal Surpluses" addresses a general question: is there a case for temporary but persistent fiscal surpluses in economies, like Chile, heavily endowed with nonrenewable resources? The answer is that this is generally the case. If the government cares for the welfare of future generations, it will have incentives to save at least part of the revenues derived from the exploitation of an exhaustible resource by running fiscal surpluses. This will permit the replacement of nonfinancial wealth with financial assets, the return on which can be used to increase the consumption possibilities of future generations. The size of the initial surpluses is determined by the government's relative time-preference and the size of the finite endowment. The discussion in this chapter is based on a stylized model, subject as usual to many caveats, and intends only to highlight the intergenerational considerations that would be important to take into account when analyzing fiscal policy from a long-term perspective.

4. The chapter "Capital Account Restrictions in Chile in the 1990s" examines the Chilean experience with controls on capital flows and reviews a number of studies on controls on capital inflows. It seems that controls on capital inflows induced agents to try to avoid them to some extent via substituting untaxed transactions for taxed transactions. The reviewed studies suggest that controls on capital inflows have increased domestic real interest rates above the level that they would have had otherwise, and may have reduced short-term capital inflows, but they have had no significant effect on the magnitude of total net capital inflows or on the level of the real exchange rate. However, the studies suffer from methodological and econometric problems. Also, they have not controlled for a number of factors such as the liberalization of capital outflows during the 1990s, the effect of sterilization operations on domestic interest rates, and foreigners' willingness to lend. These problems may have biased the estimates either in favor or against the hypothesis that these controls were effective. 


\section{COPPER AND THE CHILEAN ECONOMY, 1960-981}

\section{SUMMARY}

This paper examines the links between the behavior of the world copper price and the Chilean economy in the short run and the long run. The analysis is tailored to the available data (quarterly data between 1986 and 1998, and annual data between 1960 and 1997). Case-by-case and graphic illustration are used for the short-run analysis of copper price cycles and Chilean business cycles, and statistical analysis is applied to the long-run review of copper exports and macroeconomic variables. The analysis focuses on three clear copper prices cycles that peaked in 1989:Q1, 1993:Q3, and 1997:Q3.

The main conclusion of this study is that world copper prices play an important role in shortterm fluctuations and probably influence long-term growth. While many mechanisms may be at work, investment seems to play a major role. In the presence of rising copper prices, both domestic and foreign agents increase investment in Chile. However, in a copper price boom, the higher copper price and associated capital inflows create upward pressure on the real exchange rate, which partially offsets the positive effects of the higher copper price on the current account.

The appreciation of the Chilean peso during the first part of the copper cycle also contributes to lower inflation which, in the presence of backward-looking wage indexation, could partly explain why real wages grow more rapidly during the phase of increasing copper prices. In turn, higher real wages favor higher consumption, which typically peaks two or three quarters after the peak in the price of copper. However, unlike other countries with a large endowment of natural resources, in Chile there is only limited evidence of consumption booms caused directly by the copper cycle.

\section{A. Introduction}

5. Chile has experienced very strong growth in the last decade, but copper continues to have a major role in the economy. The purpose of this paper is to examine the dynamic

${ }^{1}$ Prepared by Antonio Spilimbergo (RES). The author thanks Pablo Cabezas, Nicolás Eyzaguirre, Martine Guerguil, Esteban Jadresic, Martin Kaufman, Francisco Nadal-De Simone, Piritta Sorsa, Peter Wickham and especially Saul Lizondo; the author also thanks Chilean officials for comments on a preliminary draft of this paper. 
relationships between the copper price cycle, the Chilean business cycle, and the various GDP components in the country's economy. ${ }^{2}$

6. The Chilean economy is very dependent on copper according to several measures. In terms of exports, copper accounted for 42 percent in 1997, while the mining sector, which includes other minerals, accounted for 50 percent. In terms of GDP, the mining sector accounted for 8 percent in $1997 .^{3}$ In terms of fiscal revenues, CODELCO, which is the state company that manages the public copper mines (see Box 2), contributed 3.6 percentage points of GDP in 1997, representing more than 10 percent of the central government's revenues. ${ }^{4}$

7. While such a high dependency on a natural resource is common to other countries, a singular characteristic of Chile is that both the mining sector and the rest of the economy have grown at roughly the same pace over the last decade, even though Chile's GDP has grown at an average annual rate of 8 percent during that period. ${ }^{5}$ This fact is surprising given the slightly different reasons behind growth of the mining sector and that in the rest of the Chilean economy. The mining sector grew because of the rapid expansion of production (an increment of more than 130 percent from 1988 to 1997) due to massive capital inflows, while the other sectors of the economy expanded in response to profound structural reforms and a stable macroeconomic environment.

8. The massive investment in the copper sector of recent years, and the large reserves of copper ( 28 percent of the world's proven and economically viable reserves are in Chile) indicate that copper will remain very important in the Chilean economy in the future. This has prompted a debate on several aspects of copper exploitation. This paper focuses on the positive aspects of the behavior of the Chilean economy in relation to copper. Other aspects, such as the optimal policies in the exploitation of natural resources, are not considered here even though they may be very important.

${ }^{2}$ Box 1 , and Tables 1 to 3 provide an overview of the world copper market and of Chile's relative position in that market.

${ }^{3}$ The real importance of the copper sector is probably underestimated given that many industrial activities are related to the mining sector.

${ }^{4}$ These and several following figures are taken from the CODELCO statistical bulletin and do not correspond necessarily to the data in the Staff Report for the 1998 Article IV Consultation with Chile.

${ }^{5}$ Copper accounted for 42 percent of Chilean exports in 1986, which is the same share as in 1997. Also, considering the mining sector overall, the share of exports was 50 percent in 1986 , and is the same in 1997. In terms of GDP, the mining sector declined steadily from 10 percent in 1986 to 8 percent in 1997. 


\section{Box 1. Copper}

Copper is an important input in a wide range of industries due to its thermal and electrical conductivity. It is used in the construction industry as wire and tubing for plumbing and air conditioning, in manufacturing to build electronic equipment and in the automotive industry for electrical equipment, and in telecommunications to build copper cables.

Almost half of the world's known reserves of copper are concentrated in two countries (Table 1): Chile accounts for 28 percent of the reserves, while the United States accounts for 17 percent. Other individual countries have considerably fewer reserves. The distribution of copper production is even more concentrated, with Chile producing 34 percent of the world output, and United States 17 percent.

World demand for copper presents wide regional variation over time (Table 3). Despite declining shares, North America and Western Europe remain the biggest users of copper with a combined share of 59 percent of world demand. Given the extensive use of copper in the construction, light automotive, and telecommunication industries, an increasing share of copper is used in newly industrialized economies. Asia, excluding Japan, increased its world share in consumption of copper from 20 percent in 1992 to 25 percent in 1997, making the region the most dynamic market for copper.

The price of copper is quite volatile because demand and supply are not very sensitive to price changes in the short run. Additionally, Borensztein, et al. (1994) report that commodity prices have become more volatile over the last decade. Formal tests show that the hypothesis of unit root cannot be rejected even with large critical values.

The long-term prospects for copper production are good. Copper's particular physical characteristics, make it appealing in a wide range of applications, and the substitution of new materials unlikely, although the metal faces increasing competition from optic fibers in the telecommunication industry, and from aluminum in the construction and automotive industries. 


\section{Box 2. CODELCO and the Institutional Framework}

CODELCO (Corporación Nacional del Cobre de Chile) is Chile's state-owned company dedicated to the extracting and selling copper from the state-owned mines. CODELCO is wholly owned by the Chilean government which receives under various forms the company's entire annual profits, which have been around US\$1 billion per year in the 1990s, representing on average 11 percent of Chile's fiscal revenues. CODELCO is also one of the largest economic players in Chile, with US\$873 million invested in 1997. Additionally, CODELCO produces more than 10 percent of the world's copper production.

Before the 1970 s, Chilean copper mines were owned mainly by U.S. multinational companies, such as Anaconda, Kennecott, and Cerro corporation. In 1971 the Chilean congress voted a constitutional reform to nationalize the large mines owned by multinationals. In 1976, the military government created CODELCO to administer the nationalized copper mines (Chuquicamata, El Salvador, Andina, and El Teniente). As a consequence, in the late 1970s the Chilean government had the monopoly over large mines, which accounted for 85 percent of the national copper production.

In 1980, the military government included the public ownership of CODELCO in the constitution and readmitted foreign investment in new large mines. This and the decree on foreign investment enacted in 1974 created the legal framework for foreign investment in the mining sector. Besides the constitutional protection to the right of private ownership of mines, Chile adopted a fiscal regime for mining with no royalty payments and low tax rates on profits, and the possibility of reducing even further the tax burden through accelerated depreciation; this provided strong incentives for investment in mining. Foreign direct investment in the mining sector grew from a yearly average of US\$90 million in the period 1974-89 to US\$803 million in 1990. During the period 1989-95, the mining sector accounted for more than half of foreign direct investment to Chile. ${ }^{1}$ As a result, the share of large private mines ("mediana mineria") rose from 6 percent of output in 1980 to 54 percent in 1996, while the share of CODELCO shrank from 84 to 39 percent over the same period. ${ }^{2}$ The large private investments in mining have pushed CODELCO to develop new projects. In 1996-97, investment by CODELCO almost doubled compared with the previous years in order to open the new mine "Rodomiro Tomic" and to improve productivity in its other mines.

Besides CODELCO ("gran mineria") and the large private companies ("mediana mineria"), there are several small companies ("pequeña mineria") representing about 10 percent of the production, which sell their output to the public enterprise ENAMI for refining and selling in the international market. These small companies have relatively high operational costs and usually stop production when the price of copper falls below a certain level.

1" Starting in 1995, the privatization of utilities and the growth in other industrial investment has reduced the relative importance of the mining sector, so that it accounted for less than one third of foreign investment in 1997.

${ }^{2 /}$ The name "mediana mineria" (medium sized mining) is somewhat misleading because some of the mines included in this category, such as Escondida, are larger than the mines listed in "gran mineria" (large sized mining). The denomination refers to the relative size of the mines at the time of nationalization. Now these categories only describe ownership, with "gran mineria" including the mines owned by CODELCO, and "mediana mineria" including privately-owned companies. 
9. The paper is divided into five sections: the first section contains a brief review of the literature on copper and the Chilean economy, the second section presents some stylized facts on the links between copper and the Chilean business cycles, focusing on the short run, the third section analyzes the long-run relationships between copper exports and macroeconomic variables, the fourth section discusses some possible transmission mechanisms, the fifth section draws some policy conclusions and is followed by a technical appendix.

\section{B. Literature Review}

10. In addition to the vast literature on natural resources and growth, there are some specific studies on copper and Chilean economic policy that consider both long-term and business cycle issues. Papers that focus on the long-term effects of copper include: Morandé and Quiroz (1996), Bande and French-Davis (1989), Romaguera and Contreras (1995), and Moguillansky (1998). Papers that focus on copper and cyclical issues include Calvo and Mendoza (1998).

11. Morandé and Quiroz (1996) consider the long-term effects of the mining sector on the real exchange rate, wages, and fiscal revenues. By analyzing the experience of the early 1990s, they conclude that copper has had a modest effect on the real appreciation of the exchange rate and wages, but negligible effects on inflation. Furthermore, they notice that the mining industry is capital-intensive and that capital is largely imported, so that local resources are not displaced and the possibility of a Dutch disease is very small. Additionally, copper brings considerable resources to Chile's Treasury. The authors conclude that copper is a "fullblessing" and that any "significant intervention by government authorities to try to counterbalance the small negative effects in some sectors would likely bring harmful side effects."

12. Bande and French-Davis (1989) find that copper contributed to the downturns of late 1974 and 1981, while the price upturn of 1987-89 was a determinant for the sharp recovery that took place in that period. They notice that the main objective of public policies on copper between 1973 and 1988 was to expand production and to set up appropriate mechanisms to offset the economy's external vulnerability. They argue that, while the first objective was partially met, the second objective has not been reached because "of the excessive reliance on the market mechanisms to counteract fluctuations of the copper price."

13. Romaguera and Contreras (1995) study the impact of copper in the context of structuralist analysis and conclude that the copper price cycle has had an important effect on Chilean growth in the last 40 years by determining the external and fiscal constraints. They also argue that the huge fluctuations of copper prices have made fiscal revenues and the availability of foreign currency very unstable and have had negative consequences on growth in the long run.

14. Moguillansky (1998) focuses on investment in the mining sector. She argues that the institutional framework (the law on foreign investment (1974) and the law on mining (1980)) 
created the necessary conditions for the increase of copper production in the early 1990s. She also finds evidence that foreign investment in the copper sector has had a positive effect on CODELCO, which invested heavily in the beginning of the 1990 s to maintain efficiency.

15. Calvo and Mendoza (1998) study the effects of copper on Chilean business cycles in the period 1986 to 1997 . They find that the lagged core terms of trade, which are defined as the ratio between the price of copper over the price of oil, Granger-cause IMACEC, which is a monthly indicator of economic activity. Additionally, they find that "after two years about one quarter of the variability in the growth of IMACEC is attributable to the core terms of trade." The authors also present evidence that "changes in the exchange rate and in the performance of the external sector help explain the decline in inflation."

16. Although the papers reviewed use different frameworks (neoclassical or structuralist), different methodologies (time series analysis and case studies), and different periods of analysis, they all reach the conclusion that copper has played a crucial role in the Chilean economy.

\section{Short-Run Perspective: Copper Price Cycle and the Chilean Business Cycle}

17. This section presents evidence on the connection between the copper price cycle and the Chilean business cycle. In the first part, the behavior of Chile's GDP is examined and its main components are compared with the copper price cycles; in the second part, some price variables (such as wages, exchange rates, price of shares) are considered and compared with the copper price cycles. The focus is on the behavior of the economy during the copper cycles, and highlights the peculiarities of each cycle.

18. Figure 1 shows the evolution of the $(\mathrm{log})$ real price of copper in the last 40 years. ${ }^{6}$ Copper prices show a negative trend that started in the mid-1960s and lasted until the mid1980s. Around this trend, copper prices have shown dramatic variability which is typical of a natural resource for which both demand and supply are inelastic to price changes in the short run. Variations around the trends are the focus of this section. The long-term negative trend is discussed in Section D.

19. The short-term analysis focuses on the period after 1986 because official quarterly data on national accounts are available only after 1986, there are relatively few economic structural breaks in this period, and the price of copper does not have a clear trend after 1986. The absence of a trend allows us to focus on short-term fluctuations without worrying about secular movements. Since 1986, copper has had three clear cycles, which peaked in 1989:Q1, 1995:Q3, and 1997:Q3. Over the last decade, the frequency of the cycles seems to have increased, while the period between peaks and troughs has diminished. During the first cycle,

\footnotetext{
${ }^{6}$ The manufacturing export unit value from IFS is used in order to deflate the nominal price of copper.
} 
the price of copper more than doubled in two years, and then halved to its original level in the following four years; during the second cycle, the copper price rose by 60 percent in seven quarters, and halved in one year; in the last cycle it rose by 40 percent in one year, to go back to its original level in less than one year. Figure 2 shows the behavior of the log of the real copper price during the three cycles, and a summary line showing the "average cycle." The lines are centered with the respect to the horizontal axis so that the peaks of the cycles (1989:Q1, 1995:Q3, and 1997:Q3) correspond to zero.

20. Figure 3 shows the strong correlation that exists between fourth-quarter GDP growth and the real price of copper. ${ }^{7}$ In all three copper price cycles, GDP growth peaked one or two quarters after the copper price peaked. The expansion starting in 1990:3 and peaking in 1992:3 was the only recent Chilean business cycle that was not anticipated by the copper price cycle. However, this business cycle is atypical both for internal and external reasons.

Internally, there was the transition from the military regime to a democratic government. Externally, the expansion corresponded to the wave of capital flows to emerging markets. Schadler, Carkovic, Bennett, and Kahn (1993) explain that countries that received large capital inflows in the early 1990s experienced an economic boom, although the surge in economic activity in Chile took place with some lag. In addition, Moguillansky (1998) reports that there was considerable investment in the mining sector in the early 1990s following the previous price boom of the late 1980s. The analysis here concentrates on the three business cycles that are directly correlated with the copper price cycles.

21. Figure 4a shows the four-quarter real GDP growth in the three episodes under consideration. While in the first two cycles economic activity accelerated rapidly as the copper price increased, the last cycle is atypical because economic activity did not increase very fast during the expansionary phase. All three cycles share a sharp decline in the rate of growth of real GDP starting one or two quarters after the peak of the copper price.

22. Before analyzing the behavior of the GDP components, it is useful to clarify two issues. First, the strong relationship between GDP growth and the copper price cycle could reflect the impact of copper prices on copper output since mining, which is mostly copper, accounts for about 10 percent of Chile's GDP. To examine this issue, industrial production is used as an indicator of economic activity which does not include the copper sector directly; Figure $4 \mathrm{~b}$ shows the 4-quarter growth of industrial production during the copper cycles. Also, in this case, there is a strong correlation between the copper cycle and the cycle of economic activity. So it can be concluded that the relationship between copper cycles and GDP growth is not merely a reflection of the evolution of the mining sector. Second, it is important to clarify how a short-run shock in the copper sector is identified; the alternatives are price changes and revenue changes. This analysis uses prices because they are largely out of Chile's control in the short run. In fact, the growth of copper production does not change significantly

${ }^{7}$ For an overview of the stylized facts of the Chilean business cycle in the period 1986-97 see Belaisch and Soto (1998). 
over the copper cycle (Figure 4c), reflecting the fact that it is difficult to increase production in the short term. This allows us to focus on prices in the short-run analysis, rather than on export revenues, which is appropriate for long-run analysis when supply is responsive to price.

23. Figures 5 to 8 show the behavior of the domestic components of GDP through the three copper price cycles. All percentage changes are with respect to the same quarter of the previous year. Even though all components of GDP are procyclical, the different components show different patterns around the cycle. Private consumption tends to be smoother and to lag so that the peak in consumption is on average two quarters after the peak in the copper price. Even though private consumption is smoother than the other components of aggregate demand, its variability is quite remarkable and is difficult to reconcile with standard models of aggregate consumption behavior. The excess volatility of consumption could be explained by liquidity constraints, which are eased during periods of high copper prices. $^{8}$

24. Investment is more sensitive to the cycle, and in all cases peaks one quarter after the copper price peaks. On average, fixed investment grew by more than 30 percent on a fourquarter basis at the peak of the cycle. Given the importance of investment for the subsequent analysis, fixed investment is divided into two components: machinery and construction (Figures 7 and 8). ${ }^{9}$ Taken singularly both components show an even more remarkable similarity across cycles than aggregate investment. In particular, the investment in machinery, which is mostly imported, surged virtually at the same rate in both cases for which the data are available.

25. The foreign components of GDP and the aggregate GDP changes behave differently in relation to changes in copper prices. Imports, which are highly correlated to investment and consumption of durable goods, show a pattern similar to investment. Figure 9 shows that imports surged in tandem with every cycle and peaked one or two quarters after the peak in

${ }^{8}$ In the United States, the smoothness of consumption is mostly due to low volatility in the consumption of nondurable goods, which is roughly half as volatile as GDP, while durable goods are more volatile than real GDP (Kydland and Prescott, 1990). In the case of a developing country, most durable goods are imported and are very sensitive to the real exchange rate. As reported below, Chile's real exchange rate is linked to the copper cycle. This could explain why in periods of copper booms, consumption of imported durable goods increases, explaining the "excess volatility" of consumption over the cycle. Unfortunately, there are no disaggregated data on consumption of durable versus nondurable goods to check this hypothesis.

${ }^{9}$ Disaggregated data on investment in construction and machinery are not available on a quarterly frequency. The quarterly data were constructed assuming that the shares of investment in the two categories were the same during the year. 
the price of copper. Figure 10 shows no clear pattern for the four-quarter growth of exports. ${ }^{10}$ This is not surprising given that copper output is not responsive to copper price changes in the short run, while other exports are not influenced by the mining sector and could be damaged by the appreciation of the real exchange rate.

26. The behavior of the trade balance is ambiguous in principle because it depends on revenue from copper exports, on other exports (which are hurt by the appreciations accompanying a higher price of copper), and on imports (which surge during a copper price boom). Figure 11 shows no marked pattern of the trade balance across copper cycles. ${ }^{11}$ However, the trade balance seems to be stable during the copper boom, while worsening significantly after the copper price peak by an average of two GDP percentage points. Figure 12, which analyzes four-quarter differences in the trade balance, also shows a progressive worsening of the trade balance starting one quarter before the peak.

27. The current account as a share of GDP does not present a clear pattern over the three cyclical episodes (Figure 13). Figure 14 shows the capital account as a share of GDP; as the copper price increases, there is a surge of capital inflow which is largely due to the increase of foreign direct investment (Figure 15). This observation matches the observation that there is a surge in investment during the first phase of a copper boom; Figure 15 shows that foreign direct investment has played an important role in financing these surges. Copper booms spur an investment boom in the mining sector, especially after the mining law of 1980 (see Moguillansky, 1998) which provided the legal framework for foreign investment in the mining sector. Since the quarterly data in the analysis start in 1986, the full effect of the investment booms are observed to correspond with the copper booms.

28. The effects of copper cycles on the exchange rate are quite strong. Figure 16 shows that the changes in the nominal exchange rate are strictly correlated with the copper cycle. ${ }^{12}$ In all three cases, the nominal exchange rate appreciates (or depreciates less) during the copper boom and depreciates (or appreciates less) as the price of copper declines. On average, the turning point corresponds to the peak in the price of copper and precedes but one or two quarters the peak of the business cycle. Figure 17 shows the behavior of the real exchange rate

\footnotetext{
${ }^{10}$ Both imports and exports are measured in constant Chilean peso terms.
}

${ }^{11}$ Figure 11 shows a moving average of the trade balance in order to control for the strong seasonal variations that characterize imports and exports. For this reason, Figure 12 also shows the four quarter differences instead of the quarter-to-quarter differences. Finally, these pictures are in terms of local currency; by using dollars, a slightly different picture emerges.

${ }^{12}$ The nominal exchange rate is expressed as pesos per U.S. dollar so that a depreciation of the peso increases the nominal exchange rate. 
during the copper cycles. ${ }^{13}$ In all cases, there is a strong appreciation. On average, the real exchange rate appreciated by 8 percent with respect to the peak of the business cycle of the previous year.

29. The behavior of the nominal and real exchange rates during the cycles shows that the early phase of the copper cycle is characterized by an increase in foreign currency inflows due both to the direct effect of copper revenues and the indirect effect of the increase in foreign investment. Both factors put upward pressure on the exchange rate which in all cases appreciate until the peak of the copper price cycle. When the copper price declines, the upward pressure fades out and the appreciation of the real exchange rate slows until it stabilizes about one year after the peak of the cycle.

30. The behavior of the exchange rate has some effect on the inflation rate. Figure 18 shows the behavior of inflation during the copper cycle. During the first phase of the copper cycle, when the real exchange rate is rapidly appreciating, inflation declines in all three episodes. During the second phase, when the copper price falls and the rate of appreciation declines, inflation stops declining in two episodes and increases abruptly in the 1989:Q3 episode. In conclusion, there is an asymmetry in the relationship between inflation and copper price changes: while inflation always goes down as the price of copper increases, inflation does not go up as the price of copper decreases. This asymmetric behavior of inflation with respect to the business cycle can reflect an asymmetric response of the monetary authorities to the copper cycle as is elaborated below.

31. Figure 19 shows the real lending rate in the three episodes. ${ }^{14}$ While during the last two copper cycles there is no clear pattern, there is an interesting behavior in the first cycle. During the first phase of the cycle, in the presence of strong capital inflows, the lending rates are quite low, while in the second phase the real lending rates rise. The behavior of the interest rates may also reflect to some extent the policy response of the central bank to a weakening of the current account. During the second phase of the copper price cycle, when the copper price declines, the current account deteriorates, the peso tends to depreciate, and inflation to increase, and monetary policy tends to tighten. This interpretation of events is of course very tentative, as it is based on the three copper cycles under review and cannot be formally tested. Nevertheless, this interpretation would be consistent with official statements indicating that reducing external imbalances has been an important concern of monetary policy during the 1990 s.

\footnotetext{
${ }^{13}$ The real exchange rate is defined as an increase in the exchange rate indicates a real appreciation.
}

${ }^{14}$ Real lending rates are obtained from line $60 \mathrm{p}$ of IFS and subtracting the inflation rate. This is the rate charged by banks on loans of 30 to 89 days. For this reason, this is a good indicator of the stance of monetary policy. 
32. The behavior of share prices (Figure 20) shows some pattern as shares always peak together with the copper cycle or after one quarter later. This pattern probably reflects the behavior of the interest rate and the external sector and is only indirectly influenced by copper. The pattern of real wages is more clear (Figure 21). Real wages have had an upward trend during the period considered, but their rate of growth rises as the price of copper increases. This could reflect an increase in nominal wages, and the slowing down of inflation in the presence of backward-looking indexation. Jadresic (1997) finds evidence that "Chilean private aggregate wages during the 1980s are well described by two-year contracts that are revised every six months according to 100 percent of past inflation." Whatever the reason for the increase in the rate of growth at the beginning of the copper cycle, real wages typically slow down after the peak of copper cycles. Rising real wages could explain the increase in private consumption that is observed one or two quarters after the copper cycle peak.

33. Overall, the analysis of the last three copper cycles has shown that all three copper cycles anticipated the Chilean business cycle by one or two quarters. Moreover, all GDP components behaved similarly in the three episodes. In particular, investment, which has a high component of imports and foreign financing, seems to be particularly sensitive to the copper cycle. Copper cycles, either directly or indirectly though policy responses, have been associated with real exchange rate appreciation and disinflation.

\section{Long-Run Perspective: Copper Trends and the Chilean Economy}

34. This section analyzes the long-run effect of copper on the Chilean economy. While in the previous section the focus was on the business cycle using quarterly data, this section focuses on annual data from the beginning of the 1960s to 1997 to study the statistical relationship between developments in the copper sector and the Chilean economy. Moreover, the unit of analysis in this section is real copper export revenues, not prices, given that in the long run the copper supply is elastic. Finally, the log difference of real copper export revenues (LRCOEX) is taken in order to have a stationary explanatory variable.

35. As in the previous section, we first look at the general relationship between copper exports and the Chilean economy. Regression 1 shows how LRCOEX anticipates changes in real GDP growth. The short-term effect (annual effect) is simply the coefficient on LRCOEX, while the long- term effect takes into account the lags of the dependent variable. ${ }^{15}$ The elasticity of GDP growth to real copper revenues growth is 0.1 in the same year and 0.19 in the long run, meaning that an increase in real copper revenue growth of 10 percent increases GDP growth by 1 percent in the short run and by 1.9 in the long run. The short-term response could be due to the fact that the mining sector accounts for about 10 percent of

\footnotetext{
${ }^{15}$ Since both series (real copper exports and Chile's real GDP) have a unit root and are not cointegrated, first differences in the regression are used; the lags are chosen according to standard criteria. Log is used so that the estimated results are easily interpreted as elasticities. For other information on the regression see the technical appendix.
} 
GDP, so that a 1 percent increase in mining output means that GDP grows by 0.1 percent. However, in the long run the elasticity doubles, showing that the copper sector has a strong multiplier effect, which almost doubles its short-term impact. This result is quite robust to the time period and the specification chosen.

36. The result that LRCOEX has an effect on GDP growth both in the short- and longterm periods is complementary to the finding of the previous section that copper cycles have preceded Chilean business cycles in the last decade. Not only has copper determined fluctuations around a long-term trend, but it has also influenced this trend. Generally, the factors that determine long-term growth (such as productivity and factor accumulation) are different from the factors that determine fluctuations around the trend (such as aggregate demand), so the channels through which copper influences the Chilean economy could be different in the long and short runs. The rest of this section examines the channels through which copper influences the Chilean economy in the long run and contrasts them with the analogous channels in the short run.

37. LRCOEX does not have an influence on private consumption growth in the long run (see Regression 3 in the technical appendix). This result and our previous finding that private consumption is sensitive to the copper cycle in the short run show that copper has only a short-term effect on consumption.

38. LRCOEX has an influence on investment growth in the long run (see Regression 4 in the technical appendix). While a 10 percent increase of the rate of growth of copper exports has only a moderate immediate effect on investment, it increases real investment growth by 93 percent in the long run. This matches the finding of the previous section, in particular, the high volatility of investment growth and its strong correlation with the copper cycle.

39. Another way of looking at the effect of copper on the components of GDP is to look at income shares. Regression 5 shows that a 10 percent increase of real copper export growth does not have any effect on the investment share in the short run, but it increases the investment share by 6.6 percentage points in the long run. Since investment has an upward trend, part of this increase could be spuriously attributed to copper. However, Regression 6 , which controls for a time trend, confirms the results although the size of the effect is smaller than before: a 10 percent increase in real copper export growth increases the investment share only by 1.7 percentage points in the long run. This finding confirms the results on the business cycle of the previous section.

40. Regression 7 shows that real copper export growth has little effect on the import share in the short run, but a large effect in the long run. ${ }^{16}$ In the short run, the effect of copper

\footnotetext{
${ }^{16}$ There is a missing observation for imports; given that two lags of the dependent variable are used, the number of usable observations is reduced from 36 to 33. In principle, it is not
}

(continued...) 
on the import share is negative and not very robust. In the long run, a 10 percent increase in the growth of copper revenues increases the import share by 5.1 percentage points. If the sample is restricted to the years after 1975 to avoid clear structural breaks, this coefficient is much smaller.

41. Regression 8 provides an alternative way of looking at the effect of copper on imports by using the share of copper exports in GDP as the independent variable. In the short run, the copper export share is not correlated with import share. But, in the long run, each additional percentage point of copper exports increases imports by 0.7 percentage points. If the sample is restricted from 1975 onwards, the long-run import response decreases to 0.3 percentage points. These results merit two observations. First, they are consistent with the previous findings that an increase in copper exports translates into an investment boom which, in turn, increases imports. Second, the analysis is limited to partial equilibrium. In particular, higher investment in the mining sector means higher capacity, and so higher exports in the future. For this reason, it is not correct to say that in the long run one percentage point of higher copper revenues improves the current account only by 0.3 percentage points because this does not take into account all the secondary effects such as higher investment, or the effects on the real exchange rate.

42. In Regressions 9 to 13 , the long-run fiscal position is examined. In order to have a consistent measure over the entire period, the surplus of the central government as a share of GDP is used. An increase of real copper export growth by 10 percent improves the fiscal surplus by 0.27 percentage points in the short run, and by 1.62 percentage points in the long run. Even if the results go in the right direction and have plausible magnitudes, they are estimated imprecisely; this is because there were important structural breaks in the relation between copper and fiscal behavior in the 1970s. If the sample is restricted to the first 13 years, 1963-1975 (Regression 10), the relationship between copper export growth and the fiscal position becomes stronger (a 10 percent increase of copper revenue growth improves the fiscal position by 3.3 percentage points in the long run) and is measured more precisely. Conversely, taking the last 21 observations, 1976-96 (Regression 11), a 10 percent increase of copper export growth is found to improve the budget only by 1.2 percentage points in the long run. These results should be taken only as an indication of a trend, given that they are based on a partial equilibrium analysis and on a limited number of observations. Nevertheless, the finding that the role of copper in public finances has been diminishing over time may reflect the introduction of the copper stabilization fund, and the increased importance of other sources of revenues.

43. Regression 12 considers the effect of copper export revenues, expressed as a share of GDP, on the position of the central government. An additional GDP percentage point of

\footnotetext{
${ }^{16}$ (...continued)

advisable to use time series data with a gap in the middle. Nevertheless; the results of this regression are presented for completeness of the analysis
} 
copper exports improves the central government position by 0.5 percentage points in the short run, while the improvement rises to 0.78 percentage points in the long run. As before, the reader is cautioned that this analysis is based on a partial equilibrium and does not take into account second-order effects.

44. The fiscal position is strongly linked to the business cycle, which in turn is associated with the copper price cycle. Regressions 9 to 12 considered the total effects of copper on the fiscal position, including not only additional revenues accruing to the central government as a result of higher copper exports but also the higher tax revenues coming from stronger economic activity. In Regression 13, controls for the second effect by introducing GDP growth. When controlling for the business cycle, the effects of copper export growth are similar and still significant. In the long run, a 10 percent increase of copper export growth improves the fiscal position by 1.6 percentage points.

45. Overall, the analysis of the annual data between 1963 and 1997 suggests that copper exports have a significant effect on long run growth, especially through investment. The increase in investment in turn explains higher imports. Private consumption growth seems not to be affected by copper, while the fiscal position improves significantly as copper revenues increase. The effect on the fiscal position has become less relevant in the last decade, reflecting structural changes that have diminished the dependency and sensitivity of the fiscal accounts with respect to copper.

46. As the previous analysis is based on regressions with a limited number of observations, it also precluded the use of many control variables. For this reason, the analysis was limited to a partial equilibrium analysis and the results must be considered with care.

\section{E. Transmission Channels}

47. In the previous sections, it was established that the copper cycles have strong implications for the Chilean economy both in the short and the long runs. This section takes an alternative approach by looking separately at different possible transmission mechanisms and checking whether they are compatible with the stylized facts outlined in the previous sections.

\section{Private consumption-wealth effect}

48. A higher price of copper increases the national wealth of Chile. This could happen either directly if Chilean nationals own copper mines, or indirectly through a Ricardian equivalence if the government owns the copper mines and nationals anticipate fewer taxes in the future. In both cases, the private sector should increase consumption in response to a higher copper price. This effect should be particularly noticeable in the long run because the 
private sector would lag by several periods before updating its long-term consumption path. ${ }^{17}$ Regression 3 shows that there is no evidence of changes in consumption growth due to changes in copper export growth so a simple wealth effect mechanism can be ruled out. There are several possible reasons why the wealth effect does not play a major role: a failure of the Ricardian equivalence, credit constraints, perception that the innovations in the price of copper are not permanent, and the fact that large part of the mines in Chile are now foreignowned.

\section{Private consumption-higher wages}

49. Many studies have shown that the wages of an industry are influenced by the profitability of that industry, and is probably the case for the mining industry in Chile, so a higher copper price should push higher wages for the mining workers. Eventually, the wage increase should spread to workers in other sectors. However, this hypothesis is not very appealing because workers in the mining sector are not numerous, and are concentrated in a few regions. For these reasons, the labor market is fragmented and it is difficult to imagine the mining sector as a wage setter for the other sectors. Nevertheless, real wages have increased more as the price of copper has risen. This could be due to the fact that inflation is negatively correlated with the price of copper, which, in the presence of backward-looking indexation, leads to an increase in real wages. Additionally, the public sector, which has more resources during copper booms, could give higher nominal wage increases.

\section{Investment component-mining sector}

50. If the innovations in the price of copper are (or are perceived) as permanent, higher prices will bring new investment to the mining sector. There is strong evidence of this channel. Both short-term (Figures 7 and 8) and long-term evidence (Regression 4) show that investment is quite sensitive to the price of copper. Since the late $1980 \mathrm{~s}$ and early $1990 \mathrm{~s}$ (Moguillansky, 1998), foreign direct investment has been concentrated in the mining sector so that there has been a strong link between the copper cycle and foreign direct investment. Moreover, the cycle starting in 1990:3 and peaking in 1992:3, which was the only recent Chilean business cycle not anticipated by the copper cycle, was characterized by a surge in foreign investment mainly in the copper sector. The drawback of the high responsiveness of investment to the business cycle has been the increase in imports that accompanies every copper cycle.

${ }^{17}$ Given that the innovations in the price of copper are quite persistent, the textbook response of consumption to an innovation in the price of copper in the absence of credit constraints is an almost immediate update to the new long term path. Considering the high volatility and uncertainty, an immediate response should not be expected. 


\section{Capital inflows-perceived stability}

51. During the 1990s, Chile has followed prudent economic policies which have created a favorable framework for long-term economic growth. It is difficult to evaluate how the high copper prices have contributed to this favorable scenario. The high price of a commodity is not an automatic blessing. In fact, there are many countries for which a natural resource is a mixed blessing that leads more to rent-seeking behavior than to sound investment and development. Keeping this is mind, it is fair to say that copper export revenues, which have been wisely administered, have favored Chile's economic stability in the long run.

\section{Investment—through monetary authority response}

52. Since the beginning of the 1990s the central bank of Chile has been concerned not only with internal inflation but also with external stability, trying to limit the size of the current account deficits. During the first phase of a copper cycle, the tendency is for the current account position to improve, the exchange rate to appreciate, and inflation to diminish, thus monetary policy can be more expansive. During the second phase, however, when the price of copper declines, the current account tends to worsen, the exchange rate tends to depreciate, and inflation does not go down, monetary policy is more restrictive. The pattern of the real lending rate during the copper cycles is compatible with this hypothesis.

\section{Fiscal component}

53. CODELCO gives all of its profits under various forms to the treasury. The higher copper price can thus increase public revenues and make the budget constraint less stringent. The analysis here shows that this has happened even though this channel has probably worked more effectively in the past. In the last ten years, new institutional innovations such as the copper fund and the increased importance of alternative forms of financing, have progressively limited the importance of copper in public financing.

\section{F. Conclusions}

54. This paper has examined how the Chilean economy has responded to the copper cycle both in the long run and the short run. Tailoring the analysis to the availability of data (annual data between 1960 and 1997 and quarterly data between 1986 and 1998), statistical analysis was used for the long run, and graphic and case-by-case analysis for the short run. The two kinds of analysis are complementary since short-term and long-term adjustments are potentially different.

55. The main conclusion of the analysis is that copper prices are important for short-term fluctuations and probably have an influence on long term growth. While many mechanisms can be at work, investment seems to play a major role. During periods of high copper prices, both internal and external factors favor investment. Internally, lower current account deficits probably lead to less stringent monetary policy. Externally, international investors are 
attracted by the high copper price and by the enhanced long-term external stability. Additionally, the high copper price and capital inflows have typically created upward pressure on the real exchange rate in the first phase of the copper cycles. The rapid appreciation and increased demand for investment goods have, however, partially offset the positive effects of copper on the current account.

56. The appreciation of the Chilean peso during the first part of the copper cycle has also favored the policy of progressive disinflation pursued by the central bank of Chile. Typically, the fastest gains in the disinflation policy have been obtained when the copper price was increasing, while the central bank has consolidated the gains in disinflation during periods of a decreasing copper price. In the presence of backward-looking indexation, this also may explain how real wages have grown more rapidly during the phase of increasing copper prices.

57. Unlike other countries endowed with natural resources, there is only limited evidence of consumption booms induced by the copper cycle in the short run. In the short run, part of the increase in consumption could be indirectly due to the higher real wages and decreasing inflation at the beginning of the copper cycle. Moreover, there is little evidence of share booms during the cycles probably because foreign capital has not been invested through the stock market. Copper cycles have also been very relevant for the fiscal balance, even though their importance has been decreasing thanks to the development of alternative sources of revenue and the introduction of the copper stabilization fund.

58. This paper has described the stylized facts about the correlation between the Chilean economy and the copper cycle. Copper has played an important role in the Chilean economy but the reasons for Chile's success in the last decade are much more complex and go beyond the development in the copper sector. The endowment of a natural resource is no substitute for competent micro and macro economic management. 


\section{References}

Bande, Jorge, and Ricardo Ffrench-Davis (1989), Copper Policies and the Chilean Economy: 1973-88. Notas técnicas Number 132. Cieplan. September, Santiago, Chile.

Belaisch, Agnès, and Claudio Soto (1998), Empirical Regularities of the Chilean Business Cycle. Mimeo. Santiago, Chile.

Borensztein, Eduardo, Mohsin S. Khan, Carmen M. Reinhart, and Peter Wickham (1994), The Behavior of Non-Oil Commodity Prices, IMF Occasional Paper No. 112, August, IMF: Washington.

Calvo, Guillermo, and Enrique Mendoza (1998), Empirical Puzzles of Chilean Stabilization Policy. Paper prepared for the Seminar 'Chile Development lessons and Challenges' organized by the World Bank, March.

CODELCO (Corporacion Nacional del Cobre de Chile) (1998), Statistical Bulletin, Santiago, Chile.

Eduardo, Engel, and Patricio Meller (1992), editors Shocks Externos y Mecanismos de Estabilización. Cieplan and IDB. Alfabetas Impresores: Santiago, Chile.

Jadresic, Esteban (1997), What Type of Contracts Underlie Aggregate Wage Dynamics?. IMF Working Paper 97/67, May.

Kydland, F, and E. Prescott (1990), Business Cycles: Real Facts and a Monetary Myth, Quarterly Review. Federal Reserve of Minneapolis, Spring.

Moguillansky, Graciela (1998), Chile: las Inversiones en el Sector Minero 1980-2000. United Nations Commission for Latin America.

Morandé, Felipe, and Rodrigo Vergara (1997), editors Análisis Empirico del Crecimiento en Chile. Centro de Estudios Públicos and Ilades. Andros Impresores: Santiago, Chile. and Jorge Quiroz (1996), The Copper Boom in the Chilean Economy: What Should we Expect? . Mimeo. Comisión Chilena del Cobre. Dirección de Estudios. DE/16/96: Santiago, Chile, August.

Pascó-Font, Alberto (1995), editor La Administración de los Ingresos por Exportaciones Mineras en Bolivia, Chile y Perú. GRADE. Lima, Peru. 
Romaguera, Pilar, and Dante Contreras (1995), "Impacto Macroeconómico de la Instabilidad del Precio del Cobre en la Economía Chilena," in Pascó-Font, Alberto editor La administración de los ingresos por exportaciones mineras en Bolivia, Chile y Perú. GRADE. Lima, Peru.

Schadler, Susan, Maria Carkovic, Adam Bennett, and Robert Kahn (1993). Recent Experiences with Surges in Capital Inflows, IMF Occasional Paper No.108, December, IMF: Washington.

World Metal Statistics, Various Issues, Published by World Bureau of Metal Statistics. 
Table 1. World Copper Reserves

(In millions of metric tons)

\begin{tabular}{lrrrr}
\hline Country & Basic Reserves 1/ & $\begin{array}{c}\text { Percent of } \\
\text { total reserves }\end{array}$ & Reserves 2/ & $\begin{array}{c}\text { Percent of } \\
\text { total reserves }\end{array}$ \\
\hline Chile & 163.0 & 25.9 & 88.0 & 27.5 \\
United States & 90.0 & 14.3 & 45.0 & 17.0 \\
China & 37.0 & 5.9 & 18.0 & 5.6 \\
Poland & 36.0 & 5.7 & 20.0 & 6.3 \\
Zambia & 34.0 & 5.4 & 12.0 & 3.8 \\
Russia & 30.0 & 4.8 & 20.0 & 6.3 \\
Congo (Kinshasa) & 30.0 & 4.8 & 10.0 & 3.1 \\
Mexico & 27.0 & 4.3 & 15.0 & 4.7 \\
Peru & 24.0 & 3.8 & 7.0 & 2.2 \\
Canada & 23.0 & 3.7 & 10.0 & 3.1 \\
Australia & 23.0 & 3.7 & 7.0 & 5.1 \\
Other Countries & 113.0 & 17.9 & 68.0 & 21.3 \\
Total & 630.0 & 100.0 & 320.0 & 100.0 \\
\hline
\end{tabular}

Source: U.S. Geological Survey, Mineral Commodities Summaries (January 1998).

1/ Basic reserves include all known reserves.

2/ Reserves include only reserves which are economically viable. 
Table 2. World Copper Production by Countries or Regions (Percentage of world production)

\begin{tabular}{lrrrrrrr}
\hline & 1992 & 1993 & 1994 & 1995 & 1996 & 1997 & 1998 \\
\hline Chile & 23 & 24 & 25 & 27 & 31 & 32 & 34 \\
U.S.A. & 21 & 21 & 21 & 20 & 19 & 19 & 17 \\
Canada & 9 & 9 & 7 & 8 & 7 & 6 & 7 \\
Zambia & 5 & 5 & 4 & 4 & 3 & 3 & 4 \\
Peru & 4 & 4 & 4 & 4 & 5 & 5 & 4 \\
Europe & 4 & 4 & 4 & 4 & 3 & 3 & 3 \\
China & 4 & 4 & 5 & 5 & 4 & 4 & 3 \\
Asia excluding China & 8 & 8 & 8 & 9 & 8 & 8 & 9 \\
Others & 21 & 21 & 22 & 21 & 20 & 19 & 18 \\
\hline
\end{tabular}

Source: World Metal Statistics (various issues). 
Table 3. Copper Consumption by Countries or Regions

(Percentage of the world consumption)

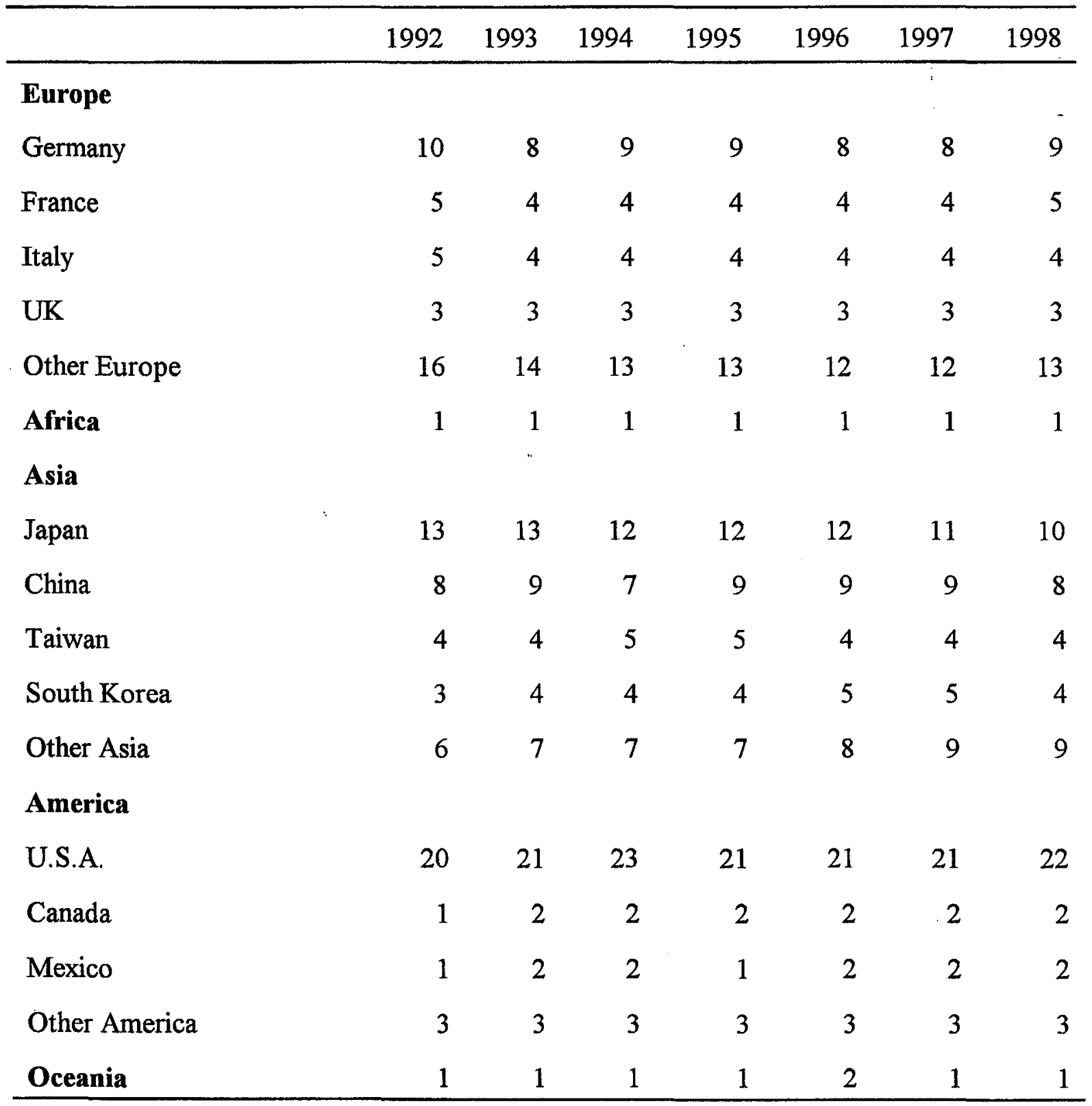

Source: World Metal Statistics (various issues). 

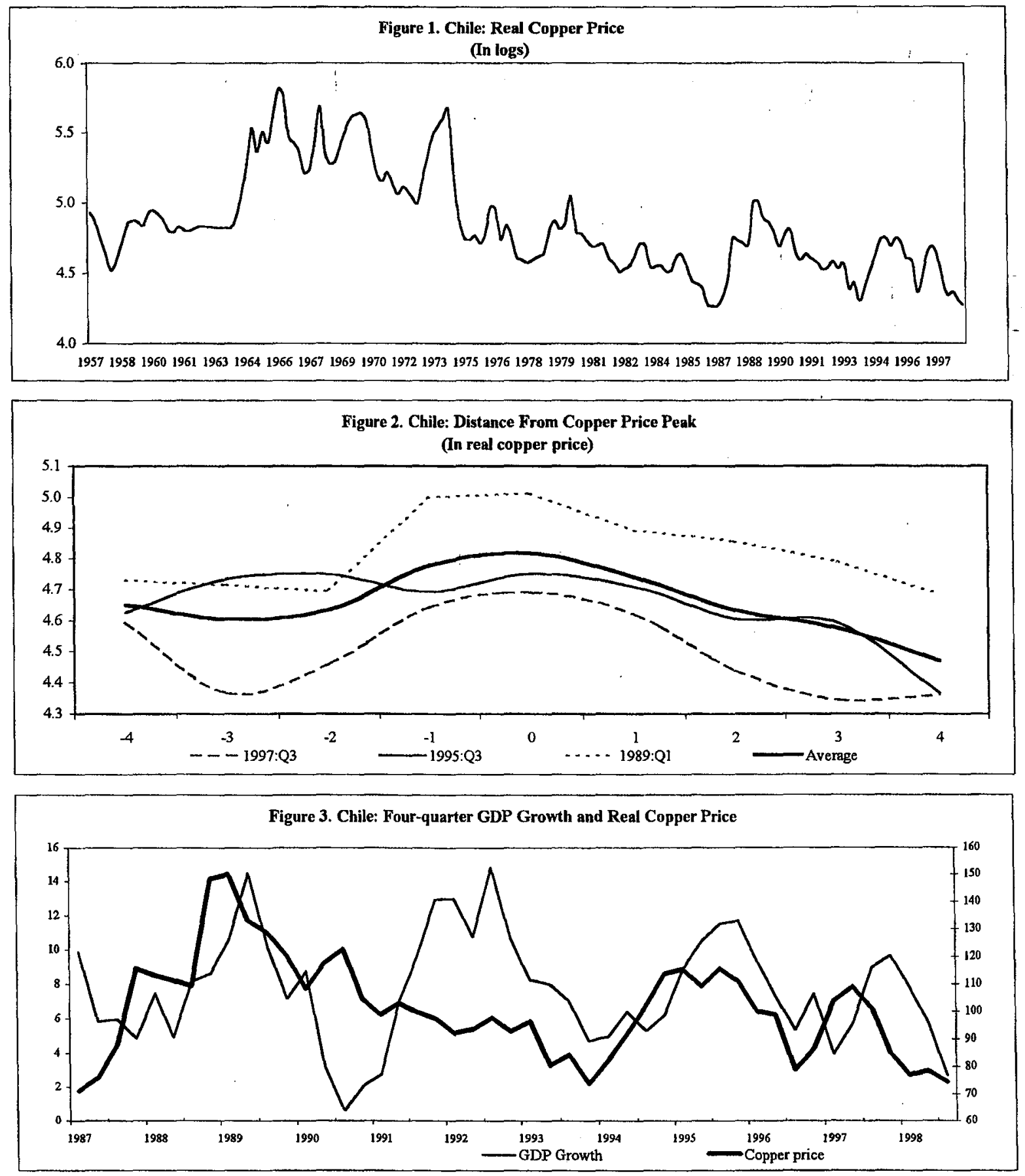

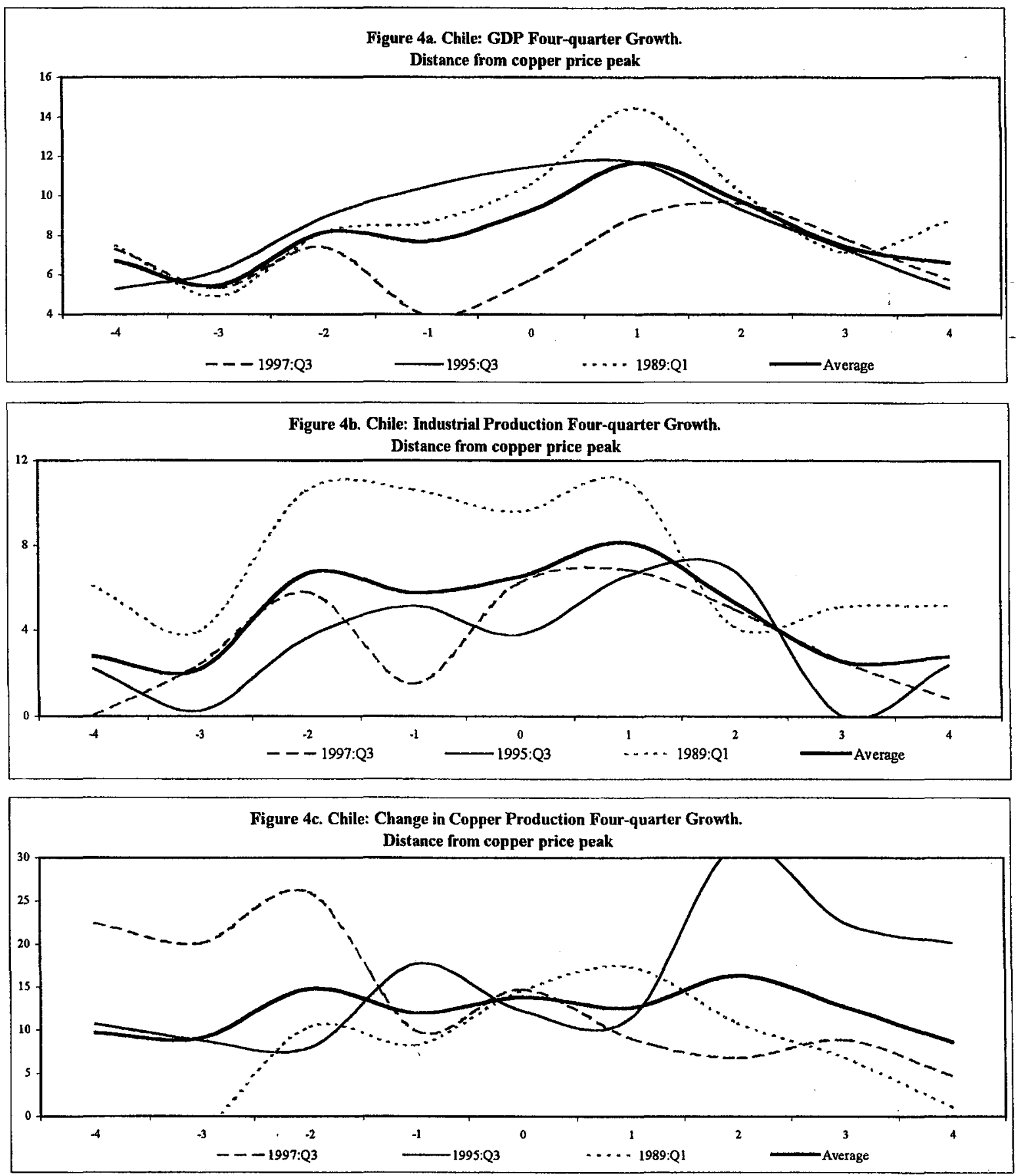

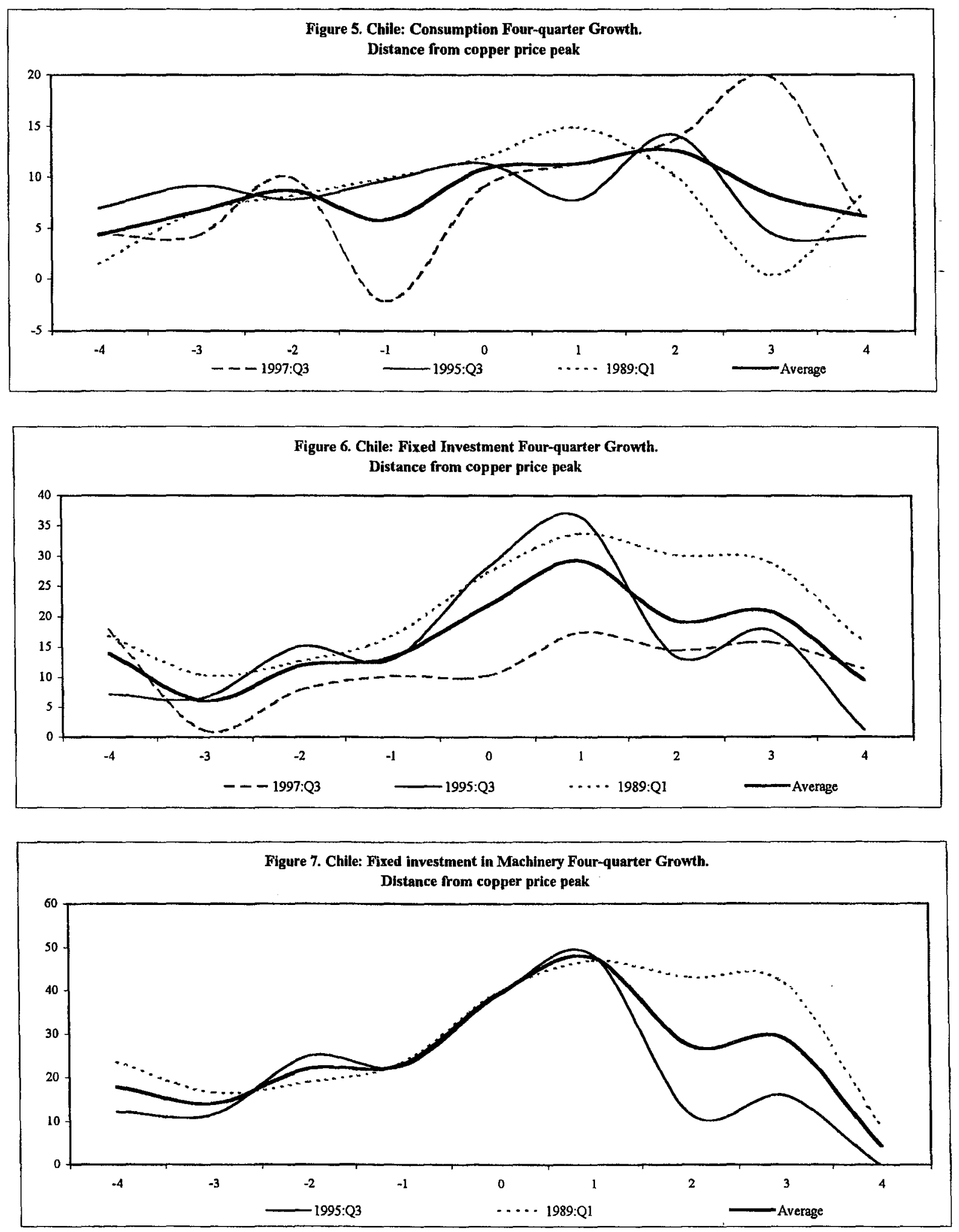

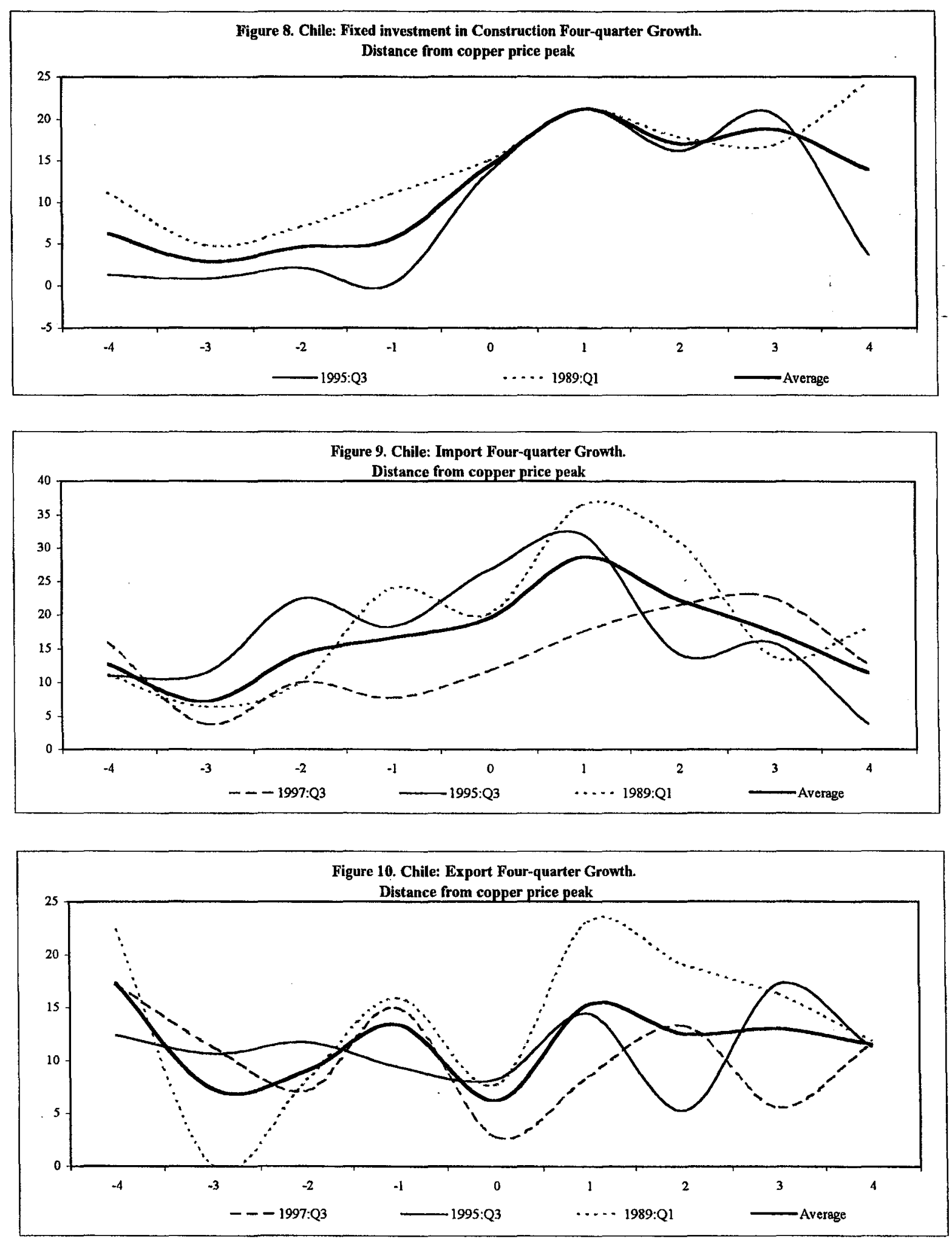

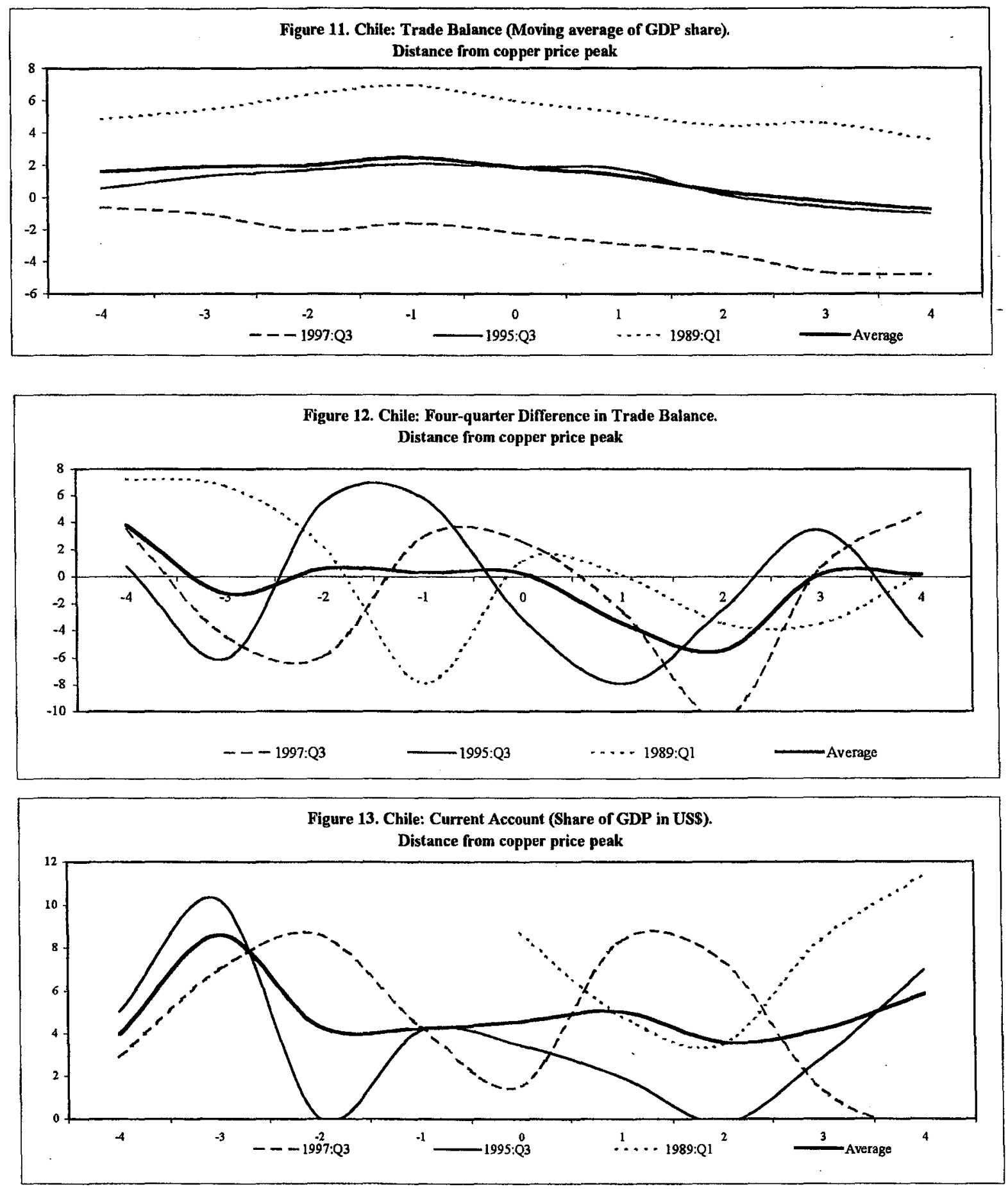

CInternational Monetary Fund. Not for Redistribution 

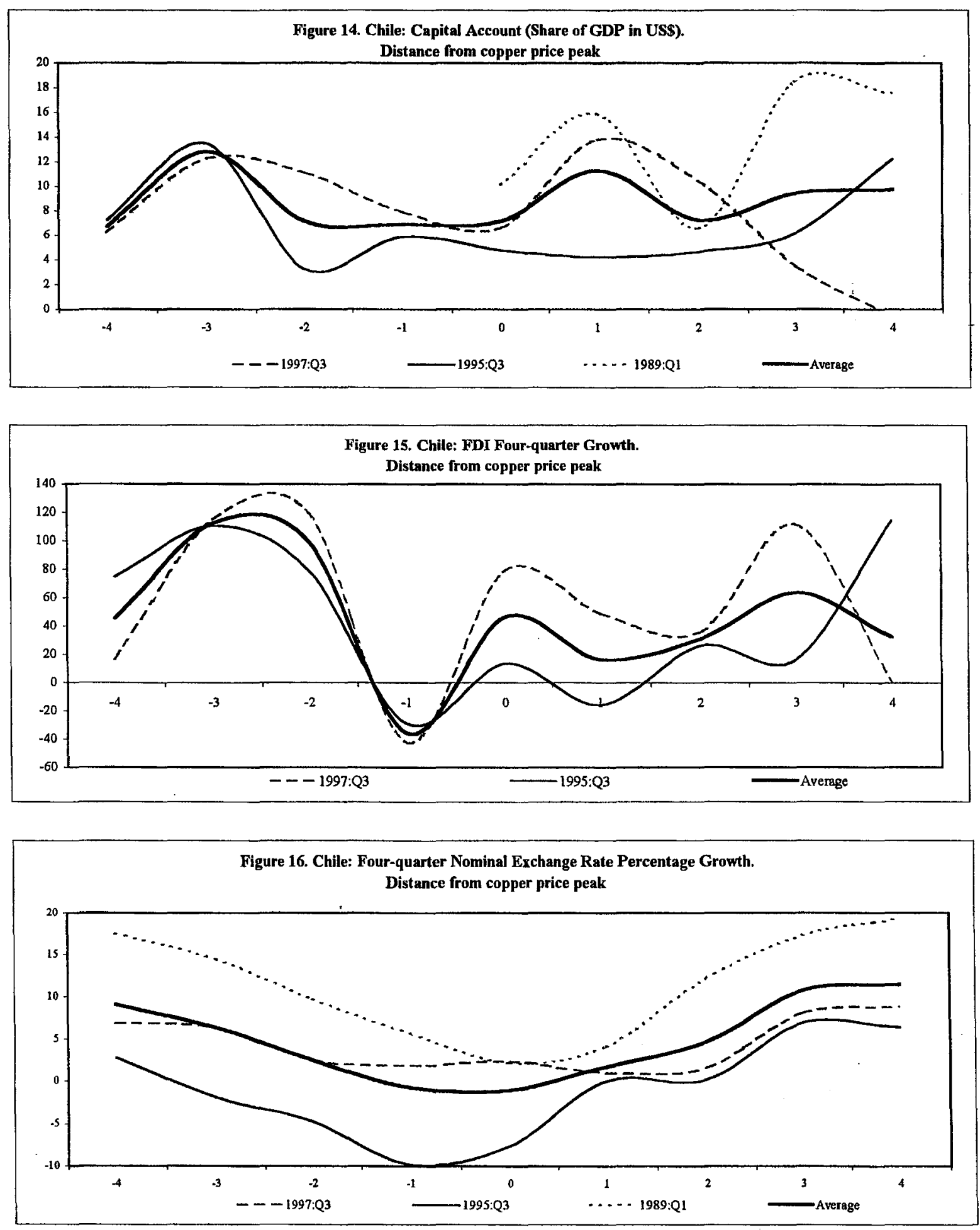

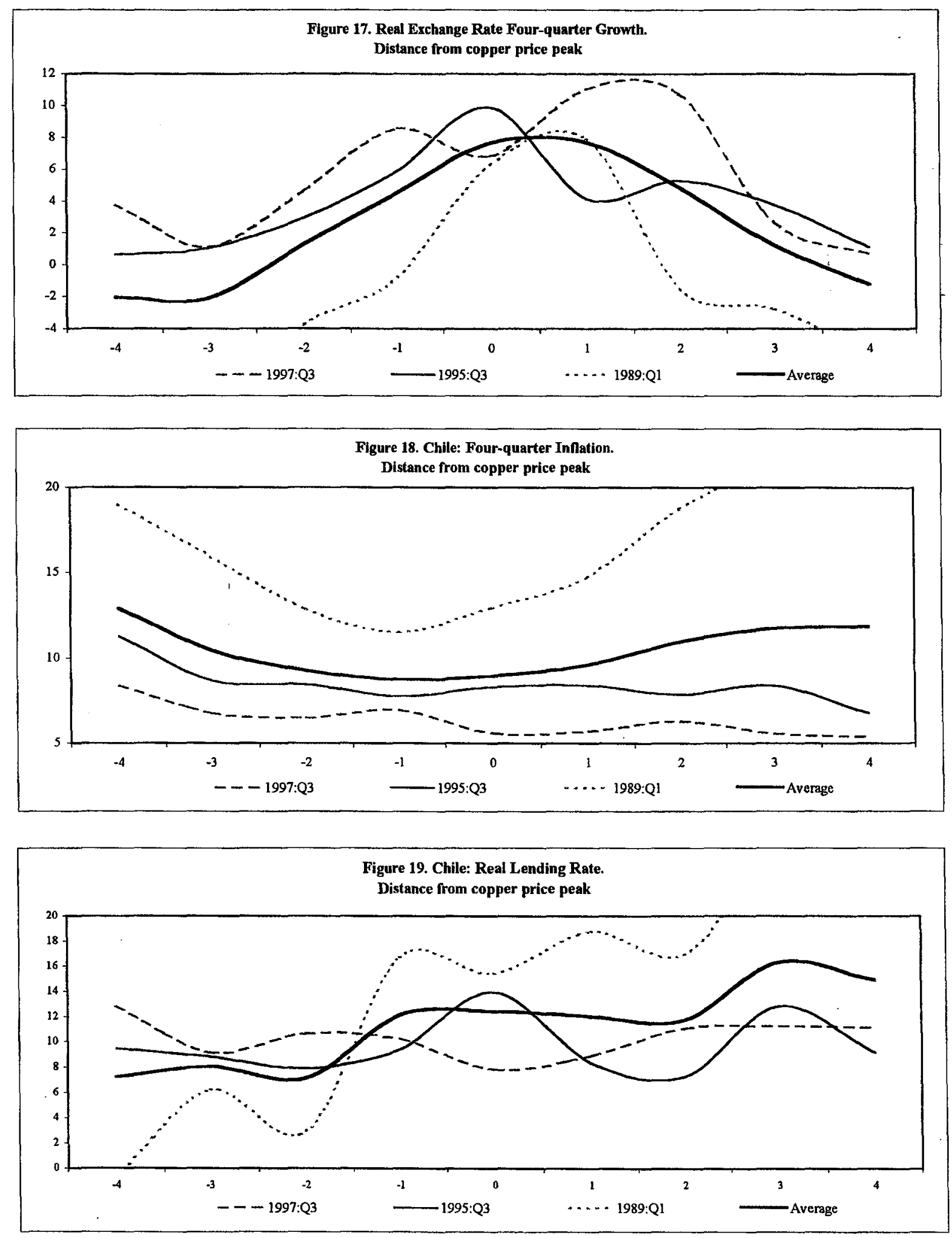

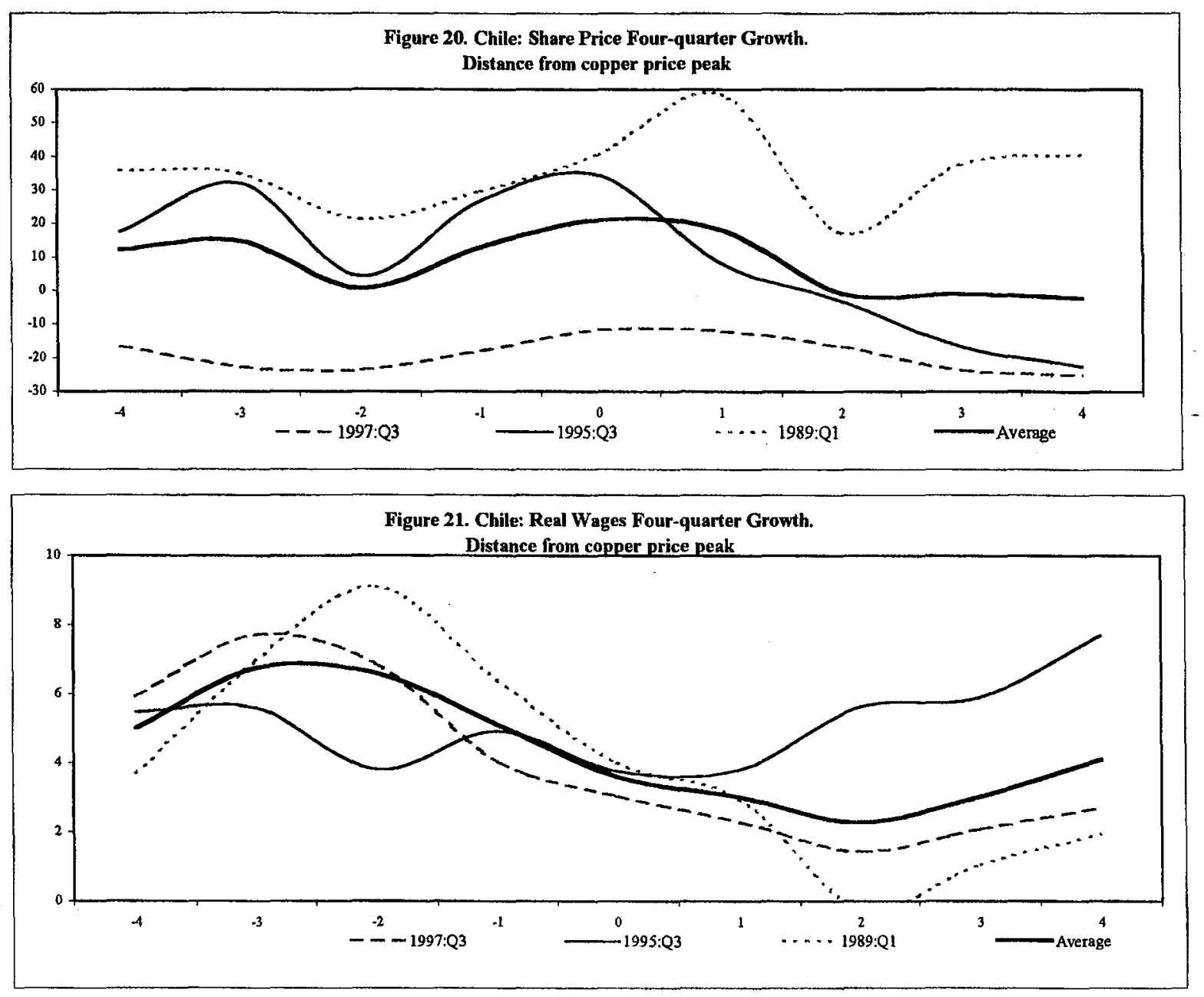


\section{Regressions $^{1}$}

\begin{tabular}{|c|c|c|c|c|c|c|c|c|}
\hline Regression & $\mathbf{I}$ & II & III & IV & $\mathbf{v}$ & VI & VII & VIII \\
\hline Dependent variable & gdp growth & $\log \operatorname{gdp}$ & $\begin{array}{l}\text { consumption } \\
\text { growth }\end{array}$ & $\begin{array}{l}\text { investment } \\
\text { growth }\end{array}$ & $\begin{array}{l}\text { investment } \\
\text { share }\end{array}$ & $\begin{array}{l}\text { investment } \\
\text { share }\end{array}$ & $\begin{array}{l}\text { import } \\
\text { share }\end{array}$ & $\begin{array}{l}\text { import } \\
\text { share }\end{array}$ \\
\hline period & $62-97$ & $62-97$ & $63-97$ & $62-97$ & $62-97$ & $62-97$ & $62-97$ & $62-97$ \\
\hline lag gdp growth & $.31(2.28)$ & & & & & & & \\
\hline copper export growth & $.10(1.71)$ & & $-.04(-.65)$ & & $.00(.35)$ & $.00(.39)$ & $\begin{array}{l}-.03- \\
1.55)\end{array}$ & \\
\hline lag copper exp. growth & $.03(.76)$ & & & & $.04(3.19)$ & $.04(3.32)$ & $.07(3.84)$ & \\
\hline $\operatorname{lag} \log g d p$ & & $1.22(12.65)$ & & & & & & \\
\hline second lag log gdp & & $-.45(-3.36)$ & & & & & & \\
\hline log copper export & & $.11(1.92)$ & & & & & & \\
\hline trend & & $.01(2.62)$ & & $0.00(1.33)$ & & $.00(2.51)$ & & $.00(2.81)$ \\
\hline $\begin{array}{l}\text { lag consumption } \\
\text { growth }\end{array}$ & & & $.52(2.50)$ & & & & & \\
\hline $\begin{array}{l}\text { second lag cons. } \\
\text { growth }\end{array}$ & & & $-.22(-1.43)$ & & & & & \\
\hline lag investment growth & & & & $-.07(-.35)$ & & & & \\
\hline copper price growth & & & & $.44(1.84)$ & & & & \\
\hline lag investment share & & & & & $.93(11.96)$ & $.73(6.84)$ & & \\
\hline lag import share & & & & & & & $\begin{array}{l}1.01 \\
(7.43) \\
\end{array}$ & $.40(2.09)$ \\
\hline $\begin{array}{l}\text { second lag import } \\
\text { share }\end{array}$ & & & & & & & $\begin{array}{l}-.10(- \\
0.71)\end{array}$ & $.04(.23)$ \\
\hline copper export share & & & & & & & & $.22(.81)$ \\
\hline lag copper export share & & & & & & & & $.17(.64)$ \\
\hline \multicolumn{9}{|l|}{ Long term effects } \\
\hline copper export growth & $\begin{array}{l}.19 \\
(.08) \\
\end{array}$ & & $\begin{array}{r}-0.05 \\
(.52)\end{array}$ & & \begin{tabular}{|l}
.66 \\
$(0.03)$ \\
\end{tabular} & $\begin{array}{l}.17 \\
(.02) \\
\end{array}$ & $\begin{array}{l}.51 \\
(.13) \\
\end{array}$ & \\
\hline copper export & & $\begin{array}{l}.46 \\
(.06)\end{array}$ & & & & & & \\
\hline copper price growth & & & & $\begin{array}{l}.41 \\
(.08)\end{array}$ & & & & \\
\hline copper export share & & & & & & & & $\begin{array}{l}.70 \\
(.10) \\
\end{array}$ \\
\hline
\end{tabular}

${ }^{1}$ The explanations of the variables is at the end of the appendix. 
APPENDIX

\begin{tabular}{|c|c|c|c|c|c|}
\hline Regressions & $\mathbf{I X}$ & $\mathbf{x}$ & $\mathbf{X I}$ & XII & XIII \\
\hline Dependent Variable & gvt surplus & gvt surplus & gvt surplus & gvt surplus & gvt surplus \\
\hline period & $63-96$ & $63-75$ & $76-96$ & $62-96$ & $63-96$ \\
\hline lag gvt surplus & $1.04(6.14)$ & $-.12(-.20)$ & $.87(4.42)$ & $1.02(4.40)$ & $1.04(4.91)$ \\
\hline second lag gvt surplus & $-.39(-2.31)$ & $.17(0.30)$ & $-.39(-2.17)$ & $-.29(-1.63)$ & $-.39(-2.02)$ \\
\hline copper export growth & $.03(1.51)$ & $.06(1.73)$ & $.03(1.56)$ & & $.03(1.04)$ \\
\hline lag copper export growth & $.01(.50)$ & $.13(1.48)$ & $.01(.77)$ & & $.01(.54)$ \\
\hline $\begin{array}{l}\text { second lag copper export } \\
\text { growth }\end{array}$ & $.02(1.04)$ & $.13(2.08)$ & $.02(1.13)$ & & $.02(1.30)$ \\
\hline copper export share & & & & $.50(2.09)$ & \\
\hline lag copper export share & & & & $-.28(-1.19)$ & \\
\hline gdp growth & & & & & $.01(.07)$ \\
\hline \multicolumn{6}{|l|}{ Long term effects } \\
\hline copper export share & & & & $\begin{array}{l}.78 \\
(.10)\end{array}$ & \\
\hline copper export growth & $\begin{array}{l}.16 \\
(.18)\end{array}$ & $\begin{array}{l}.33 \\
(.05)\end{array}$ & $\begin{array}{l}.12 \\
(.13)\end{array}$ & & $\begin{array}{l}.16 \\
(.15)\end{array}$ \\
\hline
\end{tabular}

Note: $t$-statistics are in parenteheses beside the coefficients; while p-values are below the coefficient for the long term effects.

gdp growth

gdp

consumption growth

Investment growth

Investment share

Import share

gvt surplus

copper export growth copper price growth copper export share log difference of real GDP at 1986 constant prices.

$\log$ real GDP at 1986 constant prices.

$\log$ difference of private consumption in constant 1986 prices.

log difference of investment in constant 1986 prices

real investment as a share of real GDP

real imports as a share of real GDP

surplus of the central government as share of GDP

$\log$ difference of real copper export revenues

log difference of real copper price

copper export revenues as a share of GDP 


\section{NONRenewable Resources: A Case for Persistent Fiscal SuRPluses ${ }^{18}$}

\section{OVERVIEW}

This chapter addresses a general question: is there a case for temporary but persistent fiscal surpluses in economies, like Chile, heavily endowed with nonrenewable resources? Our answer is that this is generally the case. Unless government preferences are strongly biased towards present and near-future generations, it will have incentives to save at leastpart of the revenues it derives from the exploitation of an exhaustible resource by running fiscal surpluses. These surpluses will permit the replacement of nonfinancial wealth with financial assets, the return on which can be used to increase public consumption possibilities of future generations for a constant across-generation tax burden. The size of the initial surpluses is determined by the government's relative time-preference: the more biased government's preferences are toward present and near-future generations, the lower the initial surpluses will be, and the lesser the provision of public goods to future generations for a steady tax burden over time. Moreover, the larger the size of the finite endowment the larger the initial surpluses. Chile's large copper reserves, the largest for any country, call for a special consideration of fiscal policies. It must be emphasized at the outset that the discussion in this chapter is based on a stylized model, subject as usual to many caveats, and intends only to highlight the intergenerational considerations that would be important to take into account when analyzing fiscal policy from a long-term perspective. In a more general framework, which includes the possibility of public investment, the results obtained in this chapter could be rephrased as the proposition that the existence of nonrenewable resources would imply, ceteris paribus, stronger initial fiscal positions rather than initial fiscal surpluses.

\section{A. Introduction}

59. The purpose of this chapter is to examine, in a stylized theoretical framework, whether the presence of sizable exhaustible resources in an economy affects the path of optimal primary fiscal balances. More specifically, could the existence of nonrenewable resources create a case for transitory but persistent fiscal surpluses? We found that for economies heavily endowed with nonrenewable resources, like Chile, that is generally the case. During the time when fiscal revenues are derived from an exhaustible resource the government would run fiscal surpluses which would permit the replacement of nonfinancial wealth with financial assets. The return on those financial assets would be used in future periods to finance

\footnotetext{
${ }^{18}$ Prepared by Max Alier and Martin Kaufman. We are grateful to Pablo Cabezas, Nicolás Eyzaguirre, Guillermo Larrain, Saul Lizondo, Francisco Nadal-De Simone, Piritta Sorsa, and Antonio Spilimbergo for comments and suggestions. We thank also participants in a seminar held at the Central Bank of Chile.
} 
government expenditures. Government preferences regarding the welfare of different generations and the size of the finite resource determine the size of the initial surpluses and, for a steady tax burden over time, also the path for government expenditures.

60. The issue of nonrenewable resources and its optimal depletion has been discussed at length since Hotelling's (1931) seminal paper. The topic of fiscal policy in presence of nonrenewable resources has received recently some attention since it is of great relevance to a group of countries, like Chile, in which the exploitation of exhaustible endowments have a significant impact on their economies and fiscal stances. This literature has focused on general conditions for policy sustainability, on financial and wealth indicators to track the evolution of government solvency, and on intergenerational transfer issues in presence of depletable resources. ${ }^{19}$

61. The relevance of the issue discussed in this chapter is intrinsically linked to the economic size of the nonrenewable resource. In the case of Chile, total copper reserves amount to 163 millions of metric tons or 26 percent of total world reserves, ${ }^{20}$ the largest reserve base for any country. The economically usable reserves total 88 millions of metric tons or 28 percent of world reserves. At the current rate of production, Chile has 26 years of economically usable reserves, and almost 50 years of total reserves (which can become usable as technology evolves).

62. Assuming a decade-average copper price of US\$1 per pound and using Chile's 1998 GDP and copper-price discount, ${ }^{21}$ the value of total reserves is equivalent to 2.5 times the annual GDP, while economically usable reserves stand to about 1.8 times GDP. Moreover, using an estimated total mining cost of US $\$ 0.7$ per pound, the net worth of total reserves would amount to 70 percent of 1998 GDP, and economically usable reserves would represent 50 percent of $1998 \mathrm{GDP}$. In the fiscal accounts, fiscal revenues only from the state copper company CODELCO have averaged 2.2 percent of GDP in the 1990s. It can then be presumed that fiscal policy in Chile should be subject to the particular considerations that this paper intends to highlight.

\footnotetext{
${ }^{19}$ See for example Chalk (1998) on the issue of sustainability and Liuksila et al. (1994) on wealth indicators for the public sector both in presence of depletable resources. Steigum and Thøgerson (1995) use a computable overlapping generation model to study the effect of oil depletion in Norway, and Auerbach et al. (1993) apply a generational accounting framework with nonrenewable resources to study the extent of intergenerational transfer in Norway.

${ }^{20}$ According to the January 1998 Mineral Commodities Summaries of the U.S. Geological Service. It must be emphasized that estimated reserves tend to be a dynamic concept affected, for example, by technological improvements.

21 The copper price discount considered for Chile's exports is 4 US dollar cents per pound. In addition, the real interest rate used to discount the flow of income is 5 percent.
} 
63. The chapter is organized as follows: Section B presents a simple framework to analyze fiscal policy in the presence of nonrenewable resources. Section $\mathrm{C}$ restates the main findings and policy implications. Appendices I and II develop in detail the model presented in Section B.

\section{B. A Stylized Model of Fiscal Policy with Nonrenewable Resources}

64. This section outlines a simple extension of the nonstochastic overlapping generation (OLG) model which we developed to better understand the economic implications of nonrenewable resources on fiscal policy. ${ }^{22} \mathrm{~A}$ basic two-generation OLG model is set in the context of a small open economy with free trade in goods and financial assets with the rest of the world. In addition to consumers there is a government which provides a public good. The government finances its operations with lump-sum taxes levied on consumers and with the proceeds from the exploitation of an exhaustible resource it owns. The country is assumed to have no influence on the international price for the exhaustible resource.

65. We also assume that there is no production in the economy and consumers are endowed with a constant amount of the consumption good in every period. Consumers make their consumption/saving decisions taking into consideration their intertemporal preferences, the interest rate, the lifetime endowment, and taxes to be paid to the government. Consumers are born with no assets and leave none to their offsprings. In every period consumers derive utility from the consumption of both private and public goods. The public good is consumed in the same amount by all consumers alive in the period that the good is provided. ${ }^{23}$

66. The government decides on the level of taxation and the provision of the public good taking into account the utility of both current and future generations. We assume that the government pursues only policies that are consistent with public sector solvency. ${ }^{24}$ Therefore,

${ }^{22}$ The OLG model was initially developed by Samuelson (1958) and Diamond (1965). Appendix I presents in detail the model discussed in this section.

${ }^{23}$ As discussed later on in Section C, if government expenditure is also investment the results obtained here could be rephrased as the proposition that the existence of nonrenewable resources, ceteris paribus, would imply a stronger initial primary balance (larger surplus or lower deficit) than otherwise.

${ }^{24}$ Government solvency is defined as the set of policies satisfying ex ante the government's intertemporal budget constraint (this constraint is always met ex post through the adjustment of the primary fiscal position or the various ways of debt repudiation). On computational problems see Blejer and Cheasty (1991), and on the study of the government solvency constraint through the analysis of time-series properties of public debt see Hamilton and Flavin (1986) and Wilcox (1989). A more restricted concept is that of fiscal sustainability 
the present value of planned primary budget deficits cannot be greater than the government's initial total wealth, including its nonfinancial wealth which in this case comprises only the market value of the reserves of the exhaustible resource. In addition, to abstract from political-economy considerations we assume that the government counts with commitment mechanisms to prevent intertemporal inconsistencies in its decision making process.

67. For the sake of simplicity, we also assume that there are no domestic assets. Both the government and consumers can accumulate foreign assets or liabilities at a given international interest rate.

68. The distinctive feature of the framework presented here is that the government receives an endowment for a finite number of periods. The present value of the stream of proceeds derived from such endowments is considered the government's nonfinancial wealth. Total government wealth at any period of time comprises both nonfinancial and financial wealth, the latter consisting of net financial asset holdings.

69. For simplicity we assume that the international interest rate is constant over time, the government's endowment is constant during the periods it exists, the world price for the resource is given and constant, and the per capita lump-sum taxes are constant over time and across generations. The latter assumption allows to focus on the evolution in the per capita provision of the public good. That is, for a constant-over-time tax burden per capita, what path of the primary fiscal stance would permit, for example, a constant or increasing provision of the public good?

70. In this set up we obtained that the path of the per capita provision of the public good and the primary fiscal balance depend on the government's intergenerational preferences. Thus, if the government cares strongly for future generations it will pursue a policy of increasing per capita expenditures over time which will require larger initial primary fiscal surpluses. In contrast, if the government's preferences are biased toward present and nearfuture generations, government expenditures per capita will diminish which will determine lower initial surpluses. Of course, an intermediate case in which the government's preferences determine a constant per capita provision of the public good is also possible.

71. These three cases are depicted in Figure 1a (in per capita terms) and Figure 1b (in percent of GDP). The fine solid lines show government expenditures which are constant, increasing and decreasing in the top, middle and bottom graphs respectively. Constant taxes

\footnotetext{
${ }^{24}$ (...continued)

which is defined as the set of fiscal policies that the government can, ceteris paribus, continuously pursue without the need of future reversals. Sustainable fiscal policies need to satisfy the solvency constraint, but the converse is not true. The model developed could also be used to analyze policy sustainability. On indicators of sustainability see Horne (1991), and on debt sustainability see Zee (1988).
} 
are shown with bold dashed lines, while the income from the non renewable resource is depicted with fine dashed lines. The resulting primary fiscal deficit is presented in bold solid lines. The paths of primary deficits show in general an initial primary surplus ${ }^{25}$ i.e., the replacement of nonfinancial wealth with financial assets. The accumulation of financial assets implies higher future interest income and thus the ability to run primary deficits. Case I and ii show a clear pattern of primary surplus when the finite resource exists and primary deficits thereafter. Case iii shows an initial primary surplus followed by a deficit that eventually turns back to a surplus. ${ }^{26}$

72. Moreover, as illustrated in these figures, the less biased government preferences are toward present generations, the higher the initial surpluses. Conversely, initially weaker primary fiscal stances, ceteris paribus, show implicitly the government's relative disinterest for the future generations, highlighting the intergenerational implications of policies, i.e., lower sustainable primary deficits in the future and a lower provision of the public good. ${ }^{27}$

73. Furthermore, counter to some casual views that a larger depletable resource would merit less an initial surplus (because it would resemble more closely a permanent resource) we found, as displayed in Figure $2 a$ and $2 b$, that as long as the resource is finite the larger its size the higher the optimal initial primary surplus in all cases. Also, Figure 3 shows, for the per capita constant expenditure case, that the initial per capita surplus moves equiproportionally with the present value of the endowment, i.e., the percentage increase in the primary surplus is the same as that of the endowment. ${ }^{28}$

\section{Conclusion and Policy Implications}

74. The aim of this chapter has been to analyze fiscal policy in presence of nonrenewable resources that provide a source of temporary revenue for the government. The question posed has been: what would be the optimal path for the primary balance in those circumstances? We

${ }^{25}$ See Appendix II for initial conditions on government financial assets to have initial fiscal surpluses.

${ }^{26}$ Although Figures $1 \mathrm{a}$ and $1 \mathrm{~b}$ do not show the return to a primary surplus, in time as consumption per capita diminishes the constant tax burden will determine a turn around from deficit to surplus in the primary balance.

${ }^{27}$ The generational accounting approach highlights the zero-sum nature of fiscal policies from an intergenerational perspective, see Auerbach et al. (1994). On the shortcomings of using conventional budget accounting see Kotlikoff (1993).

${ }^{28}$ The per capita increasing expenditure case shows a less than proportional percentage increase in the initial surplus, while the expenditure decreasing case exhibits a more than proportional percentage increase. 
constraint the answer to a smaller subset by assuming that lump-sum taxes are constant over time. Thus we ask, for the same tax burden per capita across generations, what path of the primary fiscal stance would permit, for example, a constant or increasing provision of the public good? The answer we found is that in general the government needs to run primary surpluses while the finite resource exists. Depending on the government's intergenerational weights, i.e., how much it discounts future generations' welfare, the path of primary balances will turn into a permanent or transitory deficit thereafter. In terms of a more general class of questions, the existence of nonrenewable resources will constitute a case for temporary but persistent fiscal surpluses.

75. Two interesting results were also obtained. We found that the larger the resource the higher the optimal initial primary surplus. Moreover, the per capita primary surplus is shown to move equiproportionally with the size of the finite endowment for the constant expenditure case.

76. Notwithstanding the robustness of the results obtained, several caveats apply:

- In the model developed, public expenditure is purely a consumption good. In the case where public expenditure is also investment (both in human and physical capital), the analysis becomes more complicated since socially beneficial projects (in presence of, for example, high returns or positive externalities) could determine a path of initially optimal primary deficits because it may be optimal to invest heavily in the initial periods. ${ }^{29}$ Nonetheless, ceteris paribus, the existence of a nonrenewable resource would imply a stronger initial primary balance (larger surplus or lower deficit) than otherwise. ${ }^{30}$

- The model also assumes perfect foresight. However, even if the size of the resource or its future economic value were uncertain ${ }^{31}$ as long as the government is risk-neutral the general result derived above would be maintained.

- The model also ignores optimal depletion issues by assuming a given rate of exploitation of the natural resource. If the government could decide on the rate of exploitation the problem would become more complex, as new factors would enter into the analysis, but the overall

${ }^{29}$ Notice that this introduces definitional problems in the fiscal accounts since some current expenditures, for example in education and public health, could well be regarded as capital expenditures.

${ }^{30}$ Additionally, the results derived in this chapter can be preserved by expressing them in terms of fiscal savings rather than primary balances.

${ }^{31}$ In this regard, there is also the risk of an economic disappearance of the resource, in which a technological breakthrough renders the resource worthless as in the case of nitrates in Chile early this century. 
conclusion of the model would still be valid. This is so since it is the net present value of the resource what matters for tax and public expenditure, and any change in the path of the proceeds from the exploitation of the nonrenewable resource will only affect the pattern of the primary balance. The optimal rate of exploitation will depend on production costs and on the intertemporal path of the world price for the resource (on which the country may have an effect if it accounts for a significant share of world output and if the degree of substitutability in consumption is not too high). Given that path of extraction, however, it is still true that the more the government is concerned about future generations, the higher would be the initial surpluses (or the lower the initial deficits).

- With respect to ownership, the fact that we assume that the nonrenewable resource belongs directly to the government should not affect the results. Similar patterns for the path of the primary balance would be expected provided that, if the resource is privately exploited, the government still is able to appropriate its net present value (through for example levying royalties). ${ }^{32}$

- An important dimension assumed away in the model is that of private offsetting of public savings. The model, for simplicity, rules out explicitly bequest and intergenerational gifts, so that there is no possible offsetting. Conditions for full offsetting in savings are generally very strong, and with partial offsetting the general result for the pattern of primary balances would still be preserved since governments' intergenerational redistribution policies cannot be fully undone by private agents. $^{33}$

- Lastly, there is an important political-economy consideration not addressed by the model. This is the fact that it may be difficult for governments to resist pressures to spend when fiscal accounts are persistently in surplus. The model developed above ignores this type of issues, but it can still serve well to highlight the intergenerational implications of such pressureinduced policies, given the zero-sum nature of the problem.

${ }^{32}$ Notice that the government does not have mechanisms to fully receive initially all discounted future fiscal revenues from the nonrenewable resource, which would render the problem irrelevant, because of time-inconsistency problems.

${ }^{33}$ If government's preferences are biased toward present generations more than private agents' preferences but they can only partially offset the intergenerational-redistributing policies by increasing savings, then the government can design a path of fiscal balances which, to accomplish its objective, would have lower initial surpluses than in the case with no possible offsetting. Conversely, if the government's preferences care for future generations more than private agents' preferences, and current generations cannot borrow against the income of future ones, then the government would run larger initial surpluses than in the no-offsetting case. 


\section{References}

Auerbach A., J. Gokhale, L. Kotlikoff and E. Steigum, 1993, "Generational Accounting in Norway: Is Norway Overconsuming its Petroleum Wealth?," Boston University Working Paper (October).

Auerbach A., J. Gokhale and L. Kotlikoff., 1994, "Generational Accounting: A Meaningful Way to Evaluate Fiscal Policy," Journal of Economic Perspectives, Volume 8, No. 1 (Winter).

Blejer, M. and A. Cheasty, 1991, "The Measurement of Fiscal Deficits: Analytical and Methodological Issues," Journal of Economic Literature, 29(4) (December).

Buiter, W. H., 1990, Principles of Budgetary and Financial Policy (Cambridge, Massachusetts: MIT Press).

Chalk, N., 1998, "Fiscal Sustainability with Nonrenewable Resources," IMF Working Paper 98/26 (Washington: International Monetary Fund).

Diamond, P., 1965, "National Debt in a Neoclassical Growth Model," American Economic Review, Vol. 55, Issue 5.

Hamilton, J. and M. Flavin, 1986, "On the Limitations of Government Borrowing: A Framework for Empirical Testing," American Economic Review, Vol. 76, September.

Horne, J., 1991, "Indicators of Fiscal Sustainability," IMF Working Paper 91/5 (Washington: International Monetary Fund).

Hotelling, H., 1931, "The Economics of Exhaustible Resources," Journal of Political Economy, Volume 39, No. 2 (April).

Kotlikof, L., 1993, "From Deficit Delusion to the Fiscal Balance Rule: Looking for a Sensible Way to Measure Fiscal Policy," Journal of Economics, Supplement 7.

Liuksila, C., A. Garcia, S. Bassett, 1994, "Fiscal Policy Sustainability in Oil-Producing Countries," IMF Working Paper 94/137 (Washington: International Monetary Fund).

Samuelson, P., 1958, "An Exact Consumption-Loan Model of Interest with or without the Social Contrivance of Money," Journal of Political Economy, Vol. 66, issue 6.

Steigum E. and Ø. Thøgerson, 1995, "Petroleum Wealth, Debt Policy, and Intergenerational Welfare: The Case of Norway," Journal of Policy Modeling, 17(4). 
Wilcox, D., 1989, "Sustainability of Government Deficits: Implications of the Present-Value Borrowing Constraint," Journal of Money, Credit and Banking, Vol. 21(August).

Zee, H., 1988, "The Sustainability and Optimality of Government Debt," Staff Papers, International Monetary Fund, Vol. 35 (December). 
Figure la. Paths of Primary Deficits

Constant Government Expenditure Case

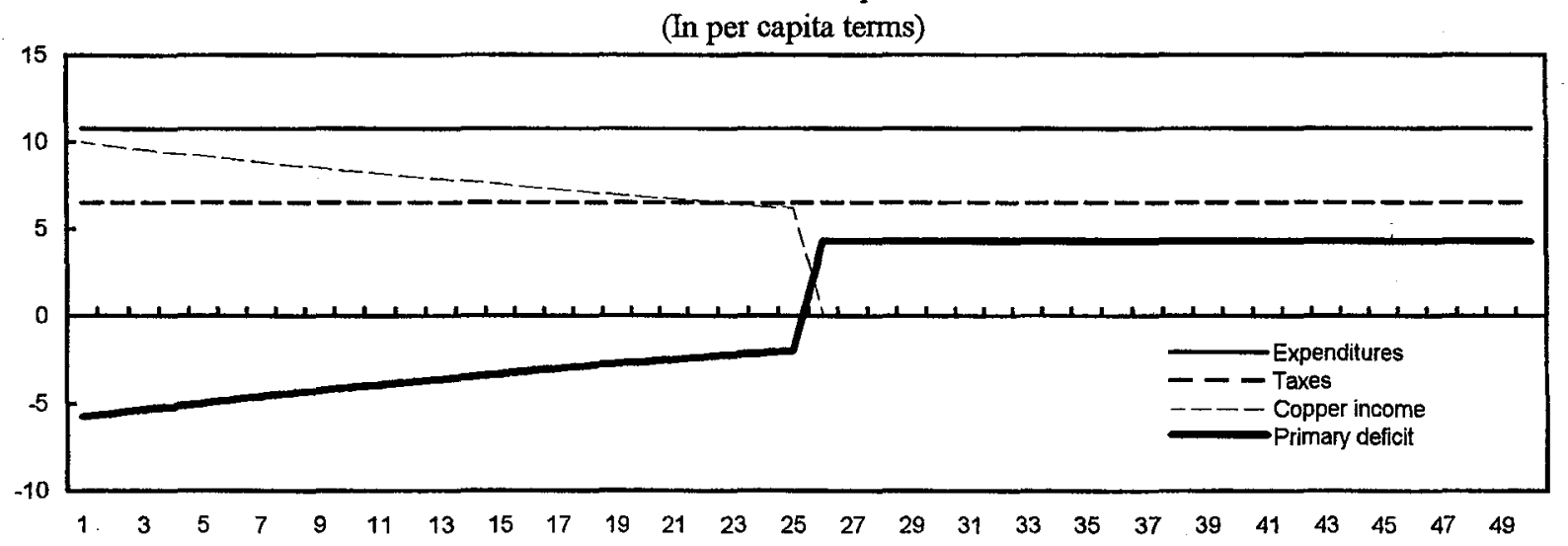

Increasing Government Expenditure Case

(In per capita terms)

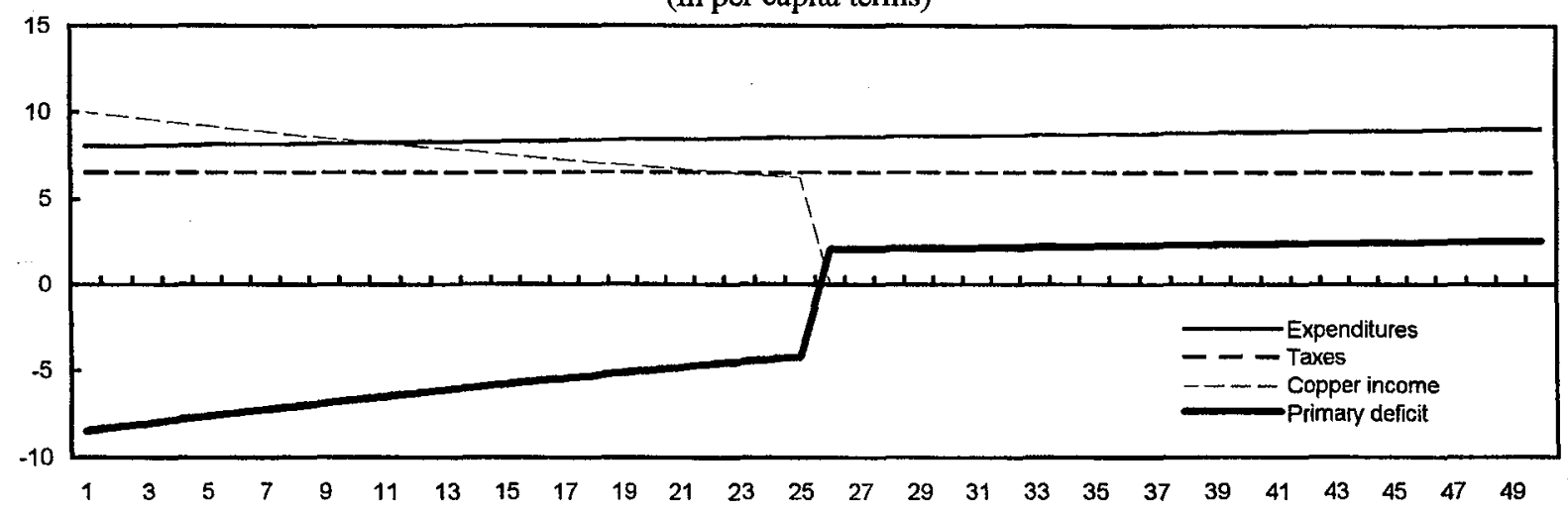

Decreasing Government Expenditure Case

(In per capita terms)

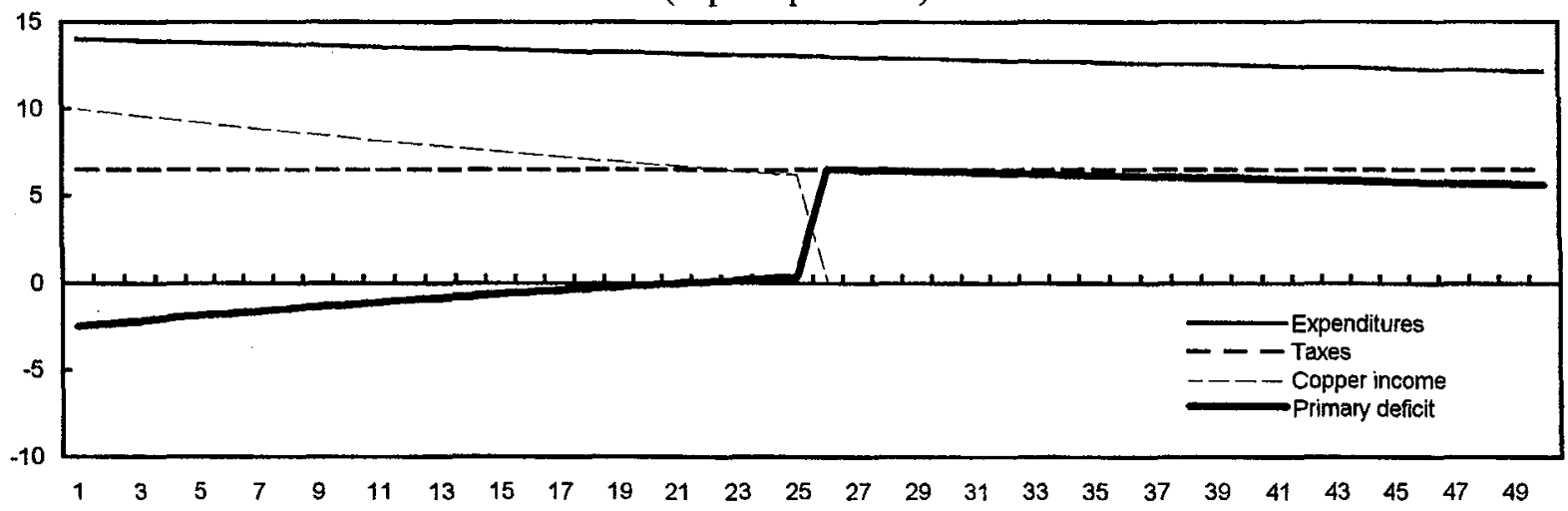


Figure 1b. Paths of Primary Deficits

Per Capita-Constant Government Expenditure Case

(In percent of GDP)

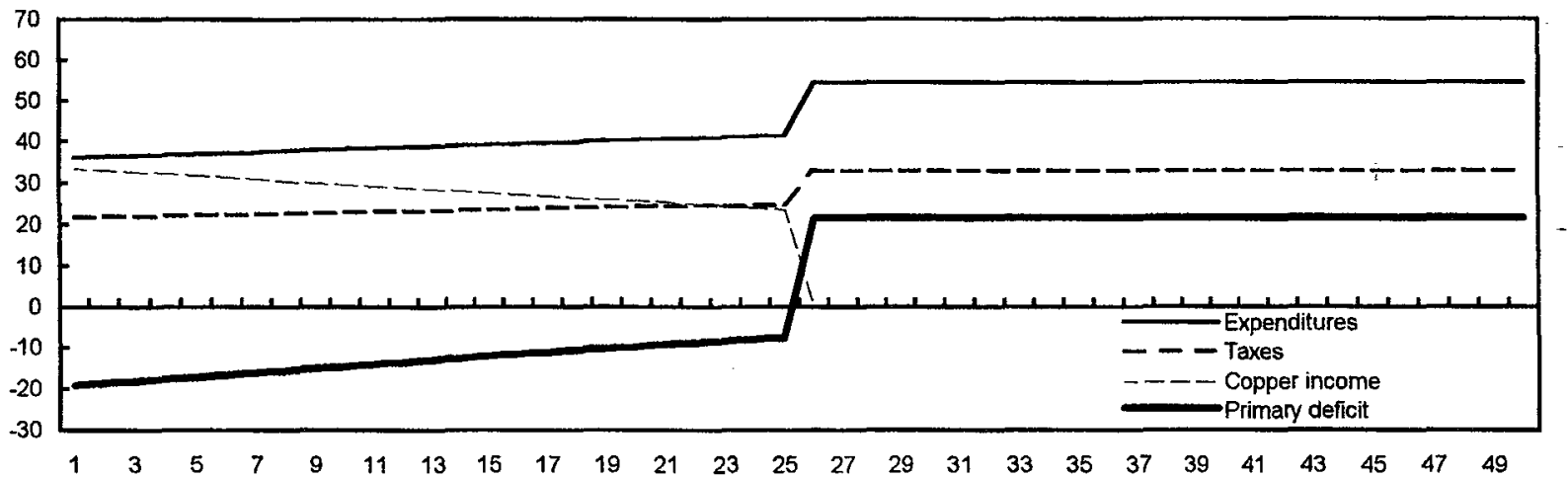

Per Capita-Increasing Government Expenditure Case

(In percent of GDP)

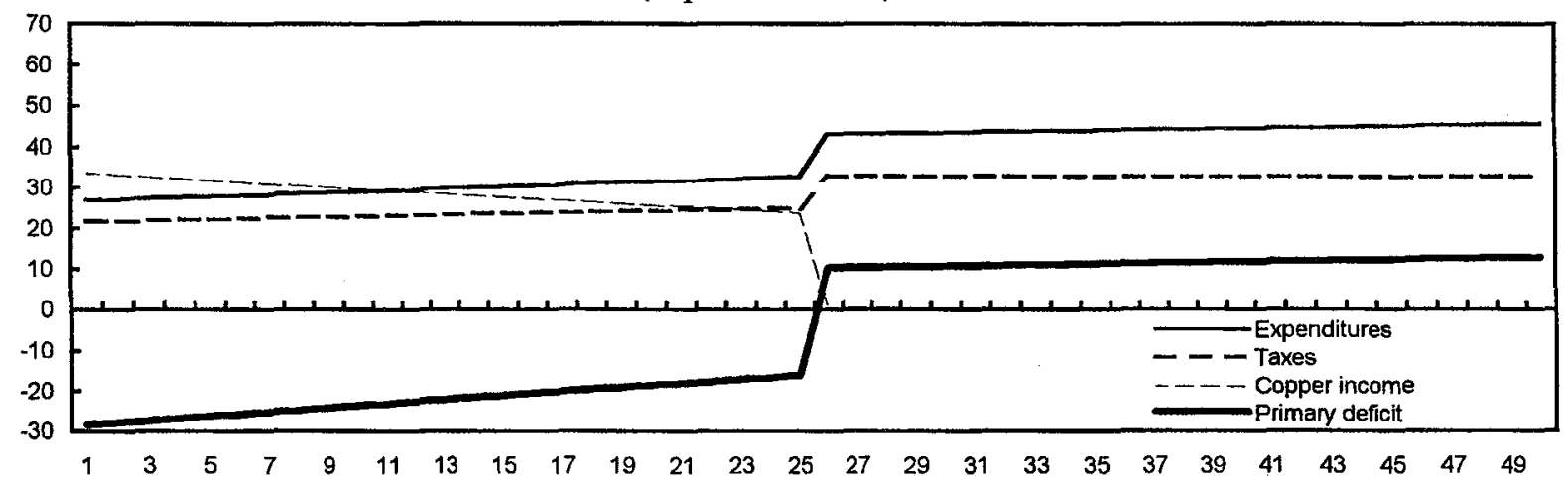

Per Capita-Decreasing Government Expenditure Case

(In percent of GDP)

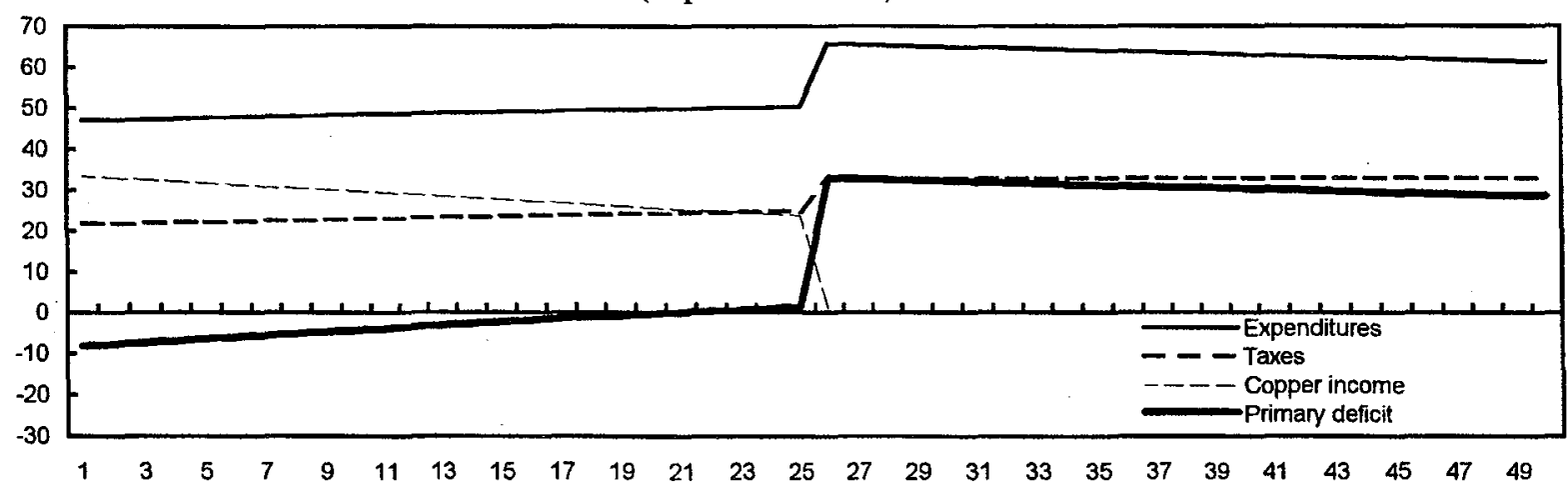


Figure 2a. Price or Volume Effect

Constant Government Expenditure Case

(In per capita terms)

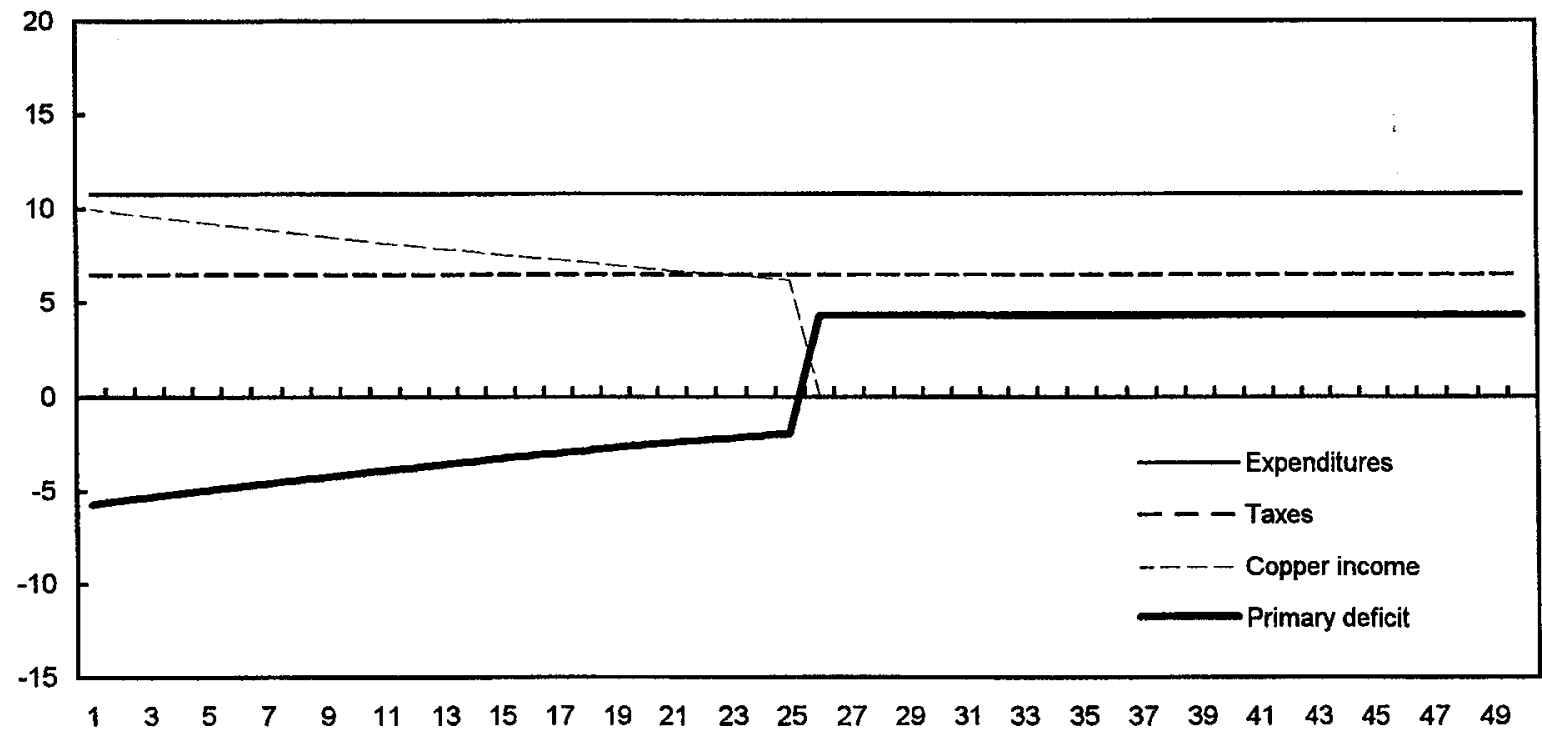

Double Endowment Size Case

(In per capita terms)

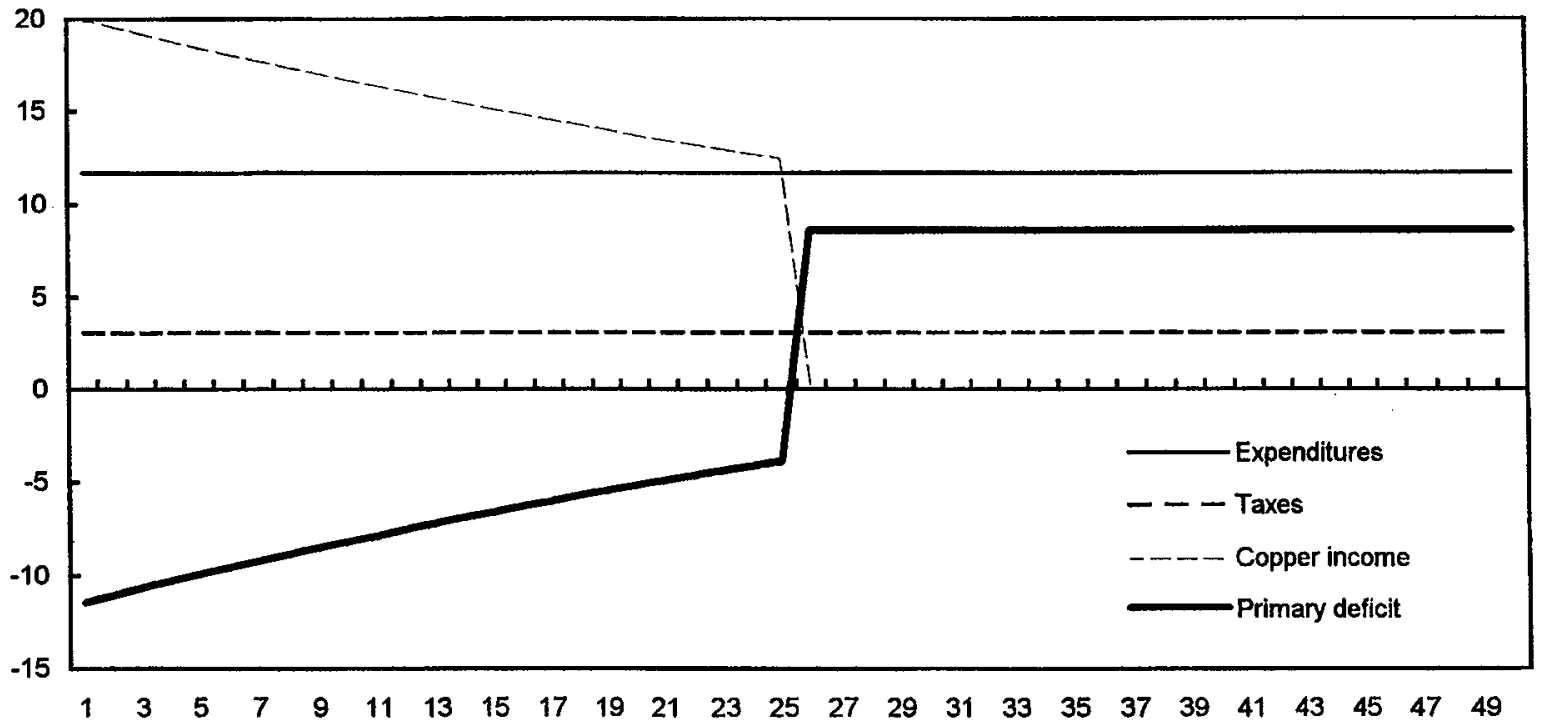


Figure 2b. Price or Volume Effect

Per Capita-Constant Government Expenditure Case

(In percent of GDP)

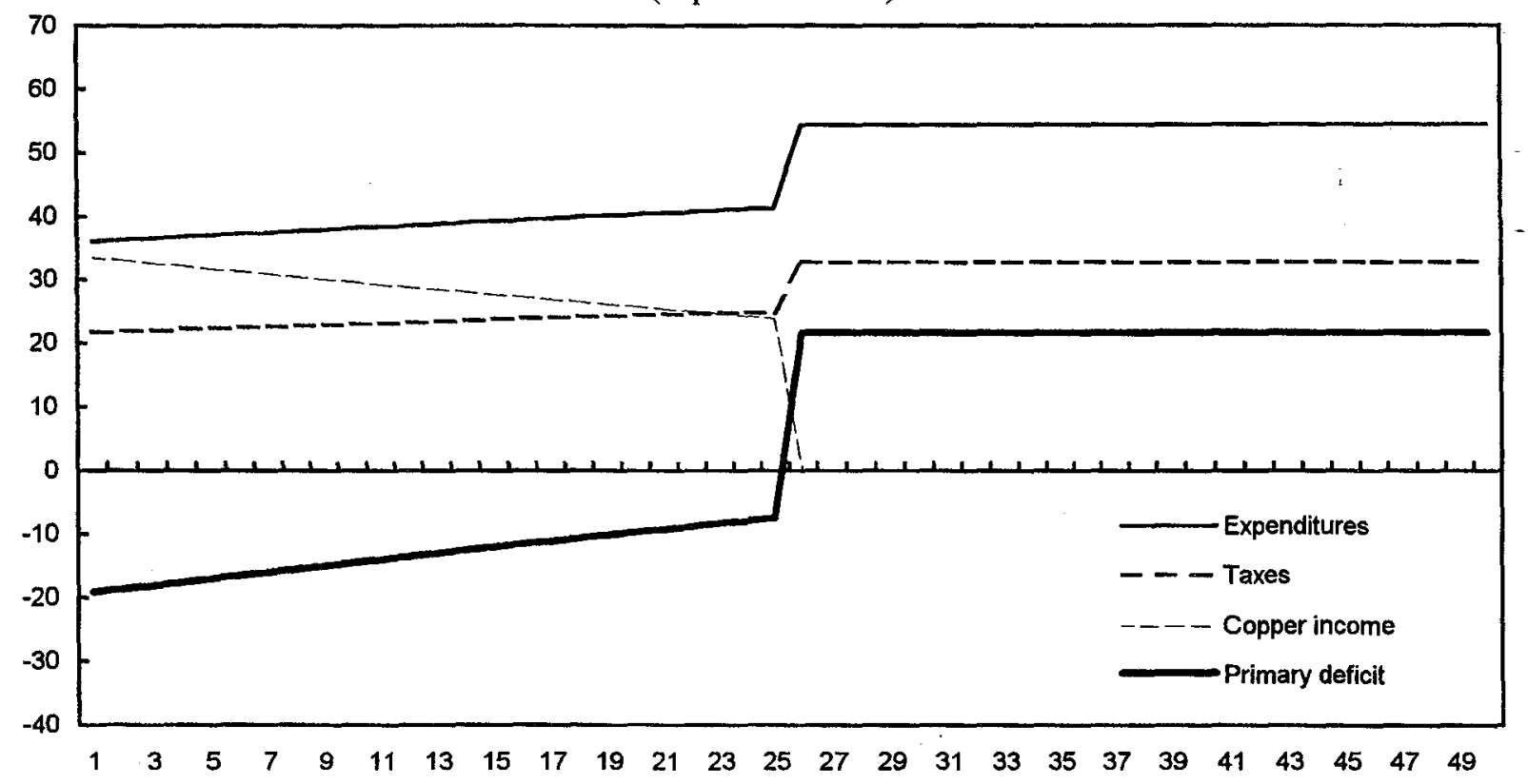

Double Endowment Size Case

(In percent of GDP)

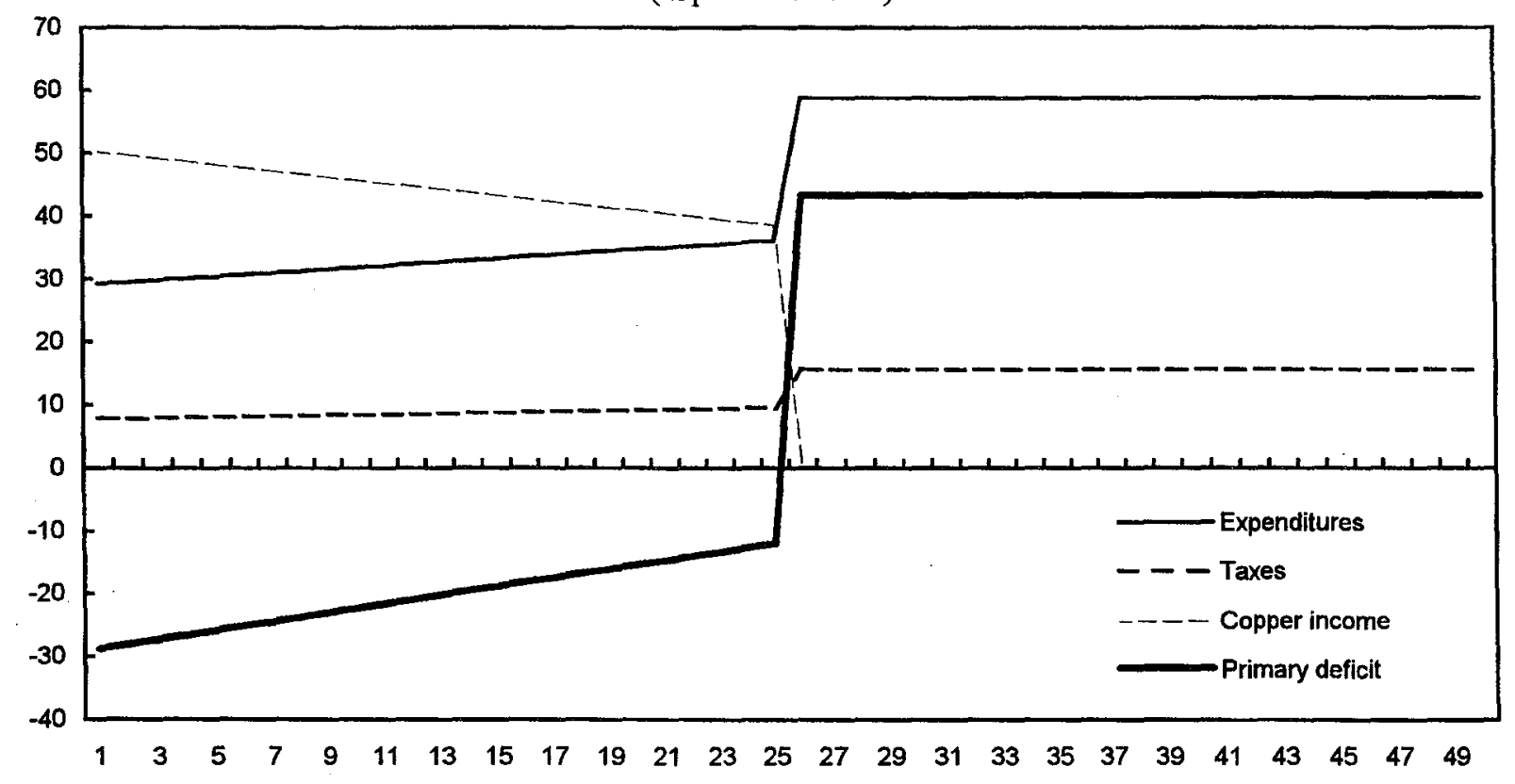


Fig. 3: Sensitivity of Constant-Expenditure Primary Deficits to Endowment Size (In per capita terms)

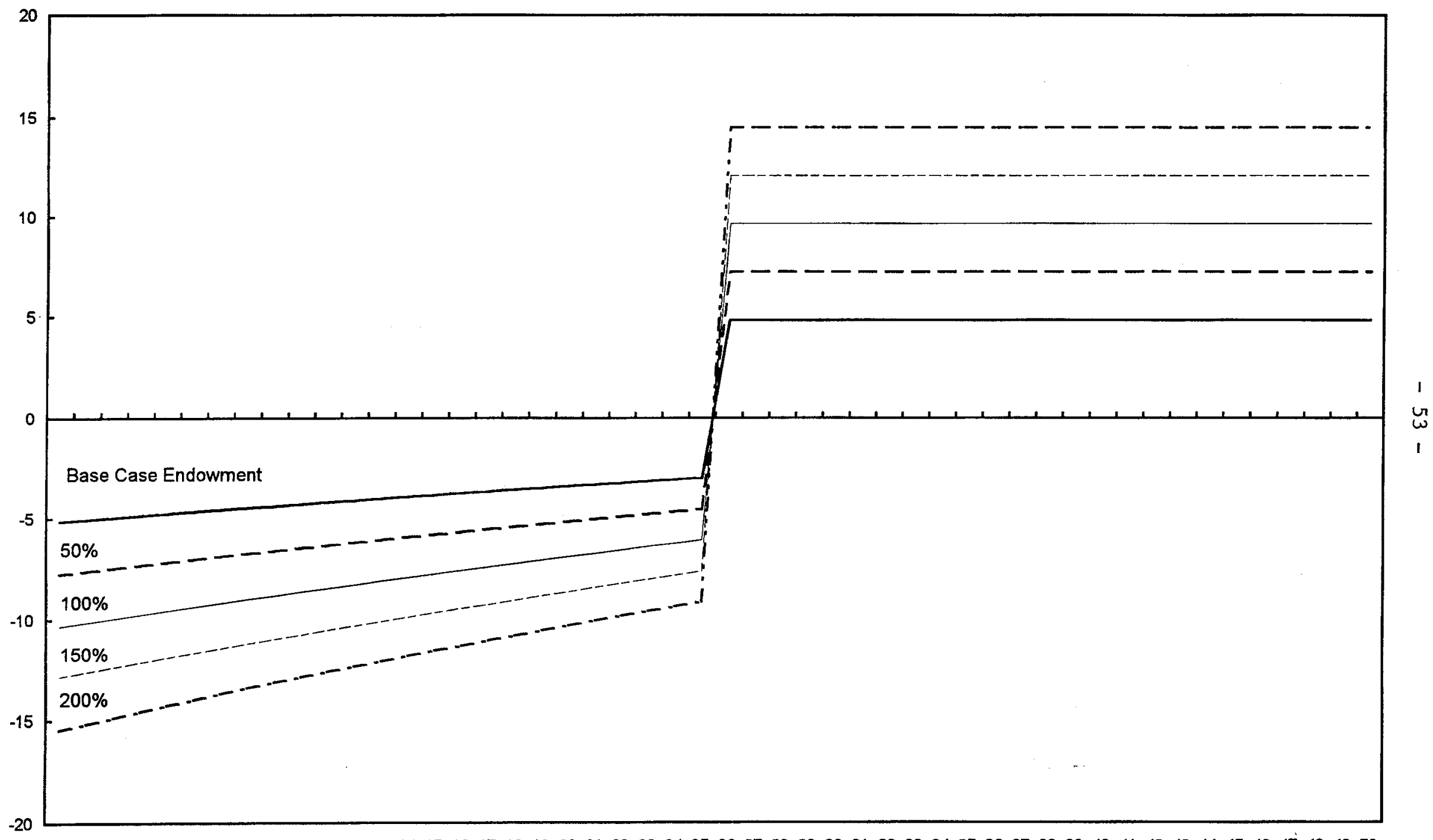

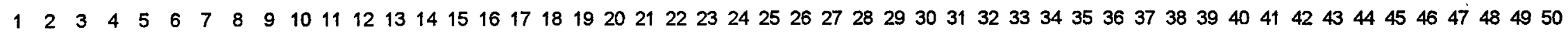




\section{Chile-A Stylized Model of Fiscal Policy with Nonrenewable Resources}

This appendix spells out in detail the framework used in Section C. We develop a simple overlapping generation (OLG) model to present more precisely the case of sustained fiscal surpluses with depletable resources, and to highlight some key underlying elements. We use a two-generation nonstochastic OLG model in which the main feature is the existence of a finite (nonrenewable) resource owned by the government which generates a temporary source of fiscal revenue. Thus, we assume an endowment economy in which each consumer receives a fix endowment and the government has a temporary endowment.

There are two consumption goods: a private good (same as the private endowment), and a public good (public expenditure). Both endowments can be internationally traded at given prices, and the government's endowment can only be exported (not consumed domestically). Both, private consumers and the government, can buy and sell foreign assets at a given international interest rate (adjusted for country risk). We assume here that the government pursues only solvent fiscal policies (no Ponzi games), and that it counts with commitment mechanisms to avoid dynamic inconsistencies.

The population grows at a constant rate $\mathbf{n}$, and the model is developed in per young terms, i.e., all variables are divided by the young population in every period. ${ }^{1}$ Capital letters denote total values in consumption good terms, small letters denote per young values, and overlined letters denote individual-agent values.

The demographics can then be portrayed as follow:

$$
\begin{array}{ll}
\eta=(1+n) & =\text { population growth factor. } \\
N_{t}^{Y} & =\text { total number of young agents in period } \mathrm{t} . \\
N_{t}^{O} & =\text { total number of old agents in period } \mathrm{t} . \\
N_{t}=N_{t}^{Y}+N_{t}^{O} & =\text { total population in period } \mathrm{t} .
\end{array}
$$

\footnotetext{
${ }^{1}$ The model is developed in per young terms for algebraic simplicity. To express the results of the model in per capita terms, the per young results need to be multiplied by the scalar $\eta /(1+\eta)$, where $\eta=(1+n)$.
} 
Which implies:

$$
\begin{aligned}
& N_{t}=\eta N_{t-1} \\
& N_{t}^{O}=\eta N_{t-1}^{O}=N_{t-1}^{Y} \\
& N_{t}^{Y}=\eta N_{t-1}^{Y} \\
& \frac{N_{t}^{Y}}{N_{t}^{O}}=\eta \quad \frac{N_{t}^{Y}}{N_{t}}=\frac{\eta}{1+\eta}
\end{aligned}
$$

\section{Consumers}

Let:

$C_{t}^{x} \quad=$ consumption of agents type $\mathrm{x}(\mathrm{x}=\mathrm{y}$-young-, $\mathrm{o}-\mathrm{old}-, \mathrm{p}$-private- $)$ in period $\mathrm{t}$.

$E_{t}^{x} \quad=$ endowment of agents type $\mathrm{x}(\mathrm{x}=\mathrm{y}, \mathrm{o}, \mathrm{p})$ in period $\mathrm{t}$.

$\beta \quad=$ intertemporal discount factor.

$A_{t}^{p} \quad=$ private sector net financial assets holdings at the end of period $\mathrm{t}-1$.

$S_{t}^{x} \quad=$ savings by agents type $\mathrm{x}(\mathrm{x}=\mathrm{y}, \mathrm{o}, \mathrm{p})$ in period $\mathrm{t}$.

Period budget constraint:

$\overline{e_{t}^{y}}-\overline{c_{t}^{y}}=\tau_{t}^{y}+\overline{a_{t+1}^{p}} \quad$ young agent.

$\overline{e_{t}^{o}}-\overline{c_{t}^{o}}=\tau_{t}^{o}-R_{t} \overline{a_{t}^{p}} \quad$ old agent.

Intertemporal budget constraint (life-time):

$\left(\overline{e_{t}^{y}}-\tau_{t}^{y}\right)+\frac{\left.\overline{\left(e_{t+1}^{o}\right.}-\tau_{t+1}^{o}\right)}{R_{t+1}}=\overline{c_{t}^{y}}+\frac{\overline{c_{t+1}^{o}}}{R_{t+1}}$ 
Net wealth definition (beginning at period $t$ ):

$$
\begin{array}{ll}
\left.\overline{n w_{t}^{y}}=\overline{\left(e_{t}^{y}\right.}-\tau_{t}^{y}\right)+\frac{\left.\overline{\left(e_{t+1}^{o}\right.}-\tau_{t+1}^{o}\right)}{R_{t+1}} & \text { young agents (NPV of disposable income) } \\
\left.\overline{n w_{t}^{o}}=\overline{\left(e_{y}^{o}\right.}-\tau_{t}^{o}\right)+R_{t} \overline{a_{t}^{p}} & \text { old agents. }
\end{array}
$$

We assume that:

a1. There is no bequest motive nor intergenerational gifts.

a2. Private agents take fiscal policy as given (i.e., no political economy considerations).

a3. Utility function is additively separable over time.

a4. Period utility function separable and logarithmic on both goods in every period.

Then the period utility function is depicted as:

$$
u\left(\overline{c_{t}^{x}}, g_{t}\right)=\ln \left(\overline{c_{t}^{x}}\right)+\ln \left(g_{t}\right) \quad \mathrm{x}=\mathrm{y}, \mathrm{o}
$$

This form of utility function implies that the path of private consumption is independent of the path of government expenditure.

Then the lifetime utility function becomes:

$$
U=u\left(\overline{c_{t}^{y}}, g_{t}\right)+\beta \overline{u\left(\overline{c_{t+1}^{o}}, g_{t+1}\right)}
$$


The old agents' problem can be stated as follows:

$$
\begin{gathered}
\left.\operatorname{Max} u \overline{u\left(c_{t}^{o}\right.}, g_{t}\right) \\
\text { s.t. } \overline{c_{t}^{o}}=\overline{m w_{t}^{\circ}} \\
\text { given } g_{t}
\end{gathered}
$$

The solution to this problem is:

$$
\begin{aligned}
& \overline{c_{t}^{o}}=\overline{n w_{t}^{o}} \\
& \left.\overline{s_{t}^{o}}=\overline{a_{t}^{p}}=\left(R_{t}-1\right) \overline{a_{t}^{p}}+\overline{\left(e_{t}^{o}\right.}-\tau_{t}^{o}\right)-\overline{c_{t}^{o}}
\end{aligned}
$$

The young agents' problem is:

$$
\begin{aligned}
& \operatorname{Max} u\left(\overline{c_{t}^{y}}, g_{t}\right)+\beta u\left(\overline{c_{t+1}^{o}}, g_{t+1}\right) \\
& \text { s.t. } \overline{c_{t}^{y}}+\frac{\overline{c_{t+1}^{o}}}{R_{t+1}}=\overline{n w_{t}^{y}} \\
& \text { given } g_{t}, g_{t+1}
\end{aligned}
$$

The solution to this problem is:

$$
\begin{aligned}
& \overline{c_{t+1}^{o}}=\beta R_{t+1} \overline{c_{t}^{y}} \\
& \overline{c_{t}^{y}}=\frac{1}{1+\beta} \overline{m w_{t}^{y}} \\
& \overline{c_{t+1}^{o}}=R_{t+1} \frac{\beta}{1+\beta} \overline{n w_{t}^{y}}=\overline{n w_{t+1}^{o}} \\
& \left.\overline{s_{t}^{y}}=\overline{a_{t+1}^{p}}=\overline{\left(e_{t}^{y}\right.}-\tau_{t}^{y}\right)-\overline{c_{t}^{y}}
\end{aligned}
$$


Aggregating (in per young terms) yields the following functions:

\section{Consumption:}

$$
c_{t}=\overline{c_{t}^{y}}+\frac{\overline{c_{t}^{o}}}{\eta}=\frac{1}{1+\beta} \overline{n w_{t}^{y}}+\frac{1}{\eta} \overline{m w_{t}^{o}}
$$

Saving:

$$
s_{t}^{p}=\overline{s_{t}^{y}}+\frac{\overline{s_{t}^{o}}}{\eta}=\overline{a_{t+1}^{p}}-\frac{a_{t}^{p}}{\eta}=\frac{\beta}{1+\beta} \overline{m w_{t}^{y}}-\frac{1}{\eta} \overline{a_{t}^{p}}
$$

\section{The government}

Let:

$G_{t} \quad=$ government expenditure (public good) in period $t$.

$E_{t}^{g} \quad=$ government's endowment in period t.

$A_{t}^{g} \quad=$ government's net financial assets position at the end of period t-1.

$T_{t} \quad=$ total tax revenue in period $\mathrm{t}$

$\tau_{t}^{Y} \quad=$ lump sum tax levied on each young agents in period $\mathrm{t}$.

$\tau_{T}^{O} \quad=$ lump sum tax levied on each old agents in period $\mathrm{t}$.

$p_{t} \quad=$ international price of the government's endowment.

$\mathrm{T} \quad=$ number of periods during which the government receives the endowment. 
The temporariness of the government's endowment can be depicted as:

$$
\begin{array}{ll}
E_{i}^{g}>0 & \forall i \leq t+\mathrm{T}-1 \\
E_{i}^{g}=0 & \forall i>t+\mathrm{T}-1
\end{array}
$$

Total tax revenue in period $t$ can be expressed by:

$$
\begin{array}{ll}
T_{t}=N_{t}^{Y} \tau_{t}^{Y}+N_{t}^{O} \tau_{t}^{O} & \\
t_{t}=\tau_{t}^{Y}+\frac{\tau_{t}^{O}}{\eta} & \text { in per young terms }
\end{array}
$$

The government's nonfinancial wealth at the end of period $t-1$ is defined by:

$$
\begin{aligned}
& \sum_{i=t}^{\infty} Q_{i}^{t-1} E_{i}^{g} p_{i}=\sum_{i=t}^{t-1+\mathrm{T}} Q_{i}^{t-1} E_{i}^{g} p_{i}=N F W_{i}^{g} \\
& \sum_{i=t}^{\infty} Q_{i}^{t-1} \eta^{i-(t-1)} e_{i}^{g} p_{i}=\sum_{i=t}^{t-1+\mathrm{T}} Q_{i}^{t-1} \eta^{i-(t-1)} e_{i}^{g} p_{i}=n f w_{i}^{g} \quad \text { in per young terms } \\
& \eta^{1-t} \sum_{i=t}^{\infty} Q_{i}^{t-1} \eta^{i} e_{i}^{g} p_{i}=\eta^{1-t} \sum_{i=t}^{t-1+\mathrm{T}} Q_{i}^{t-1} \eta^{i} e_{i}^{g} p_{i}=n f w_{i}^{g}
\end{aligned}
$$

Where:

$$
\begin{aligned}
& R_{t}=\left(1+r_{t}\right) \\
& =\text { international interest factor on one-period bonds } \\
& \text { maturing in period } \mathrm{t} \text {. } \\
& Q_{f}^{t}=1 \quad \text { for } f=t \quad \quad=\text { present value in period } t \text { of a unit of good } \\
& Q_{f}^{t}=\frac{1}{\prod_{\nu=t+1}^{f} R_{v}} \quad \text { for } f \geq t \\
& \text { delivered in period } \mathrm{f} \text {. }
\end{aligned}
$$


The government's intertemporal budget constraint, assuming away Ponzi games and beginning at period $t$, is defined by:

$R_{t}\left[A_{t}^{g}+N F W_{t}^{g}\right]+\sum_{i=t}^{\infty} Q_{i}^{t} T_{i}=\sum_{i=t}^{\infty} Q_{i}^{t} G_{i}$

$R_{t}\left[a_{t}^{g}+n f w_{t}^{g}\right]+\sum_{i=t}^{\infty} Q_{i}^{t} \eta^{i-t} t_{i}=\sum_{i=t}^{\infty} Q_{i}^{t} \eta^{i-t} g_{i} \quad$ in per young terms

$R_{t}\left[a_{t}^{g}+n f w_{t}^{g}\right]=\eta^{-t} \sum_{i=t}^{\infty} Q_{i}^{t} \eta^{i}\left(g_{i}-t_{i}\right)$

These equations, in absolute and per young terms, state the well-known condition that the present value of primary budget deficits must equal the initial total wealth of the government, including its nonfinancial wealth which in this case comprises only the government's temporary endowment.

In presence of finite resources, one could think of alternative definitions for the primary budget deficit. A conventional fiscal accounting definition would include the receipts from the nonrenewable resource as income; while an economic definition should exclude the proceeds of the resource, regarding them as a below-the-line asset management decision. These can then be expressed as:

$$
\begin{array}{ll}
\left(G_{t}-T_{t}\right) & \text { economic definition. } \\
\left(G_{t}-T_{t}\right)-E_{t}^{g} p_{t} & \text { fiscal account definition. }
\end{array}
$$

The implication of distinguishing between such definitions is clear: conventional fiscal accounts understate the economic version of the primary budget deficit during those periods in which the government receives the proceeds from the endowment.

Similarly, government savings can be defined in an analogous fashion:

$$
\begin{array}{ll}
\left(R_{t}-1\right)\left[A_{t}^{g}+N F W_{t}^{g}\right]+\left(T_{t}-G_{t}\right) & \text { economic definition. } \\
\left(R_{t}-1\right) A_{t}^{g}+E_{t}^{g} p_{t}+\left(T_{t}-G_{t}\right) & \text { fiscal accounts definition. }
\end{array}
$$


These two definitions highlight an important difference. While the economic definition treats as income only the interest-equivalent component of the nonfinancial wealth, the fiscal account definition considers as revenue the full amount of proceeds from the nonrenewable resource. This portrays clearly that conventional accounting regards as income a share of proceeds that would otherwise be considered as a below-the-line operation. In this vein, government savings are overstated in the conventional fiscal accounts with respect to the economic accounting since:

$E_{t}^{g} p_{t}>\left(R_{t}-1\right) N F W_{t}^{g}$

In other words, the inequality above shows that these two definitions would coincide only if the government's endowment were a perpetual annuity (assuming constant endowment prices), which is precisely what was ruled out when considering a finite resource.

\section{Welfare function}

We assume that:

a5. Welfare weights decrease over time but are equal across contemporaneous generations.

a6. The government chooses a path of taxes and public expenditures to maximize welfare.

Then the government's problem is:

$$
\begin{aligned}
\operatorname{Max} & \sum_{i=t}^{\infty} \phi_{i}\left[N_{i}^{y} u\left(\overline{c_{i}^{y}}, g_{i}\right)+N_{i}^{o} u\left(\overline{c_{i}^{o}}, g_{i}\right)\right] \\
& =\eta^{-(t+1)} N_{t}^{y} \sum_{i=t}^{\infty} \phi_{i} \eta^{i}\left[\eta \ln \left(\overline{c_{i}^{y}}\right)+\ln \left(\overline{c_{i}^{o}}\right)+(1+\eta) \ln \left(g_{i}\right)\right] \\
\text { s.t. } \quad & R_{t}\left[a_{t}^{g}+n f w_{t}^{g}\right]=\eta^{-t} \sum_{i=t}^{\infty}{Q_{i}^{t}}^{t} n^{i}\left(g_{i}-t_{i}\right) \\
& t_{t}=\tau_{t}^{y}+\frac{\tau_{t}^{o}}{\eta} \\
& \overline{c_{t}^{y}}=\frac{1}{1+\beta}\left[\left(e_{t}^{y}-\tau_{t}^{y}\right)+\frac{\left(e_{t+1}^{o}-\tau_{t+1}^{o}\right)}{R_{t+1}}\right] \\
& \overline{c_{t}^{o}}=\frac{\beta}{1+\beta}\left[R_{t}\left(e_{t-1}^{y}-\tau_{t-1}^{y}\right)+\left(e_{t}^{o}-\tau_{t}^{o}\right)\right]
\end{aligned}
$$




\section{A stylized application:}

For the sake of exposition and to reduce the dimensionality of the problem some simplifying assumptions are used, namely:

a7. Interest rates are constant over time.

a8. The government's temporary endowment is constant over the lapse it exists.

a9. The price of the government's endowment is constant over time.

a10. Levied lump sum taxes are constant over time and across generations in every period.

Assumption a7 implies:

$Q_{i}^{t}=R^{t-i}$

Assumptions a7, a8 and a9 imply:

$N F W_{t}^{g}=\sum_{i=t}^{t-1+T} Q_{i}^{t-1} E_{i} p_{i}=R \frac{1-R^{-T}}{R-1} E p$

$n f w_{t}^{g}=R \frac{1-R^{-\mathrm{T}}}{R-1} \frac{E p}{N_{t}^{Y}} \quad$ in per young terms

Assumption a10 implies:

$t_{t}=\tau \frac{1+\eta}{\eta}$

The assumption that lump sum taxes are constant over time allows to emphasize the issue of sustainability in the per capita provision of the public good. That is, for the same tax burden per capita, what path of the primary fiscal stance would permit, for example, a constant or increasing provision of the public good? 
Thus, the welfare maximization problem becomes:

$\operatorname{Max} \eta^{-(t+1)} N_{t}^{y} \sum_{i=t}^{\infty} \phi_{i} \eta^{i}\left[\eta \ln \left(\overline{c_{i}^{y}}\right)+\ln \left(\overline{c_{i}{ }^{\circ}}\right)+(1+\eta) \ln \left(g_{i}\right)\right]$

s.t. $\quad R\left(a_{t}^{g}+\left(R \frac{1-R^{-T}}{R-1}\right) \frac{E p}{N_{t}^{Y}}\right)=\sum_{i=t}^{\infty}\left(\frac{\eta}{R}\right)^{i-t}\left(g_{i}-\left(\frac{1+\eta}{\eta}\right) \tau\right)$

$\overline{c_{i}^{y}}=\frac{1}{1+\beta}\left[\left(\frac{R+1}{R}\right)(e-\tau)\right]$

$\overline{c_{i}^{0}}=\frac{\beta}{1+\beta}[(R+1)(e-\tau)]$

$\overline{c_{t}^{0}}=\frac{\beta}{1+\beta}\left[(R+1) e-\left(R \tau_{t-1}+\tau\right)\right]$

given $\tau_{t-1}, a_{t}^{g}, N_{t}^{Y}$

Solving for $g_{i}$ and $\tau$ yields the following close-form solution:

$$
\begin{aligned}
g_{i+1}= & R \frac{\phi_{i+1}}{\phi_{i}} g_{i} \\
\tau= & \frac{1}{2}\left[e-k_{0} \frac{\eta}{(1+\eta)}\left[\sum_{i=t}^{\infty}\left(\frac{\eta}{R}\right)^{i-t}\right]^{-1}\right] \\
k_{0}= & R_{t} a_{t}^{g}+\left(R^{2} \frac{1-R^{-\mathrm{T}}}{R-1}\right) \frac{E p}{N_{t}^{Y}} \\
g_{i}= & R^{i-t} \frac{\phi_{i}}{\phi_{t}} \frac{1}{2}\left[e \frac{(1+\eta)}{\eta} \sum_{i=t}^{\infty}\left(\frac{\eta}{R}\right)^{i-t}+k_{0}\right]\left[\sum_{i=t}^{\infty} \eta^{i-t} \frac{\phi_{i}}{\phi_{t}}\right]^{-1} \\
d_{i}^{F D}= & R^{i-t} \frac{\phi_{i}}{\phi_{t}} \frac{1}{2}\left[e \frac{(1+\eta)}{\eta} \sum_{i=t}^{\infty}\left(\frac{\eta}{R}\right)^{i-t}+k_{0}\right]\left[\sum_{i=t}^{\infty} \eta^{i-t} \frac{\phi_{i}}{\phi_{t}}\right]^{-1} \\
& -\frac{1}{2} \frac{(1+\eta)}{\eta}\left[e-k_{0} \frac{\eta}{(1+\eta)}\left[\sum_{i=t}^{\infty}\left(\frac{\eta}{R}\right)^{i-t}\right]^{-1}\right]-\frac{E^{g} p}{\eta^{i-t} N_{t}^{Y}} \quad \text { iff } i \leq \mathrm{T}+t
\end{aligned}
$$

Primary

fiscal deficit

(fiscal accounting) 
The solution above presents three different cases depending on the term $\mathbf{R} \phi_{i+l} / \phi_{i}$, which reflects the government's relative time-preference of people's welfare adjusted by the opportunity cost of spending an extra unit today:

i. If $\mathrm{R} \phi_{i+1} / \phi_{i}>1$, then government expenditure per young (and per capita) increases over time, reflecting its relative care for future generations.

ii. If $\mathrm{R} \phi_{i+l} / \phi_{i}=1$, i.e., if the government seeks intergenerational equity, then its expenditure per young (and per capita) is constant over time.

iii. If $\mathrm{R} \phi_{i+1} / \phi_{i}<1$, then government expenditure per young (and per capita) diminishes over time because the adjusted generational preference is biased toward present and near-future generations.

If government intertemporal preferences evolve smoothly, so will government expenditure in all of the cases above. As mentioned in Section $\mathrm{C}$, these three cases are depicted in Figure 1a (in per capita terms) and Figure $1 \mathrm{~b}$ (in percent of GDP). The paths of primary fiscal deficits, in the conventional fiscal accounting sense, show in general an initial primary surplus, ${ }^{2}$ i.e., the replacement of nonfinancial wealth with financial assets. The accumulation of financial assets implies higher future interest income and thus the ability to run primary deficits. Case $i$ and $i$ show a clear pattern of primary surplus when the finite resource exists and primary deficits thereafter. Case iii shows an inverted $u$-shape path for the primary deficit.

Moreover, as illustrated in these figures, the less biased government preferences are toward present generations the higher the initial surpluses. Conversely, initially weaker primary fiscal stances, ceteris paribus, show implicitly the government's relative disinterest for the future generations, highlighting the intergenerational implications of policies, i.e., lower primary deficits in the future and a lower provision of the public good.

Furthermore, counter to some casual views that a larger depletable resource would merit less an initial surpluses (because it would resemble more closely a permanent resource); we found, as displayed in Figure $2 a$ and $2 b$, that as long as the resource is finite the larger its size the higher the optimal initial primary surplus in all cases. Also, Figure 3 shows, for the per capita constant expenditure case, that the initial per capita surplus moves equiproportionally with the present value of the endowment, i.e., the percentage increase in the primary surplus is the same as that of the endowment. ${ }^{3}$

${ }^{2}$ See Appendix II for initial conditions.

${ }^{3}$ The per capita increasing expenditure case shows a less than proportional percentage increase in the initial surplus, while the expenditure decreasing case exhibits a more than proportional percentage increase. 


\section{Chile-Initial Conditions for Initial Primary Surpluses}

Assume $R>\eta$

Let $\Phi_{i}=\phi^{i-t}$ with $0<\phi<1$

$d_{t}^{F D}<0 \quad$ iff $a_{t}^{g}<\frac{E^{g} p}{N_{t}^{Y}} \frac{2}{\theta_{2}} \frac{1}{R}-\frac{1}{\theta_{2}} \frac{1}{R} e \frac{(1+\eta)}{\eta} \theta_{1}-R \frac{\left(1-R^{-T}\right)}{(R-1)} \frac{E^{g} p}{N_{t}^{Y}}$

Where:

$\theta_{1}=\frac{R}{(R-\eta)}(1-\eta \phi)-1$

$\theta_{2}=\frac{(R-\eta)}{R}+(1-\eta \phi)$

Case $i i: R \frac{\Phi_{i+1}}{\Phi_{i}}=R \phi=1$

$\theta_{1}=0$

$\theta_{2}=2 \frac{(R-\eta)}{R}$

$d_{t}^{F D}<0 \quad$ iff $a_{t}^{g}<\frac{E^{g} p}{N_{t}^{Y}} \frac{1}{(R-\eta)}-R \frac{\left(1-R^{-T}\right)}{(R-1)} \frac{E^{g} p}{N_{t}^{Y}}=\frac{E^{g} p}{N_{t}^{Y}} \frac{1}{(R-\eta)}-\frac{1}{R} N F W_{t}=\theta_{3}$

Since $\frac{E^{g} p}{N_{t}^{Y}}>(R-1) N F W_{t}$ then $\theta_{3}>0$

Thus, in the per capita constant expenditure case, as long as the initial stock of financial assets is not too large the initial fiscal primary balance will be in surplus. 
Case $i: R \frac{\Phi_{i+1}}{\Phi_{i}}=R \phi>1$

$\theta_{1}<0$

$0<\theta_{2}<2 \frac{(R-\eta)}{R}$

$d_{t}^{F D}<0 \quad$ iff $a_{t}^{g}<\frac{E^{g} p}{N_{t}^{Y}} \frac{2}{\theta_{2}} \frac{1}{R}-\frac{1}{\theta_{2}} \frac{1}{R} e \frac{(1+\eta)}{\eta} \theta_{1}-R \frac{\left(1-R^{-T}\right)}{(R-1)} \frac{E^{g} p}{N_{t}^{Y}}=\theta_{3}^{*}$

Where:

$\theta_{3}^{*}>\theta_{3}>0$

Then the per capita increasing expenditure case will have initial fiscal surpluses even under a larger stock of initial financial assets than in the constant expenditure case.

Case iii: $R \frac{\Phi_{i+1}}{\Phi_{i}}=R \phi<1$

$\theta_{1}>0$

$\theta_{2}>2 \frac{(R-\eta)}{R}>0$

$d_{t}^{F D}<0 \quad$ iff $a_{t}^{g}<\frac{E^{g} p}{N_{t}^{Y}} \frac{2}{\theta_{2}} \frac{1}{R}-\frac{1}{\theta_{2}} \frac{1}{R} e \frac{(1+\eta)}{\eta} \theta_{1}-R \frac{\left(1-R^{-T}\right)}{(R-1)} \frac{E^{g} p}{N_{t}^{Y}}=\theta_{3}^{* *}$

Where:

$\theta_{3}^{* *}<\theta_{3}$

The per capita decreasing expenditure case supports initial primary surpluses under more restricted conditions than the constant or decreasing expenditure cases, i.e., smaller initial stocks of financial assets could call for initial deficits, since the future reduction in per capita expenditures will determine future surpluses permitting early transitory deficits. 


\section{CAPITAL ACCOUNT RESTRICTIONS IN CHILE IN THE 1990s ${ }^{34}$}

Abstract
This paper examines the Chilean experience with controls on capital flows and reviews a
number of studies on controls on capital inflows. It seems that controls on capital inflows
had only a short-term impact in reducing specific inflows before a shift of transactions on
the capital account to untaxed inflows occurred. Avoidance by migration via the
disintermediation of the taxed domestic banking system may have also been important. The
studies reviewed conclude that: there is some evidence that the URR has been successful in
increasing domestic interest rates; there is a relatively weaker evidence that the URR has
reduced the magnitude of capital inflows into Chile and altered the composition of capital
inflows in favor of medium- and long-term capital inflows; and there is actually no evidence
that the URR affected the level of the real exchange rate. However, these studies contain
both important methodological problems in measuring net capital inflows and short-term
capital inflows into Chile, as well as some econometric problems. Also, most of them have
not controlled for the relaxation of regulations affecting capital outflows during the 1990s,
for the effect of sterilization operations by monetary authorities on domestic real interest
rates, or for foreigners' willingness to lend. These problems may have biased the estimates
either in favor or against the hypothesis that controls have been effective. Moreover, as no
study has assessed empirically the eventual welfare benefits and costs of the controls, it is
not possible to judge the net effect of the URR on welfare.

\section{A. The Problem}

77. Nearly two decades ago, Tobin aired in his presidential address to the Eastern Economic Association the idea of taxing international capital flows to reduce exchange rate volatility and to preserve and promote the autonomy of national macroeconomic policy. ${ }^{35}$ The crises of the European Monetary System in 1992 and 1993, of Mexico in 1994-95 together with the recent Asian crisis, have prompted calls from policy making circles and from some

\footnotetext{
${ }^{34}$ Prepared by Francisco Nadal-De Simone and Piritta Sorsa. We are grateful to Nicolas Eyzaguirre, Saul Lizondo, Klaus Schmidt-Hebbel, and Chilean officials for providing comments and suggestions.
}

${ }^{35}$ According to Tobin, the tax rate could be a fixed percent per year (proposals in the literature range from 0.5 percent to 0.05 percent) which falls as maturity increases. 
members of the economic profession to control cross-country capital flows. ${ }^{36}$ The renewed interest in taxing capital flows follows from growing interest on the costs and benefits of capital flows and of government policies designed to limit or modify their composition. The Bank for International Settlements (BIS) indicates that more than 40 percent of all foreign exchange transactions have a maturity of two days or less with about 80 percent of all foreign exchange transactions involving "round trips" of seven days or less. Many observers, e.g., Eichengreen and Wyploz as well as Frankel (1996), believe that much of that trade has little to do with "fundamentals," is destabilizing and reduces welfare. ${ }^{37}$ Therefore, following that argument, a Tobin tax that curbs welfare-reducing short-term capital flows without affecting . welfare-enhancing long-term flows, should represent a Pareto improvement.

78. The reasons generally advanced for restricting capital flows fall into three categories: ${ }^{38}$

- As indicated by the Mundell-Fleming model, monetary policy efficacy (in creating a wedge between domestic and foreign interest rates) is much reduced in a world of fast asset market adjustment and high substitutability between domestic and foreign currency denominated assets. Capital controls would preserve and perhaps expand the autonomy of monetary policy.

- Given the distortions to the competitive equilibrium such as private investors motivated by noise trading, band wagons and bubbles-what Frankel calls pathological speculation-or implicit government guarantee of banks' external liabilities, capital flows can be welfarereducing. Controlling them would restore the first best.

- Given that multiple equilibria are possible, capital controls could help either in keeping the "good" equilibrium, or in moving the economy to a relatively higher welfare equilibrium.

${ }^{36}$ Eichengreen, Tobin, and Wyplosz (1995) resurfaced Tobin's arguments for a global tax on currency transactions as a way of coping with possible speculative attacks during Stage II of the Maastricht process toward European monetary union that could otherwise derail such process.

${ }^{37}$ One major reason for that belief is that current models of exchange rate determination based on fundamentals do not outperform "naive models" such as the random walk model. The reasons for that poor performance are to be found in both specification and estimation problems (Meese, 1990). Nadal-De Simone and Razzak (1998) show that once some of those problems are addressed, the performance of a standard model of exchange rate determination improves significantly and the model beats the random walk model.

${ }^{38}$ In Haq et al. (1996), it is also argued that the globalization of trade and production is eroding the tax base of national governments at the same time that more problems are becoming global. This problem could be addressed by taxing international economic activities to generate an international flow of revenue to deal with those global problems. 
Therefore, arguments for "throwing sand in the wheels of international finance" will invariably have as common elements among them the assumption of departure from the competitive equilibrium or "market failure," and the assumption that restrictions on capital flows will thus be welfare-enhancing.

79. Like other countries in Latin America and Asia, Chile faced a surge in capital inflows at the beginning of the 1990s. According to Zahler (1997), the most important dilemma faced by policymakers in the 1990s in Chile was that internal balance required interest rates higher than abroad - at a time in which Chile faced a decreasing country risk and expectations of currency revaluation-while external balance was inconsistent with the appreciation of the currency. The authorities favored the introduction of controls on capital inflows to offset, or at least moderate, the appreciation of the currency while keeping the interest rate differential required for reducing the excess of desired expenditure over output. Therefore, Chilean controls on capital flows have the objectives of "reducing potential effects on macroeconomic stability, increasing the effectiveness of monetary policy, and imposing prudential regulations on banks and institutional investors" (Le Fort and Budnevich, 1996), and as such their rationale is to be found in the three usual reasons advanced for capital controls which were discussed above.

80. In the 1990s, regulations in Chile affecting both capital inflows and capital outflows were significantly altered. The main control on inflows has been an asymmetric Tobin tax, the one-year unremunerated reserve requirement (URR), or encaje, imposed in 1991 on foreign loans and fixed-income securities. Although the URR was initially aimed at debt-instruments, its coverage was later extended to certain portfolio and some foreign direct investment (FDI) flows. Between 1991 and 1997, the coverage of the URR was widened and the rate of the URR increased. At present, the URR has been suspended-its rate is zero percent. In contrast, controls on capital outflows were relaxed during the 1990s. The authorities reduced the minimum stay period for foreign investment in Chile; increased the maximum share of foreign assets in total assets that commercial banks, pension funds and mutual funds are allowed to hold; and liberalized outward FDI rules.

81. This paper has two objectives. First, to review the evolution of regulations affecting capital flows in Chile, their impact on specific flows, and to discuss methodological problems in measuring net inflows and short-term capital inflows. Second, to survey and critically assess the most recent empirical evidence on the effectiveness of the Chilean URR in achieving four policy objectives: to increase the effectiveness of monetary policy; to reduce total net capital inflows; to reduce both the rate of real exchange rate appreciation and its variance; and to alter the composition of net capital inflows against short-term net capital inflows. Sections B and $\mathrm{C}$ cover those two objectives. Section $\mathrm{D}$ concludes the paper indicating directions for future research and drawing policy implications. 


\section{B. Evolution of Capital Account Restrictions in Chile in the 1990s}

82. Chile's gradual approach to opening its capital account was influenced both by macroeconomic policy concerns in a small, open developing economy, and Chile's first unhappy experience with rapid opening of the capital account in the early $1980 \mathrm{~s}^{39}$ In early 1990 's the main concern of policymakers with the opening strategy was to (i) maintain monetary policy independence; (ii) prevent excessive appreciation of the real exchange rate; and (iii) moderate the buildup of speculative short-term liabilities. As fiscal policy in Chile was assumed to have a small overall impact on spending (Massad (1998)), monetary policy became the main tool for stabilization. Some controls on capital flows were judged to be needed to prevent interest rate arbitrage with capital mobility and limited exchange rate flexibility. Controls on short-term flows aimed at preventing potentially large adjustment costs on the real economy from real exchange rate volatility associated with sudden reversals of capital flows.

83. To achieve the above objectives Chile used three main instruments to regulate capital flows. ${ }^{40}$ These were a gradual liberalization of outflows, a one-year nonremunerated reserve requirement (URR) to be deposited at the central bank on inflows of certain short-term capital, and minimum ratings and maturity requirements for the issuance of bonds or equity abroad by Chilean residents. The rules are enforced by requiring that most inflow- and many outflow-related foreign exchange transactions take place in the formal foreign exchange market. ${ }^{41}$

84. This section discusses the evolution of the controls over the 1990 s and the behavior of the various components of capital flows. It also reviews a number of methodological issues related to assessing the impact of the controls on capital flows and their treatment in the literature on Chile. The main findings are: (I) the URR has been progressively tightened as a result of shifts of capital inflows to flows not subject to the URR; and (ii) there are serious methodological problems in measuring net inflows and short-term capital flows into Chile in

${ }^{39}$ Chile's first full liberalization of the capital account in 1979 was linked to the subsequent debt and currency crisis in 1982. This was largely the result of liberalizing capital flows when the domestic financial sector had not been reformed, unsustainable fixed exchange rate, and backward-looking indexation of wages (see e.g., Edwards and Cox, 1997).

${ }^{40}$ There is an ample literature describing Chilean capital account restrictions, see e.g., Eichengreen et al, (1998), Le Fort-Sanhueza (1997), Massad (1998), Quirk-Evans (1995) and Laurens-Cardoso (1998).

${ }^{41}$ The formal market consists of commercial banks and exchange houses and other entities licensed by the Central Bank. The remainder takes place in the informal market. In practice the exchange rate in both markets is virtually the same. See Annex Table 1 for a summary of current regulations on foreign exchange transactions. 
many of the reviewed studies, which may undermine some of their conclusions on the effect of the URR on capital flows and the term-structure of the flows.

\section{Restrictions on capital outflows}

85. Restrictions on capital outflows in Chile were gradually reduced over the decade (Table 1). Outward foreign direct investment (FDI) was liberalized at an early stage in 1991-92, which was accompanied by a gradual liberalization of bank lending abroad. Since 1992 institutional investors' ability to invest abroad has also been gradually liberalized. Finally, the minimum holding period of capital was reduced from three to one year in 1995, which in 1998 is the main remaining control on capital outflows. ${ }^{42}$ The rationale for maintaining the minimum-stay requirement is related to concerns about the volatility of capital flows. Some limits also exist on banks' and institutional investors' ability to invest in foreign securities, but these are justified mainly for prudential reasons.

86. Liberalization of capital outflows is likely to increase outflows but it could also increase inflows with an uncertain impact on net flows. Outflow liberalization has been suggested in the literature as one way of reducing the potentially adverse macroeconomic consequences of large inflows of capital (Quirk-Evans 1995, Schadler et al. 1993).

Liberalization of outflows should increase residents' holdings of foreign assets thus reducing net inflows of capital. This effect seems to be present in the Chilean case. Available data show that following the liberalization of outward FDI and portfolio investment, these outflows from Chile have increased over the decade, reaching nearly 3-5 percent of GDP in recent years (Figure 1). This figure and Figure 2 also show that total capital outflows from Chile have been important compared to the size of the inflows. However, outflow liberalization may also lead to larger inflows of capital. A number of authors including Williamson (1991) in general, and Labán and Larrain (1998) and Laurens and Cardoso (1998) in the case of Chile, have argued that liberalization of outflows by reducing perceived uncertainty of investing in the home country and by lowering domestic asset prices can also increase capital inflows. None of the papers reviewed offer recent empirical estimates of the effect of the liberalization of outflows on net inflows of capital in Chile. ${ }^{43}$

\footnotetext{
${ }^{42}$ This applies to foreign investment except Foreign Capital Investment Funds (FICEs) (5 years), and primary and secondary American Depository Receipts (ADRs).

${ }^{43}$ Labán-Larraín (1994) did investigate this and found a positive impact of outflow liberalization to net capital inflows, but the data used is quite dated as it ends in 1992.
} 


\section{Restrictions on inflows of capital}

87. Controls on inflows such as minimum risk classifications, maturity and amount for the issuance of securities abroad were gradually relaxed over the decade (see Table 1). In bonds, the minimum amounts were gradually eliminated, but a four-year minimum maturity and a certain minimum rating remain. For ADRs a minimum rating remains but minimum amounts have been eliminated. These rules aimed mainly at preventing adverse effects on country risk by potentially insolvent borrowers abroad. Most of these rules are more of a prudential nature.

88. The main instrument for restricting capital flows in Chile has been an unremunerated reserve requirement (URR) on capital inflows. The URR is an indirect, price-based measure in the form of a one-year compulsory deposit of a fraction of capital inflows at the central bank. It is expected to reduce capital inflows by increasing the cost of foreign short-term capital. The URR was to cover all foreign loans except trade credits, but its coverage has been extended over time to nondebt flows as well. It was set initially in 1991 at 20 percent and importers of capital could either make the deposit at the central bank or pay an upfront fee equivalent to the interest cost of the URR. Its implicit cost varies according to the maturity of the inflow. For example, the 30 percent URR has been estimated to increase the cost of borrowing by about 26 percent for one month maturities, or 2 to 3 percentage points for one year maturities (for more details see Cardoso-Laurens 1998 or Le Fort-Sanhueza 1998). ${ }^{44}$ Le Fort and Budnevich (1996) note that the expectations of an appreciating exchange rate and high returns to capital in Chile rapidly compensated the costs implicit in the URR especially on portfolio inflows - the financial cost of the URR of 1-3 percentage points per annum was easily offset by an expected appreciation the exchange rate. Both coverage and the rate have been subject to change over the decade (see Table 1) ${ }^{45}$ The URR was reduced to zero in 1998 in response to more adverse conditions in world financial markets in the aftermath of the Asian crisis.

89. The effectiveness of the URR has been subject of an intense debate in and outside Chile. Dooley (1996) and Quirk and Evans (1995) note that studies in general on the effectiveness of capital controls have suffered from the lack of widely accepted definition of

\footnotetext{
${ }^{44}$ This assumes a spread-inclusive international interest rate of 5 percent.

${ }^{45}$ In 1992 the rate was increased to 30 percent and coverage extended to foreign currency deposits. In 1995 the coverage was extended to secondary ADRs and in 1996 flows of potentially speculative nature also included FDI. The "speculative nature" of the inflows was to be judged by the Comite de Inversión Directa, which approves FDI incentive applications, and is defined as nonproductive investments. In 1995 the method of calculating the URR was changed so that it would need to be in dollars only (the low yen interest rates in 1993-1994 had substantially lowered the implicit costs of the URR for yen denominated loans). Estimates of the implied increase in the cost the URR as a result of this change range between 50-100 percent (Le Fort and Sanhueza (1997) and Valdés-Prieto and Soto (1997)).
} 
effectiveness. A number of studies have analyzed the effectiveness of the URR in reaching its macroeconomic objectives in Chile with the use of econometric analysis, which will be discussed in more detail in Part $\mathrm{C}$. This section instead examines effectiveness in a more informal way, by looking at how the various capital flows responded to the URR and how the restrictions evolved over time. The literature (summarized in Dooley 1996) in general points out that controls can be effective in the short-run while in the longer-run market participants find ways to evade the controls.

90. The coverage of the URR has been partial in Chile, which may have undermined its effectiveness by allowing substitution possibilities with uncovered flows. Important potentially volatile short-term flows such as trade credits and other nondebt creating capital flows were excluded from the scope of the URR. This was either for constitutional (strong support to export development in the Constitution led to exemption of trade credits from the URR) or practical reasons (difficulty of controlling informal flows as only formal market transactions are notified to the monetary authorities). Portfolio flows were initially exempt, but subsequently covered. Exempt longer-term flows are government credits, FDI and other capital creating flows such as primary issuance of ADRs (Le Fort-Sanhueza, 1997).

91. Controls on capital inflows were also frequently tightened in Chile over the 1990s. There were three major tightenings in the URR either in terms of extension in the coverage or increase in the rate during the decade. The first tightening took place in 1992 (rate increased from 20 to 30 percent). Data from the central bank show that initially in 1992 the URR covered about half of total gross inflows, but in the subsequent years its coverage declined to 24 percent (Figure 3) ${ }^{46}$ This may suggests that while the URR may initially have been effective, participants may have found ways to circumvent the restrictions over time. After further tightening in 1995 (extension to ADRs and change in base to U.S. dollars) and 1996 (exclusion of speculative investment from FDI) the share of URR covered flows in total gross inflows increased again to 30-40 percent. Similar estimates of coverage are given by Le Fort and Sanhueza (1997). While many other factors are likely to have influenced the various flows, the behavior of the individual components of capital inflows in Chile may suggest some pattern of a shift from covered into uncovered inflows in response to tightening of the URR. For example, Figure 4 seems to indicate that when the URR was extended to ADRs in 1995, another exempt inflow (FDI) started to grow faster. ${ }^{47}$ While some of the increase is likely to coincide with the start of large investment projects in the mining sector, Le Fort and Sanhueza (1997) and Labán and Larraín (1998) note that in 1995-1996 FDI became a major channel for

\footnotetext{
${ }^{46}$ Data on gross inflows of capital are difficult to estimate due to the inclusion of many flows (especially short-term) on a net basis in the balance-of-payments and are thus subject to some measurement error. This explains the negative numbers for "gross" inflows in certain years.

${ }^{47}$ Much of this can also be due to the Tequila crisis. Quarterly data might show better the exact timing of the changes in inflows in response to changes in regulations.
} 
portfolio inflows after the URR was extended to ADRs in $1995 .^{48}$ Once the rules on FDI were tightened in 1996 to exclude speculative capital, again another flow, trade credits by foreign suppliers and importers, started to increase gradually as markets may have found a new channel for exempt inflows (Le Fort and Sanhueza, 1997, and Soto, 1997). This may have led to migration of capital flows via the disintermediation of the taxed domestic banking system. This would be supported by the fact that since 1995, despite increased trade flows, trade credits by domestic banks declined each year lowering their share in total credits substantially.

92. Despite the URR, capital flows in Chile have been volatile during crisis periods. In response to the crisis in world financial markets large capital outflows especially of portfolio and other short-term capital took place in 1995 and in 1997-1998 amounting to about 5-6 percent of GDP in the latter year. Although the URR never intended to isolate Chile from events in world markets, one implicit aim of the URR was to reduce the volatility of capital flows. Few of the studies reviewed have measured the impact of the URR on this. Laurens and Cardoso (1998) offer some estimates of standard deviations of different components of net inflows. Their results show that standard deviation of short-term capital increased over time. One could argue that without the URR volatility could have been even higher than at present, or that because of partial coverage of the URR and migration of flows it has not been effective in meeting this policy goal. Whether the URR was effective in reducing volatility of capital flows in Chile may be a topic for further research.

\section{Methodological issues}

93. The estimates of the impact of the URR on net capital inflows may be biased if the analysis does not take into account the possible effect of other factors which may affect net inflows. In the case of Chile, these factors include in particular the liberalization of outflows and the government's debt pre-payment and debt conversion program in the $1990 \mathrm{~s}^{49}$ The effect of the liberalization of capital outflows was discussed above; none of the studies reviewed have controlled for this factor. Regarding the government's debt pre-payment and debt-conversion programs, Figure 1 shows that those programs resulted in large outflows,

\footnotetext{
${ }^{48}$ One indicator of this is a rapid increase in the share of investments into the financial sector in total FDI (Le Fort and Sanhueza 1997) suggesting that the URR exempt FDI flows contained a large amount of speculative capital inflows into the financial sector instead of capital actually invested in real assets of enterprises.

${ }^{49}$ There are naturally many other factors such as the conditions of supply of funds to Chile in international capital markets, perceived risk premiums of Chilean borrowers, which to a large extent are influenced by the country's macroeconomic policy environment. These and other factors are discussed more below.
} 
amounting to 2-3 percent of GDP especially in the years that the URR was tightened. ${ }^{50}$ Thus net inflows may have declined due to factors other than the URR after its tightening. Figure 2 suggests that the patterns of net inflows, and net inflows adjusted for the above two government programs are quite different. Laurens and Cardoso (1998) made an attempt to take account of this problem by using net (private) inflows of capital, which excludes the impact of the public debt payments on net inflows. Valdés-Prieto and Soto (1997) also include only short-term credits to the private sector in their estimation (Table 2).

94. Another important measurement problem is related to the definition of short-term capital flows, which in the Chilean case raises three issues: (i) the role of nondebt creating flows in short-term capital; (ii) inclusion of portfọlio flows in short-term capital; and (iii) differing definitions of short term debt in Chile.

95. First, given the partial coverage of the URR and the possibility of substitution between different liabilities, the results of any analysis excluding other short-term nondebt creating capital from total short-term flows are likely to be biased. As discussed above, inflows of nondebt creating short-term capital not covered by the URR can be important (Le Fort and Sanhueza 1997). ${ }^{51}$ This includes transactions reflected in errors and omissions and other nondebt creating short-term capital ("otro capital") categories of the balance-of-payments. Figure 5a shows that the amounts of these transactions can be important. However, many of the reviewed studies use either short-term debt or another partial measure of net short-term capital inflows to measure the effectiveness of the URR in reducing short-term capital inflows to Chile. Valdés-Prieto and Soto (1997) include errors and omissions but exclude "otro capital" in addition to short term private credit in their estimate of short-term capital, and finds some impact of the URR in reducing short-term capital flows. Le Fort and Budnevich (1996) also discuss the impact of the URR on short-term debt and find that it has declined as share of total debt. Eichengreen et al. (1998) discuss the impact of tightening of the controls in 1995 on short-term debt only, but conclude that the impact of the controls on the termstructure of debt is ambiguous. In the Chilean case the focus on short-term debt and exclusion of other short-term capital flows in the balance-of-payments in assessing the effectiveness of the URR may be particularly problematic as the aim of the government seems to have been a reduction in "speculative" short-term flows (Massad 1998) and not only debt flows. 52

\footnotetext{
${ }^{50}$ The 1995 numbers are also likely to be influenced by the Tequila crisis, which in Chile resulted especially in large outflows of portfolio capital (Labán and Larraín 1998).

${ }^{51}$ These categories in some papers are called informal market flows, see e.g. Le Fort and Sanhueza (1997).

${ }^{52}$ Speculative flows are there defined as "operations that focus on the short-term prospective of rates and asset prices, regardless of whether those rates are consistent with the fundamentals and are therefore unsustainable".
} 
96. Second, the exclusion of portfolio flows from short-term flows is likely to bias the results of the studies in reducing short-term flows as well. By extending the coverage of the URR to portfolio flows in 1995 the authorities implicitly seem to have considered that portfolio flows are to be included in the category of "undesirable" or speculative short-term flows, or that they contain capital inflows that are evading the URR. Furthermore, Figure 4 suggests that portfolio flows have been volatile and responded rapidly to changes in market sentiment. Given that one of the objectives of the URR was to reduce "speculative" capital flows, and that a large part of portfolio flows are likely to fall in the "speculative" category and be of short-term nature, these concerns would argue in favor of including portfolio flows in short-term flows and not in long-term FDI in Chile. Thus it is somewhat surprising that all of the reviewed studies have included portfolio flows in long-term capital. Edwards (1998) mentions the volatility of portfolio flows as an issue but goes no further in addressing the issue in his estimation. An illustrative calculation with a broader measure of the term structure of liabilities (estimated stocks of all short- and medium-term liabilities including portfolio and FDI) shows that the share of short-term liabilities in the total increased slightly until 1995 and only regained the pre-URR levels in recent years at about 20 percent of total (Figure $5 \mathrm{~b}$ ). ${ }^{53}$

97. In practice, the volatility or "speculative" nature of various especially investmentrelated capital flows can be hard to establish and is subject to some debate in the literature. Portfolio flows have been listed in many studies of emerging markets as part of "hot money" that can aggravate a crisis by rapidly leaving the country (e.g., Merryll Lynch Daily). The ratio of portfolio flows to reserves is at times also used as an indicator of a country's vulnerability to changes in financial conditions. On the other hand, Quirk and Evans (1995) cite evidence that even long-term capital flows are not necessarily more stable than flows through instruments with nominally short maturities (see also Claessens, Dooley, Warner 1995). Thus a distinction between FDI and portfolio flows in terms of volatility or likely duration of stay in a country can be arbitrary.

98. Certain authors note that as the macroeconomic impact of short-term debt flows and portfolio flows can differ the former may justify more concern by policy makers in terms of its burden on reserves in the short-run. This may justify the exclusion of portfolio flows from short-term or "speculative" capital. Eichengreen et al. (1998) note that short-term debt compared to portfolio flows has some particularly disruptive features, and may thus deserve special concern by policymakers. These authors note that the macroeconomic consequences of reversals especially of short-term sovereign and banking debt can be devastating as outflows from sovereign debt markets disrupt the international financial relations of the country. In contrast, outflows of equity capital have their most immediate impact in asset prices with more indirect effects on bank balance sheets, or the budget.

${ }^{53}$ The stocks of FDI and portfolio are presented at historical values and are subject to wellknown measurement problems. 
99. Third, official statistics on short-term debt exclude trade credits, which may affect the results of studies on the effectiveness of the URR. Given that these credits have increased especially in recent years, when other short-term debt has declined, any analysis based on the evolution of the official stock of Chile's short-term debt with official data is likely to overestimate the decline in short-term liabilities (Eichengreen et al. 1998, and to some extent Eyzaguirre and Schmidt-Hebbel 1998). The inclusion of trade credits in 1997, for example, increases the stock of short-term debt from US\$1.2 billion to US\$5.2 billion. The analysis is further complicated as estimates of the amount of short-term debt vary between official sources and the BIS. ${ }^{54}$ For example, for end-1997 the BIS estimate of short-term debt to banks is about US $\$ 10$ billion.

100. Given the above the generally held view that most studies of the Chilean URR on the structure of inflows show some impact in favor of longer-term capital inflows (Massad 1998) may need further research/more debate. The various measurement problems of short-term capital flows discussed above cast some doubt on these conclusions. The problems of properly measuring short-term flows and debt in Chile and the substitution between different flows suggest that most studies of the URR have underestimated the amount of short-term flows.

\section{A Survey of the Literature on the URR in Chile}

101. The literature on capital controls is vast. There is a large number of surveys on the theoretical arguments for and against capital controls so that they will not be repeated here. ${ }^{55}$ Instead, this section relates the specific objectives of the Chilean program of controls on capital inflows to the evidence on their performance. It is asked whether or not those controls had a measurable effect on the economic variables that the program intended to affect.

102. Following Soto (1997) closely, we evaluate the URR in four dimensions that correlate well with the objectives of the measure: (i) its effect on the short-term real interest rate differential between Chile and its trading partners (or on the domestic real interest rate); (ii) its effect on total net capital inflows; (iii) its effect on the path of the real exchange rate; ${ }^{56}$ and (iv) its effect on the ratio of short- to medium- and long-term capital flows. The summary of the reviewed studies is presented in Tables 2 and 3 . Table 2 contains the main results that the

\footnotetext{
${ }^{54}$ The differences between official and BIS statistics are currently under investigation by the authorities.
}

${ }^{55}$ Obstfeld (1995) has a review of the literature. The book by Haq et al. (1996) and its review by Nadal-De Simone (1997) summarize the microeconomic and macroeconomic issues involved. Short surveys of the Chilean evidence are in Soto (1997) and Massad (1998).

\footnotetext{
${ }^{56}$ An upward movement in the exchange rate implies a real appreciation of the domestic currency.
} 
reviewed papers consider to be robust, and Table 3 is a critical review of the specification and estimation problems affecting the results of Table 2 .

103. The studies reviewed conclude that: there is some evidence that the URR has been successful in increasing domestic interest rates; there is a relatively weaker evidence that the URR has reduced the magnitude of capital inflows into Chile and altered the composition of capital inflows in favor of medium- and long-term capital inflows; and actually no evidence that the URR affected the level of the real exchange rate. The studies reviewed, however, contain both important methodological problems in measuring net capital inflows and shortterm capital inflows into Chile as well as econometric problems in assessing the effectiveness of the URR. These problems may have biased the estimates either in favor or against the hypothesis that controls were effective. So, on this basis, it is difficult to assess the effectiveness of controls in Chile. Also as no study assesses empirically the eventual welfare benefits and costs of the URR, it is not possible to judge the effect of the URR on welfare.

\section{Selective quantitative results on the effectiveness of the URR in Chile}

\section{Evidence on the effect of the URR on the real interest rate differential/interest rate}

104. Using statistics of the balance of payments components and of major macroeconomic variables, Le Fort and Budnevich (1996) argue that given the sound economic policies followed during the 1990s in Chile, the URR has allowed to keep the real interest rate differential in favor of Chile, as desired by the authorities. However, they do not provide any econometric test of the effectiveness of the tax. As argued by Valdés-Prieto and Soto (1997), in the case of a fixed or predetermined exchange rate regime, when a tax on capital inflows generates revenue, it is relevant because it is not avoided fully. In that case, however, the interest rate differential between the taxed sector and foreign interest rates by itself is uninformative regarding the effectiveness of the URR. Econometric work is needed to estimate the degree of effectiveness of the capital control, i.e., the effect of the URR on the sum of changes in the net demand for credit of the exempt group and the net demand for credit of the taxed group, as well as the effect of the URR on the real interest rate differential.

105. Herrera and Valdés-Prieto (1997) use monthly data from January 1994 to August 1996 to estimate the maximum interest rate differential that the URR has generated in Chile. Their work stands out from the rest because it does not calculate the effects of the URR on Chilean interest rates under the assumption that the duration of the foreign investment in Chile is fixed a priori-what the authors refer to as the myopic version of the model. ${ }^{57}$ Instead,

${ }^{57}$ The implicit myopic tax rate is calculated as follows:

$$
T A X=\frac{(i *+s) \text { URR Rate }}{(1-\text { URR Rate })} \quad \frac{\text { Holding Period }}{\text { Loan Maturity }}
$$


entry and exit decisions in the Chilean market are viewed as the result of an optimization process in which the duration of the investment is a function of the state of the economy and the stochastic process followed by the domestic and foreign interest rates ${ }^{58}$ and the URR itself. As a result, the cost of investing in Chile (the cost of maintaining a licence to invest in Chile), is compared with the expected future interest rate differential which in turn is affected by future entry and exit decisions.

106. The main result is that the URR generates an interest rate differential which is significantly more modest than the usually calculated under the myopic alternative. As a way of comparison, the maximum interest rate differential a 30 percent URR can generate is 2.3 percent in three-month investments and 1.25 percent in one-year investments relative to 10.5 percent and 2.5 percent respectively under the myopic alternative. When the authors add other costs of investing in Chile such as the tax treatment or the stamp tax, the differential in three-month investments increases to 3 percent and to 1.7 percent in one year investments.

107. Soto (1997) uses monthly data from January 1991 to June 1996 to estimate a 5 -variable VAR in the rate of change ${ }^{59}$ of the US $\$$ LIBOR rate, the domestic interest rate, total capital flows, the real exchange rate and the implicit tax. The author imposes two contemporaneous restrictions on the VAR: first, the foreign interest rate is exogenous and second, the monetary authority changes the URR tax only in response to past fluctuations in total capital flows and in the real exchange rate. Therefore, only shocks to LIBOR and to the

${ }^{57}$ (...continued)

where $I^{*}$ is the foreign real interest rate and $s$ is a measure of the risk premium. This simply implies that the cost of the URR is the tax cost divided over the fixed maturity of the investment.

${ }^{58}$ The authors perform their analysis in continuous time and make different assumptions about the statistical properties followed by the interest rate processes. They start with a simple Brownian motion (the equivalent of a random walk process in discrete time), then they assume an Ornstein-Uhlenbeck process (the equivalent of an AR (1) process in discrete time), and finally, they combine the Ornstein-Uhlenbeck process with a regime change that follows a Markov 1 process.

${ }^{59}$ Soto does not explicitly say whether his VAR is in levels or in first differences. However, it is assumed here that as most variables used (or at least the LIBOR rate) are integrated processes of order one, hereafter I (1) processes, the VAR is in first differences. I (1) variables contain a unit root and are therefore nonstationary. In contrast, an I ( 0 ) process is stationary. 
URR are identified. Given the objective of this review, only shocks to the URR are considered. ${ }^{60}$

108. The URR tax has a statistically significant effect on the domestic interest rate in the medium term (about a year) but this effect is transitory and of small size. For example, a URR of 30 percent increases the domestic interest rate by 30 b.p. after a year. This results are confirmed by another VAR that comprises the LIBOR rate, the domestic real interest rate, the tax and the nominal interest rate.

109. Edwards (1998a and 1998b) performs a number of tests of the proposition that controls on capital inflows have had an statistically significant effect on the real interest rate in Chile. Firstly, he uses an AR(1) model with monthly data and an $\operatorname{ARMA}(2,1)$ model with quarterly data on interest rate differentials in order to calculate the expected rate of devaluation. ${ }^{61}$ The interest rate differential adjusted for this "expected" exchange rate change is used as a proxy for the equilibrium real interest rate differential.

110. An unrestricted VAR is estimated with quarterly data for a period without capital controls (1981/I-1992/II) and for a period with capital controls (1992/III-1996/IV). The variables included are the cyclical components of the following HP-filtered ${ }^{62}$ series: a bilateral real exchange rate relative to the United States, quarterly changes in international reserves as a proxy of capital flows, domestic credit growth, the rate of inflation, the real interest rate differential, adjusted by a proxy for expected devaluation as described above, and a measure of the importance of capital controls.

111. The impulse response functions of the VAR show that deviations of real interest rate differentials form their equilibrium values tend to last longer in the period with capital controls, i.e., they last more than four quarters in the period with controls while they last two quarters in the period without controls.

112. Secondly, using monthly data on real interest rate differentials, Edwards estimates a number of alternative ARMA processes for four different time periods. For the periods

\footnotetext{
${ }^{60}$ As stated above, results that Soto considers not to be robust on the basis of the impulseresponse functions, are excluded. For example, results that are sensitive to the number of lags used in the estimation such as the effect of the URR on the real exchange rate are excluded from the discussion.

${ }^{61}$ There is no offshore forward market in Chilean pesos and the domestic forward market started only in 1994.

${ }^{62}$ The value for smoothing the growth component of the series used by Edwards, what Hodrick-Prescott refers to as $\lambda$, is not reported. Note that a value of $\lambda$ that is "too large" smooths the stochastic trend of the series "too much", and as a result the volatility of the cyclical component is "too little." This may explain some of Edwards' results.
} 
1988:1-1991/6 as opposed to 1991/7-1996/12, the real interest rate differential did not seem to follow a different statistical process. This is true either when allowance is made for changing country-risk or not. However, changing the starting date of the estimation period from 1991 to 1992 or to 1993 when the URR was strengthened-did have an effect. It seems that the persistence of interest rate differentials indeed increase after those dates supporting the idea that the restrictions gave the monetary authorities greater control over interest rates.

113. Thirdly, Edwards used a rolling regression technique to estimate the degree of persistence of interest rate differentials during the period with capital controls. The results suggest again that the degree of persistence of real interest rate differentials increased slightly although rolling estimates of the steady state differentials declined gently after 1995. The latter may indicate that Chile's ability to control interest rate differentials over the longer run may not have been that much.

\section{Evidence on the effect of the URR on total capital flows}

114. Le Fort and Sanhueza (1997) argue that the URR has been effective in the sense that at least for some time after a change in the regulation was made, total capital inflows fell and there was no clear upward trend in total capital inflows during their sample period (1990-1996). They do not provide econometric test of their hypothesis.

115. Eyzaguirre and Schmidt-Hebbel (1997) estimate the effect of the URR tax on capital flows using as dependent variable net changes in foreign assets of the central bank deflated by the US CPI. The regressors are the terms of trade, the real exchange rate, the ratio between net financial wealth to GDP, the domestic real interest rate and net foreign interest receipts. ${ }^{63}$ Only the effect of the real interest rate on the net changes in foreign assets held by the central bank is reported.

116. If the URR tax affects the domestic interest rate positively, it will affect capital flows as well. However, the only statistically significant variable, i.e., the interest payed on net foreign assets has the wrong sign. None of the other regressors, in particular the interest rate or the real exchange rate, has an effect that is statistically different from zero. When the lagged dependent variable is included among the regressors, all regressors become statistically insignificant. The authors conclude that there is some weak evidence that the increase in the domestic real interest rate has contributed to increase the stock of net foreign assets in Chile (improved the current account).

117. Soto (1997) uses the 5-variable VAR described previously to estimate the effect of the URR on total capital flows in Chile. He finds that the impact effect is positive, i.e., the URR

${ }^{63}$ The authors report that the dependent variable is an I (0) variable, i.e., a stationary variable, while the regressors are all I (1) variables, i.e, they contain a unit root and are therefore nonstationary. This makes the interpretation of the regression extremely difficult. 
increases capital inflows on impact, but it reverses itself after two months. After six months, the effect becomes statistically insignificant. The magnitude of the effect is always small, i.e., the introduction of a 30 percent tax reduces net capital inflows by approximately US $\$ 400$ million in total.

118. Laurens and Cardoso (1998) try to assess empirically the effectiveness of the URR on net capital inflows as well as on their composition using an index that measures the restrictiveness of the capital controls in Chile. The index is constructed by multiplying the tax base (estimated by a series of flows taken from the BOP and added from 1985 onwards) by the tax rate and using quarterly data from $1985 / \mathrm{I}$ to $1994 / \mathrm{IV} .{ }^{64}$ Net private inflows are regressed on the real interest rate differential between Chile and the rest of the world, Chilean GDP in U.S. dollars, the index measuring restrictiveness (using linear, quadratic and cubic functional forms) and some quarterly dummies. ${ }^{65}$

119. The authors find that the introduction of the URR and the broadening of its base over time had a negative effect on the level of capital inflows independently of the functional form. However the functional form does matter for the duration of the effect of the URR index on the change in net private capital inflows. A linear form provides a statistical significant effect on the slope of the control index only at the 10 percent confidence level. Thus, the authors argue that the effect of capital controls on net private capital inflows seems quite persistent (a zero slope coefficient implies a permanent effect in Laurens and Cardoso's model). When a cubic form is used instead, the slope is statistically different from zero, and thus the tax seems to affect net private capital inflows only temporarily. After two quarters of the introduction of the URR, the index seems to indicate that capital controls were ineffective.

\section{Evidence on the effect of the URR on the path of the real exchange rate}

120. Le Fort and Budnevich (1996) and Le Fort and Sanhueza (1997) argue that the URR allowed Chile to keep an interest differential in favor of the domestic economy without generating an increase in the expectations of a currency depreciation to fulfil the interest rate arbitrage condition. The URR was successful in preventing a currency appreciation followed by a depreciating trend. They do not provide an econometric test of their hypothesis.

${ }^{64}$ Actually, Laurens and Cardoso calculated two versions of the index that differ only in that Index I assumes that all of the effect of the introduction of the URR was responsible for the fall in net capital inflows in 1991/II while Index II assumes that all of the effects were felt from 1991/III onwards.

${ }^{65}$ Importantly, our tests indicate that net capital inflows are $\mathrm{I}(0)$, the real interest rate differential between Chile and the rest of the world (i.e., US, Germany and Japan) is likely to be $\mathrm{I}(0)$, and domestic GDP is $\mathrm{I}(1)$. This makes the interpretation of the regression difficult. 
121. Soto (1997) find that increases in the URR do not affect the path of the equilibrium real exchange rate because the URR is not cointegrated with the real exchange rate. Similarly, the tax does not seem to depreciate the real exchange rate in the short run.

122. Edwards (1998a and 1998b) re-estimated his VAR described before for a period without capital controls (1981/I-1991/II) and for a period with capital controls (1991/III-1996/IV) and evaluated the real exchange rate response to capital flows innovations. Similarly, he used the longer period VAR (1987-1996) estimates to evaluate the impulse response to a shock to the tax equivalence of the URR. Two results are noteworthy: first, the effects of a capital inflow innovation on the real exchange rate are similar across periods suggesting that the impact of the URR on the behavior of the real exchange rate has not been statistically significant and second, the variance decomposition of the forecast errors of the real exchange rate confirms that the URR has not been effective in affecting the real exchange rate behavior. The capital account restriction variable explain no more than 3 percent of the forecast error variance.

123. Soto (1997) studies the effect of the URR on the volatility of the real exchange rate using a bivariate VAR with the tax rate and an estimated measure of the standard deviation of the real exchange rate. Although the URR does not seem to explain more than 6.5 percent of the variance in the real exchange rate volatility, the impulse-response function shows that a standard deviation shock in the tax contributes to the reduction of the volatility of the real exchange rate after the second month by 10 percent, and that effect declines to 4 percent in the medium and long run. A 30 percent tax can reduce the volatility of the real exchange rate by about 20 percent.

\section{Evidence on the effect of the URR on the composition of capital flows}

124. Le Fort and Budnevich (1996) and Le Fort and Sanhueza (1997) argue that the change in the composition of capital flows in favor of relatively more FDI and more medium- and long-term debt is one of the outcomes of the URR. As the Chilean macroeconomic policy framework was sound during the same period and the country continued to buy back foreign debt and liberalize capital outflows, it is difficult to assess the hypothesis of the effectiveness of the URR without formal econometric work. ${ }^{66}$

\footnotetext{
${ }^{66} \mathrm{~J}$ ohnston and Ryan (1994) use a sample of industrial countries to show that FDI flows are very responsive to the liberalization of capital flows. Labán and Larrain (1997) show that liberalizing capital outflows increases net capital inflows because it reduces the irreversibility of investments. The same conclusion is obtained in the Herrera and Valdés-Prieto's (1997) paper where a reduction in exit costs reduces the feasible maximum interest rate differential or alternatively, reduces the minimum rate demanded for entering the country.
} 
125. Eyzaguirre and Schmidt-Hebbel (1997) estimate the ratio of short- to medium- and long-term stock of liabilities as a function of the domestic real interest rate and the tax ${ }^{67}$ The best representation of the equation excludes the interest rate and includes a lagged dependent variable together with a summation of the lags 10 to 13 of the tax. The summation is significant and the authors conclude that the tax is effective in affecting the composition of capital flows to Chile but its effect is felt only after about a year.

126. Valdés-Prieto and Soto (1997) use quarterly data for the period 1987/IV to 1996/IV to estimate the effect of the implicit tax on the ratio to GDP of total short-term foreign credits to the private sector plus errors and omissions of the balance of payments. Additional regressors are the domestic real interest rate used by the monetary authority to set policy, the US\$ LIBOR rate minus WPI inflation, a proxy for expected real exchange rate devaluation, ${ }^{68}$ a dummy variable for the country rating according to Standard and Poor's, a proxy for market access of emerging markets, a ratio of imports to GDP, a ratio of exports to GDP and net foreign exchange purchases of the central bank. ${ }^{69}$

127. Valdés-Prieto and Soto find that in the period 1987/IV-1994/IV, the URR was ineffective in altering the composition of capital inflows. However, when they extend the sample to 1996/IV and thus include the nearly doubling of the tax rate of the URR in early 1995 , the coefficient of the higher tax is significantly different from zero and negative as expected. The authors warn that their results may be biased because they do not take into account the effect of tax avoidance that substitutes taxed short term flows for exempt flows not classified as short-term credit (e.g., the URR was not applied to the hedging of secondary ADR operations). The authors conclude that although the much higher tax rate of the URR in 1995 seemed to affect the composition of the short term flows they measure, the fact that

${ }^{67}$ The authors report that all the variables are I (1). Because the estimator used is two-stage least squares, and the variables are in levels, a test for the nonstationarity of the residuals would be important to determine whether the regression results are spurious or not. However, no test on the nonstationarity of residuals is reported.

${ }^{68}$ The proxy includes 3 steps: first, a model for the level of the real exchange rate is estimated using a time trend, the share of government expenditure in GDP, the terms of trade, and the risk rating of the country. Second, a model for the rate of change of the real exchange rate is estimated based on the lagged change in the nominal exchange rate, the nominal interest rate, the URR, the foreign currency purchases of the central bank, and two lagged residuals of the first equation. The first two steps form a sort of error-correction model in order to account for the unit root in the real exchange rate. Third, the devaluation predicted in the second step is smoothed using a weighted average of the current and past values with optimal weights.

${ }^{69}$ The authors mention (no test is reported) that all variables are I (0). 
other categories of short-term inflows increased makes it unclear what the effect of the URR on the composition of capital inflows was. ${ }^{70}$

128. Soto (1997) estimates a VAR comprising a LIBOR rate, the domestic interest rate, the tax rate and a measure of short-term capital flows to assess the impact of the URR on shortterm capital flows. ${ }^{71}$ The effect of the tax on short capital flows is significant but of small magnitude. Soto also uses a bivariate VAR of the tax rate and the ratio of net short-term debt to net medium- and long-term debt and finds that the URR affects the composition of capital flows significantly after 15 to 20 months and the magnitude of that effect is important.

129. Laurens and Cardoso (1998) use their index of restrictiveness and the same regressors described in section 3.2 to test whether the URR affected the composition of capital inflows in Chile. The dependent variables used are short-term capital flows and medium- and long-term capital flows. They find that the URR tax had a negative effect on short-term flows. However, the effect is short lived as it lasts for less than a year. They also find that the tax has no impact effect on medium- and long-term capital flows but a negative effect develops over time, i.e., an effect contrary to what the authors' model predicted, and that effect seems to increase with time. The authors think this anomaly may be due to the fact that their measure of capital flows did not include FDI and portfolio investment.

\section{Assessment of selective quantitative studies on Chile's URR}

130. Table 3 contains a summary of the major econometric features of the studies reviewed in this selective survey. As mentioned above, the main general conclusion that can be drawn from Table 3 is that available empirical studies contain enough econometric problems to cast doubts on their conclusions about the effectiveness of controls on capital inflows in Chile. The possible exception could be the positive effect of the URR on domestic interest rates. However, specification issues such as the lack of control for the relaxation of regulations affecting capital outflows during the 1990s, for the effect of sterilization operations by monetary authorities on domestic real interest rates, for foreigners' willingness to lend, or the possible effects of tax incentives on inward FDI flows, may have biased the estimates both ways.

131. Besides the simultaneity bias ${ }^{72}$ affecting some studies on the effectiveness of capital controls in Chile (Eichengreen et al. 1998), there are a number of other econometric problems: (i) studies do not normally test for the nonstationarity of the variables used in the

\footnotetext{
${ }^{70}$ Valdés-Prieto and Soto (1997) also find that the elasticity of capital flows to changes in the interest rate used by the monetary authorities is not affected by the URR.

${ }^{71}$ The VAR has the same restrictions described in paragraph 33.

${ }^{72}$ Simultaneity bias and the possibility of cointegration among the variables are formally illustrated in Appendix 1.
} 
regressions; (ii) with two exceptions, there is no test of the possibility of common trends in nonstationary variables, or cointegration; (iii) serial correlation (possibly of different orders) in the residuals is pervasive; and (iv) misspecification problems (i.e., use of irrelevant variables, the omission of relevant variables or the presence of nonlinearities) are clear in some cases, and should have been tested in others.

132. With the help of Table 3, let us briefly summarize the assessment of the studies from the perspective of the four dimensions of the problem.

\section{The positive effect of the URR on domestic interest rates}

133. This effect is the most robustly estimated of all four considered in this survey. Herrera and Valdés-Prieto (1997), Soto (1997) and Edwards (1998b) find that this effect is small and does not last for more than a year. Herrera and Valdés (1997) convincingly show why the effect is likely to be smaller than usually suggested in the literature implying that the increase in the autonomy of monetary policy may not be as much as indicated by other studies. This conclusion has to be qualified, however, because none of the reviewed studies (with the possible exception of Eyzaguirre and Schmidt-Hebbel, 1997) controls for the impact of the sterilization operations of the monetary authorities in Chile during the 1990s. A regularity discussed in Calvo et al (1993) is that the reduction in interest rates in Latin America has been much slower in countries that have sterilized than in those that have not. ${ }^{73}$ Labán and Larrain (1997) argue this for Chile as well. Therefore, part of the positive effect that studies have found that the URR had on Chilean interest rates during the 1990s may be due to the sterilization operations of the central bank. This clearly is a topic for further research. The implication is that the reviewed studies may be subject to a misspecification bias.

\section{The negative effect of the URR on total net capital flows}

134. The negative effect of the URR on total net capital flows reported by Soto (1997) and Laurens and Cardoso (1998) is small and lasts for two quarters. Soto, however, does not assess the robustness of his estimates by reversing the ordering of the variables in the VAR. It is well-known that the ordering of the variables in a VAR affects the impulse response functions and the variance decomposition results in a significant way if the correlation between the variables is "large." Given that a rule of thumb in practical work is that correlation is large when it is over 20 percent and that the correlation between the real LIBOR rate and the tax rate in Soto's sample was 62 percent, testing the robustness of results for changes in the ordering of the variables seems relevant.

\footnotetext{
${ }^{73}$ Eyzaguirre and Schmidt-Hebbel (1997) use the first lag of the PRBC rate-short-term real paper rate-until May 1995, and the interbank rate thereafter, to proxy the main instrument of monetary policy. Note that the first lag of that variable captures (probably among other things) the effect of monetary policy sterilization operations on interest rates. The variable is statistically significant in explaining the covered interest rate differential.
} 
135. An additional problem also mentioned by Soto is the possibility of misspecification. However, no test for block exogeneity and Granger causality to detect whether to incorporate or not a variable into the VAR is reported.

136. Finally, the short-term nature of the effects of the URR on total capital flows may result from not allowing in the VAR for the possibility of a long-lasting relation between the URR - which the authorities clearly said they viewed as a permanent measure-and capital flows. No test of cointegration is reported. To illustrate this point, Figure 6 shows the cyclical part of the ratio to GDP of the capital account. It seems that the introduction of the URR, although presented as a permanent measure, did not affect the upward trend of total net capital flows in Chile during the sample period. ${ }^{74}$

137. Laurens and Cardoso (1998) do not control for the possibility of simultaneity bias in their regressions despite that it is likely that changes in the URR tax may occur as a response to capital inflows. This may have biased their results against effectiveness of the URR. Moreover, it is difficult to tell what the alternative hypothesis is in Laurens and Cardoso (1998). A statistically significant negative intercept suggests that the URR had a negative effect on the level of capital flows. A slope coefficient statistically equal to zero suggests that the control has had a permanent effect on total capital flows. If the slope coefficient is instead positive, the control can have an effect on capital flows that is positive or negative depending on the magnitude of the slope relative to the magnitude of the intercept.

138. None of the studies reviewed in this survey controls for the effect of the liberalization of capital outflows in Chile which has been suggested as one of the causes responsible for the increase in net capital inflows (Labán and Larraín, 1997, and Laurens and Cardoso, 1998). This may have biased results against the effectiveness of the URR. Therefore, it seems necessary to control adequately for the removal of controls on capital outflows in order to disentangle the effect of the URR from the effect of the liberalization of capital outflows on total capital flows in the 1990s. Figure 7 shows that both the trend in capital inflows and the trend in capital outflows increased by nearly 7 percent of GDP between 1990 and 1998 . Moreover, the cyclical behavior of both types of capital flows is sufficiently different to justify taking them into account separately when analyzing the impact of the URR on capital flows in Chile. The drop of nearly 7 percent of GDP in the cyclical part of total capital flows in 1995

\footnotetext{
${ }^{74}$ The smoothing of the series uses a version of the Hodrick-Prescott filter--which allows for a stochastic trend--with a degree of smoothing driven entirely by the data and using a crossvalidation criterion (see Ullah and Vinod, 1993, for a description of the automatic method of cross-validation). The program was kindly provided by John McDermott.
} 
(see Figure 6), can be decomposed into a 5 percent of GDP increase in capital outflows and a 2 percent of GDP fall in capital inflows (see Figure 7). ${ }^{75}$

139. Finally, no study controls for the increased availability of funds in the 1990s as opposed to the 1980s due to financial innovation, further economic integration, and the effect of successful Chilean reforms on foreigners' willingness to lend. ${ }^{76}$ This may have biased results against effectiveness of the URR. Similarly, the external environment such as the massive reshuffling of portfolios as a result of the Mexican crisis of 1994/95, should be part and parcel of a comprehensive analysis of the impact of the URR. This may have biased results in favor of the effectiveness of the URR.

\section{The negative effect of the URR on the real exchange rate}

140. In general, studies have not found a negative effect of the URR on the level of the real exchange rate in Chile. ${ }^{77}$ Eyzaguirre and Schmidt-Hebbel (1997) conclude that the indirect effect of the URR on the real exchange rate via affecting first the domestic real interest rate are not robust to changes in specification or in estimation techniques. Similarly, Soto (1997) indicates that his results of the effect of the URR on the level of the real exchange rate are not robust to the number of lags used in the VAR indicating thereby the possibility that the use of ordinary least squares may not be appropriate to generate consistent and efficient estimates. A SUR (seemingly unrelated equation) technique may be necessary instead.

141. Soto (1997) reports a significant negative impact of the URR on the volatility of the real exchange rate. However, given the high correlation between the URR and the foreign real interest, it is difficult to separate the effect of changes in the foreign real interest rate and their impact on the volatility of the real exchange rate from the pure tax effect. As changes in the ordering of the variables shocked are not reported, it is difficult to assess the robustness of the results. It would be interesting to test for the non-inclusion of the foreign real interest rate.

142. As Edwards' (1998b) results are from an unrestricted VAR, therefore, it is not possible to obtain a reliable picture on the interaction between the variables. This is especially important because the objective is to test whether the introduction of the URR tax affected the structure of the economy.

\footnotetext{
${ }^{75}$ It would be useful to take into account the impact of the "tequila" effect in total capital flows in 1995.

${ }^{76}$ As stated above, Valdés-Prieto and Soto (1997) use the country's rating according to Standard and Poor's to proxy Chilean market access and Edwards (1998) uses a country risk proxy in his regressions. This is, however, just one of the aspects determining the overall availability of funds.

${ }^{77}$ This result also applies to other studies not reviewed here but reported in Table 4.1 of Eyzaguirre and Schmidt-Hebbel (1997).
} 
143. Figure 8 a shows that the cyclical components of the weighted ${ }^{78}$ real interest rate differential between Chile and the U.S., Germany and Japan, and changes in the real effective exchange rate (lagged one year) seem to follow real interest rate parity quite closely. It actually seems that it takes about one year for changes in the real effective exchange rate to arbitrage any interest rate differential. Visual inspection of Figure 8a may suggest that the URR did not have a strong and lasting effect on real interest rate parity in Chile during the $1990 \mathrm{~s} .{ }^{79}$ As argued above, depending on the final effect of the liberalization of capital outflows on total capital flows, the effect of the URR tax on the real exchange rate may have been offset. However, this has still to be tested econometrically.

144. Figure 8b suggests one possible hypothesis that may help explain the causes of the steady appreciation of the peso since the last part of the 1980 s up until recently which may be fruitful to investigate further. If the microeconomic and macroeconomic reforms in Chile produced an increase in total factor productivity relative to the rest of the world, it is to be expected that, at least for some time, the real exchange rate of Chile will display an appreciating trend. We proxy the productivity differential between Chile and U.S., Germany and Japan by weighted differential in potential output growth. The data seem to confirm the Harrod-Balassa-Samuelson effect which predicts a tendency for countries with higher productivity in tradables compared with nontradables to have higher relative price levels, and thus, to have an appreciation of their equilibrium real exchange rates. Capital inflows into economies that have produced sound reforms may be also partly a response to the increase in productivity that the reforms sought. It seems thus important to disentangle the effects on the real exchange rate in Chile stemming from the increase in relative productivity from those deriving from capital inflows and the URR.

\section{The negative effect of the URR on the share of short term flows in total capital flows}

145. Eyzaguirre and Schmidt-Hebbel (1997) and Soto (1997) tests of the effect of the URR on the composition of capital flows use a ratio of short- to medium- and long-term capital flows. There are methodological problems in both studies. Eyzaguirre and Schmidt-Hebbel use a two-stage least squares estimator to account for the possible endogeneity of right-hand side variables. However, because their unit-root tests cannot reject the null of nonstationarity for all the right-hand side variables, and because there is serial correlation in the residuals, the

\footnotetext{
${ }^{78}$ The weights used for the real interest rate differential are the same as those used for the real effective exchange rate.

${ }^{79}$ Nadal-De Simone and Razzak (1998) expand the work of Baxter (1994) and show that real interest rate parity holds between the United States and Germany and the United States and the United Kingdom during the period 1980 and 1997 at the business cycle frequency band. Figure $8 \mathrm{a}$ for Chile and its major trading partners provides a very similar picture indeed.
} 
parameter estimates are biased. ${ }^{80}$ On the other hand, if the residuals contained a unit root, the regression would be spurious.

146. Issues of misspecification, ordering and estimation techniques affecting Soto's (1997) estimates were discussed in the previous sections and are, thus, not repeated here.

147. A more fundamental difficulty with studies that test the negative effect of the URR on the ratio of short- to medium- and long-term capital flows is the unclear definition of the null hypothesis. The ratio of short- to medium- and long-term capital flows may fall due to a whole range of different reasons. For instance, the ratio of short- to medium- and long-term capital flows may fall because short-term flows decline due to the introduction of the URR, while medium- and long-term flows remain unaffected. Alternatively, despite that the URR may be ineffective in reducing short-term capital flows, that ratio may fall because mediumand long-term flows increase due to, say, the tax incentives on FDI inflows put in place by the authorities. That ratio may also fall because developments in the term structure of interest rates in Chile entirely unrelated to the URR create incentives for a reallocation of investors' portfolios away from short-term capital. Studies using the ratio of short- to medium- and long-term capital flows should control for factors possibly affecting not only the numerator but also the denominator of that ratio. Otherwise it is unclear what is being tested.

148. Valdés-Prieto and Soto (1997) use instead a measure of short-term capital flows and Laurens and Cardoso (1998) use both short-term capital flows and long-term capital flows to test the effectiveness of the URR in affecting the composition of capital flows. Valdés-Prieto and Soto's (1997) use instrumental variables to account for the possible endogeneity of some of their right-hand side variables. The authors mention that all variables in their regressions are stationary although no tests for nonstationarity are reported. It is likely, however, that further tests for nonstationarity are necessary at least for the URR variable. Eyzaguirre and SchmidtHebbel (1997) as well as Edwards (1998) report their measure of the URR variable as nonstationary.

149. Valdés-Prieto and Soto's regressions are also affected by serial correlation in the residuals. This becomes obvious once the reported DW statistics is adjusted to take into account that the lagged dependent variable is included among the regressors. Therefore, the parameter estimates are biased.

150. Laurens and Cardoso's (1998) results are difficult to assess because the issue of nonstationarity is not addressed nor any test for serial correlation in the residuals is reported. Moreover, as suggested by Johnston and Ryan (1994), as programs of capital controls respond to capital flows, it is not rare to find that new controls over capital inflows are associated with increased capital inflows. Because the authority responds to increases in short-

\footnotetext{
${ }^{80}$ This becomes clear after the DW test reported is corrected because the lagged dependent
} variable is included among the regressors (i.e., the Durbin $h$ statistics). 
term capital flows by increasing the tax of the URR, it is possible that the equation is subject to simultaneity bias, a bias against effectiveness of the URR.

151. A large range of policy changes as well as nonpolicy changes (e.g., terms of trade shocks) may affect the capital account and, in turn, capital account developments may generate policy changes. This makes the estimation of the impact of controls on capital inflows difficult. Figures $9 a-c$ show the behavior of the short-term capital flow ratios to GDP for Chile, Brazil and Mexico, three countries that adopted quite different policy approaches to the capital account in the $1990 \mathrm{~s}^{81}$

152. As discussed above, Chile liberalized capital outflows, introduced the URR in 1991, strengthened the URR during the 1990s, and introduced tax incentives for FDI inflows. From Figure $9 \mathrm{a}$, it is clear that the trend in the ratio of short-term capital flows to GDP in Chile started to fall after 1991. Brazil, in contrast, underwent many shifts in policy with regard to capital flows (Agosin and Ffrench-Davis, 1996). For example, in 1991, several policies were adopted to stimulate capital inflows at the same time that voluntary access to foreign capital resumed. Large privatizations were largely responsible for the capital inflows of 1992 . In 1993, taxes on capital inflows along with minimum-length maturity requirements on foreign borrowing were imposed. However, capital inflows continued up until 1995. In mid-1995, several restrictions on inflows were imposed. Despite all those policy changes, Figure $9 \mathrm{~b}$ shows that the trend in the ratio of short-term capital flows to GDP in Brazil remained upward sloping during the period. ${ }^{82}$ Note, however, that there are just two data points after 1995. The third country, Mexico, adopted a more laissez-faire policy to the capital account since the mid-1980s. A downward trend in short-term capital flows in the 1990s is obvious in Mexico (Figure 9c). ${ }^{83}$

153. To summarize, Figures $9 a-c$ illustrate that more research is needed before the downward trend in the ratio of short-term capital flows to GDP in Chile in the 1990s can be attributed to the introduction of the URR with a moderate degree of confidence. A more liberal approach to the capital account in Mexico also seems to be consistent with a falling trend in the ratio of short-term capital flows to GDP during the 1990s. In the Brazilian case, restrictions to capital inflows put in place in 1993 do not seem to have affected the upward trend in the ratio of short-term capital flows to GDP while the short sample available after the restrictions to capital inflows put in place in 1995 makes the assessment difficult. In any case,

\footnotetext{
${ }^{81}$ Data availability restricted the analysis for Mexico to the period 1990 to 1998 . Also, the series for short-term capital flows used for Mexico includes only changes in short-term debt and portfolios flows.

${ }^{82}$ Short-term capital flows include the categories portfolio (net), and other capital inflows (which includes errors and omissions) from the balance of payments statistics.

${ }^{83}$ Short-term capital flows include the categories short-term borrowing, equity investment, and other capital (which includes errors and omissions) of the balance of payments statistics.
} 
Figures 9a-c illustrate the need to disentangle the effects of the URR on short-term capital flows from the effects of other policy changes and nonpolicy changes (such as investors' willingness to lend) on short-term capital flows.

\section{Conclusions and Policy Implications}

154. The main findings and policy implications can be summarized as follows.

- There are important methodological problems in measuring net inflows and short-term capital inflows into Chile in many of the studies reviewed which may undermine some of their results on the impact of the URR on capital flows.

- Looking at the evolution of the various components of capital inflows, it seems that the impact of the URR in reducing specific inflows had only a short-term impact before a shift of transactions on the capital account to untaxed inflows occurred.

- Avoidance by migration via the disintermediation of the taxed domestic banking system may have also been important in reducing the effectiveness of the URR.

- One policy implication of capital controls in Chile may be that controls on capital flows are unstable, i.e., they have to evolve over time to counter the dynamic response of optimizing agents.

- The studies reviewed conclude that: there is some evidence that the URR has been successful in increasing domestic interest rates; there is a relatively weaker evidence that the URR has reduced the magnitude of capital inflows into Chile and altered the composition of capital inflows in favor of medium- and long-term capital inflows; and there is actually no evidence that the URR affected the level of the real exchange rate.

- However, the empirical studies reviewed contain econometric problems that may bias their conclusions either in favor or against the hypothesis of effectiveness of controls on capital inflows in Chile.

- Studies on the effectiveness of the URR in increasing domestic interest rates should control for the impact of the sterilization operations of the monetary authority on domestic real interest rates as part of the increase in interest rates during the life of the URR may have been due to them.

- Studies should also control for the increase in the availability of capital to Latin America in the 1990s as well as for the change in foreigners' willingness to lend following the successful reform of the Chilean economy. Those factors may have increased capital inflows above and reduced domestic interest rates below the levels that would have otherwise prevailed. 
- In Chile as in industrial countries, the removal of controls on capital outflows seems to have influenced the overall volume and structure of net private flows. Direct investment and long-term portfolio investment may have been quite sensitive to changes in control programs. In Chile, changes in regulations affecting capital outflows during the 1990 s may have affected the empirical results reviewed in favor or against the hypothesis of the effectiveness of the URR. As a result, future research trying to assess the impact of the URR on capital inflows requires explicit consideration of changes in those regulations.

- Finally, because there is no clear evidence on the effectiveness of the Chilean URR in achieving its objectives, and because no study has yet assessed empirically the possible benefits and welfare costs of the Chilean URR, it is not possible to judge the net effect of the URR on welfare. 


\section{References}

Agosin, Manuel R. And Ricardo Ffrench-Davis, 1996, "Managing Capital Inflows in Latin America," in M. Haq, I. Kaul, and I. Grunberg, eds., The Tobin Tox: Coping with Financial Volatility.

Baxter, Marianne, 1994, "Real Exchange Rates and Real Interest Rate Differentials: Have We Missed the Business Cycle Relationship?,"Journal of Monetary Economics 33, pp. 5-37.

Calvo, Guillermo, Leonardo Leiderman, and Carmen Reinhart, 1993, "Capital Inflows and Real Exchange Rate Appreciation in Latin America: the Role of External Factors," Staff Papers, International Monetary Fund, Vol. 40 (March), pp. 108-51.

Claessens, Stijn, Dooley, Michael, Warner, Andres, 1995, "Portfolio Capital Flows: Hot or Cold?," World Bank Economic Review, Vol. 9, pp. 53-74.

Dooley, Michael, 1996, “A Survey of the Literature on Controls Over International Capital Transactions," Staff Papers, International Monetary Fund, Vol. 43, (December), pp. 639-87.

Edwards, Sebastian, 1998a, "Capital Flows into Latin America: A Stop-Go Story," National Bureau of Economic Research, No. 6441, (March).

_ , 1998b, "Capital Flows, real Exchange Rates, and Capital Controls: Some Latin American Experiences," (unpublished; University of California at Los Angeles).

and Alejandra Cox, 1997, "Monetarism and Liberalization: The Chilean Experience," Cambridge, Mass., Ballinger.

Eichengreen Barry, James Tobin, and Charles Wyplosz, 1995, "Two Cases for Sand in the Wheels of International Finance," The economic Journal 105, pp. 162-72.

Eichengreen, Barry and Charles Wyplosz, 1996, "Taxing International Financial Transactions to Enhance the Operation of the International Monetary System," in M. Haq, I. Kaul, and I. Grunberg, eds. The Tobin Tax:Coping with Financial Volatility, Oxford: Oxford University Press.

Eichengreen, Barry and Michael Mussa with Giovanni Dell'Ariccia, Enrica Detragiache, Gian Maria Milesi-Ferretti, and Andrew Tweedie, 1998, "Capital Account Liberalization Theoretical and Practical Aspects," Occasional Paper No. 172, International Monetary Fund. 
Eyzaguirre, Nicolás and Klaus Schmidt-Hebbel, 1997, "Encaje a la Entrada de Capitales y Ajuste Macroeconómico," (unpublished; Central Bank of Chile).

Frankel, Jeffrey, 1996, "How Well Do Markets Work: Might a Tobin Tax Help?," in M. Haq, I. Kaul, and I. Grunberg, eds. The Tobin Tax: Coping with Financial Volatility, Oxford: Oxford University Press.

Haq, Mahbub, Inge Kaul and Isabelle Grunberg, eds., 1996, The Tobin Tax: Coping with Financial Volatility, Oxford: Oxford University Press.

Herrera, Luis Oscar and Rodrigo Valdés-Prieto, 1997, "Encaje y Autonomía Monetaria en Chile," (unpublished; Central Bank of Chile).

Johnston, Barry, and Chris Ryan, 1994, "The Impact of Controls on Capital Movements on the Private Capital Accounts of Countries' balance of Payments: Empirical Estimates and Policy Implications," IMF Working Paper No. 94/78 (Washington: International Monetary Fund).

Labán, Raúl and Felipe Larraín, 1994, "The Chilean Experience with Capital Mobility." In B. Bosworth, R. Dornbusch and R. Labán (eds.). The Chilean Economy: Policy Lessons and Challenges, The Brookings Institution.

Labán, Raúl and Felipe Larraín, 1997, "Can a Liberalization of Capital Outflows Increase Net Capital Inflows?," Journal of International Money and Finance Vol. 16, (June), pp. 415-31.

_ 1998, “The Return of Private Capital to Chile in the 1990s: Causes, Effects, and Policy Reactions," Working Paper R98-02, Harvard University.

Laurens, Bernard and Jaime Cardoso, 1998, "Managing Capital Flows: Lessons from the Experience of Chile," (unpublished; Washington: Monetary and Exchange Affairs Department, International Monetary Fund).

Le Fort, Guillermo and Carlos Budnevich, 1996, "Capital Account Regulations and Macroeconomic Policy: Two Latin Experiences," The Jerome Levy Economics Institute of Bard College Working Paper No. 162 (Washington: The Jerome Levy Economics Institute of Bard College).

- and Gonzalo Sanhueza, 1997, "Flujo de Capitales y Encaje en la Experiencia Chilena de los 90," (unpublished; Central Bank of Chile).

Massad, Carlos, 1998, "The Liberalization of the Capital Account: Chile in the 1990s," Essays in International Finance No. 207, (May), Princeton University, pp. 34-46. 
Meese, Richard, 1990, "Currency Fluctuations in the Post-Bretton Woods Era," Journal of Economic Perspectives 4, (Winter), pp. 117-34.

Nadal-De Simone, Francisco, 1997, "The Tobin Tax: Coping with Financial Volatility. A Review Article," Singapore Economic Review, Vol. 42, (April). and Weshah Razzak, 1998, "The Long-Run Nominal Exchange Rate: An Alternative Model and Empirical Evidence," (unpublished; Reserve Bank of New Zealand).

Obstfeld, Maurice, 1995, "International Capital Mobility in the 1990s," in Peter Kenen, ed. Understanding Interdependence: the Macroeconomics of the Open Economy, Princeton, New Jersey: Princeton University Press.

Quirk, Peter, and Owen, Evans, 1995, Capital account Convertibility: Review of Experience and Implications for Fund Policies, IMF Occational paper No. 131 (Washington: International Monetary Fund).

Schadler, Susan, Maria Carcovic, Adam Bennett, and Robert Kahn, 1993, Recent Experiences with Surges in Capital Inflows, IMF, Occational paper No. 108 (Washington: International Monetary Fund).

Soto, Claudio, 1997, "Controles a los Movimientos de Capital: Evaluación Empírica del Caso Chileno," (unpublished; Central Bank of Chile).

Tobin James, 1978, "A Proposal for International Monetary reform," Eastern Economic Journal 4, pp. 153-59.

Ullah, A. And H. D. Vinod, 1993, "General Nonparametric Regression Estimation and Testing in Econometrics," in G.S. Maddala, C. R. Rao and H. D. Vinod, eds., Handbook of Statistics, Vol. 11, pp. 85-116, Holland: Elsevier Science Publishers B.V.

Valdés-Prieto, Salvador, and Marcelo Soto, 1997, "The Effectiveness of Capital Controls: Theory and Evidence from Chile," (unpublished; Universidad Católica de Chile).

Williamson, John, 1991, On Liberalizing the Capital Account, AMEX Bank Review. Oxford University Press.

Zahler, Roberto, 1998, "Chile's Macroeconomic Policies in the 1990s as Seen from the Vantage Point of the Central Bank," United Nations, Economic Commission for Latin America and the Caribbean-ECLAC, LC/L 1140, (September). 


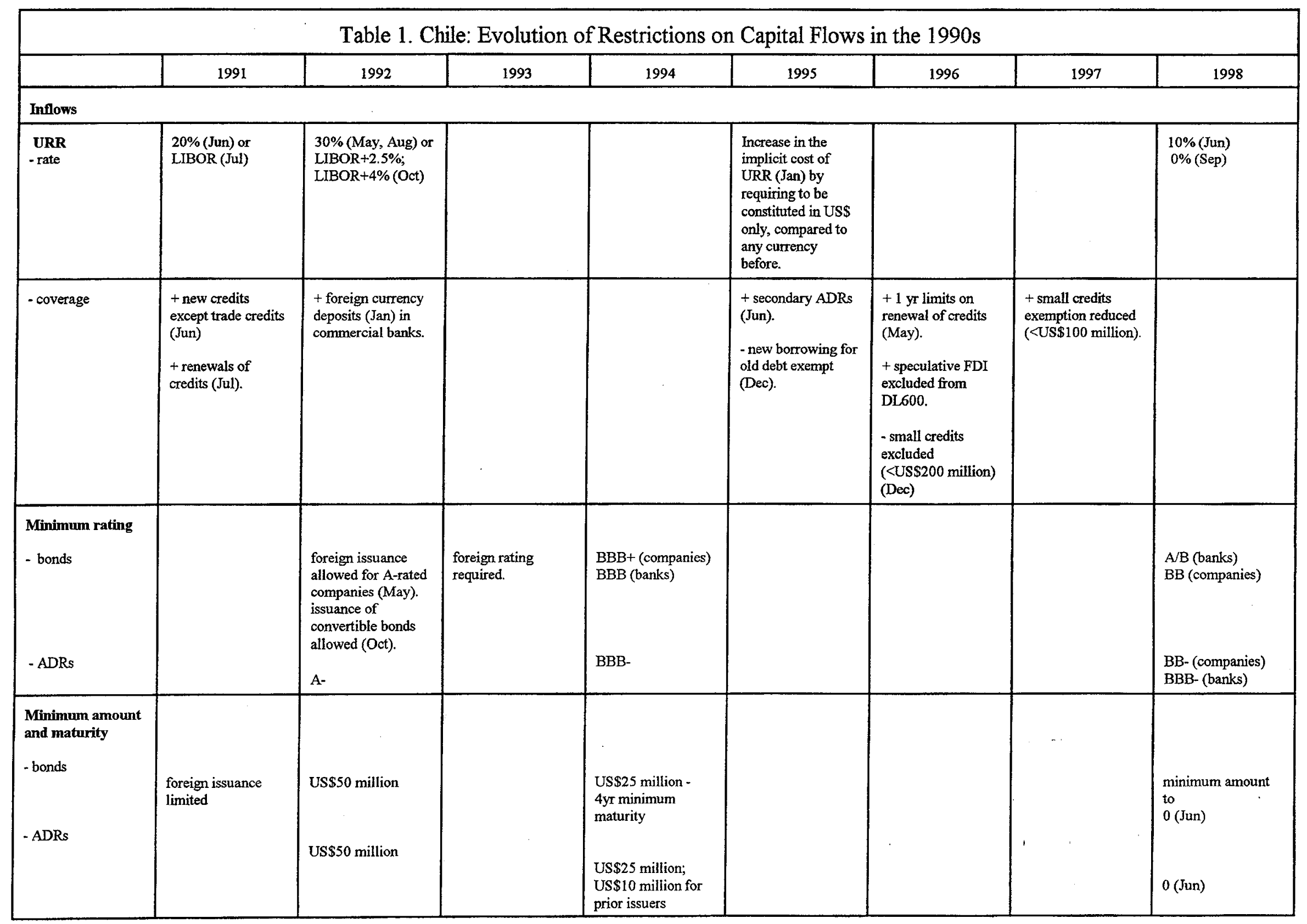




\begin{tabular}{|c|c|c|c|c|c|c|c|c|}
\hline $\begin{array}{l}\text { - banks } \\
\text {-FDI }\end{array}$ & & $\begin{array}{l}\text { limits on forex } \\
\text { holdings increased }\end{array}$ & US\$1 million & & & & & \\
\hline \multicolumn{9}{|l|}{ Outflows } \\
\hline - pension fund rules & & $\begin{array}{l}\text { for asset ownership } \\
\text { allowed up to } 1.5 \% \\
\text { of assets (Jan). }\end{array}$ & & $\begin{array}{l}\text { increased to 6\% } \\
\text { (Nov) }\end{array}$ & $\begin{array}{l}\text { increased to } 9 \% \\
\text { (May) }\end{array}$ & $\begin{array}{l}\text { limit can be } \\
\text { increased to } 12 \% \\
\text { (Apr) }\end{array}$ & & \\
\hline - commercial banks & $\begin{array}{l}25 \% \text { of forex } \\
\text { deposits can be inv. } \\
\text { abroad (Feb) } \\
\text { trade financing } \\
\text { included in above } \\
\text { limit increased to } \\
40 \% \text { (Apr) }\end{array}$ & $\begin{array}{l}\text { limit increased to } \\
80 \% \text { (Mar). }\end{array}$ & & $\begin{array}{l}\text { can invest in for. } \\
\text { banks } 20 \% \text { of } \\
\text { capital and } \\
\text { reserves; risk } \\
\text { weighted assets } 10 \\
\text { times total equity } \\
\text { (Sep). }\end{array}$ & & & 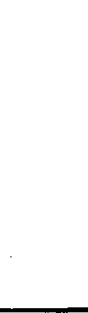 & $\begin{array}{l}\text { FDI limit increased } \\
\text { to } 40 \% \text { of capital in } \\
\text { one country or } 70 \% \\
\text { of capital overall. }\end{array}$ \\
\hline - outward FDI & $\begin{array}{l}\text { procedures eased } \\
\text { and FDI allowed } \\
\text { with own forex or } \\
\text { via informal market }\end{array}$ & & & & & & & \\
\hline $\begin{array}{l}\text { - mutual funds and } \\
\text { other }\end{array}$ & & & & $\begin{array}{l}\text { insurance } \\
\text { companies for inv. } \\
\text { limits incr. to } 10 \% \text {, } \\
\text { mutual funds to } \\
\mathbf{3 0 \%}\end{array}$ & & & & $\begin{array}{l}\text { mutual fuind limit } \\
\text { eliminated (Jun) }\end{array}$ \\
\hline
\end{tabular}


Table 2. Chile: Summary of Selective Quantitative Studies on the Effects of the URR on Capital Inflows 1/2/

\begin{tabular}{|c|c|c|c|c|c|c|}
\hline Author & Data & Capital Flow Measure Used & $\begin{array}{c}\text { Domestic Interest } \\
\text { Rate - Interest } \\
\text { Rate Differential } \\
\text { (1) } \\
\end{array}$ & $\begin{array}{l}\text { Magnitude of } \\
\text { Capital Flows } \\
\text { (2) }\end{array}$ & $\begin{array}{c}\text { Real } \\
\text { Exchange } \\
\text { Rate } \\
(3) \\
\end{array}$ & $\begin{array}{l}\text { Ratio of } \\
\text { Short-Term to } \\
\text { Long-Term } \\
\text { Capital Flows } \\
\text { (4) }\end{array}$ \\
\hline $\begin{array}{l}\text { 1. Eyzaguirre \& } \\
\text { Schmidt-Hebbel } \\
\text { (1997) }\end{array}$ & $\begin{array}{l}\text { Monthly } \\
1991 / 1- \\
1996 / 6\end{array}$ & $\begin{array}{l}\text { a) Changes in central bank reserves less } \\
\text { cummulated net foreign liabilities of the } \\
\text { capital account } \\
\text { b) Ratio of short-term to medium- and } \\
\text { long-term gross foreign liabilities }\end{array}$ & & $\begin{array}{l}\text { Positive } \\
\text { (Indirect) }\end{array}$ & & Negative \\
\hline $\begin{array}{l}\text { 2. Herrera \& } \\
\text { Valdés-Prieto } \\
\text { (1997) }\end{array}$ & $\begin{array}{l}\text { Monthly } \\
1991 / 1- \\
1996 / 8\end{array}$ & & Positive & & & \\
\hline $\begin{array}{l}\text { 3. Valdés-Prieto \& } \\
\text { Soto } \\
\text { (1997) }\end{array}$ & $\begin{array}{c}\text { Quarterly } \\
1987 / 4 \\
1996 / 4 \\
\end{array}$ & $\begin{array}{l}\text { Net short-term credit inflows to the } \\
\text { private sector plus errors and omissions }\end{array}$ & & & & Negative $3 /$ \\
\hline $\begin{array}{l}\text { 4. Soto } \\
\text { (1997) }\end{array}$ & $\begin{array}{l}\text { Monthly } \\
1991 / 1- \\
1996 / 6\end{array}$ & $\begin{array}{l}\text { a) Total net capital flows } \\
\text { b) Ratio of short-term net debt to } \\
\text { medium- and long-term net debt }\end{array}$ & $\begin{array}{c}\text { Positive } \\
\text { (In the medium term) }\end{array}$ & $\begin{array}{c}\text { Positive } \\
\text { (On impact) } \\
\text { Negative } \\
\text { (In the short term) }\end{array}$ & $\begin{array}{c}0 \\
\text { (Level) } \\
\text { Negative } \\
\text { (Volatility) }\end{array}$ & $\begin{array}{l}\text { Negative } \\
\text { (In the } \\
\text { medium term) }\end{array}$ \\
\hline $\begin{array}{l}\text { 5. Edwards } \\
\text { (1998) }\end{array}$ & $\begin{array}{c}\text { Quarterly } \\
1981 / 1- \\
1996 / 6\end{array}$ & Changes in reserves of the central bank & $\begin{array}{c}\text { Positive } \\
\text { (In the short term) }\end{array}$ & . & 0 & \\
\hline $\begin{array}{l}\text { 6. Laurens \& } \\
\text { Cardoso } \\
(1998)\end{array}$ & $\begin{array}{l}\text { Quarterly } \\
1985 / 1- \\
1994 / 4\end{array}$ & $\begin{array}{l}\text { Net short-term and medium- and long- } \\
\text { term capital inflows }\end{array}$ & & $\begin{array}{c}\text { Negative 3/ } \\
\text { (In the short term) }\end{array}$ & & $\begin{array}{c}\text { Negative 3/ } \\
\text { (In the short term) } \\
\text { Positive 3/ } \\
\text { (In the } \\
\text { medium term) } \\
\text { Negative 4/ } \\
\text { (In the medium } \\
\text { term) }\end{array}$ \\
\hline
\end{tabular}

1/ This table reports only those results that the authors consider to be robust.

$2 /$ The words "positive" and "negative" refer to the sign of the effect of the URR on the variable analyzed in the corresponding column.

$3 /$ The variable used is short-term capital inflows.

4/ The variable used is medium- and long-term capital inflows. 
Table 3. Chile: Assessment of Selective Quantitative Studies on the Effects of the URR on Capital Inflows in Chile 1/2/

\begin{tabular}{|c|c|c|c|c|c|c|c|c|c|c|c|c|}
\hline \multirow[b]{2}{*}{ Author } & \multicolumn{2}{|c|}{ Model } & \multicolumn{2}{|c|}{ Unit-root } & \multicolumn{2}{|c|}{ Cointegration } & \multirow[b]{2}{*}{ Estimator } & \multirow[b]{2}{*}{$\begin{array}{l}\text { Goodness } \\
\text { of Fit }\left(R^{2}\right)\end{array}$} & \multicolumn{2}{|c|}{$\begin{array}{c}\text { Serial } \\
\text { Correlation Test }\end{array}$} & \multirow[b]{2}{*}{$\begin{array}{l}\text { Robustness of } \\
\text { Estimation }\end{array}$} & \multirow[b]{2}{*}{ Comments } \\
\hline & $\begin{array}{c}\text { Uni- } \\
\text { variate }\end{array}$ & $\begin{array}{l}\text { Multi- } \\
\text { variate }\end{array}$ & Testing & Reporting & Testing & Reporting & & & Result & Biased & & \\
\hline $\begin{array}{l}1 . \\
\text { Eyzaguirre } \\
\text { \& Schmidt- } \\
\text { Hebbel } \\
(1997)\end{array}$ & & Yes & Yes & Yes & Yes & No & $\begin{array}{l}\text { (1) (2) (4) Two- } \\
\text { stage least } \\
\text { squares } \\
\text { (1) (3) Error- } \\
\text { correction } \\
\text { maximum in } \\
\text { likelihood }\end{array}$ & $\begin{array}{l}(1) \\
0.67-0.98 \\
(2) \\
0.79-0.82 \\
(3) \\
0.27-0.30 \\
(4) \\
0.86-0.99\end{array}$ & $\begin{array}{l}\text { Yes } \\
\text { Yes } \\
\text { No } \\
\text { Yes }\end{array}$ & $\begin{array}{l}\text { No } \\
\text { Yes } \\
\text { Yes } \\
\text { Yes }\end{array}$ & $\begin{array}{l}\text { (1) Inefficient } \\
\text { (2) Biased } \\
\text { (3) Inefficient } \\
\text { (4) Biased }\end{array}$ & $\begin{array}{l}\text { In (1) and (2), dependent and } \\
\text { independent variables have different } \\
\text { orders of integration }\end{array}$ \\
\hline $\begin{array}{l}2 . \\
\text { Herrera \& } \\
\text { Valdés- } \\
\text { Prieto } \\
\text { (1997) }\end{array}$ & Yes & & Yes & No & No & - & $\begin{array}{l}\text { Ordinary least } \\
\text { squares. } \\
\text { Maximum } \\
\text { likelihood }\end{array}$ & $\begin{array}{l}0.83-093 \\
\text { Likelihood } \\
\text { ratio } \\
\text { accepts all } \\
\text { regressors } \\
\text { are not zero } \\
\text { for weekly } \\
\text { data; } \\
\text { rejects it for } \\
\text { monthly } \\
\text { data }\end{array}$ & No test & & Yes & \\
\hline $\begin{array}{l}3 . \\
\text { Valdés- } \\
\text { Prieto \& } \\
\text { Soto } \\
(1997) \\
\end{array}$ & Yes & & Yes & No & No & - & $\begin{array}{l}\text { Instrumental } \\
\text { variables }\end{array}$ & $0.36-0.56$ & No & Yes & Biased & $\begin{array}{l}\text { Variables are likely to be of } \\
\text { different orders of integration }\end{array}$ \\
\hline $\begin{array}{l}4 . \\
\text { Soto } \\
\text { (1997) }\end{array}$ & & Yes & No & - & No & - & $\begin{array}{l}\text { Ordinary least } \\
\text { squares }\end{array}$ & & No test & & No & $\begin{array}{l}\text { - Systems in (1) (2) and (3) are } \\
\text { under-identified } \\
\text { - No information on the number of } \\
\text { regressors in each equation } \\
\text { - No test of block exogeneity } \\
\text { - No test of effect of changes in } \\
\text { ordering of regressors on the } \\
\text { relationship among the variables } \\
\text { - No allowance for cointegration; } \\
\text { possible misspecification problems }\end{array}$ \\
\hline
\end{tabular}


Table 3. Chile: Assessment of Selective Quantitative Studies on the Effects of the URR on Capital Inflows in Chile 1/2/

\begin{tabular}{|c|c|c|c|c|c|c|c|c|c|c|c|c|}
\hline \multirow[b]{2}{*}{ Author } & \multicolumn{2}{|c|}{ Model } & \multicolumn{2}{|c|}{ Unit-root } & \multicolumn{2}{|c|}{ Cointegration } & \multirow[b]{2}{*}{ Estimator } & \multirow[b]{2}{*}{$\begin{array}{l}\text { Goodness } \\
\text { of Fit }\left(R^{2}\right)\end{array}$} & \multicolumn{2}{|c|}{$\begin{array}{c}\text { Serial } \\
\text { Correlation Test }\end{array}$} & \multirow[b]{2}{*}{$\begin{array}{c}\text { Robustness of } \\
\text { Estimation }\end{array}$} & \multirow[b]{2}{*}{ Comments } \\
\hline & $\begin{array}{c}\text { Uni- } \\
\text { variate }\end{array}$ & $\begin{array}{l}\text { Multi- } \\
\text { variate }\end{array}$ & Testing & Reporting & Testing & Reporting & & & Result & Biased & & \\
\hline $\begin{array}{l}5 . \\
\text { Edwards } \\
\text { (1998) }\end{array}$ & $\begin{array}{l}\text { (1) Yes } \\
\text { (1) Yes }\end{array}$ & $\begin{array}{l}\text { (1) (2) } \\
\text { Yes }\end{array}$ & $\begin{array}{l}\text { No } \\
\text { No }\end{array}$ & - & $\begin{array}{l}\text { No } \\
\text { N.A } \\
\text { N.A }\end{array}$ & - & $\begin{array}{l}\begin{array}{l}\text { Ordinary least } \\
\text { squares }\end{array} \\
\begin{array}{l}\text { Ordinary least } \\
\text { squares }\end{array} \\
\text { Rolling } \\
\text { regression }\end{array}$ & 0.23 & $\begin{array}{l}\text { No test } \\
\text { Yes } \\
\text { Yes }\end{array}$ & $\begin{array}{l}\text { No } \\
\text { Yes }\end{array}$ & $\begin{array}{l}\text { (1) (2) No } \\
\text { (1) Yes } \\
\text { (1) No }\end{array}$ & $\begin{array}{l}\text { - VARs use the cyclical part of the } \\
\text { series obtained by a Hodrick- } \\
\text { Prescott filter with unspecified } \\
\text { smoother } \\
\text { - Ordering does not affect results } \\
\text { - System is not identified } \\
\text { - No infomation on lag-length } \\
\text { choice } \\
\text { - No information on number of } \\
\text { regressors in each equation } \\
\text { - No allowance for cointegration }\end{array}$ \\
\hline $\begin{array}{l}6 . \\
\text { Laurens \& } \\
\text { Cardoso } \\
\text { (1998) }\end{array}$ & Yes & & No & & No & - & $\begin{array}{l}\text { Ordinary least } \\
\text { squares }\end{array}$ & $\begin{array}{l}(2) \\
53.1-61.0 \\
(4) \\
53.1-71.5\end{array}$ & No test & & No & $\begin{array}{l}\text { - Unclear alternative hypothesis (the } \\
\text { null hypothesis is that the URR } \\
\text { affects total net inflows and short- } \\
\text { term inflows negatively) } \\
\text { - Variables are possibly of different } \\
\text { levels of integration } \\
\text { - Possible simultaneity bias } \\
\text { - Low } R^{2}\end{array}$ \\
\hline
\end{tabular}

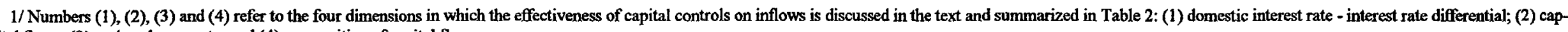
ital flows; (3) real exchange rate; and (4) composition of capital flows.

$2 / \mathrm{A}$ (?) Indicates that there is not enough information provided to assess the issue. 
Figure 1. Chile: Components of Gross Capital Outflows

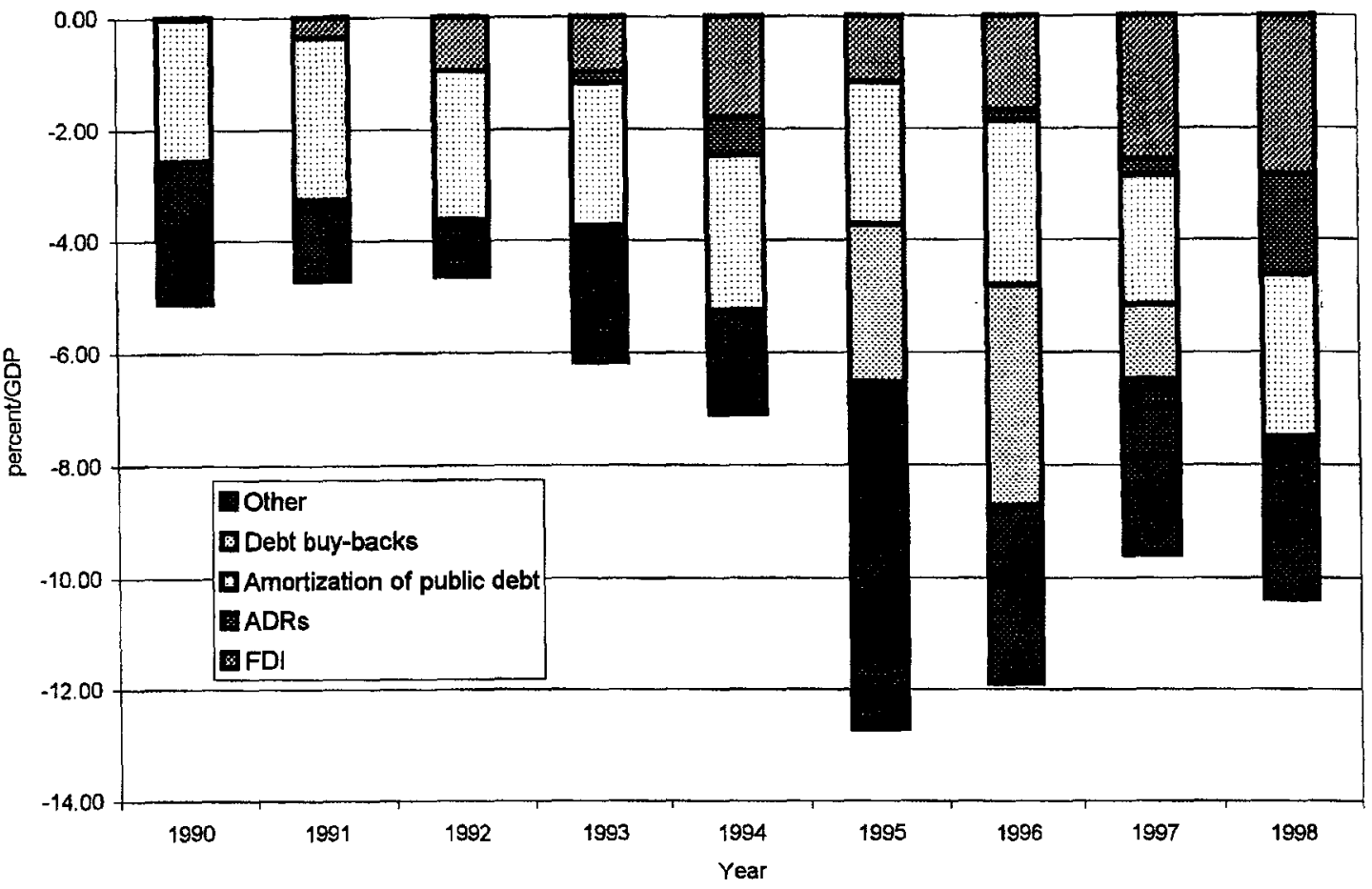

Figure 2. Chile: Different Definitions of Capital Inflows

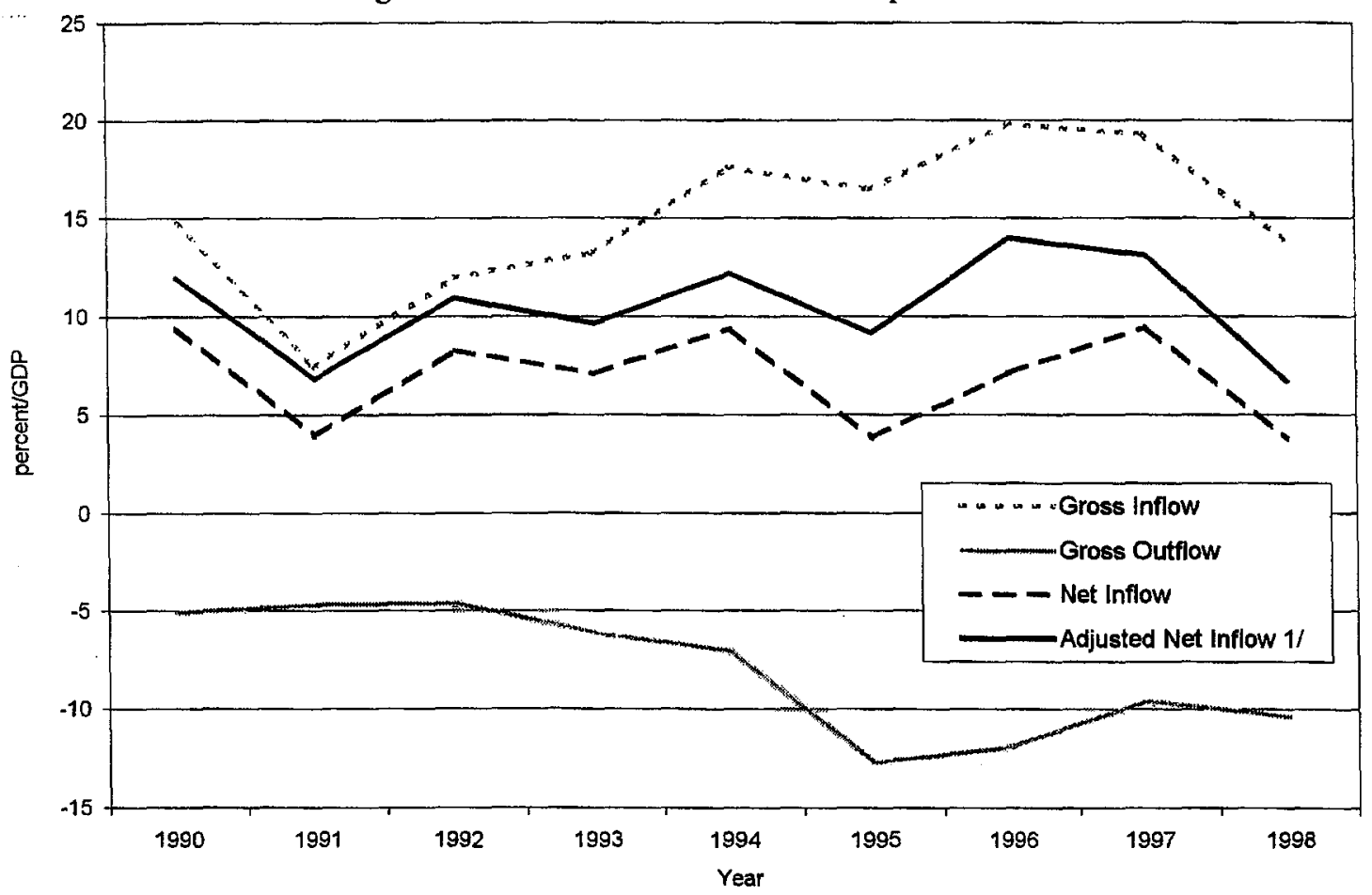

Sources: Central Bank of Chile; and Fund staff estimates.

1/ Adjusted net inflows=Net inflow less debt pre-payments , 
Figure 3. Chile: Share of URR-covered Flows in Gross Capital Inflows

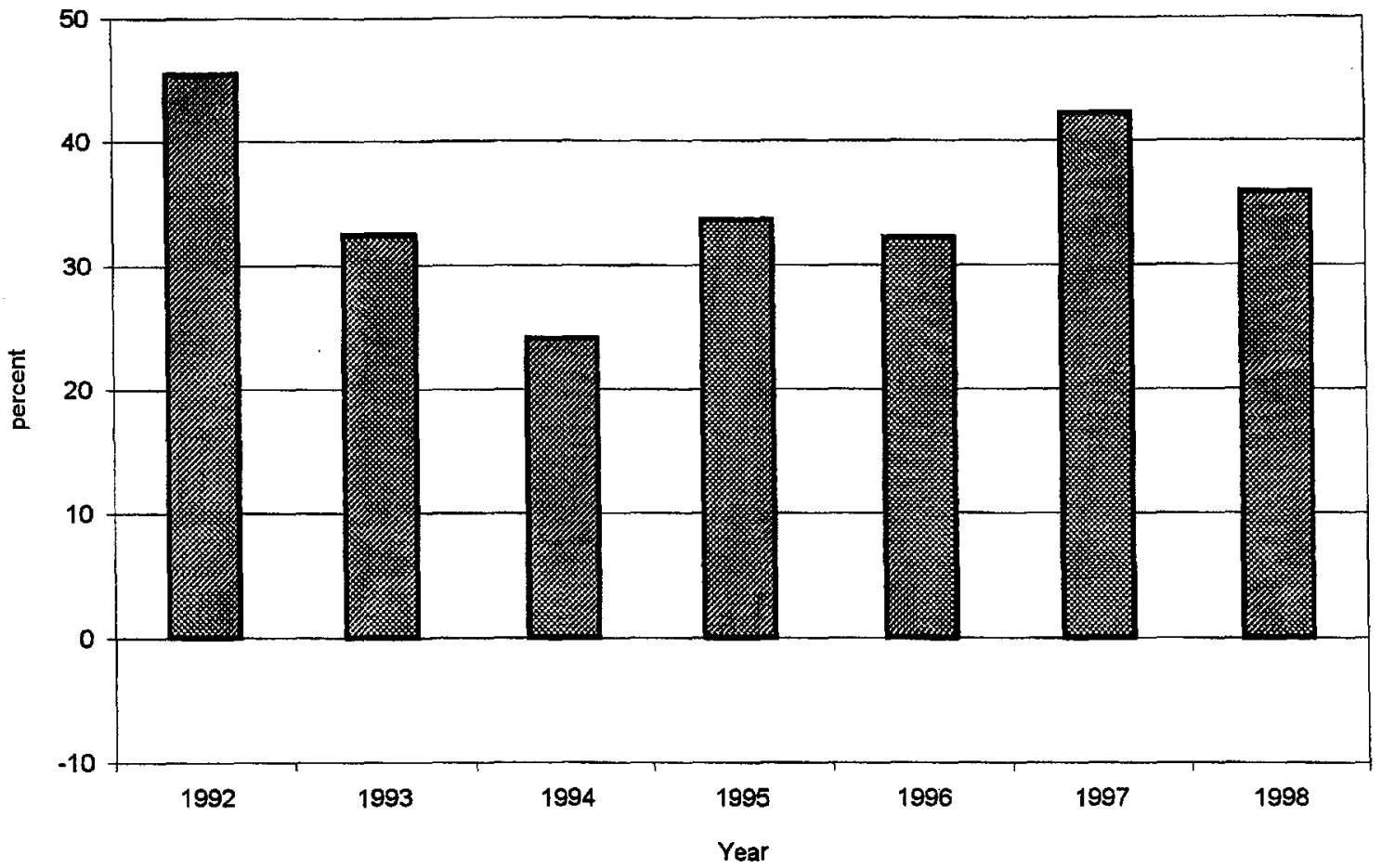

Figure 4. Chile: URR Tightening (1991, 1995, 1996) and Behaviour of Affected Gross Inflows

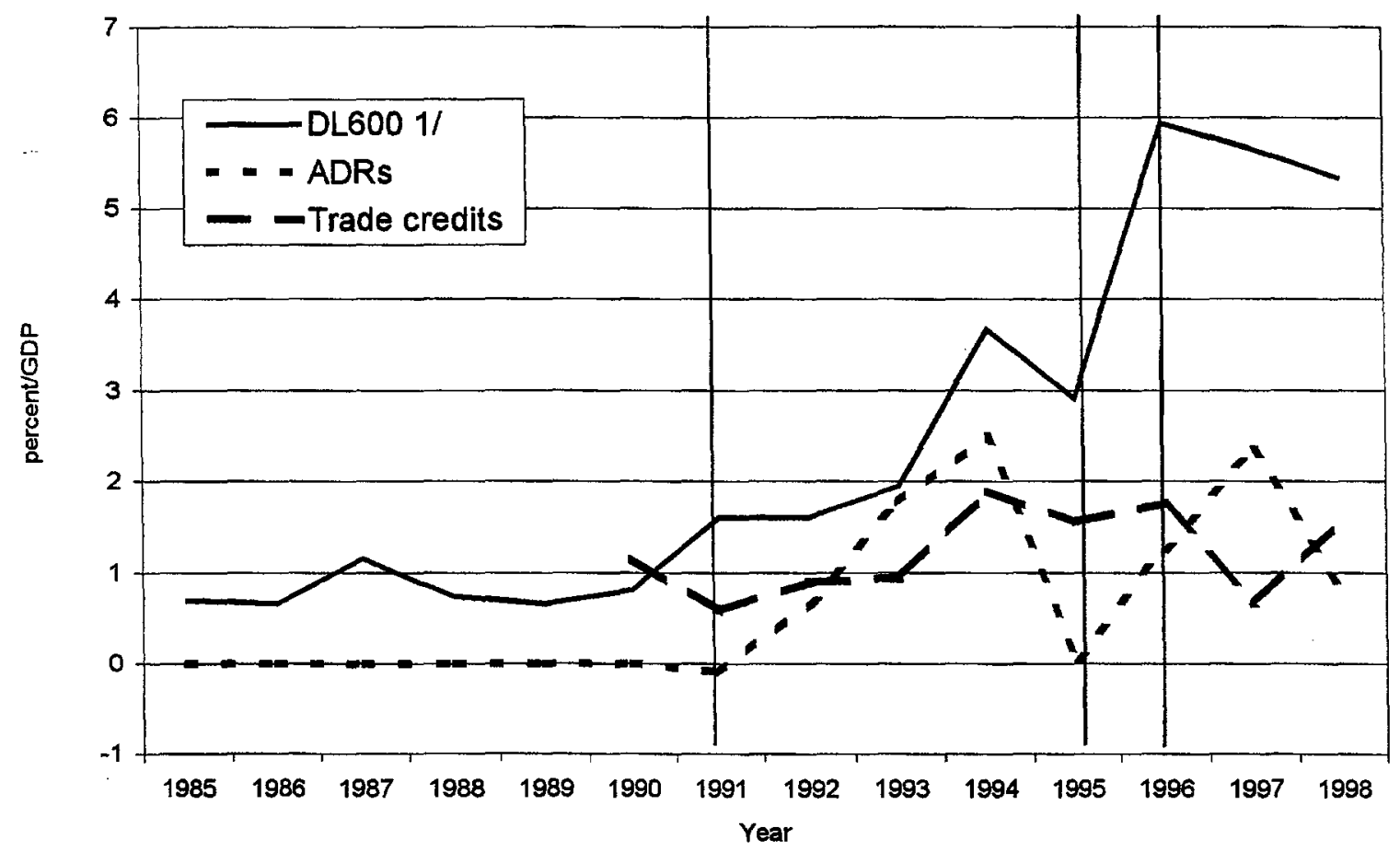

Sources: Central Bank of Chile; and Fund staff estimates.

1/ DL600-FDI receiving special incentives. 
Figure 5a. Chile: Net Short-term Capital Flows - Total, Debt and Nondebt Flows

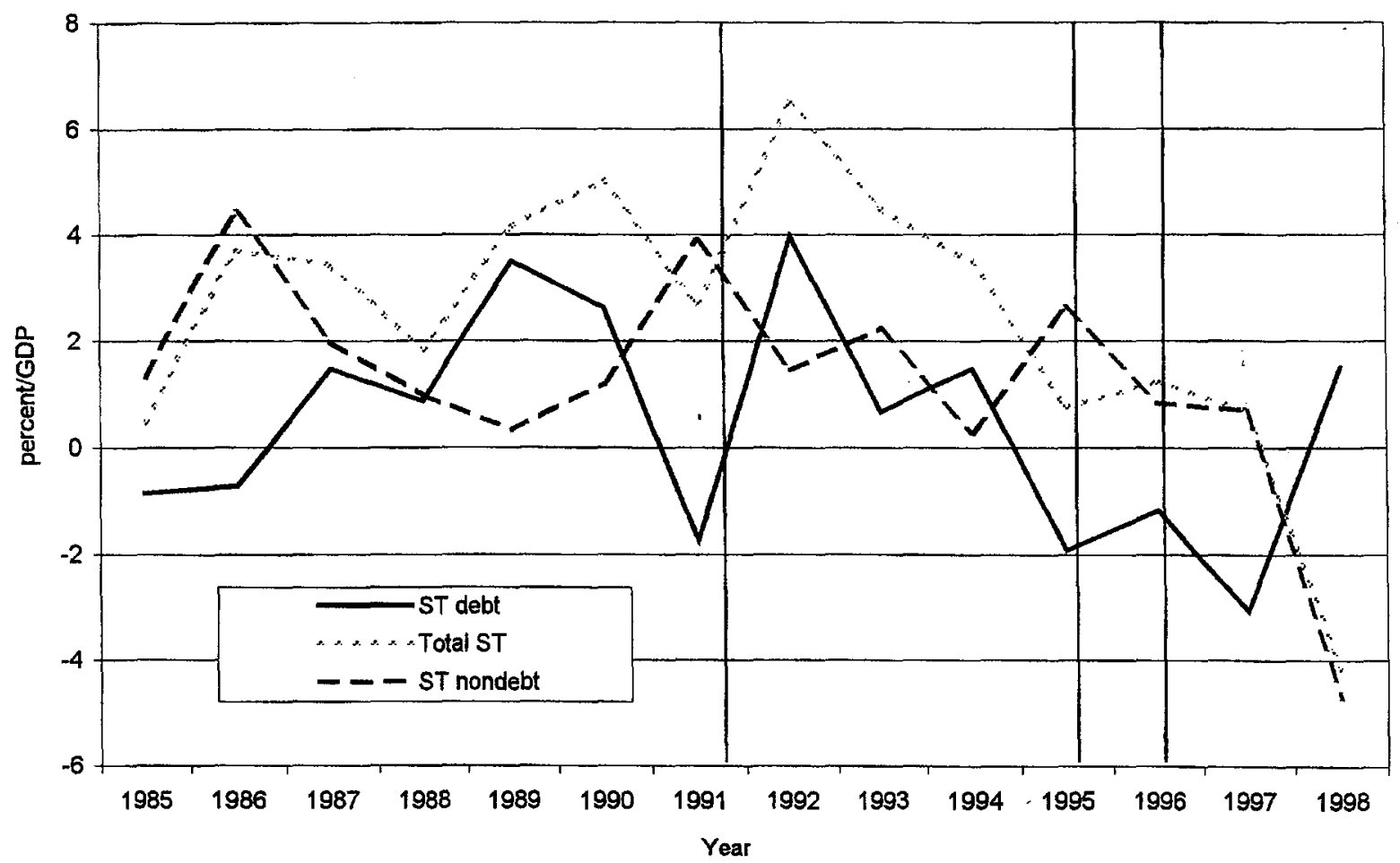

Figure 5b. Chile: Structure of Foreign Capital

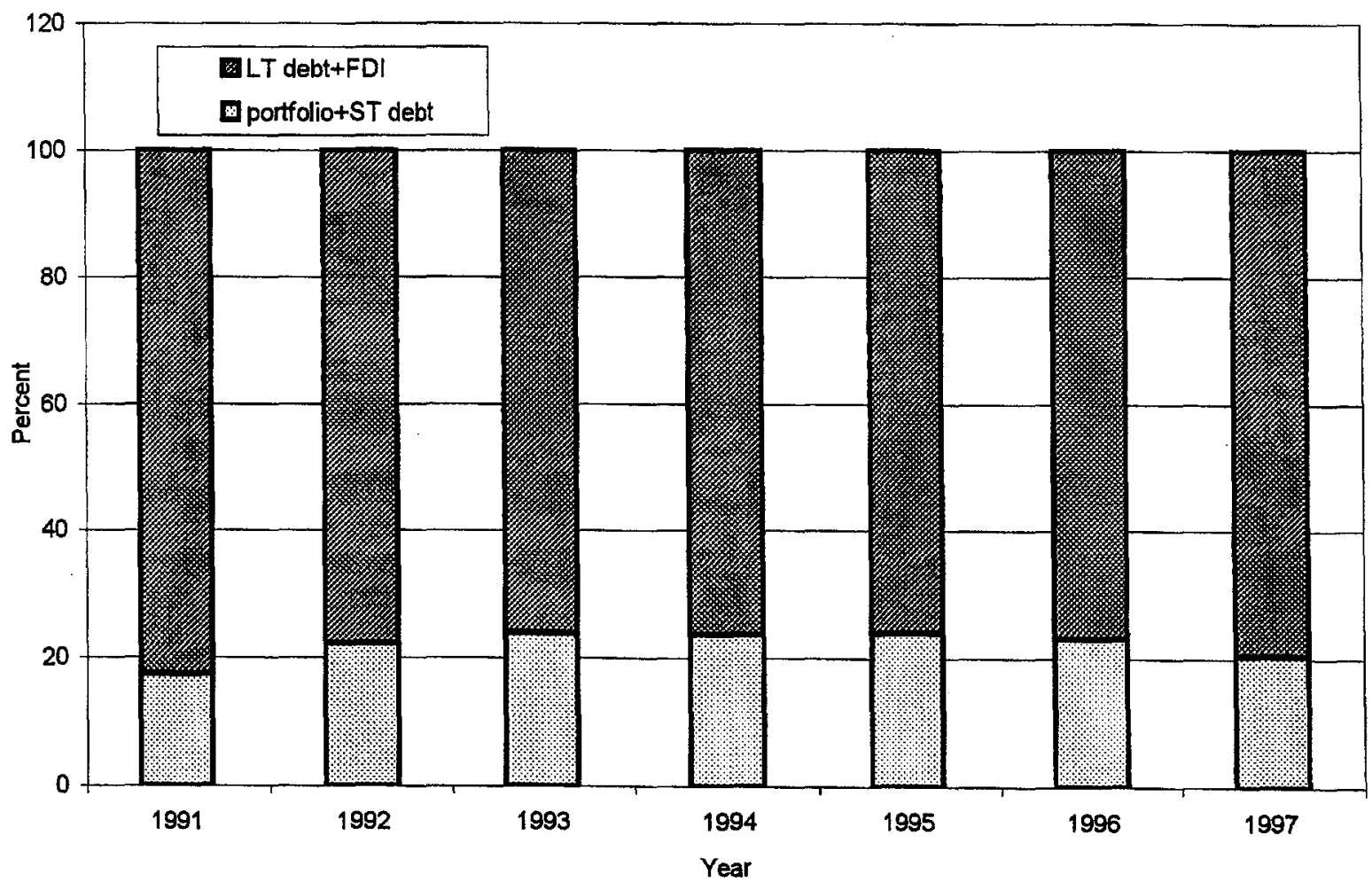

Sources: Central Bank of Chile; and Fund staff estimates. 
Figure 6. Chile: Capital Account Ratio to GDP:

Trend and Cyclical Components

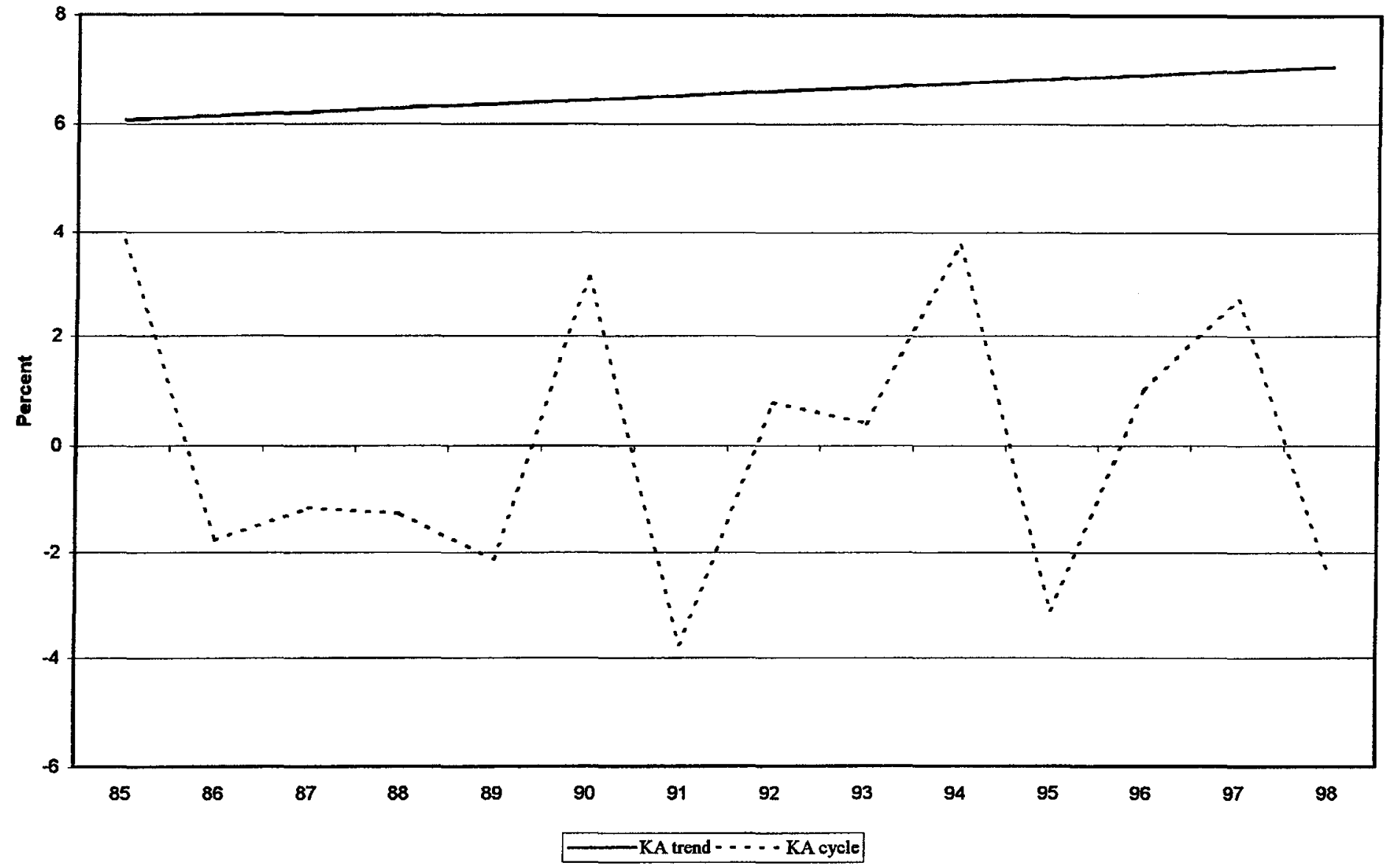

Sources: Central Bank of Chile; and Fund staff estimates 
Figure 7. Chile: Capital Inflow and Outflow Ratios to GDP: Trend and Cyclical Components

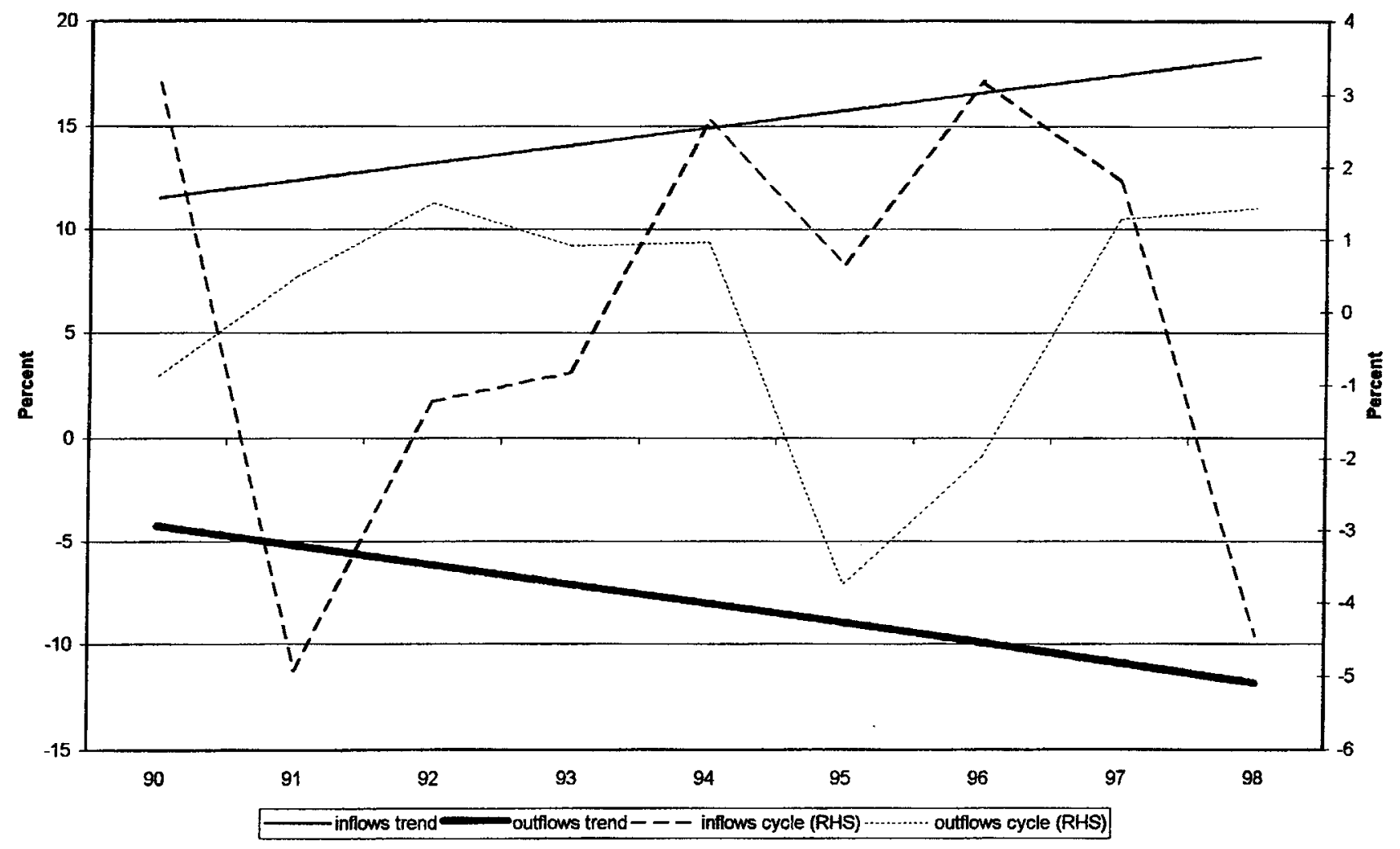

Sources: Central Bank of Chile; and Fund staff estimates. 
Figure 8a. Chile: Domestic Minus Foreign Real Interest Rates and Changes in the Real Effective Exchange Rate Lagged One Year:

Cyclical Components

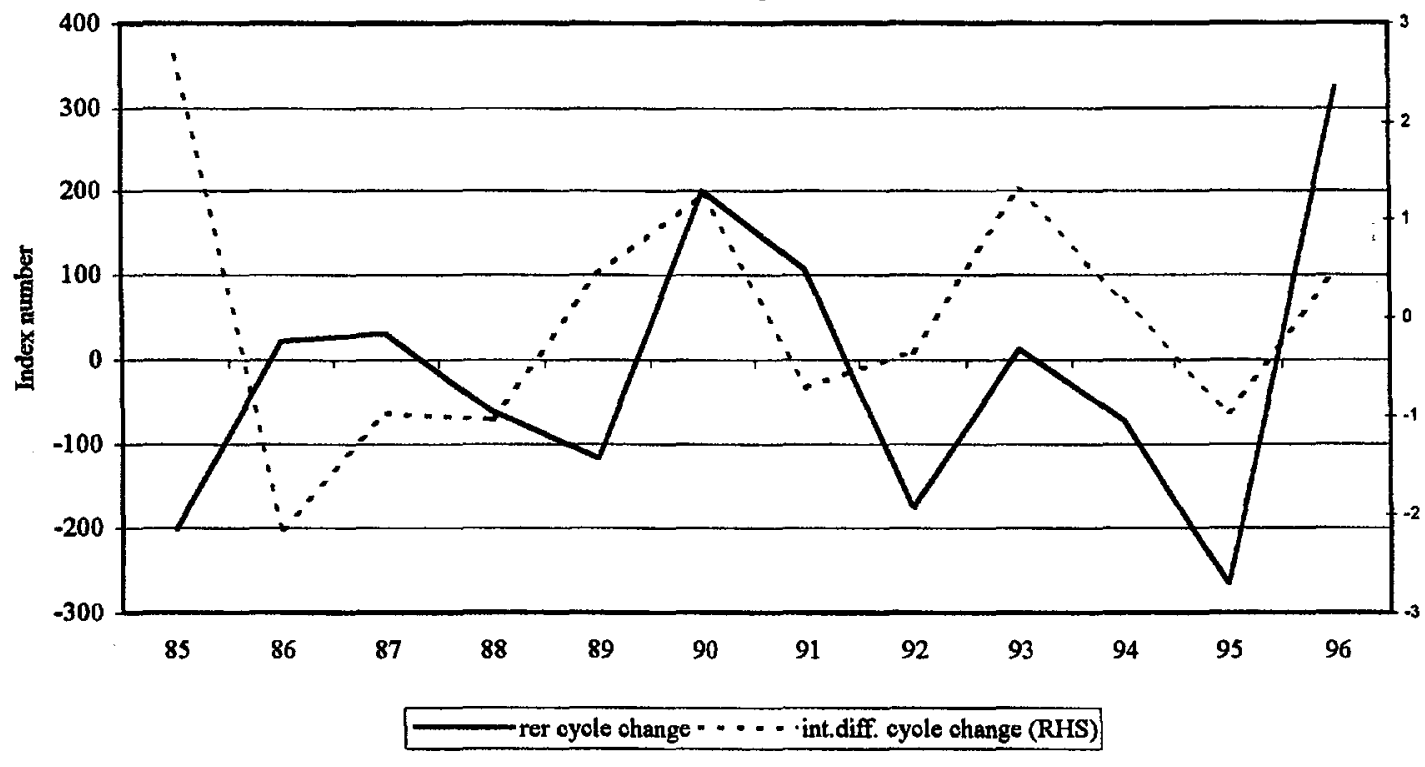

Figure 8b. Chile: Domestic Minus Foreign Potential Output Growth and Changes in the Real Effective Exchange Rate: Trend Components

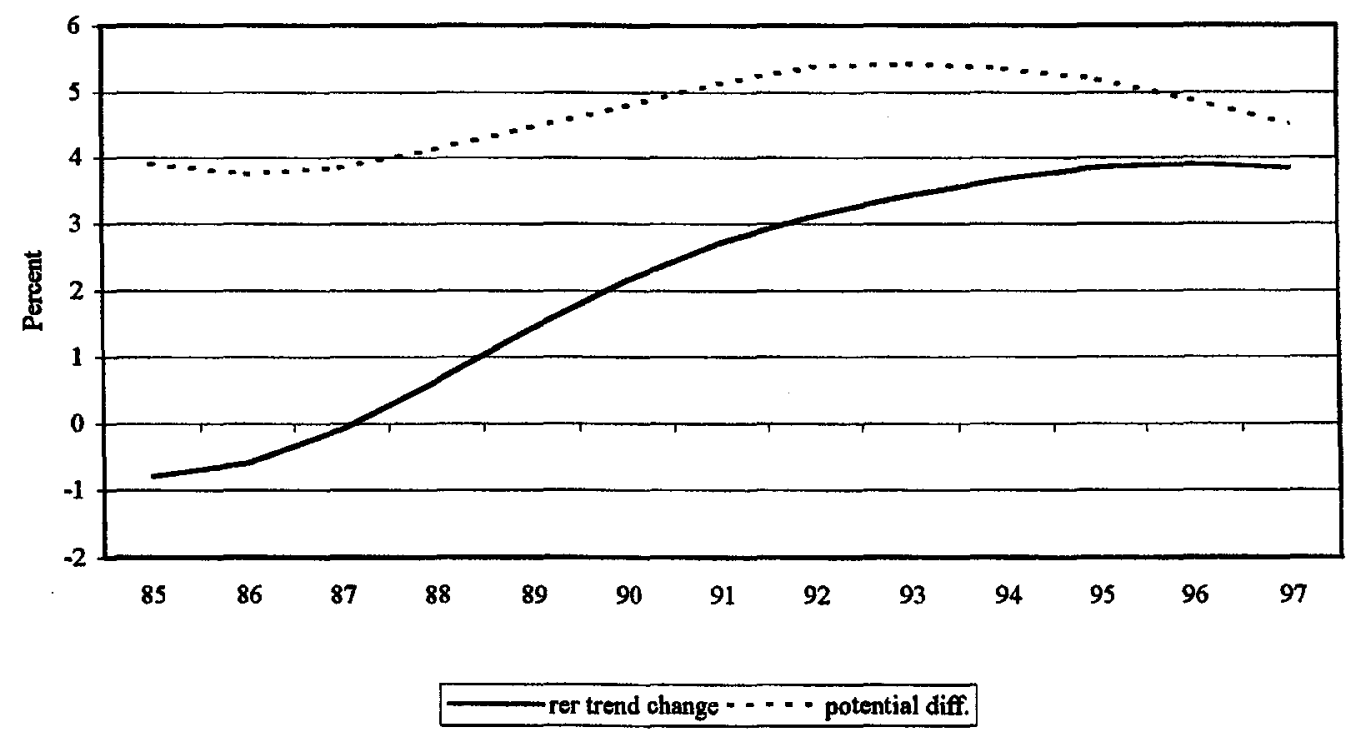

Sources: Central Bank of Chile; and Fund staff estimates 
Figure 9a. Chile: Short-term Capital Flow Ratio to GDP: Trend and Cyclical Components

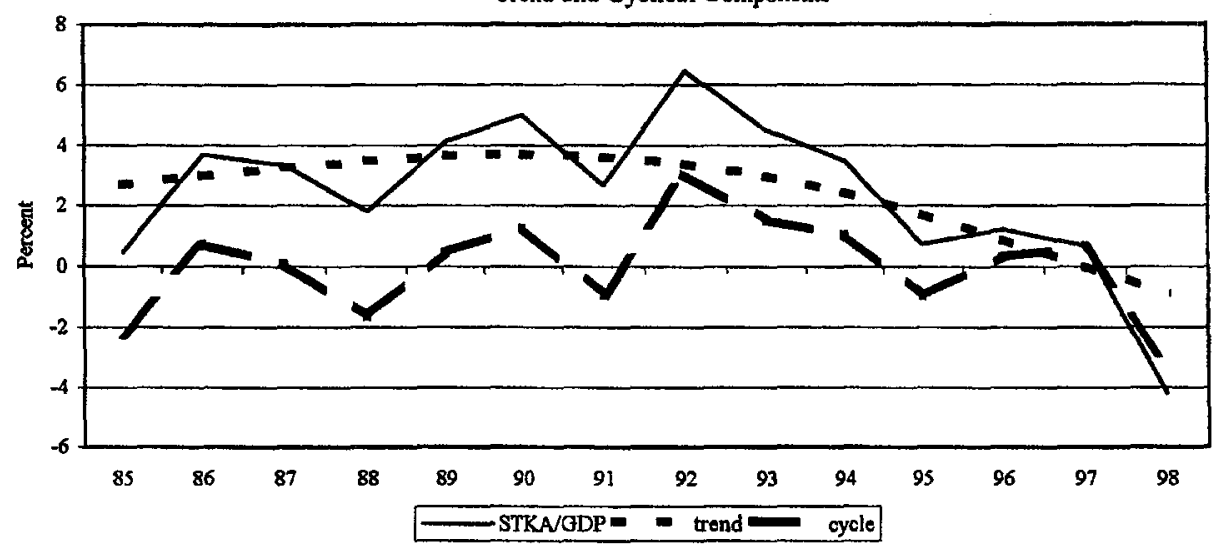

Figure 9b. Brazil: Short-term Capital Flow Ratio to GDP:

Trend and Cyclical Components

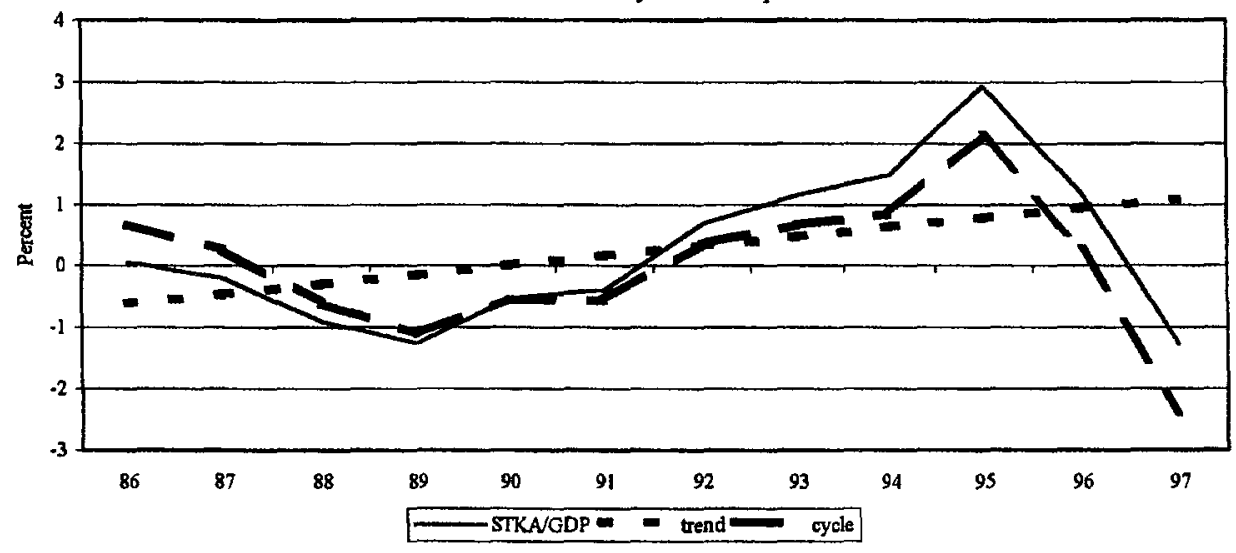

Fbure 9c. Mexico: Short-term Capital Flow Ratio to GDP:

Trend and Cyclical Components

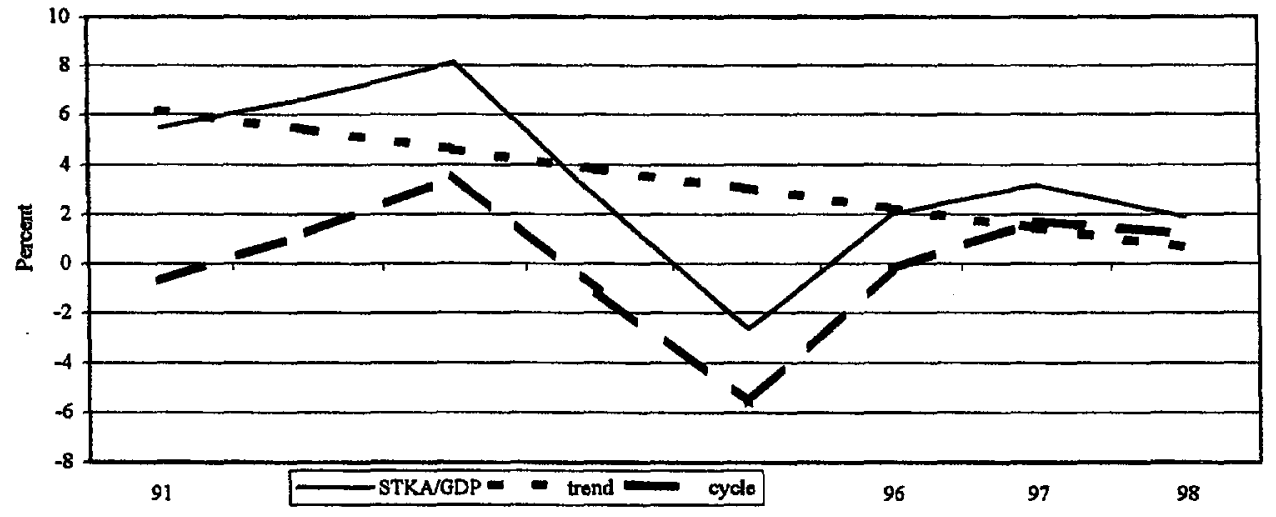

Sources: Central Bank of Chile; Central Bank of Brazil; Central Bank of Mexico; and Fund staff estimates. 


\section{Endogeneity of Regressors and Cointegration}

The endogeneity of some regressors and the possible presence of cointegration are problems often found in the reviewed literature. Given the importance of those issues for assessing the effectiveness of the URR, let us discuss them here in more detail. Assume the following cointegrated system of equations:

$$
\begin{gathered}
Y_{t}=\alpha X_{t}+\beta \Delta X_{t}+u_{t} \\
X_{t}=\gamma \Delta Y_{t-1}+\delta\left(Y_{t-1}-\alpha X_{t-1}\right)+v_{t}
\end{gathered}
$$

where, for instance, $\mathrm{Y}$ represents the domestic real interest rate and $\mathrm{X}$ represents the real exchange rate. In an equation used to test, say, the impact of the URR on domestic real interest rates, there are usually other right-hand side variables such as the URR and the foreign real interest rate. They are excluded here for simplicity.

If in the system (1)-(2) $\beta=\gamma=\delta=0$ or if $\delta=0$, using ordinary least squares to estimate equation (1) will give the best unbiased estimate of $\alpha$ and the distribution of the parameters will be normal. If instead $\beta=\gamma=0$, using ordinary least squares to estimate either equation (1) or (2) will be inappropriate and the distribution of parameters will be nonnormal. A systems technique will be necessary because $\mathrm{X}$ (i.e., the real exchange rate in our example) is a predetermined variable.

The second problem often found is made clear when $\delta \neq 0$. In that case, there is co-integration among the variables $\mathrm{Y}$ and $\mathrm{X} ; \mathrm{Y}$ and $\mathrm{X}$ have an error-correction representation. The use of instrumental variables in Equations 1 and 2, or the estimation of the system in first differences is, therefore, inappropriate. The omission of the expression $\left(\mathrm{Y}_{\mathrm{t}-1}-\alpha \mathrm{X}_{\mathrm{t}-1}\right)$ in Equation 2 entails a misspecification error. Parameter estimates will be biased and inconsistent. 
Annex Table 1. Summary of Rules onTransactions in the Different Foreign Exchange Markets

\begin{tabular}{|c|c|c|c|}
\hline A - Formal market & B - Informal Market & $\mathbf{C}$ & D \\
\hline $\begin{array}{l}\text { Current account } \\
\text {-all trade payments } \\
\text {-transfer of profits with CBC } \\
\text { approval } \\
\text { Capital account } \\
\text { Outflows related to: } \\
\text {-amortization of loans with } \\
\text { CBC approval } \\
\text {-capital repatriation with } \\
\text { CBC approval } \\
\text {-export advances and } \\
\text { supplier credits } \\
\text {-outward foreign direct } \\
\text { investment (FDI) with CBC } \\
\text { approval } \\
\text {-purchase of bonds abroad } \\
\text {-financial credits to non- } \\
\text { residents } \\
\text { Inflows related to: } \\
\text {-purchase of bonds and debt } \\
\text { securities by non-residents } \\
\text {-purchase by non-residents } \\
\text { of MM instruments } \\
\text {-purchase of securities--- } \\
\text { ADR sales } \\
\text {-issues of bonds and equity } \\
\text { abroad } \\
\text {-commercial credits from } \\
\text { abroad } \\
\text {-financial credits from } \\
\text { abroad } \\
\text {-FDI }\end{array}$ & $\begin{array}{l}\text { Capital account } \\
\text { Outflows by non-financial } \\
\text { agents of: } \\
\text {-purchase of fixed income } \\
\text { assets and deposits abroad } \\
\text {-purchase of MM } \\
\text { instruments abroad } \\
\text {-purchase of collective } \\
\text { securities abroad } \\
\text {-purchase of derivatives } \\
\text { abroad } \\
\text {-commercial credits to non- } \\
\text { residents } \\
\text { Other outflows: } \\
\text {-outward FDI by informing } \\
\text { the CBC } \\
\text {-purchase of real estate } \\
\text { abroad } \\
\text {-settlement of debts abroad } \\
\text { by immigrants }\end{array}$ & $\begin{array}{l}\text { Capital account } \\
\text { Investment of Chilean } \\
\text { banks abroad - } \\
\text { currency to be } \\
\text { obtained from the } \\
\text { formal market }\end{array}$ & $\begin{array}{l}\text { Capital account } \\
\text { Flows related to } \\
\text { exporters sales abroad, } \\
\text { if the money is kept } \\
\text { abroad }\end{array}$ \\
\hline
\end{tabular}

Note: If Central Bank of Chile (CBC) is not informed of outflows of capital, repatriation of capital subject to all rules governing capital inflows. All capital account transactions are regulated by Capitulo XII of Exchange Regulations. 
Table 1. Chile: Aggregate Supply and Demand

\begin{tabular}{|c|c|c|c|c|c|c|c|}
\hline & & & & & & Pan & \\
\hline & 1993 & 1994 & 1995 & 1996 & 1997 & 1997 & 1998 \\
\hline & I. 2 & current & $\begin{array}{l}\text { Change } \\
\text { s) }\end{array}$ & & & & \\
\hline Aggregate supply & 19.0 & 17.2 & 21.6 & 11.6 & 12.4 & 14.2 & 12.5 \\
\hline Gross domestio product & 18.4 & 19.0 & 20.9 & 10.3 & 13.3 & 12.7 & 11.1 \\
\hline Imports $2 /$ & 21.0 & 11.2 & 24.1 & 16.2 & 9.4 & 19.3 & 17.0 \\
\hline Domestic expenditure & 22.9 & 14.7 & 20.3 & 14.7 & 13.6 & 14.1 & 14.4 \\
\hline Private sector & 22.6 & 15.0 & 19.3 & 13.7 & 13.9 & $\ldots$ & $\ldots$ \\
\hline Consumption & 19.7 & 16.7 & 17.1 & 15.1 & 13.7 & $\ldots$ & $\ldots$ \\
\hline Investment & 33.2 & 9.5 & 27.2 & 9.3 & 14.8 & $: \quad \ldots$ & $\ldots$ \\
\hline Public sector & 23.5 & 18.1 & 16.9 & 22.0 & 12.1 & $\ldots$ & $\ldots$ \\
\hline Consumption $3 /$ & 22.8 & 18.0 & 19.5 & 14.3 & 10.9 & $\ldots$ & $\ldots$ \\
\hline Investment & 25.0 & 18.4 & 11.3 & 39.7 & 14.3 & $\cdots$ & \\
\hline Change in inventories 4 & 0.5 & -0.6 & 1.5 & 0.1 & 0.2 & 0.2 & -0.1 \\
\hline Exports 21 & 6.2 & 26.8 & 26.1 & 1.7 & 8.0 & 15.5 & 13.2 \\
\hline Memorandum items: & & & & & & & \\
\hline GNP at market prices & 19.3 & 17.6 & 21.9 & 10.1 & 14.0 & & \\
\hline GDP deflator & 10.6 & 12.6 & 9.3 & 2.7 & 5.8 & 6.1 & 5.3 \\
\hline & & nstant 19 & ices) & & & & \\
\hline Aggregate supply & 9.0 & 7.0 & 14.9 & 8.4 & 9.6 & 8.2 & 7.4 \\
\hline Gross domestic product & 7.0 & 5.7 & 10.6 & 7.4 & 7.1 & 6.2 & 5.4 \\
\hline Imports 2/ & 14.2 & 10.1 & 25.0 & 10.7 & 14.8 & 12.4 & 11.1 \\
\hline Domestic expenditure & 10.8 & 5.5 & 16.2 & 7.9 & 9.5 & 8.0 & 7.3 \\
\hline Private sector & 10.2 & 7.3 & 13.9 & 7.6 & 9.7 & $\ldots$ & $\ldots$ \\
\hline Consumption & 7.4 & 8.2 & 9.8 & 8.8 & 8.4 & $\ldots$ & $\ldots$ \\
\hline Investment & 19.4 & 4.6 & 26.7 & 4.4 & 13.3 & $\ldots$ & ... \\
\hline Public sector & 7.0 & 6.0 & 6.7 & 15.3 & 7.8 & $\ldots$ & $\ldots$ \\
\hline Consumption 3/ & 4.3 & 1.9 & 4.2 & 3.1 & 3.3 & $\ldots$ & $\ldots$ \\
\hline Investment & 12.1 & 13.1 & 10.8 & 33.4 & 12.8 & $\ldots$ & \\
\hline Change in inventories $4 /$ & 1.3 & -1.4 & 3.5 & -0.2 & 0.4 & 0.0 & -1.3 \\
\hline Exports 2/ & 3.5 & 11.6 & 11.0 & 10.0 & 9.9 & 8.9 & 7.5 \\
\hline Memorandum items: & & & & & & & \\
\hline GNP at market prices & 7.9 & 2.9 & 10.8 & 7.5 & 7.2 & $\ldots$ & ... \\
\hline GNP adjusted for terms of trade effects & 6.4 & 7.9 & 16.9 & 3.0 & 9.0 & $\cdots$ & $\cdots$ \\
\hline & II. & ent of $N$ & al GDP & & & & \\
\hline Aggregate supply & 129.9 & 128.0 & 128.7 & 130.3 & 129.2 & 131.7 & 133.4 \\
\hline Domestic expenditure & 102.4 & 98.7 & 98.2 & 102.1 & 102.4 & 102.4 & 105.4 \\
\hline Consumption & 75.9 & 74.6 & 72.4 & 75.5 & 75.5 & 75.4 & 78.0 \\
\hline Private sector & 65.9 & 64.6 & 62.6 & 65.3 & 65.5 & $\ldots$ & $\ldots$ \\
\hline General government & 10.0 & 9.9 & 9.8 & 10.2 & 10.0 & & \\
\hline Fixed capital formation & 24.9 & 23.3 & 23.9 & 24.8 & 25.2 & 25.2 & 26.0 \\
\hline Private sector & 20.3 & 18.6 & 19.6 & 19.4 & 19.7 & $\ldots$ & $\ldots$ \\
\hline Public sector & 4.7 & 4.6 & 4.3 & 5.4 & 5.5 & 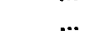 & \\
\hline Change in inventories & 1.6 & 0.8 & 1.9 & 1.8 & 1.7 & 1.8 & 1.5 \\
\hline Exports 2/ & 27.5 & 29.3 & 30.5 & 28.2 & 26.9 & 29.5 & 30.1 \\
\hline Imports $2 /$ & 29.9 & 28.0 & 28.7 & 30.3 & 29.2 & 31.7 & 33.4 \\
\hline External resource gap (-) & -2.4 & 1.3 & 1.8 & -2.1 & -2.4 & -2.2 & -3.3 \\
\hline
\end{tabular}

Sources: Central Bank of Chile; and Fund staff estimates.

1/ Nominal quarterly figures are Fund staff estimates.

2/ Goods and nonfactor services.

$3 /$ General government.

4/ Weighted by the contribution to domestic expenditure in the previous year. 
Table 2. Chile: Savings and Investment

(As percent of nominal GDP)

\begin{tabular}{|c|c|c|c|c|c|c|c|}
\hline & \multirow[b]{2}{*}{1993} & \multirow[b]{2}{*}{1994} & \multirow[b]{2}{*}{1995} & \multirow[b]{2}{*}{1996} & \multirow[b]{2}{*}{1997} & \multicolumn{2}{|c|}{$\begin{array}{l}\text { Prel. } \\
\text { Jan.Sep.1/ }\end{array}$} \\
\hline & & & & & & 1997 & 1998 \\
\hline Gross domestic investment & 26.5 & 24.1 & 25.8 & 26.6 & 26.9 & 27.0 & 27.4 \\
\hline Extemal savings & 5.7 & 3.1 & 2.1 & 5.4 & 5.3 & 3.5 & 3.8 \\
\hline Gross national savings & 20.8 & 21.0 & 23.6 & 21.2 & 21.6 & 23.5 & 23.7 \\
\hline Private investment $2 /$ & 21.8 & 19.5 & 21.5 & 21.2 & 21.4 & $\ldots$ & $-\ldots$ \\
\hline Private savings & 15.6 & 15.8 & 16.6 & 14.7 & 16.3 & $\ldots$ & $\ldots$ \\
\hline Net external financing & 8.6 & 9.8 & 7.1 & 9.5 & 9.7 & $\ldots$ & $\ldots$ \\
\hline \multicolumn{8}{|l|}{ Net resource transfer } \\
\hline from public sector 3 / & -2.4 & -6.2 & -2.2 & -3.0 & -4.5 & $\cdots$ & $\ldots$ \\
\hline Public investment & 4.7 & 4.6 & 4.3 & 5.4 & 5.5 & $\ldots$ & $\ldots$ \\
\hline Public savings 4 / & 5.1 & 5.1 & 7.1 & 6.5 & 5.3 & $\cdots$ & $\ldots$ \\
\hline Net external financing $5 /$ & -2.9 & -6.7 & -5.0 & -4.1 & -4.4 & $\ldots$ & $\ldots$ \\
\hline Of which: accumulation of reserves & -1.7 & -7.3 & -2.1 & -1.0 & -3.1 & $\ldots$ & $\ldots$ \\
\hline \multicolumn{8}{|l|}{ Net resource transfer } \\
\hline from private sector & 2.4 & 6.2 & 2.2 & 3.0 & 4.5 & $\cdots$ & $\ldots$ \\
\hline \multicolumn{8}{|l|}{ Memorandum items: } \\
\hline Gross domestic savings & 24.1 & 25.4 & 27.6 & 24.5 & 24.5 & 24.6 & 22.0 \\
\hline Net transfers from abroad & 0.7 & 0.7 & 0.5 & 0.7 & 0.7 & 0.5 & 0.1 \\
\hline
\end{tabular}

Sources: Central Bank of Chile; and Fund staff estimates.

1/ Nominal quarterly figures are Fund staff estimates.

2/ Includes changes in stocks.

3/ Defined as the excess of public sector savings and net external borrowing over publio sector fixed capital formation.

4/ Includes the nonfinancial public sector and the central bank quasi-fiscal deficit.

$5 /$ Net of changes in the net foreign assets of the central bank. 
Table 3. Chile: Sectoral Origin of GDP

(At constant 1986 market prices)

\begin{tabular}{|c|c|c|c|c|c|c|c|}
\hline & \multirow[b]{3}{*}{1993} & \multirow[b]{3}{*}{1994} & \multirow[b]{3}{*}{1995} & \multirow[b]{3}{*}{1996} & \multirow[b]{3}{*}{1997} & \multirow{2}{*}{\multicolumn{2}{|c|}{$\frac{\text { Prel. }}{\text { Jan.-Sep. 1/ }}$}} \\
\hline & & & & & & & \\
\hline & & & & & & 1997 & 1998 \\
\hline \multicolumn{8}{|c|}{ (Billions of Chilean pesos) } \\
\hline GDP at masket prices & $5,815.6$ & $6,147.6$ & $6,801.0$ & $7,223.6$ & $7,817.7$ & $5,785.52$ & $6,100.72$ \\
\hline Agriculture and forestry & 416.6 & 441.5 & 464.3 & 476.5 & 466.6 & 383.46 & 397.52 \\
\hline Fishing & 74.2 & 86.3 & 100.0 & 109.6 & 118.3 & 90.23 & 91.33 \\
\hline Mining & 443.3 & 482.8 & 527.8 & 596.2 & 644.3 & 477.95 & $4 \overline{88.28}$ \\
\hline Manufacturing & 987.1 & $1,027.4$ & $1,104.8$ & $1,143.3$ & $1,194.0$ & 885.28 & 887.38 \\
\hline Electricity, gas, and water & 146.0 & 155.1 & 166.9 & 169.0 & 185.0 & 133.35 & 145.43 \\
\hline Construction & 327.5 & 324.0 & 356.2 & 388.4 & 414.8 & 301.61 & 309.54 \\
\hline Commerce & 944.2 & 992.6 & $1,133.1$ & $1,239.3$ & $1,340.8$ & 988.28 & $1,064.64$ \\
\hline Transport; storage, and communioations & 428.9 & 452.0 & 518.3 & 572.9 & 646.7 & 472.57 & 532.40 \\
\hline Finanoial services & 778.2 & 833.6 & 915.1 & 981.2 & $1,054.0$ & 778.06 & 815.71 \\
\hline Other services $1 /$ & $1,269.6$ & $1,352.4$ & $1,514.5$ & $1,547.3$ & $1,753.2$ & $1,274.72$ & $1,368.49$ \\
\hline \multicolumn{8}{|c|}{ (Annual percentage change) } \\
\hline GDP at market prices & 7.0 & 5.7 & 10.6 & 6.2 & 8.2 & 6.19 & 5.45 \\
\hline Agriculture and forestry & 2.7 & 6.0 & 5.2 & 2.6 & -2.1 & -2.71 & 3.67 \\
\hline Fishing & 5.6 & 16.3 & 15.9 & 9.6 & 7.9 & 6.82 & 1.21 \\
\hline Mining & -0.2 & 8.9 & 9.3 & 13.0 & 8.1 & 9.03 & 2.16 \\
\hline Manufacturing & 7.3 & 4.1 & 7.5 & 3.5 & 4.4 & 3.83 & 0.24 \\
\hline Electricity, gas, and water & 4.8 & 6.2 & 7.6 & 1.2 & 9.5 & 4.02 & 9.07 \\
\hline Construction & 23.5 & -1.1 & 9.9 & 9.0 & 6.8 & 6.55 & 2.63 \\
\hline Commerce & 7.3 & 5.1 & 14.2 & 9.4 & 8.2 & 7.03 & 7.73 \\
\hline Transport, storage, and communications & 5.8 & 5.4 & 14.7 & 10.5 & 12.9 & 11.92 & 12.66 \\
\hline Financial services & 6.9 & 7.1 & 9.8 & 7.2 & 7.4 & 6.86 & 4.84 \\
\hline Other services $1 /$ & 7.8 & 6.5 & 12.0 & 2.2 & 13.3 & 14.27 & 7.36 \\
\hline \multicolumn{8}{|c|}{ (As percent of total) } \\
\hline GDP at maket prices & 100.0 & 100.0 & 100.0 & 100.0 & 100.0 & 100.00 & 100.00 \\
\hline Agriculture and forestry & 7.2 & 7.2 & 6.8 & 6.6 & 6.0 & 6.63 & 6.52 \\
\hline Fishing & 1.3 & 1.4 & 1.5 & 1.5 & 1.5 & 1.56 & 1.50 \\
\hline Mining & 7.6 & 7.9 & 7.8 & 8.3 & 8.2 & 8.26 & 8.00 \\
\hline Manufacturing & 17.0 & 16.7 & 16.2 & 15.8 & 15.3 & 15.30 & 14.55 \\
\hline Electrioity, gas, and water & 2.5 & 2.5 & 2.5 & 2.3 & 2.4 & 2.30 & 2.38 \\
\hline Construction & 5.6 & 5.3 & 5.2 & 5.4 & 5.3 & 5.21 & 5.07 \\
\hline Commerce & 16.2 & 16.1 & 16.7 & 17.2 & 17.2 & 17.08 & 17.45 \\
\hline Transport, storage, and communications & 7.4 & 7.4 & 7.6 & 7.9 & 8.3 & 8.17 & 8.73 \\
\hline Financial services & 13.4 & 13.6 & 13.5 & 13.6 & 13.5 & 13.45 & 13.37 \\
\hline Other services $1 /$ & 21.8 & 22.0 & 22.3 & 21.4 & 22.4 & 22.03 & 22.43 \\
\hline
\end{tabular}

Sources: Central Bank of Chile; and Fund staff estimates.

1/ Includes imputed banking charges, import duties, and value-added tax on imports. 
Table 4. Chile: National Accounts at Current Prices

\begin{tabular}{|c|c|c|c|c|c|c|c|}
\hline & \multirow[b]{3}{*}{1993} & \multirow[b]{3}{*}{1994} & \multirow[b]{3}{*}{1995} & \multirow[b]{3}{*}{1996} & \multirow[b]{3}{*}{1997} & \multirow{2}{*}{\multicolumn{2}{|c|}{$\frac{\text { Prel. }}{\text { Jan.-Sep. 1/ }}$}} \\
\hline & & & & & & & \\
\hline & & & & & & 1997 & 1998 \\
\hline Consumption expenditure & $13,650.3$ & $15,957.6$ & $18,730.5$ & $21,532.2$ & $24,395.8$ & $17,934.1$ & $20,608.2$ \\
\hline General government & $1,803.5$ & $2,128.5$ & $2,543.4$ & $2,906.3$ & $3,223.9$ & $\ldots$ & $\ldots$ \\
\hline Private sector & $11,846.7$ & $13,829.1$ & $16,187.1$ & $18,626.0$ & $21,171.9$ & $\ldots$ & $\cdots$ \\
\hline Gross domestic investment & $4,764.1$ & $5,155.7$ & $6,673.8$ & $7,598.3$ & $8,690.5$ & $6,418.4$ & $7,252.2$ \\
\hline Fixed capital formation & $4,479.5$ & $4,980.3$ & $6,177.1$ & $7,088.1$ & $8,129.1$ & $5,997.6$ & $6,862.4$ \\
\hline Public sector & 838.4 & 992.7 & $1,104.6$ & $1,542.8$ & $1,763.3$ & $\ldots$ & $\ldots$ \\
\hline Private sector & $3,641.2$ & $3,987.7$ & $5,072.5$ & $5,545.2$ & $6,365.8$ & $\ldots$ & $\ldots$ \\
\hline Change in stocks & 284.5 & 175.4 & 496.7 & 510.2 & 561.3 & 420.8 & 389.8 \\
\hline Domestic expenditure & $18,414.3$ & $21,113.3$ & $25,404.3$ & $29,130.5$ & $33,086.3$ & $24,352.5$ & $27,860.4$ \\
\hline External sector $2 /$ & -439.4 & 281.9 & 471.4 & -594.3 & -764.9 & -526.2 & -880.0 \\
\hline Exports & $4,943.1$ & $6,269.5$ & $7,904.9$ & $8,041.2$ & $8,686.4$ & $7,014.4$ & $7,942.0$ \\
\hline Imports & $-5,382.6$ & $-5,987.6$ & $-7,433.5$ & $-8,635.5$ & $-9,451.2$ & $-7,540.5$ & $-8,822.0$ \\
\hline GDP at market prices & $17,974.9$ & $21,395.2$ & $25,875.7$ & $28,536.2$ & $32,321.4$ & $23,790.3$ & $26,424.0$ \\
\hline Less: Net factor payments abroad & -689.7 & $-1,072.3$ & $-1,106.4$ & $-1,268.5$ & $-1,242.5$ & $\cdots$ & $\cdots$ \\
\hline GNP at market prices & $17,285.2$ & $20,322.9$ & $24,769.3$ & $27,267.7$ & $31,078.9$ & $\cdots$ & ... \\
\hline Less: Indirect taxes net of subsidies & $-2,702.6$ & $-2,986.0$ & $-3,493.2$ & $-3,852.4$ & $-4,363.4$ & $\cdots$ & $\cdots$ \\
\hline GNP at factor cost & $14,582.6$ & $17,336.9$ & $21,276.1$ & $23,415.3$ & $26,715.5$ & $\cdots$ & $\ldots$ \\
\hline \multicolumn{8}{|l|}{ Less: Provision for consumption } \\
\hline of fixed capital & $-1,565.8$ & $-1,832.2$ & $-2,199.4$ & $-2,425.6$ & $-2,747.3$ & $\cdots$ & $\cdots$ \\
\hline NNP at factor cost $=$ national income & $13,016.8$ & $15,504.7$ & $19,076.7$ & $20,989.7$ & $23,968.2$ & $\ldots$ & $\cdots$ \\
\hline
\end{tabular}

Sources: Central Bank of Chile; and Fund staff estimates.

1/ Nominal quarterly figures are Fund staff estimates.

2/ Goods and nonfactor services. 
Table 5. Chile: National Accounts at Constant Prices

\begin{tabular}{|c|c|c|c|c|c|c|c|}
\hline & \multirow[b]{3}{*}{1993} & \multirow[b]{3}{*}{1994} & \multirow[b]{3}{*}{1995} & \multirow[b]{3}{*}{1996} & \multirow[b]{3}{*}{1997} & \multirow{2}{*}{\multicolumn{2}{|c|}{$\begin{array}{l}\text { Prel. } \\
\text { Jan.-Sep. 1/ }\end{array}$}} \\
\hline & & & & & & & \\
\hline & & & & & & 1997 & 1998 \\
\hline Consumption expenditure & $4,367.0$ & $4,691.8$ & $5,122.5$ & $5,539.6$ & $5,978.6$ & $4,382.4$ & $4,783.1$ \\
\hline General government & 518.2 & 528.2 & 550.3 & 567.1 & 586.0 & $\ldots$ & $\ldots$ \\
\hline Private sector & $3,848.8$ & $4,163.5$ & $4,572.3$ & $4,972.5$ & $5,392.6$ & $\ldots$ & $\cdots$ \\
\hline Gross domestic investment & $1,811.1$ & $1,825.1$ & $2,449.4$ & $2,633.3$ & $2,970.2$ & $2,124.5$ & $2,202.0$ \\
\hline Fixed capital formation & $1,584.6$ & $1,682.7$ & $2,078.1$ & $2,278.1$ & $2,578.7$ & $1,830.9$ & $1,989.8$ \\
\hline Public sector & 296.6 & 335.4 & 371.6 & 495.9 & 559.4 & $\ldots$ & $\ldots$ \\
\hline Private sector & $1,288.1$ & $1,347.3$ & $1,706.5$ & $1,782.3$ & $2,019.4$ & $\ldots$ & $\ldots$ \\
\hline Changes in inventories & 226.5 & 142.5 & 371.4 & 355.2 & 391.5 & 293.6 & 212.3 \\
\hline Domestic expenditure & $6,178.1$ & $6,516.9$ & $7,572.0$ & $8,172.9$ & $8,948.9$ & $6,506.9$ & $6,985.1$ \\
\hline External sector $2 /$ & -362.5 & -369.3 & -771.0 & -871.0 & $-1,131.2$ & -721.4 & -884.4 \\
\hline Exports & $1,980.9$ & $2,211.2$ & $2,454.1$ & $2,700.3$ & $2,968.8$ & $2,240.4$ & $2,407.5$ \\
\hline Imports & $-2,343.4$ & $-2,580.5$ & $-3,225.1$ & $-3,571.2$ & $-4,100.0$ & $-2,961.8$ & $-3,291.9$ \\
\hline GDP at market prices & $5,815.6$ & $6,147.6$ & $6,801.0$ & $7,302.0$ & $7,817.7$ & $5,785.5$ & $6,100.7$ \\
\hline Less: Net factor payments abroad & -307.3 & -480.7 & -522.8 & -550.8 & -582.2 & $\ldots$ & $\ldots$ \\
\hline GNP at market prices & $5,508.4$ & $5,666.9$ & $6,278.1$ & $6,751.2$ & $7,235.4$ & $\ldots$ & $\ldots$ \\
\hline Less: Indirect taxes net of subsidies & -822.6 & -797.7 & -918.1 & -985.8 & $-1,055.4$ & $\ldots$ & ... \\
\hline GNP at factor cost & $4,685.8$ & $4,869.2$ & $5,360.0$ & $5,765.4$ & $6,180.1$ & $\ldots$ & $\ldots$ \\
\hline \multicolumn{8}{|l|}{ Less: Provision for consumption } \\
\hline of fixed capital & -553.9 & -619.0 & -612.1 & -657.2 & -703.6 & $\ldots$ & $\ldots$ \\
\hline Plus: Terms of trade effect & 171.2 & 468.6 & 917.3 & 625.1 & 805.6 & $\cdots$ & $\ldots$ \\
\hline NNP at factor cost $=$ national income & $4,303.1$ & $4,718.8$ & $5,665.2$ & $5,733.4$ & $6,282.1$ & $\ldots$ & $\ldots$ \\
\hline
\end{tabular}

Sources: Central Bank of Chile; and Fund staff estimates.

1/ Nominal quarterly figures are Fund staff estimates.

2/ Goods and nonfactor services. 
Table 6. Chile: Indicators of the Mining Sector

\begin{tabular}{|c|c|c|c|c|c|c|c|}
\hline & \multirow[b]{3}{*}{1993} & \multirow[b]{3}{*}{1994} & \multirow[b]{3}{*}{1995} & \multirow[b]{3}{*}{1996} & \multicolumn{3}{|c|}{ Preliminary } \\
\hline & & & & & \multirow[b]{2}{*}{1997} & \multicolumn{2}{|c|}{ January-July } \\
\hline & & & & & & 1997 & 1998 \\
\hline \multicolumn{8}{|c|}{$($ Index, $1990=100)$} \\
\hline Total & 123.2 & 131.4 & 146.2 & 177.6 & 192.6 & 189.3 & 201.9 \\
\hline Metallic minerals & 127.3 & 137.3 & 153.9 & 189.8 & 205.0 & 201.3 & 215.5 \\
\hline Copper & 130.9 & 135.5 & 155.5 & 194.3 & 212.6 & 208.0 & 225.0 \\
\hline Molybdenum & 107.7 & 115.3 & 120.7 & 125.9 & 154.8 & 148.0 & 177.1 \\
\hline Lead & 30.6 & 41.5 & 46.8 & 97.2 & 71.8 & 69.9 & 49.3 \\
\hline Zinc & 117.8 & 120.0 & 137.0 & 141.7 & 136.6 & 135.7 & 92.7 \\
\hline Gold & 122.0 & 134.2 & 160.8 & 188.5 & 173.9 & 177.3 & 168.0 \\
\hline Silver & 150.5 & 146.5 & 158.5 & 172.6 & 166.2 & 167.3 & 153.8 \\
\hline Iron & 89.8 & 104.8 & 102.2 & 110.1 & 105.9 & 108.2 & 112.0 \\
\hline Manganese & 159.7 & 158.6 & 177.5 & 157.3 & 158.1 & 175.2 & 135.5 \\
\hline Nonmetallic minerals $1 /$ & 90.3 & 84.0 & 83.7 & 78.9 & 91.8 & 92.5 & 91.9 \\
\hline Limestone & 154.7 & 174.5 & 167.7 & 171.6 & 160.4 & 156.8 & 168.0 \\
\hline Coal & 57.6 & 55.5 & 48.5 & 50.2 & 50.2 & 57.5 & 6.0 \\
\hline Petroleum & 72.5 & 62.8 & 53.2 & 46.8 & 43.0 & 43.8 & 40.4 \\
\hline \multicolumn{8}{|c|}{ (Thousands of metric tons) } \\
\hline Copper & $2,055.4$ & $2,219.9$ & $2,488.1$ & $3,141.2$ & 3392.0 & 1939.6 & 2105.6 \\
\hline CODELCO & $1,139.4$ & $1,139.9$ & $1,164.7$ & $1,246.7$ & 1326.3 & 751.2 & 854.7 \\
\hline Private sector & 916.0 & $1,086.0$ & $1,323.4$ & $1,894.5$ & 2065.7 & 1188.4 & 1250.9 \\
\hline \multicolumn{8}{|l|}{ By product } \\
\hline Refined copper & $1,268.2$ & $1,277.4$ & $1,491.5$ & $1,748.2$ & 2116.6 & 1202.4 & 1318.9 \\
\hline Blister & 120.9 & 183.0 & 174.7 & 243.1 & 154.0 & 90.3 & 118.8 \\
\hline Other & 666.3 & 759.5 & 822.4 & $1,124.5$ & 1121.4 & 646.9 & 678.6 \\
\hline \multicolumn{8}{|c|}{ (Annual percentage changes) } \\
\hline Total & 4.0 & 6.7 & 11.3 & 21.5 & 8.4 & -1.7 & 6.7 \\
\hline Metallic minerals & 4.7 & 7.9 & 12.1 & 23.3 & 8.0 & -1.8 & 7.1 \\
\hline Copper & 7.0 & 3.5 & 14.8 & 25.0 & 9.4 & -2.2 & 8.2 \\
\hline Molybdenum & 0.5 & 7.1 & 4.7 & 4.3 & 23.0 & -4.4 & 19.7 \\
\hline Lead & 15.0 & 35.6 & 12.8 & 107.7 & -26.1 & -2.6 & -29.5 \\
\hline Zinc & -0.3 & 1.9 & 14.2 & 3.4 & -3.6 & -0.7 & -31.7 \\
\hline Gold & -0.7 & 10.0 & 19.8 & 17.2 & -7.7 & 1.9 & -5.2 \\
\hline Silver & -4.2 & -2.7 & 8.2 & 8.9 & -3.7 & 0.7 & -8.1 \\
\hline Iron & 2.5 & 16.7 & -2.5 & 7.7 & -3.8 & 2.2 & 3.4 \\
\hline Manganese & 27.1 & -0.7 & 11.9 & -11.4 & 0.5 & 10.8 & -22.7 \\
\hline Nonmetallic minerals $1 /$ & -0.6 & -7.0 & -0.4 & -5.7 & 16.3 & 0.7 & -0.6 \\
\hline Limestone & 9.7 & 12.8 & -3.9 & 2.3 & -6.5 & -2.2 & 7.1 \\
\hline Coal & -17.4 & -3.6 & -12.6 & 3.5 & 0.0 & 14.5 & -89.5 \\
\hline Petroleum & -4.4 & -13.4 & -15.3 & -12.0 & -8.1 & 2.0 & -7.9 \\
\hline
\end{tabular}

Source: National Bureau of Statistics, as reported in the Monthly Bulletin of the Central Bank of Chile.

1/Includes iodine and nitrate. 
Table 7. Chile: Indicators of the Manufacturing Sector

(Annual percentage changes)

\begin{tabular}{|c|c|c|c|c|c|c|}
\hline & \multirow[b]{3}{*}{1994} & \multirow[b]{3}{*}{1995} & \multirow[b]{3}{*}{1996} & \multicolumn{3}{|c|}{ Preliminary } \\
\hline & & & & \multirow[b]{2}{*}{1997} & \multicolumn{2}{|c|}{ January-July } \\
\hline & & & & & 1997 & 1998 \\
\hline \multicolumn{7}{|l|}{ Production } \\
\hline \multicolumn{7}{|l|}{ Consumer goods } \\
\hline Nondurables & 6.6 & 6.3 & 5.6 & -0.1 & $\ldots$ & 6.9 \\
\hline Durables & 7.3 & 7.4 & -1.7 & 0.3 & $\ldots$ & 8.0 \\
\hline Transport equipment & 1.8 & -2.2 & -0.6 & 20.9 & $\ldots$ & 1.0 \\
\hline Capital goods & 12.0 & 8.1 & 7.0 & 18.3 & $\ldots$ & 1.3 \\
\hline \multicolumn{7}{|l|}{ Intermediate goods } \\
\hline For industry & 1.2 & 4.5 & 3.1 & 6.0 & $\ldots$ & 5.2 \\
\hline For construction & -0.1 & 5.9 & 8.3 & 6.7 & $\ldots$ & 8.0 \\
\hline For mining & 9.6 & 15.7 & 10.4 & 8.8 & $\ldots$ & 3.8 \\
\hline For agriculture & 14.5 & -4.7 & -18.8 & -1.3 & $\ldots$ & -49.0 \\
\hline Packaging and accessories & 0.3 & 15.3 & 12.8 & 0.1 & $\ldots$ & 2.5 \\
\hline Energy, fuels, and lubricants & 8.5 & 7.4 & 1.0 & 4.1 & $\ldots$ & 4.3 \\
\hline Office furniture & 5.7 & 9.6 & 2.5 & 8.4 & $\ldots$ & 1.6 \\
\hline \multicolumn{7}{|l|}{ Sales } \\
\hline \multicolumn{7}{|l|}{ Consumer goods } \\
\hline Nondurables & 5.7 & 6.7 & 3.9 & 3.4 & & 5.6 \\
\hline Durables & 4.8 & 4.8 & 0.5 & -2.7 & & -4.2 \\
\hline Transport equipment & -2.5 & -2.3 & -2.7 & 30.4 & & 0.9 \\
\hline Capital goods & 6.8 & 14.5 & 4.1 & 24.9 & & 13.4 \\
\hline \multicolumn{7}{|l|}{ Intermediate goods } \\
\hline For industry & -3.2 & 2.9 & 4.9 & 9.0 & & 2.2 \\
\hline For construction & -0.1 & 6.8 & 9.9 & 5.7 & & 6.5 \\
\hline For mining & 6.4 & 17.4 & 8.8 & 8.2 & & 10.9 \\
\hline For agriculture & 12.1 & 8.0 & -22.6 & 5.0 & & -33.9 \\
\hline Packaging and accessories & 4.4 & 18.3 & 6.7 & -0.8 & & 7.6 \\
\hline Energy, fuels, and lubricants & 9.7 & 8.8 & 4.9 & 0.3 & & 4.6 \\
\hline Office furniture & 7.4 & 8.4 & 5.6 & 4.1 & & 2.6 \\
\hline
\end{tabular}

Source: Chilean Association of Manufacturers (SOFOFA). 
Table 8. Chile: Population, Labor Force, and Employment

\begin{tabular}{|c|c|c|c|c|c|c|c|}
\hline & \multirow[b]{3}{*}{1993} & \multirow[b]{3}{*}{1994} & \multirow[b]{3}{*}{1995} & \multirow[b]{3}{*}{1996} & \multicolumn{3}{|c|}{ Preliminary } \\
\hline & & & & & \multirow[b]{2}{*}{1997} & \multicolumn{2}{|c|}{ Jan.-Aug. } \\
\hline & & & & & & 1997 & 1998 \\
\hline \multicolumn{8}{|c|}{ (In thousands of persons) } \\
\hline Total population & $13,697.80$ & $13,917.00$ & $14,153.60$ & $14,392.80$ & $14,605.22$ & $14,571.63$ & $14,772.08$ \\
\hline Population 15 years and older & $9,668.70$ & $9,842.20$ & $10,012.10$ & $10,181.30$ & $10,363.49$ & $10,334.70$ & $10,506.54$ \\
\hline Labor force & $5,322.30$ & $\mathbf{5 , 4 5 8 . 8 0}$ & $5,497.08$ & $5,521.91$ & $5,618.36$ & $\mathbf{5 , 5 9 3 . 5 0}$ & $5,686.64$ \\
\hline Employed & $4,976.50$ & $5,033.70$ & $5,092.30$ & $5,164.00$ & $5,274.56$ & $5,251.03$ & $5,360.54$ \\
\hline $\begin{array}{l}\text { Unemployed } \\
\text { Layoffs }\end{array}$ & 345.80 & 425.10 & 405.20 & 357.91 & 343.80 & 342.47 & 326.10 \\
\hline \multicolumn{8}{|c|}{ (In percent) } \\
\hline \multicolumn{8}{|l|}{$\begin{array}{l}\text { Unemployed (as percentage } \\
\text { of the labor force) }\end{array}$} \\
\hline Total & 6.5 & 7.8 & 7.4 & 6.5 & 6.1 & 6.1 & 5.7 \\
\hline Metropolitan Santiago Region & 6.2 & 8.3 & 7.5 & 7.1 & 7.1 & 7.1 & 6.3 \\
\hline \multicolumn{8}{|l|}{ Participation rates } \\
\hline $\begin{array}{l}\text { Labor force as percentage of } \\
\text { total population }\end{array}$ & 38.9 & 39.2 & 38.8 & 38.4 & 38.5 & 38.4 & 38.5 \\
\hline \multicolumn{7}{|l|}{ Labor force as percentage of } & 54.1 \\
\hline \multicolumn{8}{|c|}{ (Annual change in percent) } \\
\hline Total population & 1.6 & 1.6 & 1.7 & 1.7 & 1.5 & -0.2 & 1.4 \\
\hline Labor force & 5.6 & 2.6 & 0.7 & 0.5 & 1.7 & -0.4 & 1.7 \\
\hline Employment & 5.8 & 1.1 & 1.2 & 1.4 & 2.1 & -0.4 & 2.1 \\
\hline Unemployment & 2.6 & 22.9 & -4.7 & -11.7 & -3.9 & -0.4 & -4.8 \\
\hline
\end{tabular}

Source: National Bureau of Statistics (INE). 
Table 9. Chile: Index of Nominal Wages

\begin{tabular}{|c|c|c|c|c|c|c|c|}
\hline & \multicolumn{2}{|c|}{ Apr.-Dec. } & \multicolumn{3}{|c|}{ Yearly averages } & \multicolumn{2}{|c|}{ Jan.-Aug. } \\
\hline & 1993 & 1994 & 1995 & 1996 & 1997 & 1997 & 1998 \\
\hline \multicolumn{8}{|c|}{ (Annual averages) } \\
\hline Overall & 106.3 & 125.1 & 140.4 & 156.3 & 169.9 & 168.1 & 181.5 \\
\hline Mining & 101.9 & 115.2 & 121.9 & 135.7 & 146.5 & 144.8 & 153.4 \\
\hline Manufacturing & 108.6 & 126.6 & 140.9 & 156.6 & 170.1 & 168.3 & 179.5 \\
\hline Electricity, gas, and water & 103.4 & 116.2 & 128.4 & 145.7 & 155.5 & 154.3 & 164.2 \\
\hline Construction & 107.3 & 122.8 & 138.2 & 148.0 & 150.3 & 148.9 & 157.5 \\
\hline Trade, restaurants, and hotels & 107.6 & 127.7 & 143.0 & 157.9 & 171.5 & 168.8 & 183.9 \\
\hline Transportation and communications & 102.6 & 127.5 & 145.9 & 157.6 & 171.8 & 169.6 & 185.2 \\
\hline Financial services and insurance & 102.5 & 118.8 & 129.4 & 142.1 & 152.8 & 151.1 & 164.0 \\
\hline Social services & 106.4 & 126.9 & 146.4 & 166.9 & 184.4 & 182.8 & 200.4 \\
\hline \multicolumn{8}{|c|}{ (Annual percentage changes) } \\
\hline Overall & $\cdots$ & 17.4 & 13.6 & $\mathbf{1 1 . 3}$ & 8.7 & 9.1 & 8.0 \\
\hline Mining & $\ldots$ & 13.1 & 7.3 & 11.3 & 7.9 & 8.4 & 5.9 \\
\hline Manufacturing & $\ldots$ & 16.4 & 12.6 & 11.1 & 8.6 & 9.4 & 6.6 \\
\hline Electricity, gas, and water & $\cdots$ & 13.2 & 12.0 & 13.5 & 6.7 & 7.3 & 6.5 \\
\hline Construction & $\cdots$ & 14.7 & 14.6 & 7.1 & 1.6 & 1.1 & 5.8 \\
\hline Trade, restaurants and hotels & $\cdots$ & 15.9 & 13.6 & 10.4 & 8.6 & 8.4 & 9.0 \\
\hline Transportation and communications & ... & 15.7 & 16.4 & 8.0 & 9.0 & 8.9 & 9.3 \\
\hline Financial services and insurance & $\ldots$ & 14.7 & 10.0 & 9.8 & 7.5 & 7.2 & 8.6 \\
\hline Social services & $\cdots$ & 19.4 & 16.5 & 14.0 & 10.5 & 11.1 & 9.6 \\
\hline \multicolumn{8}{|l|}{ Memorandum items } \\
\hline Consumer price inflation & & & & & & & \\
\hline (annual average) & 12.7 & 10.8 & 8.2 & 7.4 & 6.1 & 6.1 & 5.4 \\
\hline Minimum wage & 14.9 & 14.5 & 13.1 & 11.9 & 9.9 & 10.3 & 10.5 \\
\hline Real wages 3 / & $\ldots$ & 5.9 & 4.8 & 3.7 & 2.4 & 2.8 & 2.5 \\
\hline
\end{tabular}

Source: National Bureau of Statistics (INE). 
Table 10. Chile: Consumer Price Index

(Base: April 1989 = 100)

\begin{tabular}{|c|c|c|c|c|c|c|c|c|}
\hline & & \multirow{3}{*}{ All items } & \multirow{3}{*}{ Food } & \multirow{3}{*}{ Housing } & \multicolumn{3}{|c|}{ Transportation } & \multirow{3}{*}{$\begin{array}{l}\text { Core } \\
\text { Inflation } \\
\text { Index 1/ }\end{array}$} \\
\hline & & & & & Clothing & and & Miscellaneous & \\
\hline & & & & & \multicolumn{3}{|c|}{ Communication } & \\
\hline \multicolumn{9}{|c|}{ (Period averages, annual percentage change) } \\
\hline 1993 & & 12.7 & 10.9 & 13.8 & 10.5 & 10.3 & 18.5 & 13.4 \\
\hline 1994 & & 11.4 & 9.8 & 12.2 & 3.0 & 11.4 & 17.2 & 11.7 \\
\hline 1995 & & 8.2 & 8.3 & 7.6 & -1.2 & 10.2 & 10.6 & 7.5 \\
\hline 1996 & & 7.4 & 6.1 & 7.7 & -7.1 & 10.7 & 11.0 & 8.1 \\
\hline 1997 & & 6.1 & 7.1 & 5.9 & -4.7 & 4.9 & 8.5 & 5.5 \\
\hline \multicolumn{9}{|c|}{ (End of period, annual percentage change) } \\
\hline 1993 & March & 12.7 & 11.1 & 12.6 & 12.7 & 10.2 & 18.3 & 12.2 \\
\hline & June & 13.0 & 11.6 & 14.0 & 11.8 & 9.8 & 17.8 & 13.8 \\
\hline & September & 12.3 & 10.2 & 14.3 & 10.0 & 8.8 & 18.4 & 13.5 \\
\hline & December & 12.2 & 8.5 & 14.7 & 4.8 & 12.7 & 19.7 & 13.4 \\
\hline 1994 & March & 13.7 & 13.1 & 14.6 & 4.8 & 11.2 & 19.7 & 13.5 \\
\hline & June & 12.7 & 12.5 & 12.8 & 1.9 & 12.2 & 18.1 & 12.6 \\
\hline & September & 10.4 & 8.3 & 10.4 & 1.4 & 13.1 & 16.0 & 10.5 \\
\hline .. & December & 8.9 & 7.0 & 8.9 & 3.7 & 9.6 & 14.1 & 9.5 \\
\hline 19951 & March & 8.2 & 7.4 & 8.2 & 1.2 & 10.5 & 10.0 & 7.7 \\
\hline & June & 7.6 & 7.4 & 7.3 & -0.5 & 9.2 & 10.0 & 6.8 \\
\hline & September & 8.6 & 9.6 & 7.4 & -3.4 & 11.2 & 10.2 & 7.2 \\
\hline & December & 8.2 & 9.0 & 7.1 & -5.5 & 11.4 & 10.0 & 7.5 \\
\hline 1996 & March & 7.9 & 7.6 & 7.1 & -6.5 & 12.0 & 11.0 & 8.0 \\
\hline & June & 8.3 & 8.7 & 7.6 & -9.2 & 11.3 & 11.4 & 8.8 \\
\hline & September & 6.3 & 3.9 & 8.0 & -7.0 & 7.2 & 11.7 & 7.7 \\
\hline & December & 6.6 & 4.1 & 8.1 & -4.7 & 9.2 & 10.5 & 7.4 \\
\hline 1997 & March & 6.8 & 6.9 & 7.2 & 4.0 & 7.1 & 8.7 & 6.3 \\
\hline & June & 5.3 & 4.2 & 6.3 & -2.7 & 4.8 & 8.2 & 4.9 \\
\hline & September & 6.0 & 7.8 & 4.8 & -5.2 & 5.3 & 8.0 & 5.2 \\
\hline & December & 6.0 & 9.2 & 4.7 & -8.4 & 2.4 & 9.0 & 5.4 \\
\hline 1998 & March & 5.3 & 6.6 & 4.7 & -6.3 & 1.3 & 10.0 & 5.3 \\
\hline & June & 5.4 & 4.3 & 4.4 & -3.1 & 6.4 & 9.6 & 5.9 \\
\hline & September & 4.8 & 1.8 & 5.1 & -4.1 & 7.1 & 9.7 & 5.6 \\
\hline
\end{tabular}

Source: National Bureau of Statistics (INE).

1/Excluding the eleven most volatile food items. 
Table 11. Chile: Social Indicators

\begin{tabular}{|c|c|c|c|c|c|}
\hline & 1987 & 1990 & 1992 & 1994 & $\begin{array}{l}\text { Prel. } \\
1996 \\
\end{array}$ \\
\hline \multicolumn{6}{|l|}{ Incidence of poverty $1 /$} \\
\hline \multicolumn{6}{|l|}{ Indigent } \\
\hline Total & 17.4 & 12.9 & 8.8 & 7.6 & 5.8 \\
\hline Urban & $\ldots$ & 12.9 & 8.6 & 7.6 & 5.0 \\
\hline Rural & $\ldots$ & 17.8 & 10.0 & 10.3 & 9.4 \\
\hline \multicolumn{6}{|l|}{ Poor, but not indigent } \\
\hline Total & 27.7 & 25.7 & 23.8 & 19.9 & 17.4 \\
\hline Urban & $\ldots$ & 26.6 & 23.9 & 20.3 & 16.8 \\
\hline Rural & $\ldots$ & 25.0 & 23.8 & 21.5 & 21.2 \\
\hline \multicolumn{6}{|l|}{ Total poor } \\
\hline Total & 45.1 & 38.6 & 32.6 & 27.5 & 23.2 \\
\hline Urban & $\ldots$ & 39.5 & 32.5 & 27.9 & 21.8 \\
\hline Rural & $\ldots$ & 42.8 & 33.8 & 31.8 & 30.6 \\
\hline \multicolumn{6}{|l|}{ Income distribution $2 /$} \\
\hline First quintile & 4.3 & 4.4 & 4.6 & 4.3 & 4.1 \\
\hline Fifth quintile & 57.2 & 56.9 & 56.3 & 56.9 & 56.7 \\
\hline \multicolumn{6}{|l|}{ Ratio of income of fifth quintile to } \\
\hline \multicolumn{6}{|l|}{ Other indicators of social welfare } \\
\hline Illiteracy $3 /$ & 6.1 & 5.4 & 5.2 & 4.8 & $\ldots$ \\
\hline \multicolumn{6}{|l|}{ School enrollment 4 / } \\
\hline Elementary school (6-13 years of age) & 96.4 & 96.8 & 97.4 & 97.6 & 98.2 \\
\hline Secondary school (14-17 years of age) & 80.9 & 80.3 & 82.4 & 84.9 & 83.8 \\
\hline Post secondary (18-24 years of age) & $\ldots$ & 24.7 & 26.5 & 29.6 & 33.8 \\
\hline Life expectancy at birth 5 / & 71.7 & 72.0 & 74.3 & 74.6 & ... \\
\hline Infant mortality rate $6 /$ & 18.5 & 16.0 & 14.3 & 12.0 & ... \\
\hline
\end{tabular}

Source: Ministry of Cooperation and Planning (MIDEPLAN).

1/ Percent of population.

2/ Distribution of national income by quintiles of households.

$3 /$ Percent of population over 15 years of age.

4/ Percent of the age group enrolled.

$5 /$ Years.

6/ Per 1,000 live births. 
Table 12. Chile: Summary Operations of the Combined Public Sector

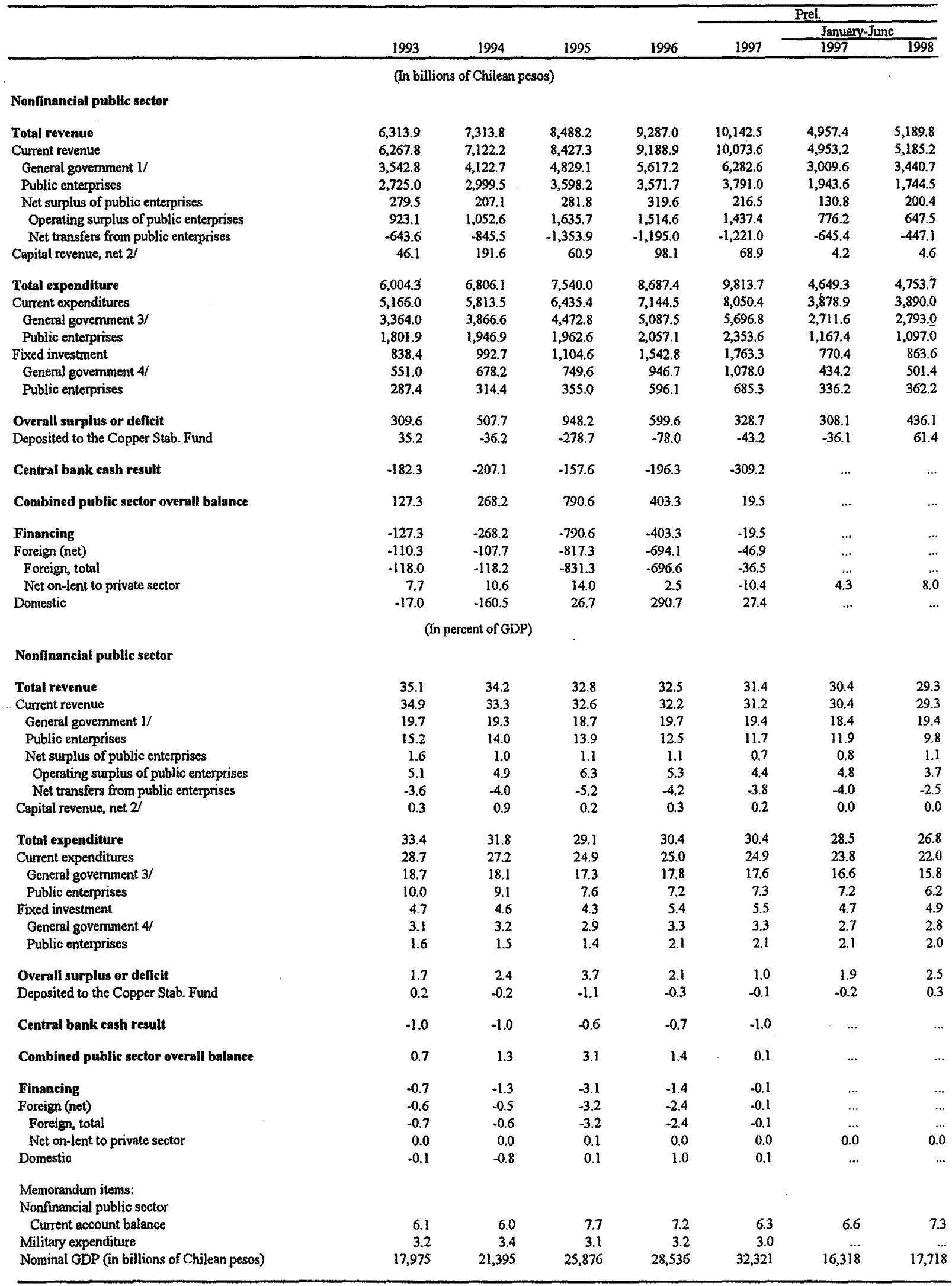

Sources: Ministry of Finance; Central Bank of Chile; and Fund staff estimates

1/ Excludes taxes paid and transfers made by the public enterprises.

$2 /$ Net of financial investment and expenditure related to sale of assets.

3/ Includes amount transferred directly by CODELCO for military purchases.

4/ Includes capital transfers to the private sector; net of cepital transfers to other public entitites. 
Table 13. Chile: Summary Operations of the General Government

\begin{tabular}{|c|c|c|c|c|c|c|c|}
\hline & \multirow[b]{3}{*}{1993} & \multirow[b]{3}{*}{1994} & \multirow[b]{3}{*}{1995} & \multirow[b]{3}{*}{1996} & \multicolumn{3}{|c|}{ Prel. } \\
\hline & & & & & \multirow[b]{2}{*}{$1997^{-}$} & \multicolumn{2}{|c|}{ January-June } \\
\hline & & & & & & 1997 & 1998 \\
\hline \multicolumn{8}{|c|}{ (In billions of Chilean pesos) } \\
\hline Total revenue & $4,339.9$ & $5,102.8$ & $6,377.2$ & $6,983.3$ & $7,694.4$ & $3,747.8$ & $3,984.1$ \\
\hline Current revenue & $4,186.4$ & $4,968.3$ & $6,183.0$ & $6,812.2$ & $7,503.5$ & $3,655.0$ & $3,887.8$ \\
\hline $\operatorname{Tax}$ & $3,668.5$ & $4,405.9$ & $5,455.7$ & $6,010.4$ & $6,565.4$ & $3,220.9$ & $3,400.5$ \\
\hline Nontax & 518.0 & 530.1 & 727.2 & 801.8 & 938.1 & 434.1 & 487.3 \\
\hline Capital revenue & 153.5 & 166.8 & 194.2 & 171.1 & 190.9 & 92.8 & 96.3 \\
\hline Total expenditure & $3,961.9$ & $4,615.1$ & $5,317.7$ & $6,142.8$ & $6,905.8^{i}$ & $3,209.7$ & $3,363.7$ \\
\hline Current expenditure & $3,364.0$ & $3,866.6$ & $4,472.8$ & $5,087.5$ & $5,696.8$ & $2,711.6$ & $2,793.0$ \\
\hline Wages & 713.3 & 854.1 & $1,000.3$ & $1,159.3$ & $1,325.1$ & 637.8 & 725.8 \\
\hline Pensions & $1,105.9$ & $1,282.5$ & $1,465.0$ & $1,698.3$ & $1,897.7$ & 916.0 & $1,036.6$ \\
\hline Interest & 239.8 & 217.4 & 198.9 & 171.7 & 143.4 & 74.1 & 73.0 \\
\hline Other & $1,305.0$ & $1,150.6$ & $1,808.7$ & $2,058.2$ & $2,330.6$ & $1,083.6$ & 957.6 \\
\hline Capital expenditure & 597.9 & 748.5 & 844.9 & $1,055.4$ & $1,209.0$ & 498.2 & 570.6 \\
\hline Overall surplus or deficit(-) & 378.0 & 487.7 & $1,059.4$ & 840.5 & 788.7 & 538.1 & 620.4 \\
\hline Current account & 822.4 & $1,069.3$ & $1,710.1$ & $1,724.7$ & $1,806.7$ & 943.4 & $1,094.8$ \\
\hline Capital account & -444.4 & -581.6 & -650.7 & -884.3 & $-1,018.0$ & -405.4 & -474.3 \\
\hline Financing & -378.0 & -487.7 & $-1,059.4$ & -840.5 & -788.7 & -538.1 & -620.4 \\
\hline Foreign, net & -165.8 & -99.7 & -606.2 & -281.9 & -184.2 & $\ldots$ & $\ldots$ \\
\hline Foreign, net total & -173.4 & -110.2 & -620.2 & -284.4 & -173.8 & $\ldots$ & $\ldots$ \\
\hline Net on-lent to private sector & 7.7 & 10.6 & 14.0 & 2.5 & -10.4 & 4.3 & 8.0 \\
\hline $\begin{array}{l}\text { Domestic } \\
\text { Of which: deposited in the Copper }\end{array}$ & -212.2 & -388.0 & -453.2 & -558.6 & -604.4 & $\ldots$ & $\ldots$ \\
\hline Stabilization Fund (deposit -) & 35.2 & -33.7 & -278.7 & -78.0 & -43.2 & -36.1 & 61.4 \\
\hline \multicolumn{8}{|c|}{ (In percent of GDP) } \\
\hline Total revenue & 24.1 & 23.9 & 24.6 & 24.5 & 23.8 & 23.0 & 22.5 \\
\hline Current revenue & 23.3 & 23.2 & 23.9 & 23.9 & 23.2 & 22.4 & 21.9 \\
\hline $\operatorname{Tax}$ & 20.4 & 20.6 & 21.1 & 21.1 & 20.3 & 19.7 & 19.2 \\
\hline Nontax & 2.9 & 2.5 & 2.8 & 2.8 & 2.9 & 2.7 & 2.8 \\
\hline Capital revenue & 0.9 & 0.8 & 0.8 & 0.6 & 0.6 & 0.6 & 0.5 \\
\hline Total expenditure & 22.0 & 21.6 & 20.6 & 21.5 & 21.4 & 19.7 & 19.0 \\
\hline Current expenditure & 18.7 & 18.1 & 17.3 & 17.8 & 17.6 & 16.6 & 15.8 \\
\hline Wages & 4.0 & 4.0 & 3.9 & 4.1 & 4.1 & 3.9 & 4.1 \\
\hline Pensions & 6.2 & 6.0 & 5.7 & 6.0 & 5.9 & 5.6 & 5.9 \\
\hline Interest & 1.3 & 1.0 & 0.8 & 0.6 & 0.4 & 0.5 & 0.4 \\
\hline Other & 7.3 & 5.4 & 7.0 & 7.2 & 7.2 & 6.6 & 5.4 \\
\hline Capital expenditure & 3.3 & 3.5 & 3.3 & 3.7 & 3.7 & 3.1 & 3.2 \\
\hline Overall surplus or deficit(-) & 2.1 & 2.3 & 4.1 & 2.9 & 2.4 & 3.3 & 3.5 \\
\hline Current account & 4.6 & 5.0 & 6.6 & 6.0 & 5.6 & 5.8 & 6.2 \\
\hline Capital account & -2.5 & -2.7 & -2.5 & -3.1 & -3.1 & -2.5 & -2.7 \\
\hline & & 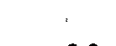 & & & & & \\
\hline Financing & -2.1 & -2.3 & -4.1 & -2.9 & -2.4 & -3.3 & -3.5 \\
\hline Foreign, net & -0.9 & -0.5 & -2.3 & -1.0 & -0.6 & $\ldots$ & $\ldots$ \\
\hline Foreign, net total & -1.0 & -0.5 & -2.4 & -1.0 & -0.5 & $\ldots$ & $\ldots$ \\
\hline Net on-lent to private sector & 0.0 & 0.0 & 0.1 & 0.0 & 0.0 & 0.0 & 0.0 \\
\hline $\begin{array}{l}\text { Domestic } \\
\text { Of which: deposited in the Copper }\end{array}$ & -1.2 & -1.8 & -1.8 & -2.0 & -1.9 & $\ldots$ & $\ldots$ \\
\hline Stabilization Fund (deposit -) & 0.2 & -0.2 & -1.1 & -0.3 & -0.1 & -0.2 & 0.3 \\
\hline
\end{tabular}

Sources: Ministry of Finance; and Fund staff estimates. 
Table 14. Chile: General Government Revenue

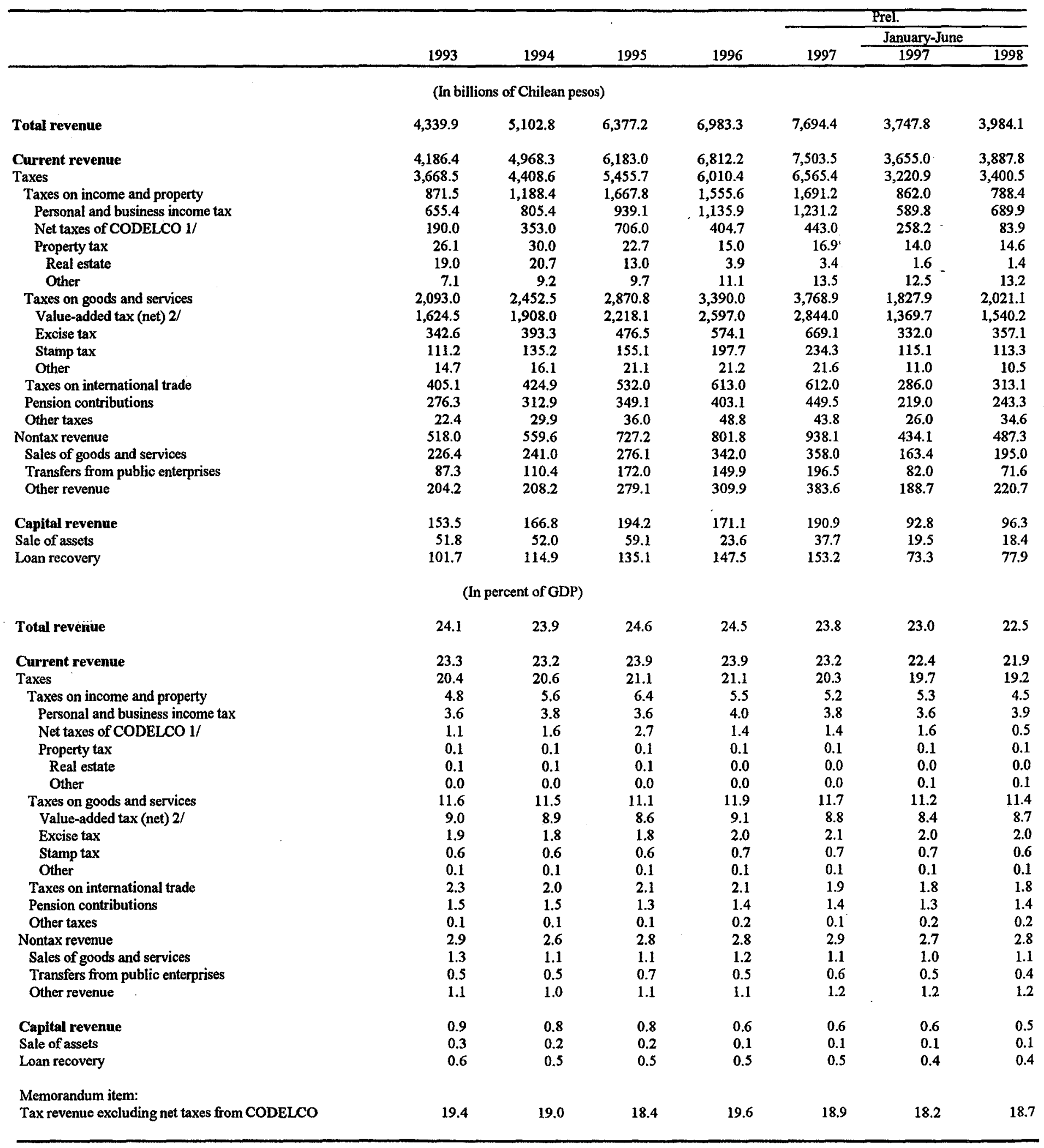

Sources: Ministry of Finance; and Fund staff estimates.

1/ Including deposits by CODELCO for military purchases under Law 13,196.

$2 /$ Net of rebates. 
Table 15. Chile: General Government Expenditure

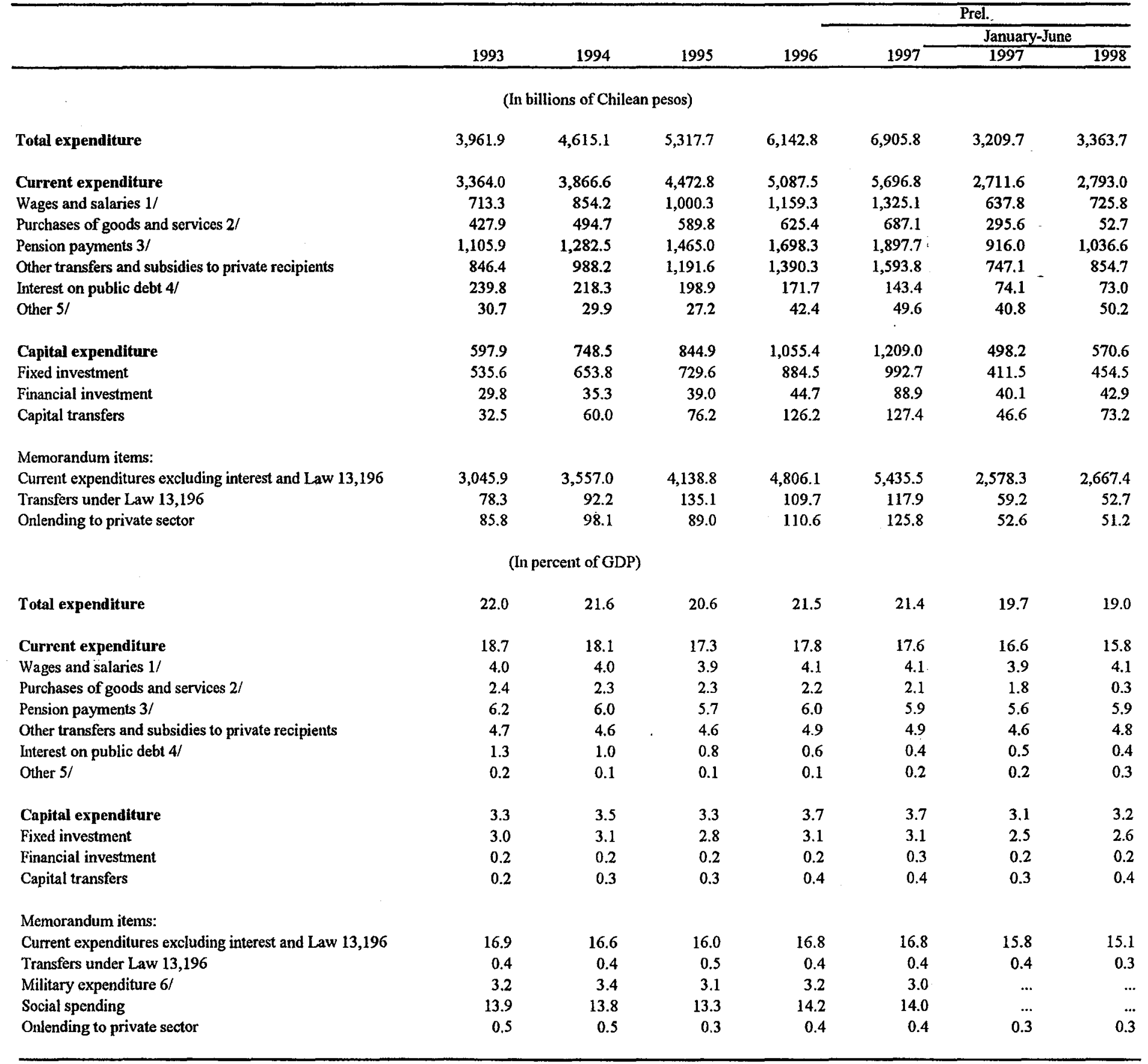

Sources: Ministry of Finance; and Fund staff estimates.

$1 /$ Includes employer contributions to the social security system.

2/ Assumes that funds transferred under Law 13,196 by CODELCO to an account for nilitary purchases are spent in the same year.

3 / Includes cash transfers of accumulated contributions of currently retired persons who in the past had moved to a private system.

4/Includes monetary correction.

5/Includes net expenditure of the Petroleum Stabilization Fund.

6/ Includes military pensions and amounts transferred directly by CODELCO for military purchases assuming that these transfers are spent in the same year. 


$$
-126-
$$

Table 16. Chile: Operations of the Public Enterprises

\begin{tabular}{|c|c|c|c|c|c|c|c|}
\hline & \multirow[b]{2}{*}{1993} & \multirow[b]{2}{*}{1994} & \multirow[b]{2}{*}{1995} & \multirow[b]{2}{*}{1996} & \multicolumn{3}{|c|}{ Prel. } \\
\hline & & & & & $1997^{-}$ & $\frac{\text { January }}{1997}$ & 1998 \\
\hline \multicolumn{8}{|c|}{ (In billions of Chilean pesos) } \\
\hline \multicolumn{8}{|c|}{ I. All Public Enterprises } \\
\hline Operating surplus before taxes and transfers & 923.1 & 1052.6 & 1635.7 & 1514.6 & 1437.4 & 776.2 & 647.5 \\
\hline Taxes and transfers & 643.6 & 845.5 & 1353.9 & 1195.0 & 1221.0 & 645.4 & 447.1 \\
\hline Current account surpius & 279.5 & 207.1 & 281.8 & 319.6 & 216.5 & 130.8 & 200.4 \\
\hline $\begin{array}{l}\text { Capital revenue (net) } 1 \text { / } \\
\text { Capital expenditure }\end{array}$ & $\begin{array}{r}-5.2 \\
287.4\end{array}$ & $\begin{array}{l}139.0 \\
314.4\end{array}$ & $\begin{array}{r}-4.7 \\
355.0\end{array}$ & $\begin{array}{r}75.4 \\
596.1\end{array}$ & $\begin{array}{r}68.6 \\
685.3\end{array}$ & $\begin{array}{r}3.0 \\
336.2\end{array}$ & $\begin{array}{r}2.8 \\
362.2\end{array}$ \\
\hline \multirow[t]{2}{*}{ Overall surplus or deficit( - ) } & -13.1 & 31.6 & -77.9 & -201.1 & -400.3 & -202.4 & -159.1 \\
\hline & \multicolumn{3}{|c|}{ II. CODELCO } & & \multicolumn{3}{|c|}{ i } \\
\hline $\begin{array}{l}\text { Operating surplus before taxes and transfers } \\
\text { Taxes and transfers }\end{array}$ & $\begin{array}{l}371.1 \\
190.0\end{array}$ & $\begin{array}{l}388.2 \\
350.0\end{array}$ & $\begin{array}{l}881.1 \\
706.0\end{array}$ & $\begin{array}{l}568.2 \\
404.7\end{array}$ & $\begin{array}{l}585.0 \\
443.0\end{array}$ & $\begin{array}{l}320.3 \\
258.2\end{array}$ & $\begin{array}{r}191.7 \\
83.9\end{array}$ \\
\hline Current account surplus & 181.1 & 38.2 & 175.1 & 163.4 & 141.9 & 62.1 & 107.8 \\
\hline $\begin{array}{l}\text { Capital revenue (net) } \\
\text { Capital expenditure }\end{array}$ & 2.7 & 142.8 & $\begin{array}{r}3.2 \\
140.5\end{array}$ & 74.9 & 67.8 & 1.8 & 2.0 \\
\hline Overall surplus or deficit(-) & 28.4 & 21.2 & 37.7 & -52.2 & -201.8 & -163.4 & $-101,3$ \\
\hline \multicolumn{8}{|c|}{ III. Other Public Enterprises } \\
\hline Operating surplus before taxes and transfers & 552.0 & 664.4 & 754.6 & 946.4 & 852.5 & 456.0 & 455.8 \\
\hline Taxes and transfers & 453.5 & 495.5 & 647.9 & 790.3 & 777.9 & 387.2 & 363.2 \\
\hline Current account surplus & $\mathbf{9 8 . 4}$ & 168.9 & 106.7 & 156.1 & 74.6 & 68.7 & 92.5 \\
\hline $\begin{array}{l}\text { Capital revenue (net) 1/ } \\
\text { Capital expenditure }\end{array}$ & $\begin{array}{r}-8.0 \\
132.0\end{array}$ & $\begin{array}{r}-3.8 \\
154.7\end{array}$ & $\begin{array}{r}-7.9 \\
214.5\end{array}$ & $\begin{array}{r}0.4 \\
305.5\end{array}$ & $\begin{array}{r}0.8 \\
273.8\end{array}$ & $\begin{array}{r}1.2 \\
108.9\end{array}$ & $\begin{array}{r}0.8 \\
151.1\end{array}$ \\
\hline Overall surplus or deficit(-) & -41.5 & 10.4 & -115.7 & -149.0 & -198.5 & -39.0 & -57.8 \\
\hline \multicolumn{8}{|c|}{ (In percent of GDP) } \\
\hline \multicolumn{8}{|c|}{ I. All Public Enterprises } \\
\hline $\begin{array}{l}\text { Operating surplus before taxes and transfers } \\
\text { Taxes and transfers }\end{array}$ & $\begin{array}{l}5.1 \\
3.6\end{array}$ & 4.9 & 6.3 & 5.3 & 4.4 & 4.8 & 3.7 \\
\hline Current account surplus & 1.6 & 1.0 & 1.1 & 1.1 & 0.7 & 0.8 & 11 \\
\hline Capital revenue (net) $1 /$ & 0.0 & 0.6 & 0.0 & 0.3 & 0.2 & 0.0 & 0.0 \\
\hline Capital expenditure & 1.6 & 1.5 & 1.4 & 2.1 & 2.1 & 2.1 & 2.0 \\
\hline Overall surplus or deficit(-) & -0.1 & 0.1 & -0.3 & -0.7 & -1.2 & -1.2 & -0.9 \\
\hline \multicolumn{8}{|c|}{ II. CODELCO } \\
\hline Operating surplus before taxes and transfers & 2.1 & 1.8 & 3.4 & 2.0 & 1.8 & 2.0 & 1.1 \\
\hline Taxes and transfers & 1.1 & 1.6 & 2.7 & 1.4 & 1.4 & 1.6 & 0.5 \\
\hline Current account surplus & 1.0 & 0.2 & 0.7 & 0.6 & 0.4 & 0.4 & 0.6 \\
\hline Capital revenue (net) & 0.0 & 0.7 & 0.0 & 0.3 & 0.2 & 0.0 & 0.0 \\
\hline Capital expenditure & 0.9 & 0.7 & 0.5 & 1.0 & 1.3 & 1.4 & 1.2 \\
\hline Overall surplus or deficit(-) & 0.2 & 0.1 & 0.1 & -0.2 & -0.6 & -1.0 & -0.6 \\
\hline \multicolumn{8}{|c|}{ III. Other Public Enterprises } \\
\hline Operating surplus before taxes and transfers & 3.1 & 3.1 & 2.9 & 3.3 & 2.6 & 2.8 & 2.6 \\
\hline Taxes and transfers & 2.5 & 2.3 & 2.5 & 2.8 & 2.4 & 2.4 & 2.1 \\
\hline Current account surplus & 0.5 & 0.8 & 0.4 & 0.5 & 0.2 & 0.4 & 0.5 \\
\hline Capital revenue (net) $1 /$ & 0.0 & 0.0 & 0.0 & 0.0 & 0.0 & 0.0 & 0.0 \\
\hline Capital expenditure & 0.7 & 0.7 & 0.8 & 1.1 & 0.8 & 0.7 & 0.9 \\
\hline Overall surplus or deficit(-) & -0.2 & 0.0 & -0.4 & $=0.5$ & -0.6 & -0.2 & .0 .3 \\
\hline
\end{tabular}

Source: Ministry of Finance.

1/ Net of on-lending operations by the state holding company CORFO. 
Table 17. Chile: Summary Operations of CODELCO

\begin{tabular}{|c|c|c|c|c|c|c|c|}
\hline & \multirow[b]{3}{*}{1993} & \multirow[b]{3}{*}{1994} & \multirow[b]{3}{*}{1995} & \multirow[b]{3}{*}{1996} & \multicolumn{3}{|c|}{ Prel. } \\
\hline & & & & & \multicolumn{3}{|c|}{ January-June } \\
\hline & & & & & 1997 & 1997 & 1998 \\
\hline \multicolumn{8}{|c|}{ (In billions of Chilean pesos) } \\
\hline Current revenue & $1,103.5$ & $1,258.2$ & $1,665.5$ & $1,354.7$ & $1,540.2^{2}$ & 788.8 & 669.1 \\
\hline Sales of goods and services & $1,021.6$ & $1,180.4$ & $1,580.9$ & $1,289.8$ & $1,470.2$ & $751.9-$ & 653.2 \\
\hline Other & 81.9 & 82.3 & 84.6 & 64.9 & 70.0 & 37.0 & 15.9 \\
\hline Current expenditure & 732.4 & 870.0 & 784.4 & 786.6 & 955.2 & 468.6 & 477.4 \\
\hline Wages and salaries $1 /$ & 256.4 & 292.5 & 248.1 & 269.1 & 282.1 & 148.6 & 134.2 \\
\hline Purchases of goods and services & 459.1 & 562.4 & 518.8 & 493.9 & 642.8 & 309.2 & 326.0 \\
\hline Interest payments & 17.0 & 15.8 & 17.6 & 23.5 & 30.2 & 10.8 & 17.2 \\
\hline Operating surplus & 371.1 & 388.2 & 881.1 & 568.2 & 585.0 & 320.3 & 191.7 \\
\hline Less: taxes and transfer payments & -250.3 & -418.6 & -760.4 & -492.1 & .590 .9 & -333.8 & -158.9 \\
\hline Plus: transfer receipts & 60.2 & 65.6 & 54.4 & 87.4 & 147.8 & 75.7 & 75.0 \\
\hline Current account surplus or deficit $(-)$ & 181.1 & 38.2 & 175.1 & 163.4 & 141.9 & 62.1 & 107.8 \\
\hline Net capital revenue & 2.7 & 142.8 & 3.2 & 74.9 & 67.8 & 1.8 & 2.0 \\
\hline Revenue & 4.1 & 142.7 & 3.2 & 239.6 & 72.5 & 3.9 & 5.3 \\
\hline Less: financial investment and other capital transfers & -1.3 & -0.1 & 0.0 & -164.7 & -4.7 & -2.0 & -3.3 \\
\hline Fixed investment & 155.4 & 159.9 & 140.5 & 290.5 & 411.5 & 227.3 & 211.2 \\
\hline Overall surplus or deficit(-) & 28.4 & 21.0 & 37.7 & -52.2 & -201.8 & -163.4 & -101.3 \\
\hline Financing & -28.4 & -21.0 & -37.7 & 52.2 & 201.8 & 163.4 & 101.3 \\
\hline Foreign & -22.2 & 18.2 & 17.2 & 4.7 & 92.2 & $\ldots$ & ... \\
\hline Domestic & -6.2 & -39.2 & -54.9 & 47.4 & 109.5 & $\cdots$ & $\ldots$ \\
\hline \multicolumn{8}{|l|}{ Memorandum items: } \\
\hline CODELCO average export price $2 /$ & 75.7 & 93.0 & 125.4 & 94.8 & 94.6 & $\cdots$ & $\cdots$ \\
\hline \multicolumn{8}{|l|}{ Average price at the } \\
\hline London Metal Exchange 2/ & 86.9 & 104.9 & 133.2 & 103.2 & 103.2 & $\cdots$ & $\cdots$ \\
\hline Copper Stabilization Fund: deposits $(+) /$ withdrawals $(-) 3$ / & -0.2 & 0.2 & 1.1 & 0.3 & 0.1 & 0.2 & -0.3 \\
\hline Transfers under Law 13,196 3/ & 0.4 & 0.4 & 0.5 & 0.4 & 0.4 & 0.4 & 0.3 \\
\hline
\end{tabular}

Sources: Ministry of Finance; and Fund staff estimates.

1/ Includes employer contributions to the social security system.

2/ U.S. cents per pound.

3/ In percent of GDP. 
Table 18. Chile: Fiscal Impulse 1/

\begin{tabular}{|c|c|c|c|c|c|c|c|c|}
\hline & 1990 & 1991 & 1992 & 1993 & 1994 & 1995 & 1996 & 1997 \\
\hline \multicolumn{9}{|c|}{ (In percent of nominal GDP) } \\
\hline \multicolumn{9}{|l|}{ Actual } \\
\hline Revenue $2 /$ & 19.4 & 21.5 & 22.1 & 22.8 & 22.0 & 21.7 & 23.0 & 22.3 \\
\hline Expenditure 3/ & 18.1 & 18.6 & 19.1 & 19.7 & 19.4 & 18.6 & 19.8 & 19.8 \\
\hline \multicolumn{9}{|l|}{ Trend } \\
\hline Revenue & 21.2 & 21.2 & 21.2 & 21.2 & 21.2 & 21.2 & 21.2 & 21.2 \\
\hline Expenditure & 20.2 & 20.0 & 19.0 & 18.9 & 19.0 & 18.3 & 18.1 & 18.1 \\
\hline \multicolumn{9}{|l|}{ Actual less trend } \\
\hline Revenue & -1.7 & 0.3 & 1.0 & 1.6 & 0.8 & 0.5 & 1.8 & 1.2 \\
\hline Expenditure & -2.1 & -1.3 & 0.2 & 0.8 & 0.4 & 0.3 & 1.6 & 1.7 \\
\hline \multicolumn{9}{|c|}{ (In percent) } \\
\hline Total impulse 4/ & -0.3 & -1.3 & 0.9 & 0.0 & 0.5 & 0.1 & 0.1 & 0.7 \\
\hline Revenue impulse 5/ & 1.7 & -2.1 & -0.6 & -0.7 & 0.8 & 0.3 & -1.3 & 0.7 \\
\hline Expenditure impulse 5/ & -2.1 & 0.7 & 1.5 & 0.6 & -0.3 & -0.2 & 1.4 & 0.0 \\
\hline
\end{tabular}

Sources: Ministry of Finance; and Fund staff estimates.

1/ Operations of the general government only.

2/ Excludes proceeds from privatization and taxes and transfers from CODELCO.

3/ Excludes interest payments, transfers to private pension funds for balances accumulated under the previ pension scheme, and purchases financed by transfers from CODELCO.

4/ Sum of the revenue and expenditure impulses.

$5 /$ Change in the difference between actual and trend revenue (expenditure) in relation to the preceding ye 
Table 19. Chile: Real Interest Rates on Central Bank Notes and Operations of the Financial System

(In percent per annum)

\begin{tabular}{|c|c|c|c|c|c|}
\hline & \multicolumn{3}{|c|}{ Central Bank Notes } & \multicolumn{2}{|c|}{$\begin{array}{c}\text { Financial System Operations } \\
90 \text { to } 365 \text { Days }\end{array}$} \\
\hline & Interbank 1/ & 90 Days & 8 Years & Loans & Deposits \\
\hline 1993 & $\cdots$ & 6.5 & 7.0 & 9.2 & 6.4 \\
\hline 1994 & ... & 6.4 & 6.1 & 9.3 & 6.4 \\
\hline 1995 & 6.1 & 6.1 & 6.2 & 8.5 & 5.9 \\
\hline 1996 & 7.3 & 7.3 & 6.3 & 9.3 & 6.9 \\
\hline 1997 & 6.9 & 6.8 & 6.5 & 8.8 & 6.4 \\
\hline January & 7.5 & 7.3 & 6.1 & 9.2 & 6.9 \\
\hline February & 7.3 & 7.1 & 6.2 & 9.0 & 6.8 \\
\hline March & 7.2 & 6.9 & 6.2 & 9.1 & 6.6 \\
\hline April & 7.1 & 6.9 & 6.2 & 8.9 & 6.5 \\
\hline May & 7.0 & 6.9 & 6.3 & 8.9 & 6.5 \\
\hline June & 6.8 & 6.7 & 6.4 & 8.7 & 6.3 \\
\hline July & 6.8 & 6.7 & 6.5 & 8.7 & 6.4 \\
\hline August & 6.8 & 6.6 & 6.5 & 8.7 & 6.3 \\
\hline September & 6.6 & 6.5 & 6.7 & 8.5 & 6.2 \\
\hline October & 6.5 & 6.5 & 6.9 & 8.5 & 6.2 \\
\hline November & 6.5 & 6.5 & 6.8 & 8.5 & 6.2 \\
\hline December & 7.1 & 6.7 & 6.8 & 8.7 & 6.5 \\
\hline 1998 & 13.2 & 9.7 & 7.5 & 12.1 & 9.7 \\
\hline January & 18.9 & 8.5 & 7.1 & 10.2 & 7.8 \\
\hline February & 8.7 & 8.5 & 7.2 & 10.6 & 8.2 \\
\hline March & 8.4 & 8.3 & 7.1 & 10.2 & 8.0 \\
\hline April & 8.8 & 8.3 & 7.1 & 10.2 & 8.2 \\
\hline May & 8.5 & 8.3 & 7.2 & 10.4 & 8.3 \\
\hline June & 14.4 & 8.5 & 7.3 & 11.1 & 9.0 \\
\hline July & 16.5 & 9.3 & 7.5 & 13.2 & 10.8 \\
\hline August & 13.2 & 10.7 & 7.8 & 13.2 & 10.6 \\
\hline September & 25.8 & 17.6 & 8.9 & 19.1 & 15.7 \\
\hline October & 12.6 & 10.6 & 8.0 & 13.7 & 11.6 \\
\hline November & 9.7 & 8.3 & 7.3 & 10.9 & 8.3 \\
\hline
\end{tabular}

Sources: Central Bank of Chile; and Fund staff estimates.

1/ Since May 29, 1995 the interest rate on overnight operations between the central bank and commercial banks has been the main instrument of monetary policy. The values reported here are the equivalent real rate in annual terms. The central bank targets this rate. 
Table 20. Chile: Private Sector Holdings of Financial Assets

\begin{tabular}{|c|c|c|c|c|c|c|c|}
\hline & \multirow[b]{2}{*}{1993} & \multirow[b]{2}{*}{1994} & \multirow[b]{2}{*}{1995} & \multirow[b]{2}{*}{1996} & \multirow[b]{2}{*}{$1997^{-}$} & \multicolumn{2}{|c|}{ QII } \\
\hline & & & & & & 1997 & 1998 \\
\hline \multicolumn{8}{|c|}{ A. Annual rates of growth in percent } \\
\hline \multicolumn{8}{|c|}{ (In nominal terms) } \\
\hline Total liabilities (private sector) & 34.3 & 24.4 & 21.0 & 16.9 & 16.3 & 18.4 & 9.7 \\
\hline Currency & 21.1 & 14.5 & 17.7 & 9.5 & 14.6 & 10.5 & 7.9 \\
\hline Demand and sight deposits & 20.4 & 23.7 & 26.2 & 10.9 & 17.4 & 24.2 & 5.3 \\
\hline Narrow money (M1A) & 20.6 & 20.6 & 23.5 & 10.5 & 16.6 & 20.0 & 6.0 \\
\hline Savings and time deposits & 29.6 & 18.8 & 28.9 & 26.2 & 11.9 & 13.9 & 15.8 \\
\hline Broad money (M3) & 27.0 & 19.3 & 27.4 & 22.0 & 13.0 & 15.3 & 13.5 \\
\hline Pension fund liabilities & 44.2 & 31.5 & 15.0 & 13.0 & 15.9 & 20.0 & 2.7 \\
\hline Letters of credit & 39.3 & 47.8 & 54.7 & 29.0 & 62.3 & 41.0 & 39.6 \\
\hline Foreign currency deposits $2 /$ & 16.8 & -10.9 & -1.8 & -16.1 & 1.5 & 10.6 & 18.0 \\
\hline \multicolumn{8}{|c|}{ (In real terms) $3 /$} \\
\hline Total liabilities (private sector) & 19.7 & 14.2 & 11.8 & 9.6 & 9.7 & 13.2 & 4.3 \\
\hline Currency & 7.9 & 5.1 & 8.8 & 2.7 & 8.0 & 5.2 & 2.5 \\
\hline Demand and sight deposits & 7.2 & 13.5 & 16.6 & 4.0 & 10.7 & 18.9 & -0.1 \\
\hline Narrow money (M1A) & 7.5 & 10.7 & 14.1 & 3.6 & 9.9 & 14.8 & 0.6 \\
\hline Savings and time deposits & 15.4 & 9.0 & 19.1 & 18.4 & 5.5 & 8.6 & 10.4 \\
\hline Broad money (M3) & 13.2 & 9.5 & 17.8 & 14.5 & 6.6 & 10.0 & 8.0 \\
\hline Pension fund liabilities & 28.5 & 20.7 & 6.3 & 6.0 & 9.3 & 14.7 & -2.8 \\
\hline Letters of credit & 24.1 & 35.7 & 43.0 & 20.9 & 53.0 & 35.7 & 34.2 \\
\hline Foreign currency deposits $2 /$ & 4.0 & -18.3 & -9.3 & -21.3 & -4.3 & 5.3 & 12.6 \\
\hline \multicolumn{8}{|c|}{ B. Distribution } \\
\hline By issuer & 100.0 & 100.0 & 100.0 & 100.0 & 100.0 & 100.0 & 100.0 \\
\hline Central bank 4/ & 4.0 & 3.7 & 3.6 & 3.4 & 3.3 & 3.0 & 2.9 \\
\hline Bank and nonbank & 48.4 & 45.8 & 48.4 & 50.3 & 50.5 & 49.0 & 52.2 \\
\hline Pension funds & 47.6 & 50.5 & 48.0 & 46.3 & 46.1 & 48.0 & 44.8 \\
\hline By asset & 100.0 & 100.0 & 100.0 & 100.0 & 100.0 & 100.0 & 100.0 \\
\hline Currency & 4.0 & 3.7 & 3.6 & 3.4 & 3.3 & 3.0 & 2.9 \\
\hline Demand and sight deposits & 8.1 & 8.0 & 8.4 & 7.9 & 8.0 & 7.7 & 7.4 \\
\hline Narrow money (M1A) & 12.1 & 11.8 & 12.0 & 11.3 & 11.3 & 10.7 & 10.3 \\
\hline Savings and time deposits & 32.5 & 31.2 & 33.2 & 35.8 & 34.4 & 33.9 & 35.8 \\
\hline Broad money (M3) & 44.6 & 42.9 & 45.2 & 47.1 & 45.8 & 44.6 & 46.1 \\
\hline Pension fund liabilities & 47.6 & 50.5 & 48.0 & 46.3 & 46.1 & 48.0 & 44.8 \\
\hline Letters of credit & 2.6 & 3.1 & 4.0 & 4.4 & 6.1 & 5.0 & 6.3 \\
\hline Foreign currency deposits $2 /$ & 5.1 & 3.5 & 2.8 & 2.1 & 1.9 & 2.4 & 2.8 \\
\hline
\end{tabular}

Sources: Central Bank of Chile; and Fund staff estimates.

1/ Includes liabilities of pension funds to the private sector, but excludes intrafinancial flows as well as central bank notes and treasury notes in hands of the private sector.

$2 /$ Foreign deposits are valued at end-of-period exchange rates.

$3 /$ Nominal changes deflated by changes in the consumer price index.

4/ Excludes central bank promissory notes. 
Table 21. Chile: Operations of the Financial System

(Percentage change with respect to liabilities to the private sector at the beginning of the period) 1 .

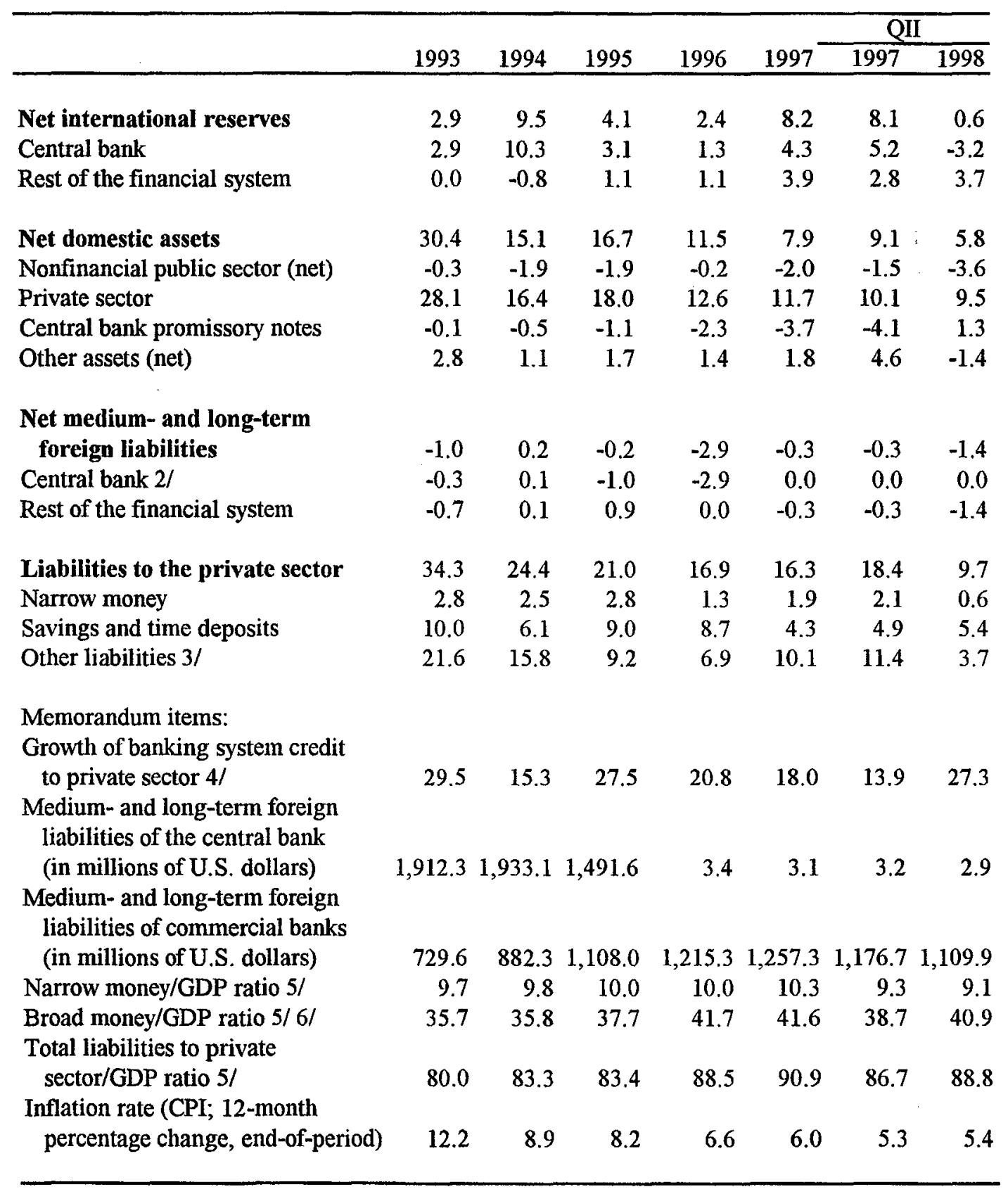

Sources: Central Bank of Chile; Superintendency of Pension Funds Administrators; and Fund st

1/ Flows measured at constant end-of-period exchange rates.

$2 /$ Includes liabilities on account of deposits placed by the corporate sector in the context of the rescheduling agreements with foreign commercial banks.

3/ Includes dollar deposits, mortgage bonds, and deposits with pension funds.

4/ Annual percentage change. Excludes pension funds.

$5 /$ Nominal quarterly GDP is Fund staff estimates.

6/ Broad money includes narrow money (MlA) plus savings and time deposits. 
Table 22. Chile: Operations of the Central Bank

(Percentage chage with respect to liabilities to the private sector at the beginning of the period) $1 /$

\begin{tabular}{|c|c|c|c|c|c|c|c|}
\hline & & & & & & QI & \\
\hline & 1993 & 1994 & 1995 & 1996 & 1997 & 1997 & 1998 \\
\hline Net international reserves & 63.9 & 255.0 & 82.5 & 36.6 & 126.8 & 164.4 & -106.7 \\
\hline Net domestic credit & -50.3 & -239.1 & -91.8 & -107.9 & -112.2 & -185.8 & 51.7 \\
\hline $\begin{array}{l}\text { Net credit to the nonfinancial } \\
\text { public sector } 2 /\end{array}$ & 1.4 & -48.3 & -19.1 & -24.1 & -40.7 & -58.4 & -75.5 \\
\hline $\begin{array}{l}\text { Net credit to financial } \\
\text { intermediaries }\end{array}$ & -169.3 & -232.6 & -164.9 & -67.0 & -116.5 & -172.4 & 71.0 \\
\hline Central bank promissory notes & -2.2 & -13.2 & -29.5 & -62.9 & -108.5 & -129.5 & 44.6 \\
\hline Credit to the private sector & -11.0 & 1.6 & -4.1 & -5.6 & -30.6 & -14.8 & -10.1 \\
\hline Capital and reserves & 60.0 & 23.3 & 7.2 & 52.0 & 64.9 & 86.1 & 57.1 \\
\hline Other & 70.9 & 30.1 & 118.6 & -0.4 & 119.2 & 126.5 & 5.5 \\
\hline Of which: capitalization notes & 24.1 & 14.2 & 16.3 & -17.5 & -1.5 & 19.3 & 79.6 \\
\hline subordinated debt & 34.2 & 12.3 & 10.2 & -9.0 & -192.5 & -221.9 & 0.0 \\
\hline $\begin{array}{l}\text { Net medium- and long-term } \\
\text { foreign liabilities } 3 \text { / }\end{array}$ & -17.3 & 3.6 & -66.4 & -190.1 & 0.0 & 0.0 & 0.0 \\
\hline Liabilities to the private sector & 21.1 & 14.5 & 17.7 & 9.5 & 14.6 & 10.5 & 7.9 \\
\hline Currency & 21.1 & 14.5 & 17.7 & 9.5 & 14.6 & 10.5 & 7.9 \\
\hline Memorandum items: & & & & & & & \\
\hline $\begin{array}{l}\text { Change in net international reserves } \\
\text { (in millions of U.S. dollars) }\end{array}$ & 711.7 & $3,668.0$ & $1,347.6$ & 674.3 & $2,471.3$ & $3,305.6$ & -827.6 \\
\hline $\begin{array}{l}\text { Change in medium- and long-term } \\
\text { foreign liabilities }\end{array}$ & & & & & & & \\
\hline (in millions of U.S. dollars) & -82.9 & 20.8 & -441.5 & $-1,488.2$ & -0.3 & -0.2 & -0.1 \\
\hline Inflation rate (CPI; 12 -month & & & & & & & \\
\hline percentage change, end-of-period) & 12.2 & 8.9 & 8.2 & 6.6 & 6.0 & 5.3 & 5.4 \\
\hline
\end{tabular}

Sources: Central Bank of Chile; and Fund staff estimates.

1/ Flows measured at constant end-of-period exchange rates.

2/ Excludes holdings of treasury notes on account of the 1983-86 capitalization of the central bank, which are included in other net domestic assets.

$3 /$ Includes foreign liabilities on account of deposits placed by the corporate sector in the central bank, in the context of the 1983-85 rescheduling agreements with foreign commercial banks. 
Table 23. Chile: Operations of Banks, Nonbanks, and Pension Funds

(Percentage change with respect to liabilities to the private sector at the beginning of the period) $1 /$

\begin{tabular}{|c|c|c|c|c|c|c|c|}
\hline & \multirow[b]{2}{*}{1993} & \multirow[b]{2}{*}{1994} & \multirow[b]{2}{*}{1995} & \multirow[b]{2}{*}{1996} & \multirow[b]{2}{*}{1997} & \multicolumn{2}{|c|}{ QII } \\
\hline & & & & & & 1997 & 1998 \\
\hline \multicolumn{8}{|c|}{ A. Bank and Nonbank Financial Intermediaries } \\
\hline Net international reserves & 0.1 & -1.7 & 2.3 & 2.2 & 7.7 & 5.7 & 7.6 \\
\hline Net domestic assets & 26.2 & 20.8 & 26.7 & 19.4 & 9.2 & 12.9 & 10.4 \\
\hline Nonfinancial public sector & -0.7 & -0.9 & -3.6 & -0.4 & -1.6 & -0.5 & -3.0 \\
\hline Net credit to financial intermediaries & -0.4 & 2.1 & 2.5 & -5.8 & -7.1 & -2.9 & -13.1 \\
\hline Credit to the private sector & 35.9 & 21.6 & 35.8 & 26.5 & 24.7 & 15.6 & 31.7 \\
\hline Capital and reserves & -2.9 & -2.9 & -3.0 & -2.4 & -2.7 & -2.5 & -2.2 \\
\hline Other & -5.6 & 0.8 & -5.1 & 1.5 & -4.0 & 3.3 & -3.0 \\
\hline $\begin{array}{l}\text { Net medium- and long-term } \\
\text { foreign liabilities }\end{array}$ & -0.7 & 0.9 & 1.1 & 0.4 & 0.1 & 0.0 & -0.2 \\
\hline Liabilities to the private sector $2 /$ & 26.9 & 18.2 & 27.9 & 21.2 & 16.7 & 17.9 & 15.1 \\
\hline \multicolumn{8}{|c|}{ B. Pension Funds } \\
\hline Net international reserves & 0.0 & 0.0 & 0.0 & 0.0 & 0.0 & 0.0 & 0.0 \\
\hline Net domestic assets & 43.4 & 30.9 & 15.7 & 12.6 & 15.1 & 19.4 & 0.0 \\
\hline Nonfinancial public sector & -0.1 & 1.1 & 1.0 & 1.8 & 0.4 & 1.3 & 0.2 \\
\hline Net credit to financial intermediaries & 20.3 & 17.6 & 9.4 & 10.2 & 13.5 & 10.3 & 10.3 \\
\hline Credit to the private sector & 23.0 & 12.3 & 3.5 & -0.2 & 0.8 & 7.1 & -10.6 \\
\hline Capital and reserves and other & 0.1 & -0.1 & 1.8 & 0.7 & 0.4 & 0.6 & 0.0 \\
\hline $\begin{array}{l}\text { Net medium- and long-term } \\
\text { foreign liabilities }\end{array}$ & -0.8 & -0.6 & 0.7 & -0.4 & -0.8 & -0.6 & -2.7 \\
\hline Liabilities to the private sector & 44.2 & 31.5 & 15.0 & 13.0 & 15.9 & 20.0 & 2.7 \\
\hline
\end{tabular}

Sources: Central Bank of Chile; Superintendency of Pension Funds Administrators; and Fund staff estimates.

1/ Flows measured at constant end-of-period exchange rates.

2/ Excludes deposits of pension funds.

$3 /$ Consists mostly of holdings of central bank promissory notes, commercial bank letters of credit, and time and savings deposits. 
Table 24. Chile: Summary Accounts of the Financial System

(End-of-period stocks; in billions of Chilean pesos)

\begin{tabular}{|c|c|c|c|c|c|c|c|c|c|c|}
\hline & & & & & & & & & \multicolumn{2}{|c|}{ June } \\
\hline & 1993 & 1994 & 1994 & 1995 & 1995 & 1996 & 1996 & 1997 & 1997 & 1998 \\
\hline & \multicolumn{2}{|c|}{$(\mathrm{Ch} \$ 404.09=\mathrm{US} \$ 1)$} & \multicolumn{2}{|c|}{$(\mathrm{Ch} \$ 407.13=\mathrm{US} \$ 1)$} & \multicolumn{2}{|c|}{$(\mathrm{Ch} \$ 424.97=\mathrm{US} \$ 1)$} & \multicolumn{2}{|c|}{$(\mathrm{Ch} \$ 439.81=\mathrm{US} \$ 1)$} & \multicolumn{2}{|c|}{$($ Ch\$469.185=US\$1) } \\
\hline Net international reserves & $2,700.7$ & $4,066.1$ & $4,096.7$ & $4,834.6$ & $5,046.5$ & $5,567.1$ & $5,761.6$ & $7,821.2$ & $7,288.1$ & $7,931.9$ \\
\hline Central bank & $3,727.8$ & $5,210.0$ & $5,249.2$ & $5,797.9$ & $6,051.9$ & $6,338.5$ & $6,559.8$ & $7,646.7$ & $7,519.5$ & $7,131.3$ \\
\hline Rest of the financial system $1 /$ & $-1,027.1$ & $-1,143.9$ & $-1,152.5$ & -963.2 & $-1,005.5$ & -771.3 & -798.3 & 174.5 & -231.5 & 800.6 \\
\hline Net domestic assets & $12,655.9$ & $14,815.1$ & $14,797.1$ & $17,775.1$ & $17,635.5$ & $20,128.1$ & $19,968.2$ & $21,951.6$ & $21,162.9$ & $22,929.5$ \\
\hline Nonfinancial public sector (net) & $-1,230.4$ & $-1,498.8$ & $-1,508.4$ & $-1,843.7$ & $-1,907.1$ & $-1,945.0$ & $-2,003.4$ & $-2,513.2$ & $-2,279.0$ & $-3,433.1$ \\
\hline Private sector & $11,768.1$ & $14,115.6$ & $14,125.6$ & $17,330.9$ & $17,406.8$ & $20,119.0$ & $20,179.5$ & $23,144.6$ & $21,053.0$ & $23,810.9$ \\
\hline Central bank promissory notes & $-1,479.9$ & $-1,556.9$ & $-1,556.9$ & $-1,752.9$ & $-1,752.9$ & $-2,245.0$ & $-2,245.0$ & $-3,174.9$ & $-3,035.5$ & $-2,663.1$ \\
\hline Other assets (net) & $3,598.2$ & $3,755.2$ & $3,736.8$ & $4,040.9$ & $3,888.7$ & $4,199.1$ & $4,037.1$ & $4,495.0$ & $5,424.4$ & $5,214.8$ \\
\hline $\begin{array}{l}\text { Net medium- and long-term } \\
\text { foreign liabilities }\end{array}$ & $1,067.6$ & $1,137.7$ & $1,146.2$ & $1,058.4$ & $1,104.7$ & 517.9 & 536.0 & 554.3 & 518.9 & 522.1 \\
\hline Central bank $3 /$ & 772.7 & 781.1 & 787.0 & 607.3 & 633.9 & 1.4 & 1.5 & 1.3 & 1.4 & 1.4 \\
\hline Rest of the financial system & 294.8 & 356.5 & 359.2 & 451.1 & 470.9 & 516.5 & 534.5 & 553.0 & 517.5 & 520.7 \\
\hline Liabilities to the private sector & $14,325.5$ & $17,824.3$ & $17,828.9$ & $21,572.4$ & $21,599.1$ & $25,240.4$ & $25,259.1$ & $29,373.0$ & $28,031.6$ & $30,804.7$ \\
\hline Narrow money & $1,738.3$ & $2,096.1$ & $2,096.1$ & $2,588.7$ & $2,588.7$ & $2,859.6$ & $2,859.6$ & $3,333.6$ & $2,990.9$ & $3,171.2$ \\
\hline Savings and time deposits & $4,677.2$ & $5,555.6$ & $5,555.6$ & $7,161.8$ & $7,161.8$ & $9,040.3$ & $9,040.3$ & $10,118.7$ & $9,512.2$ & $11,016.3$ \\
\hline Other liabilities 4/ & $7,910.0$ & $10,172.5$ & $10,177.1$ & $11,821.9$ & $11,848.6$ & $13,340.5$ & $13,359.2$ & $15,920.7$ & $15,528.5$ & $16,617.2$ \\
\hline
\end{tabular}

Source: Central Bank of Chile; Superintendency of Pension Funds Administrators; and Fund staff estimates.

1/ Consists of commercial banks, including the Banco del Estado, insurance companies, and the pension funds.

2/ Excludes holdings of treasury notes on account of the 1983-85 capitalization of the central bank. These notes are included in other assets.

3/ Includes foreign liabilities on account of deposits placed by the corporate sector in the central bank in the context of the 1983-85 rescheduling agreements with foreign commercial banks.

4/ Includes mortgage bonds, U.S. dollar deposits, and deposits with pension funds. 
Table 25. Chile: Summary Accounts of the Central Bank

(End-of-period stocks; in billions of Chilean pesos)

\begin{tabular}{|c|c|c|c|c|c|c|c|c|c|c|}
\hline & & & & & & & & & \multicolumn{2}{|c|}{ June } \\
\hline & 1993 & 1994 & 1994 & 1995 & 1995 & 1996 & 1996 & 1997 & 1997 & 1998 \\
\hline & \multicolumn{2}{|c|}{$($ Ch $\$ 404.09=$ US\$1) } & \multicolumn{2}{|c|}{$($ Ch\$407.13=US\$1) } & \multicolumn{2}{|c|}{$(C h \$ 424.97=U S \$ 1)$} & \multicolumn{2}{|c|}{$($ Ch\$439.81=US\$1) } & \multicolumn{2}{|c|}{$(\mathrm{Ch} \$ 469.185=\mathrm{US} \$ 1)$} \\
\hline Net international reserves & $3,727.8$ & $5,210.0$ & $5,249.2$ & $5,797.9$ & $6,051.9$ & $6,338.5$ & $6,559.8$ & $7,646.7$ & $7,519.5$ & $7,131.3$ \\
\hline In millions of U.S. dollars & $9,225.2$ & $12,893.2$ & $12,893.2$ & $14,240.8$ & $14,240.8$ & $14,915.1$ & $14,915.1$ & $17,386.4$ & $17,097.3$ & $15,199.3$ \\
\hline Net domestic assets & $-2,373.8$ & $-3,763.6$ & $-3,796.9$ & $-4,407.7$ & $-4,635.2$ & $-5,479.8$ & $-5,701.1$ & $-6,663.1$ & $-6,683.9$ & $-6,229.5$ \\
\hline \multicolumn{11}{|l|}{ Net credit to the nonfinancial } \\
\hline public sector $1 /$ & -887.6 & $-1,168.6$ & $-1,178.2$ & $-1,305.6$ & $-1,368.5$ & $-1,556.9$ & $-1,615.0$ & $-1,964.3$ & $-2,080.8$ & $-2,858.0$ \\
\hline \multicolumn{11}{|l|}{ Net credit to financial } \\
\hline intermediaries & $-4,224.6$ & $-5,576.3$ & $-5,576.3$ & $-6,673.2$ & $-6,673.2$ & $-7,198.0$ & $-7,198.0$ & $-8,196.9$ & $-8,166.5$ & $-7,574.6$ \\
\hline Central bank promissory notes & $-1,479.9$ & $-1,556.9$ & $-1,556.9$ & $-1,752.9$ & $-1,752.9$ & $-2,245.0$ & $-2,245.0$ & $-3,174.9$ & $-3,035.5$ & $-2,663.1$ \\
\hline Credit to the private sector & -45.0 & -35.6 & -35.8 & -63.4 & -66.2 & -110.0 & -113.9 & -376.1 & -223.0 & -291.9 \\
\hline Capital and reserves & -428.6 & -293.1 & -294.9 & -247.0 & -266.2 & 141.3 & 127.1 & 683.8 & 402.6 & 893.3 \\
\hline Other & $4,692.0$ & $4,866.8$ & $4,845.3$ & $5,634.5$ & $5,491.9$ & $5,488.9$ & $5,343.7$ & $6,365.2$ & $6,419.3$ & $6,264.9$ \\
\hline Of which: capitalization notes & $3,136.2$ & $3,218.5$ & $3,239.0$ & $3,347.6$ & $3,472.2$ & $3,335.0$ & $3,434.0$ & $3,421.0$ & $3,488.6$ & $4,152.5$ \\
\hline subordinated debt $2 /$ & $1,581.1$ & $1,652.8$ & $1,652.8$ & $1,720.7$ & $1,720.7$ & $1,650.0$ & $1,650.0$ & 0.0 & 0.0 & 0.0 \\
\hline \multicolumn{11}{|l|}{ Net medium- and long-term } \\
\hline foreign liabilities 3 / & 772.7 & 781.1 & 787.0 & 607.3 & 633.9 & 1.4 & 1.5 & 1.3 & 1.4 & 1.4 \\
\hline In millions of U.S. dollars & $1,912.3$ & $1,933.1$ & $1,933.1$ & $1,491.6$ & $1,491.6$ & 3.4 & 3.4 & 3.1 & 3.2 & 2.9 \\
\hline Liabilities to the private sector & 581.2 & 665.3 & 665.3 & 782.9 & 782.9 & 857.3 & 857.3 & 982.2 & 834.3 & 900.4 \\
\hline Currency in circulation & 581.2 & 665.3 & 665.3 & 782.9 & 782.9 & 857.3 & 857.3 & 982.2 & 834.3 & 900.4 \\
\hline
\end{tabular}

Sources: Central Bank of Chile, and Fund staff estimates.

1/ Excludes holdings of treasury notes on account of the 1983-86 capitalization of the central bank, which are included in other net domestic assets.

2/ Substandard loans to the private sector taken over by the central bank in 1984-87.

3/ Includes foreign liabilities on account of deposits placed by the corporate sector in the central bank in the context of the 1983-85 rescheduling agreements with

foreign commercial banks. 
Table 26. Chile: Summary Accounts of Banks and Nonbanks Financial Intermediaries 1/

(End-of-period stocks; in billions of Chilean pesos)

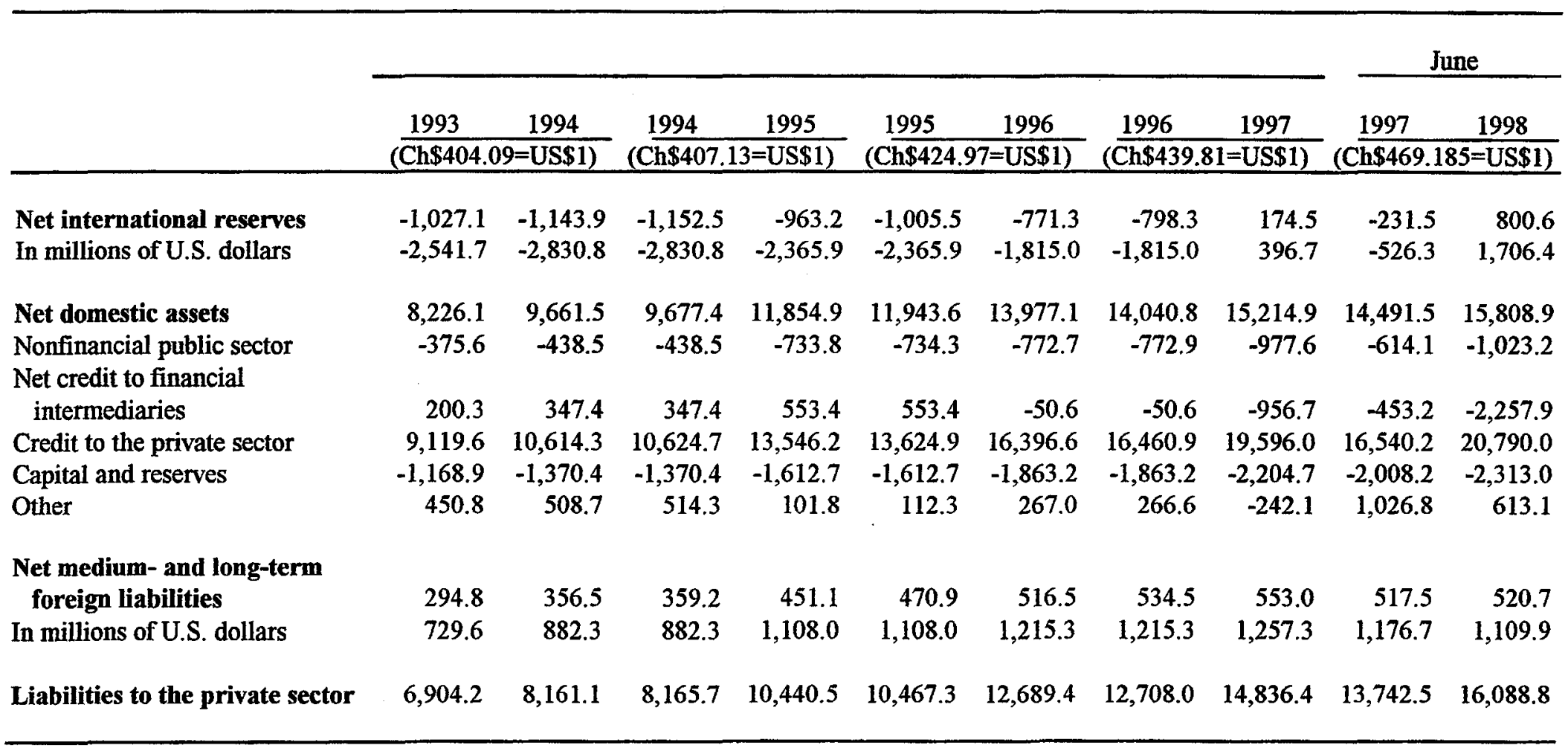

Sources: Central Bank of Chile; and Fund staff estimates.

1/ Excludes the pension funds. 
Table 27. Chile: Summary Accounts of Pension Funds

(End-of-period stocks; in billions of Chilean pesos)

\begin{tabular}{|c|c|c|c|c|c|c|c|c|c|c|}
\hline & & & & & & & & & \multicolumn{2}{|c|}{ June } \\
\hline & 1993 & 1994 & 1994 & 1995 & 1995 & 1996 & 1996 & 1997 & 1997 & 1998 \\
\hline & \multicolumn{2}{|c|}{$\overline{(C h \$ 404.09=U S \$ 1)}$} & \multicolumn{2}{|c|}{$\overline{(\mathrm{Ch} \$ 407.13=\mathrm{US} \$ 1)}$} & \multicolumn{2}{|c|}{$(\mathrm{Ch} \$ 424.97=\mathrm{US} \$ 1)$} & \multicolumn{2}{|c|}{$(\mathrm{Ch} \$ 439.81=\mathrm{US} \$ 1)$} & \multicolumn{2}{|c|}{$(\mathrm{Ch} \$ 469.185=\mathrm{US} \$ 1)$} \\
\hline Net international reserves & 0.0 & 0.0 & 0.0 & 0.0 & 0.0 & 0.0 & 0.0 & 0.0 & 0.0 & 0.0 \\
\hline In millions of U.S. dollars & 0.0 & 0.0 & 0.0 & 0.0 & 0.0 & 0.0 & 0.0 & 0.0 & 0.0 & 0.0 \\
\hline Net domestic assets & $6,803.6$ & $8,917.1$ & $8,916.5$ & $10,328.0$ & $10,327.1$ & $11,630.7$ & $11,628.5$ & $13,399.9$ & $13,355.3$ & $13,350.1$ \\
\hline Nonfinancial public sector & 32.8 & 108.3 & 108.3 & 195.7 & 195.7 & 384.5 & 384.5 & 428.7 & 415.9 & 448.1 \\
\hline $\begin{array}{l}\text { Net credit to financial } \\
\text { intermediaries }\end{array}$ & $4,122.8$ & $5,326.0$ & $5,326.0$ & $6,175.2$ & $6,175.2$ & $7,231.1$ & $7,231.1$ & $8,813.4$ & $7,991.6$ & $9,374.6$ \\
\hline Credit to the private sector & $2,693.5$ & $3,536.8$ & $3,536.8$ & $3,848.1$ & $3,848.1$ & $3,832.4$ & $3,832.4$ & $3,924.8$ & $4,735.8$ & $3,312.9$ \\
\hline Capital and reserves & 5.5 & 2.1 & 2.1 & 9.6 & 9.6 & 2.7 & 2.7 & 10.8 & 11.5 & 11.7 \\
\hline Other & -51.0 & -56.0 & -56.6 & 99.4 & 98.5 & 180.0 & 177.8 & 222.2 & 200.4 & 202.7 \\
\hline $\begin{array}{l}\text { Net medium- and long-term } \\
\text { foreign liabilities }\end{array}$ & -36.5 & -80.8 & -81.4 & -21.0 & -22.0 & -63.1 & -65.3 & -154.5 & -99.6 & -465.4 \\
\hline Liabilities to the private sector & $6,840.1$ & $8,997.9$ & $8,997.9$ & $10,349.0$ & $10,349.0$ & $11,693.8$ & $11,693.8$ & $13,554.4$ & $13,454.8$ & $13,815.5$ \\
\hline
\end{tabular}

Sources: Central Bank of Chile; Superintendency of Pension Funds Administrators; and Fund staff estimates. 
Table 28. Chile: Pension Funds--Selected Indicators

(End-of-period values; unless otherwise indicated)

\begin{tabular}{|c|c|c|c|c|c|c|}
\hline & 1993 & 1994 & 1995 & 1996 & 1997 & $\begin{array}{c}\text { Sep. } \\
1998\end{array}$ \\
\hline \multicolumn{7}{|c|}{ (In thousands of persons) } \\
\hline $\begin{array}{l}\text { Number of affiliates } \\
\text { Contributors (cotizantes) 1/2/ }\end{array}$ & $\begin{array}{r}4,708.8 \\
2366.7 \\
\\
\text { n percent }\end{array}$ & $\begin{array}{r}5,014.4 \\
2879.6 \\
\\
\text { per annu }\end{array}$ & $\begin{array}{r}5,320.9 \\
2961.9 \\
\\
\text { n) }\end{array}$ & $\begin{array}{r}5,571.5 \\
3121.1\end{array}$ & $\begin{array}{r}5,780.4 \\
3296.4\end{array}$ & $\begin{array}{r}5,869.6 \\
3240.9\end{array}$ \\
\hline Real rate of return of pension funds & 16.2 & 18.2 & -2.5 & 3.5 & 4.7 & -9.6 \\
\hline \multicolumn{7}{|c|}{ (As a percentage of annual GDP) } \\
\hline \multicolumn{7}{|c|}{ (As a percentage of total assets) } \\
\hline Pension funds portfolio composition & & & & & & \\
\hline $\begin{array}{l}\text { Total assets } \\
\text { Government securities } \\
\text { Financial institutions instruments } \\
\text { Firms shares and debentures } \\
\text { Foreign assets } 3 / \\
\text { Other }\end{array}$ & $\begin{array}{r}100.0 \\
39.3 \\
20.7 \\
39.4 \\
0.6 \\
0.1\end{array}$ & $\begin{array}{r}100.0 \\
39.7 \\
20.1 \\
39.3 \\
0.9 \\
0.0\end{array}$ & $\begin{array}{r}100.0 \\
39.4 \\
23.1 \\
37.2 \\
0.2 \\
0.1\end{array}$ & $\begin{array}{r}100.0 \\
42.1 \\
24.6 \\
32.8 \\
0.5 \\
0.0\end{array}$ & $\begin{array}{r}100.0 \\
39.6 \\
30.1 \\
29.0 \\
1.2 \\
0.1\end{array}$ & $\begin{array}{r}100.0 \\
42.4 \\
32.5 \\
19.8 \\
5.3 \\
0.1\end{array}$ \\
\hline
\end{tabular}

Sources: Central Bank of Chile; Superintendency of the AFPs; and Fund staff estimates.

1/ Data for 1998 correspond to August.

$2 /$ Includes all workers afiliated to an AFP that during the specified month pay, or declare and do not pay, the contributions to the pension fund.

3/ Until May 1993 pension funds were not allowed to invest in foreign assets. Currently, they can invest up to 12 percent of the value of the fund. 
Table 29. Chile: Export and Import Values, Volumes and Prices, and Terms of Trade

(Annual percentage changes)

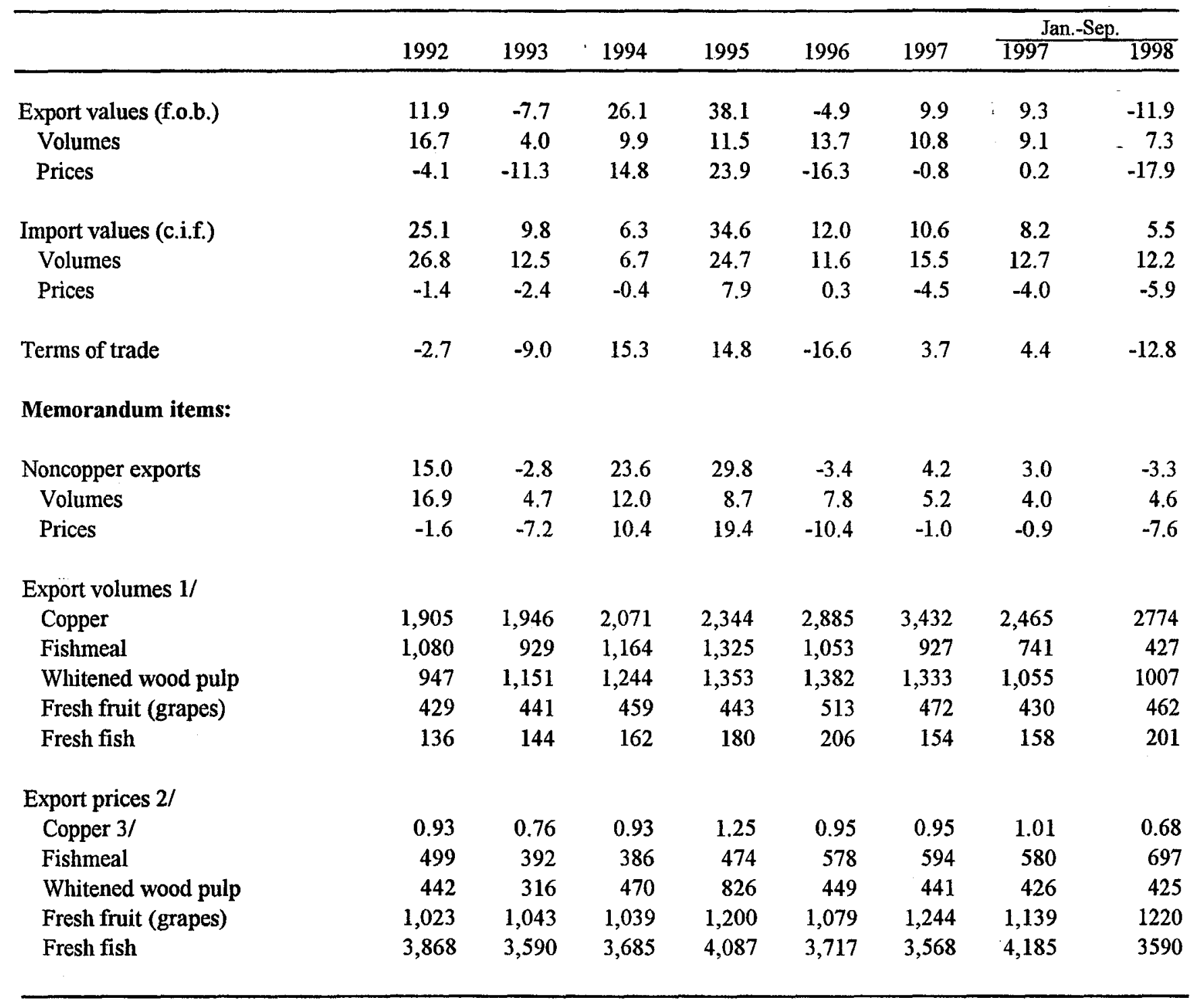

Source: Central Bank of Chile.

1/ Thousands of metric tons.

2/ U.S. dollars per metric ton.

3/ U.S. dollars per pound. 
Table 30. Chile: Exports (f.o.b.) by Main Categories

\begin{tabular}{|c|c|c|c|c|c|c|c|c|}
\hline & \multirow[b]{2}{*}{1992} & \multirow[b]{2}{*}{1993} & \multirow[b]{2}{*}{1994} & \multirow[b]{2}{*}{1995} & \multirow[b]{2}{*}{1996} & \multirow[b]{2}{*}{1997} & \multicolumn{2}{|c|}{ Jan.-Sep. } \\
\hline & & & & & & & 1997 & 1998 \\
\hline \multicolumn{9}{|c|}{ (In millions of U.S. dollars) } \\
\hline Total & 10,008 & 9,199 & 11,604 & 16,137 & 15,353 & 16,921 & 13,006 & 11,408 \\
\hline Mining products & 4,724 & 3,976 & 5,191 & 7,850 & 7,324 & 8,466 & 6,467 & 5058 \\
\hline Copper & 3,886 & 3,248 & 4,242 & 6,487 & 6,029 & 7,156 & 5,464 & 4164 \\
\hline CODELCO & 2,231 & 1,776 & 2,226 & 3,116 & 2,391 & 2,942 & 2,301 & 1755 \\
\hline Other & 1,655 & 1,472 & 2,016 & 3,371 & 3,638 & 4214 & 3,163 & 2409 \\
\hline Other & 838 & 728 & 949 & 1,363 & 1,295 & 1310 & 1,003 & 894 \\
\hline Agricultural and fishery products & 1,803 & 1,722 & 1,960 & 2,398 & 2,442 & 2,514 & 2,106 & 2,078 \\
\hline Fresh fruit & 968 & 845 & 923 & 1,117 & 1,205 & 1,129 & 1,036 & 1067 \\
\hline Fresh fish $1 /$ & 563 & 569 & 683 & 858 & 877 & 1,011 & 772 & 726 \\
\hline Other & 272 & 308 & 354 & 423 & 360 & 374 & 298 & 285 \\
\hline Semi-industrial and industrial products & 3,481 & 3,501 & 4,453 & 5,889 & 5,587 & 5,941 & 4,433 & 4272 \\
\hline Fishmeal & 538 & 364 & 449 & 628 & 608 & 550 & 430 & 298 \\
\hline Woodchips & 164 & 137 & 164 & 233 & 171 & 147 & 114 & 95 \\
\hline Woodpulp & 527 & 444 & 716 & 1,316 & 670 & 678 & 523 & 500 \\
\hline Other & 2,252 & 2,556 & 3,124 & 3,712 & 4,138 & 4,566 & 3,366 & 3,379 \\
\hline \multicolumn{9}{|c|}{ (In percent of total exports) } \\
\hline Total & 100.0 & 100.0 & 100.0 & 100.0 & 100.0 & 100.0 & 100.0 & 100.0 \\
\hline Mining products & 47.2 & 43.2 & 44.7 & 48.6 & 47.7 & 50.0 & 49.7 & 44.3 \\
\hline Copper & 38.8 & 35.3 & 36.6 & 40.2 & 39.3 & 42.3 & 42.0 & 36.5 \\
\hline Agricultural and fishery products & 18.0 & 18.7 & 16.9 & 14.9 & 15.9 & 14.9 & 16.2 & 18.2 \\
\hline Fresh fruit & 9.7 & 9.2 & 8.0 & 6.9 & 7.8 & 6.7 & 8.0 & 9.4 \\
\hline Fresh fish $1 /$ & 5.6 & 6.2 & 5.9 & 5.3 & 5.7 & 6.0 & 5.9 & 6.4 \\
\hline Other & 2.7 & 3.3 & 3.1 & 2.6 & 2.3 & 2.2 & 2.3 & 2.5 \\
\hline Semi-industrial and industrial products & 34.8 & 38.1 & 38.4 & 36.5 & 36.4 & 35.1 & 34.1 & 37.4 \\
\hline Fishmeal & 5.4 & 4.0 & 3.9 & 3.9 & 4.0 & 3.3 & 3.3 & 2.6 \\
\hline Woodchips & 1.6 & 1.5 & 1.4 & 1.4 & 1.1 & 0.9 & 0.9 & 0.8 \\
\hline Woodpulp & 5.3 & 4.8 & 6.2 & 8.2 & 4.4 & 4.0 & 4.0 & 4.4 \\
\hline Other & 22.5 & 27.8 & 26.9 & 23.0 & 27.0 & 27.0 & 25.9 & 29.6 \\
\hline \multicolumn{9}{|c|}{ (In percent of GDP) $2 /$} \\
\hline Total & 23.9 & 20.7 & 22.8 & 24.7 & 22.2 & 22.0 & 22.8 & 19.8 \\
\hline Copper & 9.3 & 7.3 & 8.3 & 9.9 & 8.7 & 9.3 & 9.6 & 7.2 \\
\hline
\end{tabular}

Sources: Central Bank of Chile; and Fund staff estimates.

1/ Includes frozen and semi-processed fish.

$2 /$ Nominal quarterly GDP figures are Fund staff estimates. 
Table 31. Chile: Imports (c.i.f.) by Type of Goods $1 / 2 /$

\begin{tabular}{|c|c|c|c|c|c|c|c|c|}
\hline & \multirow[b]{2}{*}{1992} & \multirow[b]{2}{*}{1993} & \multirow[b]{2}{*}{1994} & \multirow[b]{2}{*}{1995} & \multirow[b]{2}{*}{1996.} & \multirow[b]{2}{*}{1997} & \multicolumn{2}{|c|}{ Jan.-Jun. } \\
\hline & & & & & & & 1997 & 1998 \\
\hline \multicolumn{9}{|c|}{ (In millions of U. S. dollars) } \\
\hline Total imports & 10,129 & 11,125 & 11,827 & 15,914 & 17,828 & 19,659 & 10,562 & 11,722 \\
\hline Consumer goods & 1,576 & 1,762 & 1,865 & 2,669 & 3,160 & 3,480 & 1,792 & 2,015 \\
\hline Agriculture & 28 & 38 & 35 & 39 & 41 & 45 & 22 & 24 \\
\hline Industrial & 1,548 & 1,725 & 1,829 & 2,630 & 3,119 & 3,435 & 1,770 & 1,991 \\
\hline Intermediate goods & 5,390 & 5,804 & 6,086 & 8,138 & 8,993 & 9,458 & 5,261 & 5,597 \\
\hline Agricultural & 199 & 202 & 266 & 321 & 429 & 342 & 169 & 157 \\
\hline Mining & 918 & 912 & 918 & 1,227 & 1,458 & 1,432 & 859 & 738 \\
\hline Of which: crude oil & 833 & 780 & 748 & 906 & 1,159 & 1,131 & 683 & 537 \\
\hline Industrial & 4,273 & 4,691 & 4,903 & 6,590 & 7,106 & 7,684 & 4,233 & 4,702 \\
\hline Of which: petroleum product & 275 & 294 & 396 & 257 & 372 & 378 & 250 & 187 \\
\hline Capital goods & 2,473 & 2,969 & 3,190 & 4,091 & 4,652 & 5,166 & 2,770 & 3,032 \\
\hline Agricultural & 1 & 1 & 1 & 1 & 2 & 1 & 1 & 1 \\
\hline Industrial & 2,471 & 2,967 & 3,186 & 4,088 & 4,645 & 5,161 & 2,765 & 3,029 \\
\hline Other & 1 & 1 & 3 & 3 & 5 & 4 & 3 & 2 \\
\hline Unclassified & 689 & 590 & 685 & 1,016 & 1,023 & 1,555 & 739 & 1,078 \\
\hline $\begin{array}{l}\text { Memorandum item: } \\
\text { Imports of automobiles }\end{array}$ & 477 & 445 & 407 & 687 & 799 & 839 & 444 & 448 \\
\hline \multicolumn{9}{|c|}{ (In percent of total imports) } \\
\hline Total imports & 100.0 & 100.0 & 100.0 & 100.0 & 100.0 & 100.0 & 100.0 & 100.0 \\
\hline Consumer goods & 15.6 & 15.8 & 15.8 & 16.8 & 17.7 & 17.7 & 17.0 & 17.2 \\
\hline Agriculture & 0.3 & 0.3 & 0.3 & 0.2 & 0.2 & 0.2 & 0.2 & 0.2 \\
\hline Industrial & 15.3 & 15.5 & 15.5 & 16.5 & 17.5 & 17.5 & 16.8 & 17.0 \\
\hline Intermediate goods & 53.2 & 52.2 & 51.5 & 51.1 & 50.4 & 48.1 & 49.8 & 47.7 \\
\hline Agricultural & 2.0 & 1.8 & 2.2 & 2.0 & 2.4 & 1.7 & 1.6 & 1.3 \\
\hline Mining & 9.1 & 8.2 & 7.8 & 7.7 & 8.2 & 7.3 & 8.1 & 6.3 \\
\hline Of which: crude oil & 8.2 & 7.0 & 6.3 & 5.7 & 6.5 & n.a. & n.a. & n.a. \\
\hline Industrial & 42.2 & 42.2 & 41.5 & 41.4 & 39.9 & 39.1 & 40.1 & 40.1 \\
\hline Of which: petroleum product & 2.7 & 2.6 & 3.3 & n.a. & 2.1 & n.a. & n.a. & n.a. \\
\hline Capital goods & 24.4 & 26.7 & 27.0 & 25.7 & 26.1 & 26.3 & 26.2 & 25.9 \\
\hline Agricultural & 0.0 & 0.0 & 0.0 & 0.0 & 0.0 & 0.0 & 0.0 & 0.0 \\
\hline Industrial & 24.4 & 26.7 & 26.9 & 25.7 & 26.1 & 26.3 & 26.2 & 25.8 \\
\hline Other & 0.0 & 0.0 & 0.0 & 0.0 & 0.0 & 0.0 & 0.0 & 0.0 \\
\hline Unclassified & 6.8 & 5.3 & 5.8 & 6.4 & 5.7 & 7.9 & 7.0 & 9.2 \\
\hline Memorandum item: & & & & & & & & \\
\hline Imports of automobiles & 4.7 & 4.0 & 3.4 & 4.3 & 4.5 & 4.3 & 4.2 & 3.8 \\
\hline \multicolumn{9}{|c|}{ (In percent of GDP) 3/ } \\
\hline Total imports & 24.2 & 25.0 & 23.2 & 24.4 & 25.8 & 14.3 & 6.6 & 6.3 \\
\hline Consumer goods & 3.8 & 4.0 & 3.7 & 4.1 & 4.6 & 2.5 & 1.1 & 1.1 \\
\hline Agriculture & 0.1 & 0.1 & 0.1 & 0.1 & 0.1 & 0.0 & 0.0 & 0.0 \\
\hline Industrial & 3.7 & 3.9 & 3.6 & 4.0 & 4.5 & 2.5 & 1.1 & 1.1 \\
\hline Intermedliate goods & 12.9 & 13.1 & 12.0 & 12.5 & 13.0 & 6.9 & 3.3 & 3.0 \\
\hline Agricultural & 0.5 & 0.5 & 0.5 & 0.5 & 0.6 & 0.2 & 0.1 & 0.1 \\
\hline Mining & 2.2 & 2.1 & 1.8 & 1.9 & 2.1 & 1.0 & 0.5 & 0.4 \\
\hline Of which: crude oil & 2.0 & 1.8 & 1.5 & 1.4 & 1.7 & n.a. & n.a. & n.a. \\
\hline Industrial & 10.2 & 10.5 & 9.6 & 10.1 & 10.3 & 5.6 & 2.6 & 2.5 \\
\hline Of which: petroleum product & 0.7 & 0.7 & 0.8 & n.a. & 0.5 & n.a. & n.a. & n.a. \\
\hline Capital goods & 5.9 & 6.7 & 6.3 & 6.3 & 6.7 & 3.8 & 1.7 & 1.6 \\
\hline Agricultural & 0.0 & 0.0 & 0.0 & 0.0 & 0.0 & 0.0 & 0.0 & 0.0 \\
\hline Industrial & 5.9 & 6.7 & 6.3 & 6.3 & 6.7 & 3.8 & 1.7 & 1.6 \\
\hline Other & 0.0 & 0.0 & 0.0 & 0.0 & 0.0 & 0.0 & 0.0 & 0.0 \\
\hline Unclassified & 1.6 & 1.3 & 1.3 & 1.6 & 1.5 & 1.1 & 0.5 & 0.6 \\
\hline
\end{tabular}

Sources: Central Bank of Chile; and Fund staff estimates.

1/ Starting in 1990, some consumer and capital good imports were reclassified as intermediate imports to be consistent with national accounts criteria.

2/ Excludes imports through Free Trade Zones.

3/ Nominal quarterly GDP figures are Fund staff estimates. 
Table 32. Chile: Capital Goods Imports

(In millions of U.S. dollars)

\begin{tabular}{lrrrrrr}
\hline & 1992 & 1993 & 1994 & 1995 & 1996 & 1997 \\
\hline Total & 2,471 & 2,967 & 3,186 & 4,088 & 4,645 & 5,161 \\
Machinery and equipment & 1,606 & 2,056 & 2,192 & 2,986 & 3,415 & 3,901 \\
& & & & & & \\
Textiles industry & 56 & 46 & 33 & 39 & 26 & 27 \\
Mechanical industry & 34 & 48 & 36 & 34 & 37 & 22 \\
Wood and furniture industry & 19 & 40 & 19 & 35 & 40 & 28 \\
& & & & & & \\
Telecommunications & 70 & 90 & 73 & 86 & 116 & 170 \\
Loading-unloading & 81 & 133 & 131 & 247 & 192 & 254 \\
Earth moving & 166 & 178 & 188 & 271 & 350 & 323 \\
& & & & & & \\
Generators, motors, and & & & & & & \\
$\quad$ transformers & 73 & 154 & 141 & 163 & 159 & 209 \\
Computers & 171 & 199 & 237 & 320 & 369 & 451 \\
Pumps and compressors & 46 & 63 & 56 & 74 & 71 & 91 \\
Others & 891 & 1,106 & 1,279 & 1,717 & 2,055 & 2,326 \\
Transportation & & & & & & \\
Goods & 865 & 911 & 995 & 1,102 & 1,231 & 1,260 \\
Automobiles & 234 & 215 & 190 & 336 & 334 & 357 \\
Tractors & 113 & 138 & 148 & 133 & 142 & 175 \\
Ships & 42 & 31 & 28 & 32 & 40 & 32 \\
Other & 45 & 67 & 84 & 101 & 13,0 & 57 \\
& & 459 & 545 & 501 & 585 & 639 \\
\hline & & & & & & \\
\hline
\end{tabular}

Source: Central Bank of Chile. 
Table 33. Chile: Direction of Trade

\begin{tabular}{|c|c|c|c|c|c|c|c|}
\hline \multicolumn{8}{|c|}{ (In percent) } \\
\hline & \multirow[b]{2}{*}{1993} & \multirow[b]{2}{*}{1994} & \multirow[b]{2}{*}{1995} & \multirow[b]{2}{*}{1996} & \multirow[b]{2}{*}{1997} & \multicolumn{2}{|c|}{$\frac{\text { Jan.-Sep. }}{1000}$} \\
\hline & & & & & & 1997 & 1998 \\
\hline Exports & 100.0 & 100.0 & 100.0 & 100.0 & 100.0 & 100.0 & 100.0 \\
\hline Europe & 28.0 & 25.3 & 29.4 & 25.9 & 25.7 & 24.9 & 28.7 \\
\hline European Union & 26.0 & 23.3 & 27.1 & 23.9 & 24.0 & 23.5 & 27.4 \\
\hline Belgium and Luxembourg & 1.4 & 1.8 & 2.4 & 1.6 & 1.6 & 1.6 & 2.5 \\
\hline France & 4.0 & 3.5 & 3.1 & 2.6 & 2.7 & 2.7 & 2.9 \\
\hline Germany & 5.2 & 5.0 & 5.1 & 4.8 & 4.4 & 4.0 & 3.5 \\
\hline Italy & 3.5 & 3.1 & 3.7 & 3.1 & 2.9 & 2.7 & 4.0 \\
\hline Netherlands & 2.8 & 3.0 & 2.7 & 2.6 & 2.5 & 2.8 & 3.0 \\
\hline Spain & 2.6 & 1.9 & 1.9 & 1.8 & 2.0 & 1.9 & 1.9 \\
\hline Sweden & 0.7 & 0.6 & 0.5 & 0.5 & 0.6 & 0.6 & 0.6 \\
\hline United Kingdom & 5.9 & 4.5 & 6.5 & 5.8 & 6.2 & 5.9 & 7.6 \\
\hline Other $1 /$ & 0.7 & 0.7 & 1.1 & 1.2 & 1.1 & 1.3 & 1.3 \\
\hline Other & 1.4 & 1.4 & 1.8 & 1.5 & 1.0 & 0.8 & 0.7 \\
\hline Western Hemisphere & 38.0 & 38.9 & 33.8 & 37.3 & 37.2 & 36.5 & 41.2 \\
\hline Canada & 0.6 & 0.6 & 0.6 & 0.9 & 0.8 & 0.6 & 1.0 \\
\hline LAIA countries & 19.0 & 20.1 & 18.2 & 18.9 & 19.7 & 18.6 & 21.9 \\
\hline Andean Pact countries $2 /$ & 6.0 & 6.6 & 6.6 & 6.6 & 6.6 & 6.1 & 7.8 \\
\hline Argentina & 6.3 & 5.5 & 3.6 & 4.6 & 4.6 & 4.3 & 4.9 \\
\hline Brazil & 4.3 & 5.2 & 6.4 & 6.1 & 5.6 & 5.4 & 5.1 \\
\hline Mexico & 1.4 & 1.8 & 0.8 & 1.0 & 2.2 & 2.1 & 3.3 \\
\hline Other & 1.0 & 0.9 & 0.7 & 0.8 & 0.7 & 0.7 & 0.8 \\
\hline United States & 17.6 & 17.3 & 14.4 & 16.6 & 15.9 & 16.4 & 17.3 \\
\hline Other & 0.8 & 0.9 & 0.6 & 0.9 & 0.8 & 1.0 & 1.1 \\
\hline Rest of the world & 34.0 & 35.8 & 36.7 & 36.8 & 37.0 & 38.6 & 30.1 \\
\hline China, People's Republic of & 1.9 & 1.1 & 1.8 & 2.3 & 3.5 & 3.7 & 4.3 \\
\hline Japan & 16.0 & 17.0 & 17.7 & 16.2 & 15.7 & 16.1 & 13.4 \\
\hline South Korea & & & 5.5 & 5.6 & 5.8 & 6.2 & 2.9 \\
\hline Taiwan & & & 4.3 & 4.1 & 4.6 & 4.7 & 3.8 \\
\hline Other & 16.1 & 17.7 & 17.3 & 18.2 & 17.8 & 18.8 & 12.3 \\
\hline Imports 3/ & 100.0 & 100.0 & 100.0 & 100.0 & 100.0 & 100.0 & 100.0 \\
\hline Europe & 24.2 & 23.3 & 22.2 & 22.4 & 22.4 & 22.2 & 22.9 \\
\hline European Union & 19.6 & 19.2 & 20.5 & 20.4 & 21.0 & 20.7 & 21.2 \\
\hline Belgium and Luxembourg & 1.0 & 1.0 & 0.8 & 0.8 & 0.7 & 0.7 & 0.7 \\
\hline France & 3.2 & 3.2 & 2.9 & 3.4 & 2.7 & 2.7 & 3.7 \\
\hline Germany & 5.8 & 4.9 & 5.1 & 4.2 & 4.5 & 4.5 & 4.1 \\
\hline Italy & 3.2 & 3.1 & 3.3 & 3.2 & 3.7 & 3.7 & 3.9 \\
\hline Spain & 2.6 & 3.0 & 2.9 & 3.1 & 3.3 & 3.3 & 3.7 \\
\hline Sweden & 1.1 & 1.1 & 1.3 & 1.6 & 1.9 & 1.3 & 1.4 \\
\hline United Kingdom & 2.0 & 2.2 & 1.6 & 1.7 & 1.7 & 1.7 & 1.5 \\
\hline Other $1 /$ & 0.4 & 0.5 & 2.6 & 2.6 & 2.5 & 2.7 & 2.3 \\
\hline Switzerland & 1.0 & 1.0 & 0.8 & 0.7 & 0.6 & 0.7 & 0.6 \\
\hline Other & 2.5 & 2.0 & 0.9 & 1.3 & 0.8 & 0.8 & 1.1 \\
\hline Western Hemisphere & 48.3 & 51.7 & 53.4 & 53.8 & 53.4 & 54.2 & 52.9 \\
\hline Canada & 1.9 & 2.3 & 2.0 & 2.4 & 2.3 & 1.7 & 2.7 \\
\hline LAIA countries & 22.8 & 25.5 & 26.2 & 26.8 & 27.5 & 27.3 & 26.6 \\
\hline Venezuela & 1.3 & 1.2 & 1.5 & 1.8 & 1.4 & 1.6 & 1.2 \\
\hline Other Andean Pact countries $2 /$ & 2.9 & 3.8 & 3.5 & 3.5 & 3.4 & 3.6 & 2.6 \\
\hline Argentina & 5.5 & 8.5 & 9.0 & 9.4 & 9.7 & 9.4 & 10.5 \\
\hline Brazil & 10.0 & 8.9 & 7.8 & 6.1 & 6.6 & 6.3 & 6.3 \\
\hline Mexico & 2.0 & 2.3 & 3.9 & 5.3 & 5.7 & 5.8 & 5.2 \\
\hline Other & 1.1 & 0.9 & 0.6 & 0.7 & 0.6 & 0.6 & 0.8 \\
\hline United States & 23.3 & 23.4 & 24.7 & 23.7 & 22.9 & 24.1 & 22.9 \\
\hline Other & 0.3 & 0.5 & 0.5 & 0.9 & 0.7 & 1.1 & 0.7 \\
\hline Rest of the world & 27.6 & 25.0 & 24.4 & 23.8 & 24.2 & 23.6 & 24.2 \\
\hline China, People's Republic of & 2.0 & 2.5 & 2.6 & 3.0 & 3.1 & 3.0 & 3.2 \\
\hline Japan & 8.3 & 8.9 & 6.6 & 5.5 & 5.6 & 5.1 & 6.0 \\
\hline South Korea & 3.2 & 3.0 & 3.4 & 3.2 & 3.1 & 3.0 & 3.2 \\
\hline \multicolumn{8}{|l|}{ Taiwan } \\
\hline Other & 14.0 & 10.6 & 11.8 & 12.1 & 12.4 & 12.6 & 11.8 \\
\hline
\end{tabular}

Source: Central Bank of Chile.

1/ Austria, Denmark, Finland, Greece, Ireland, and Portugal as of 1995.

$2 /$ Bolivia, Colombia, Ecuador, Peru, and Venezuela.

3/ Excludes imports through Free Trade Zones. 
Table 34. Chile: Net International Reserves of the Financial System (In millions of U.S. dollars)

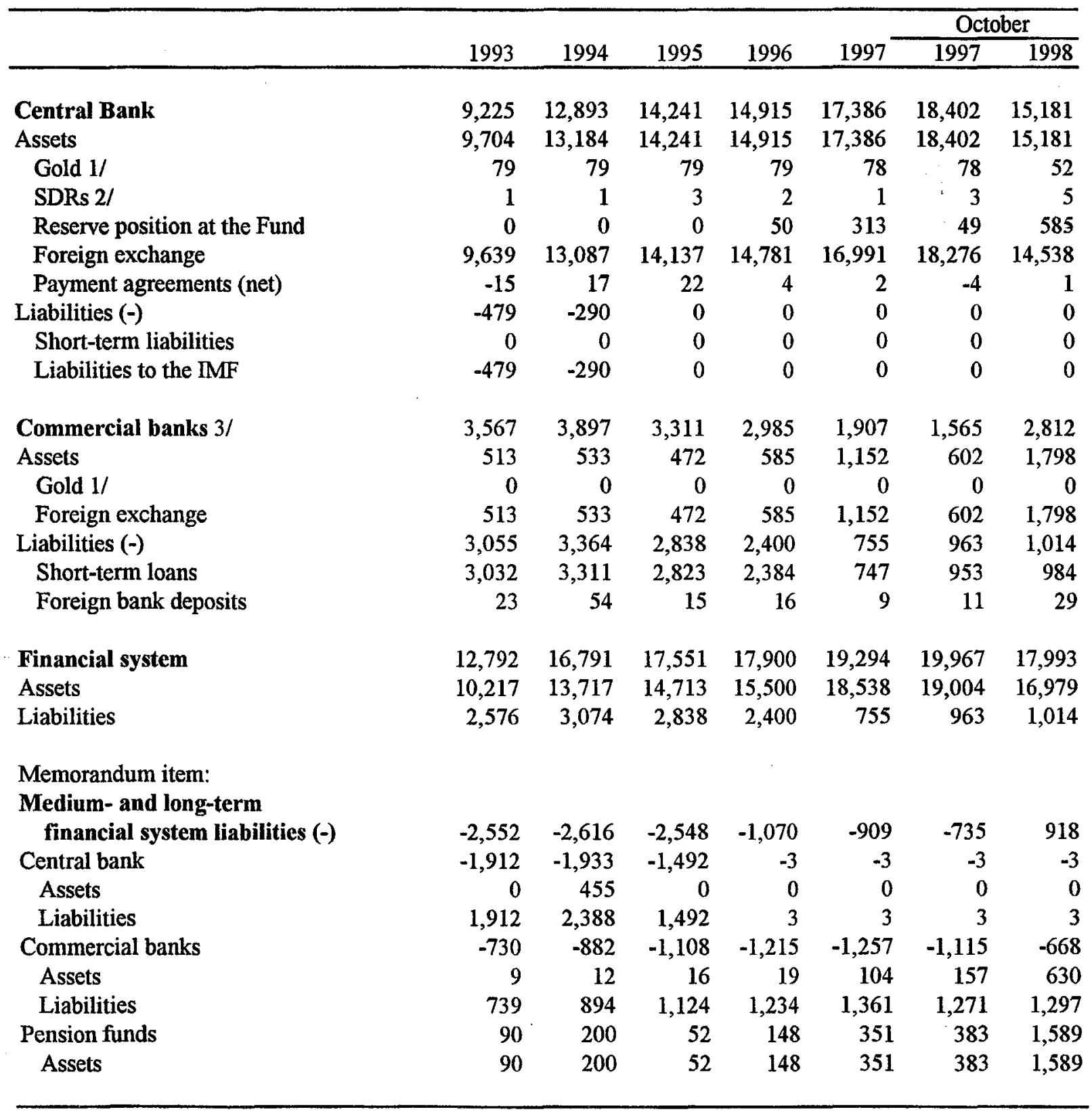

Sources: Central Bank of Chile; and Fund staff estimates.

1/ Valued at US $\$ 42.22$ per ounce; valued at market price the gold held by the Central Bank at end-October 19 was worth US\$317.5 million, and that of commercial banks US\$1.4 million.

2/ SDRs are valued at end-of-period rates with respect to the U.S. dollar.

3/ Includes Banco del Estado . 